\title{
The Impact of Augmented Reality for Displaying Virtual 3d Models of Products in Real Environments on Improvement of the Consumer Experience in Buying Industrial Designed Products
}

\author{
Elena Atanasova Paneva*, Sofija Sidorenko
}

Faculty of Mechanical Engineering, Industrial Design, Ss "Cyril and Methodius" University of Skopje, Skopje, Republic of Macedonia \begin{abstract}
Citation: Atanasova Paneva E, Sidorenko S. The Impact
of Augmented Reality for Displaying Virtual $3 d$ Models of Products in Real Environments on Improvement of the Consumer Experience in Buying Industrial Designed Products. SEE J Archit Des. 2019 Dec 27; 10044:1-129. https://doi.org/10.3889/seejad.2019.1004

Keywords: Augmented reality; AR technology; Online sales; 3D models; Online stores

Correspondence: Elena Atanasova Paneva. Faculty of Mechanical Engineering, Industrial Design, Ss "Cyril and Methodius" University of Skopje, Skopje, Republic o Macedonia. E-mail: atanasova.elena@hotmail.com Received: 25-Nov-2019; Revised: 25-Dec-2019; Accepted: 26-Dec-2019; Online first: 27-Dec-2019

Copyright: ๑ 2019 Elena Atanasova Paneva, Sofija is is an open-access article distributed und the terms of the Creative Commons AttributionNonCommercial 4.0 International License (CC BY-NC 4.0). Funding: This research did not receive any financial

Competing Interests: The authors have declared that no competing interests exist.
\end{abstract}

\section{Abstract}

The purpose of this paper is to explore the possibilities for implementation of the augmented reality (AR) in the sales. The augmented reality contributes to enhansing and improving the consumer experience through the virtual display of 3D models of products in realistic environments. In this paper is presented an overview of the consumer behavior in online shopping and their uncertainties in the process. The online shopping offers more satisfaction to the modern consumers looking for comfort and speed. On the other hand, some consumers still feel uncomfortable to shop online. What prevents them from buying online is the inability to realistically check the products, to examine their different variants, and to show them to their friends from which they will get comments and opinions before the purchase.

In this thesis are examined the possibilities for implementation of augmented reality technology in online stores, as well as the possibilities for management of the product configurations in AR - options for choosing different materials and colors of the product, that will allow the customers to adjust the product to their needs. The aim is to find methods and techniques that would alleviate the disadvantages as result of the lack of physical contact with the products during online sales, that would reduce the consumer uncertainty and increase the likelihood of successful choice and increased online sales.

The necessary adjustments that need to be done to the 3D models of the products in order to be successfully implemented in augmented reality are analysed, which will result in realistic display of the products. The augmented reality technology has been implemented by creating an online furniture store, where the products were available in augmented reality. Then, through a customer survey, the effect that the AR technology has on the online shoppers was examined, to determine whether it reduces the uncertainty in the online shopping decision making and increases the online sales. 
Универзитет „Св. Кирил и Методиј“ - Скопје

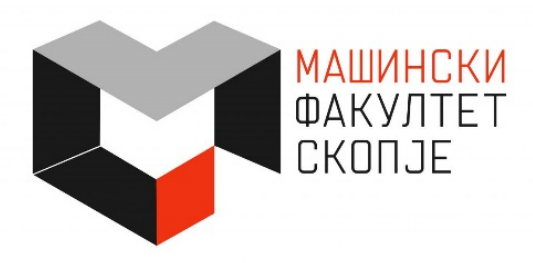

Машински Факултет - Скопје

Постдипломски студии

Втор циклус двегодишни студии

\title{
ЕЛЕНА АТАНАСОВА ПАНЕВА
}

Влијание на технологијата на аугментирана реалност за виртуелен приказ на 3Д модели на производи во реални средини врз подобрување на искуството на потрошувачите при купување на индустриски дизајнирани производи

\author{
МАГИСТЕРСКА РАБОТА
}

Ментор:

Проф.др. Татјана Кандикјан

СКОПЈЕ, 2019 
Ментор:

Проф.др. Татјана Кандикјан

Машински факултет - Скопје

Членови на комисијата:

Проф.др. Татјана Кандикјан

Машински факултет - Скопје

Проф. д-р. Ташко Ризов

Машински факултет - Скопје

Проф. д-р Софија Сидоренко

Машински факултет - Скопје

Дата на одбрана:

19.09.2019

Дата на промоција:

19.09.2019

ИНДУСТРИСКИ ДИЗАЈН И МАРКЕТИНГ

ЕЛЕНА АТАНАСОВА ПАНЕВА 
ВЛИЈАНИЕ НА ТЕХНОЛОГИЈАТА НА АУГМЕНТИРАНА РЕАЛНОСТ ЗА ВИРТУЕЛЕН ПРИКАЗ НА ЗД МОДЕЛИ НА ПРОИЗВОДИ ВО РЕАЛНИ СРЕДИНИ ВРЗ ПОДОБРУВАҢЕ НА ИСКУСТВОТО НА ПОТРОШУВАЧИТЕ ПРИ КУПУВАҢЕ НА ИНДУСТРИСКИ ДИЗАЈНИРАНИ ПРОИЗВОДИ

АПСТРАКТ: Целта на овој труд е да ги истражи можностите за примена на аугментираната реалност во продажбата. Аугментираната реалност преку виртуелен приказ на ЗД модели на производи во реални средини придонесува кон збогатување и подобрување на искуството на потрошувачите. Во овој труд се истражува однесувањето на потрошувачите при онлајн купувањето и нивните несигурности во процесот. Купувањето онлајн нуди поголемо задоволство кај современите потрошувачи кои бараат удобност и брзина. Од друга страна, некои потрошувачи сѐ уште се чуствуваат несигурно да купуваат онлајн. Тоа што ги спречува да купуваат онлајн е недостатокот на доверба и неможноста пореално да ги согледаат производите, да ги испитаат варијантите во кои се достапни, како и да ги покажат на своите пријатели од кои ќе добијат коментари пред купувањето.

Во овој труд ќе се истражуваат можностите за имплементирање на технологијата на аугментирана реалност во онлајн продавниците, како и достапните опции за управувањето со конфигурациите на производите во $\mathrm{AP}$, односно избор на различни материјали и бои, со кои производот би се прилагодил според желбите на потрошувачот. Со оваа технологија потрошувачите ќе можат виртуелно, преку својот смартфон да ги постават производите на одбраното место во домот и да проверат дали им одговараат. Целта е да се придонесе кон изнаоѓање на методи и техники со кои би се ублажиле недостатоците кои произлегуваат од недостатокот на физички контакт со производот во онлајн продажбата.

Анализирани се и неопходните прилагодувања кои треба да се направат на ЗД моделите на производите, со цел нивно успешно имплементирање во аугментирана реалност и реален приказ. Во овој труд, технологијата за аугментирана реалност е применета практично преку изработка на онлајн продавница за мебел. Потоа, ефектот кој оваа технологија го има врз онлајн купувачите е испитан преку анкета на корисници, со цел да се испита дали примената на АР влијае врз намалување на несигурноста при донесување на одлука за онлајн купување и врз зголемување на онлајн продажбите.

КЛУЧНИ Аугментирана реалност, АР технологија, онлајн продажба, ЗД модели, ЗБОРОВИ: онлајн продавници 


\section{ELENA ATANASOVA PANEVA}

THE IMPACT OF AUGMENTED REALITY FOR DISPLAYING VIRTUAL 3D MODELS OF PRODUCTS IN REAL ENVIRONMENTS ON IMPROVEMENT OF THE CONSUMER EXPERIENCE IN BUYING INDUSTRIAL DESIGNED PRODUCTS

ABSTRACT: The purpose of this paper is to explore the possibilities for implementation of the augmented reality (AR) in the sales. The augmented reality contributes to enhansing and improving the consumer experience through the virtual display of $3 \mathrm{D}$ models of products in realistic environments. In this paper is presented an overview of the consumer behavior in online shopping and their uncertainties in the process. The online shopping offers more satisfaction to the modern consumers looking for comfort and speed. On the other hand, some consumers still feel uncomfortable to shop online. What prevents them from buying online is the inability to realistically check the products, to examine their different variants, and to show them to their friends from which they will get comments and opinions before the purchase.

In this thesis are examined the possibilities for implementation of augmented reality technology in online stores, as well as the possibilities for management of the product configurations in AR - options for choosing different materials and colors of the product, that will allow the customers to adjust the product to their needs. The aim is to find methods and techniques that would alleviate the disadvantages as result of the lack of physical contact with the products during online sales, that would reduce the consumer uncertainty and increase the likelihood of successful choice and increased online sales.

The necessary adjustments that need to be done to the 3D models of the products in order to be successfully implemented in augmented reality are analysed, which will result in realistic display of the products. The augmented reality technology has been implemented by creating an online furniture store, where the products were available in augmented reality. Then, through a customer survey, the effect that the AR technology has on the online shoppers was examined, to determine whether it reduces the uncertainty in the online shopping decision making and increases the online sales.

KEYWORDS: Augmented reality; AR technology; Online sales; 3D models; Online 
stores

\section{Содржина}

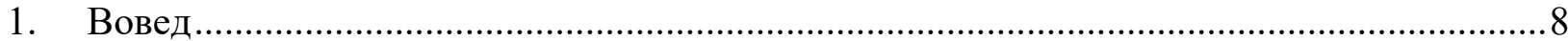

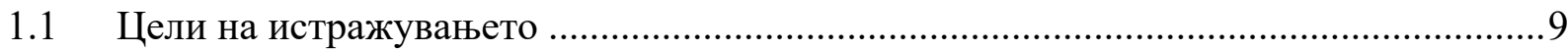

1.2 Методологија на истражување ...................................................................... 10

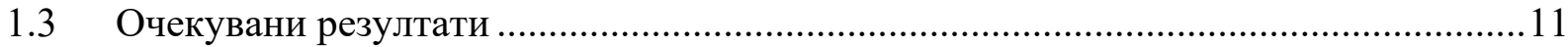

2. Краток осврт на онлајн продажбата .................................................................... 12

2.1 Краток осврт на онлајн продажбата во светот .................................................. 12

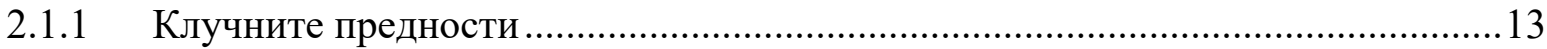

2.1.2 Очекуван мобилен платежен бум, управуван од м-трговијата .......................13

2.2 Краток осврт на онлајн продажбата во Р.С. Македонија ........................................ 14

3. Процес на донесување одлука за купување ............................................................... 16

3.1 Влијанија врз донесување на одлука за купување онлајн .................................... 18

3.1.1 Мотивации за онлајн купување.................................................................. 18

3.1.2 Фактори кои ги попречуваат потрошувачите да купуваат онлајн....................20

4. Потребни карактеристики на веб-сајт соодветен за онлајн купување .........................22

4.1 Доверлив и безбеден веб-сајт ........................................................................22

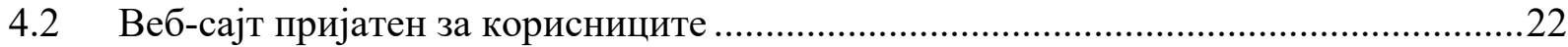

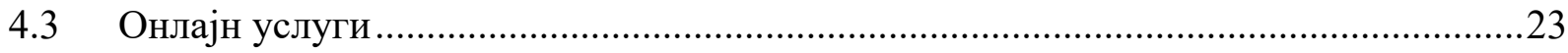

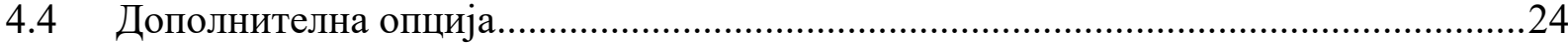

5. Имплементирање на аугментираната реалност во продажбата .................................25

5.1 Потребата од технологијата на аугментирана реалност во онлајн купувањето .....25

5.2 Историјат на аугментираната реалност ….......................................................26

5.3 Компоненти на мобилни АР системи (МАРС) …...............................................28

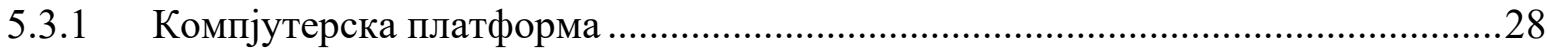

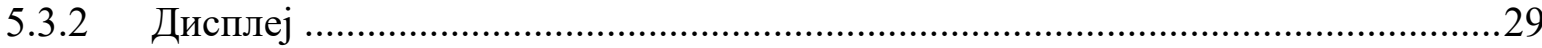

5.3.3 Регистрација на реалната околина ...............................................................29

5.3.4 Преносни влезни и интеракциски технологии ............................................29 


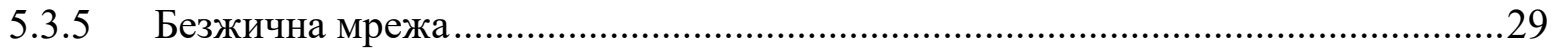

5.3.6 Складирање на податоците и технологија за пристап .....................................29

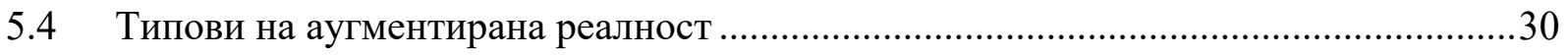

5.4.1 Статични системи за аугментирана реалност .............................................30

5.4.2 Просторни системи за аугментирана реалност..............................................30

5.4 .3 Десктоп аугментирана реалност ....................................................................30

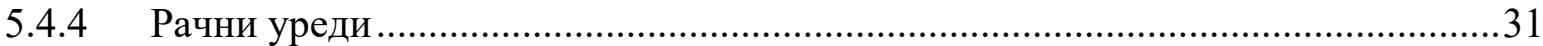

5.4.5 Дисплеи кои се поставуваат на глава …..........................................................31

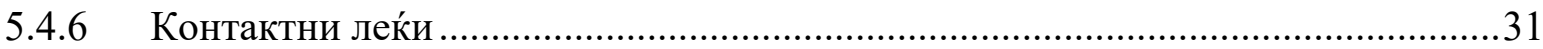

5.4.7 Аугментирана реалност базирана на визија...............................................3

5.4.8 Аугментирана реалност базирана на локација .............................................32

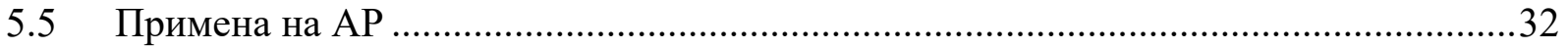

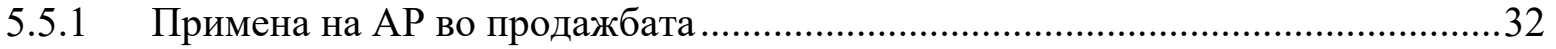

5.5.2 Примена на АР во производство и одржување...............................................33

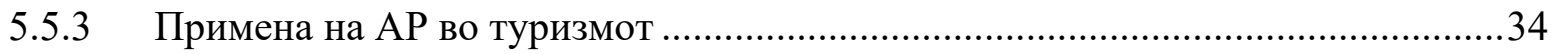

5.5.4 Примена на АР во маркетинг и рекламирањето ...............................................35

5.6 Аугментираната реалност во продажбата ..........................................................36

5.6.1 Примена на аугментираната реалност во традиционалната продажба ............39

5.6.2 Примена на аугментираната реалност во онлајн продажбата........................42

5.7 Прифаќањето на АР технологијата од потрошувачите .........................................43

5.8 Анализа на потребните модули на АР систем во онлајн продажбата ....................45

5.8.1 Предности во однос на традиционалниот систем …......................................47

6. Софтверски решенија за примена на аугментираната реалност во малопродажбата...49

6.1 Прифатливи 3Д формати за Аугмент................................................................50

6.2 Повеќе информации за 3Д моделот за прикачување во Augment ...........................51

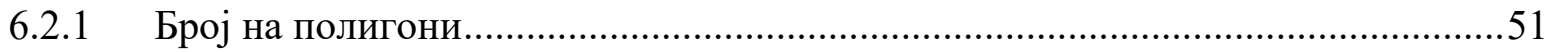

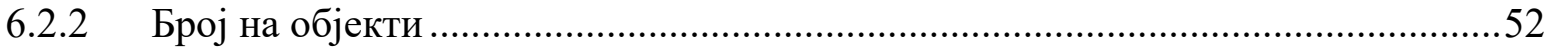

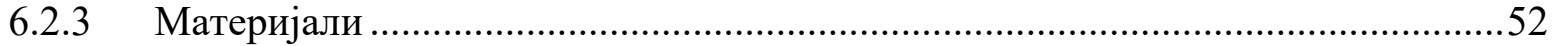

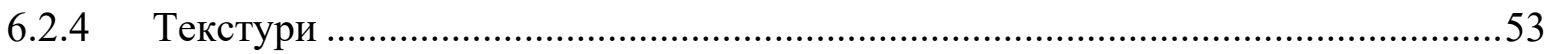

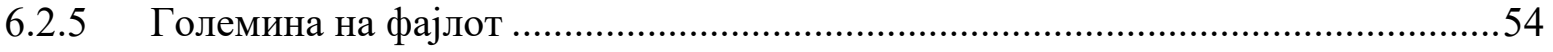

6.3 Имплементирање на Solidworks 3Д модели во Augment .......................................54 


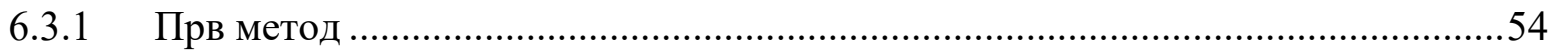

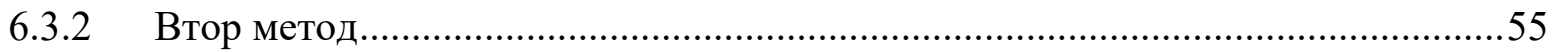

6.4 Прилагодување на 3Д моделите за аугментирана реалност преку Augment Desktop

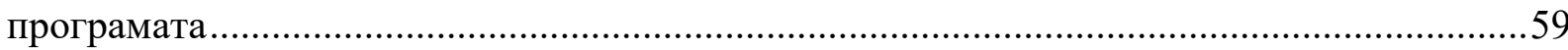

7. Развој на веб-сајт за малопродажба со модул за аугментирана реалност.......................71

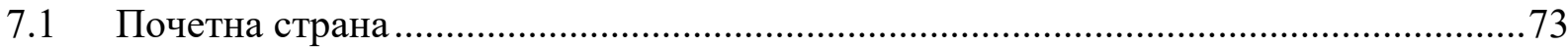

7.1.1 Пробајте ги производите во вашиот дом со аугментирана реалност …….........74

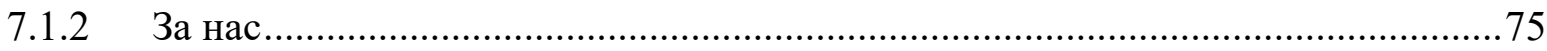

7.1.3 Подножје на веб-сајтот (Footer) …………......................................................

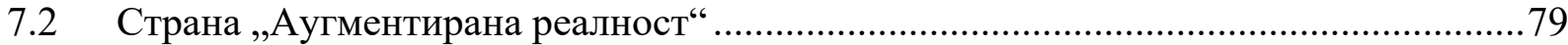

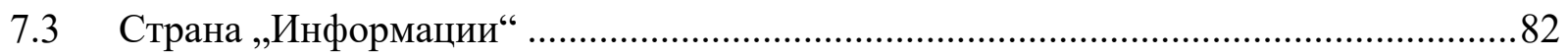

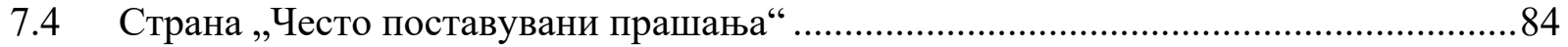

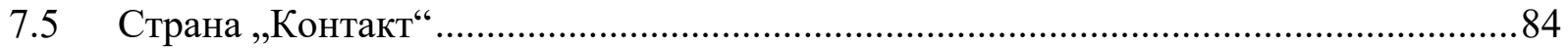

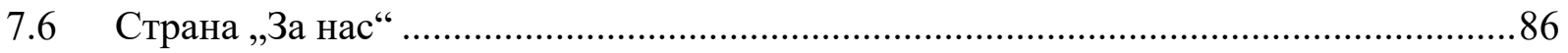

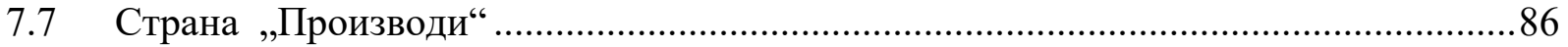

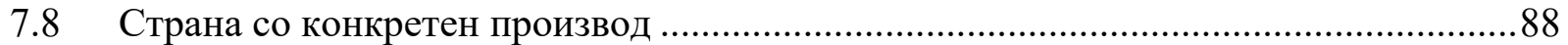

7.8.1 Поле „Информации за испорака и враќање на производите“ на страната со конкретен производ .......................................................................................................8

7.8.2 Поле „Аугментирана реалност“ на страната со конкретен производ ...............8

8. Пренос и прикажување на CAD модели на производи во аугментирана реалност со

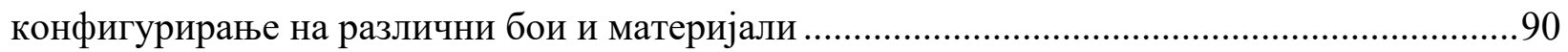

8.1 Отворање на производот во аугментирана реалност..................................................90

8.2 Поставување на производот на саканото место во домот..........................................91

8.3 Промена на боја или материјал на производот ………………………………….....91

8.4 Сликање на производот во аугментирана реалност ……………………………......92

9. Анализа на искуствата при купување со вградена аугментираната реалност и

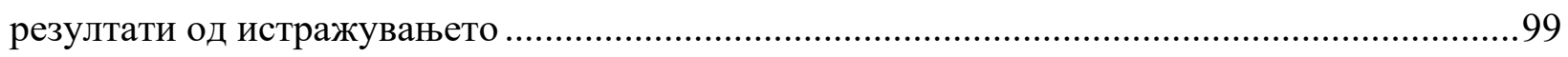

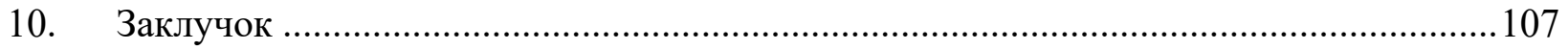

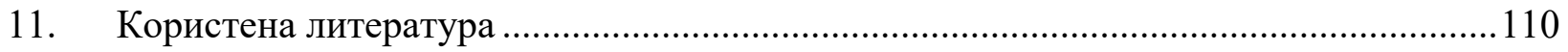

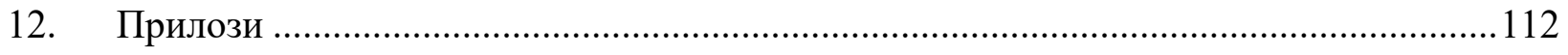

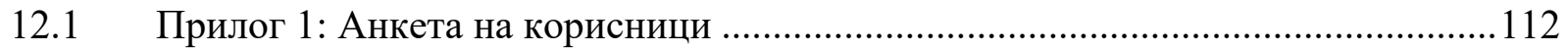

12.2 Прилог 2 : Графички приказ на резултатите од анкетата.......................................115 
12.3 Прилог 3: Приказ на прилагодениот веб-сајт за потребите на Машински факултет.

\section{1. Вовед}

Во оваа магистерска работа ќе се истражи погодноста на новите технологии на аугментирана реалност за подобрување на визуелното разбирање на купувачите при онлајн претставувањето на производите, кои се конципирани да можат да се прилагодуваат на различните барањата на купувачите. Новата технологија на аугментирана реалност, која овозможува виртуелен приказ на $3 Д$ модели на производи во реални средини треба да придонесе кон збогатување и подобрување на искуството на потрошувачите, пред се преку можноста да се пробаат повеќе производи и повеќе варијанти на производите на самото место каде ќе бидат поставени по купувањето и со тоа да се намали несигурноста при изборот.

Купувањето на интернет веќе е широко прифатен начин за купување на производи и услуги. Потрошувачите купуваат онлајн затоа што им се нудат повеќе информации за производите, повеќе можности за споредување на производите и цените, поголем избор на производи, како и удобност на купување од својот дом и лесно пронаоѓање на бараните производи. Купувањето онлајн нуди поголемо задоволство кај современите потрошувачи кои бараат удобност и брзина. Од друга страна, некои потрошувачи сѐ уште се несигурни да купуваат онлајн. Тоа што ги спречува да купуваат онлајн е недостатокот на доверба и неможноста пореално да ги согледаат производите, да ги испитаат варијантите во кои се нудат, како и да ги покажат на своите пријатели од кои ќе добијат коментари пред купувањето, што негативно влијание врз одлуката за купување онлајн. Негативниот ефект е уште поголем при купувањето преку мобилен. Повеќе од 50\% од посетителите на продавниците за е-трговија доаѓаат од мобилен телефон, но за жал конверзиите, односно процентот на купувања преку мобилен телефон е сеуште значително помал во однос на продажбите преку компјутер.

Во оваа магистерска работа ќе се истражат ефектите и можностите на технологијата на аугментирана реалност за пореалистично претставување на производите во реалната околина во која ќе се користат, како и управувањето со конфигурациите на производот, односно изборот на материјали и бои со кои се прилагодува производот по мерка на потрошувачот. Целта е да се изнајдат методи и техники со кои би се ублажиле недостатоците кои произлегуваат од недостатокот на физички контакт со производот, со што би се намалила несигурноста кај потрошувачите и би се зголемила веројатноста за успешен избор и онлајн купување. 
Технологијата на аугментирана реалност овозможува да се видат ЗД моделите на производите во реална големина во избрана околина, со примена на соодветно подготвен ЗД модел на производот.

За да се имплементира оваа технологија, дизајнерите треба да знаат како соодветно да ги подготват 3Д моделите на производите и да ги додадат параметрите за нивното конфигурирање според барањата на купувачите, за да може да се имплементираат на веб страната или мобилната апликација на онлајн продавачот.

Во овој труд ќе бидат анализирани и можностите за поширока апликација и примена на аугментираната реалност во визуелизација и презентацијата на производите.

Со цел подобро претставување на технологијата на аугментирана реалност во онлајн продажбата, ќе биде дизајнирана веб-страна за онлајн продажба на мебел. На веб-страната освен стандардни неопходни информации и слики, ќе биде имплементирана и аугментираната реалност и опцијата за промена на боја и материјал на производите, со што потрошувачите пред купување, ќе можат да ги погледнат производите како би изгледале во реални димензии, во реална околина на местото каде што би се користеле, со цел да одлучат дали се соодветни да ги купат.

Во овој труд ќе биде направено и истражување на потрошувачите со цел да се оцени искуството на потрошувачите со аугментираната реалност при онлајн купувањето, преку користење на сајтот кој ќе биде изработен за оваа намена, како и да се испита дали аугментираната реалност влијае врз намалување на несигурноста при онлајн купување и зголемување на онлајн продажбите.

\section{1 Цели на истражувањето}

Овој магистерски труд има за цел да придонесе кон подобро визуелно и содржинско разбирање на дизајнираните производи при нивно претставување онлајн и подобро да се задоволат различните барања и потреби на клиентите, што ќе резултира во нивно поголемо задоволство и зголемена продажба на производите. Поширока цел е да се доближи новата и напредна технологијата на аугментирана реалност до онлајн продавниците, со цел да се зголеми комерцијалната употреба на 3 Д модели на дизајнирани производи.

Некои од конкретните цели на оваа магистерска работа вклучуваат:

- $\quad$ Проучување на процесот на онлајн продажба и на најновите технологии и трендови во истата, вклучувајќи ја и аугментираната реалност. 
- $\quad$ Осознавање на несигурностите кои потрошувачите ги имаат при оналјн купувањето и предлагање на начини за нивно надминување

- Анализа на достапната технологија на аугментирана реалност, со цел нејзино подобро разбирање и примена. Утврдување на начини за нејзино имплементирање при онлајн и офлајн продажба. Утврдувања на подрачја за нејзина примена и можни ограничувања во примената.

- $\quad$ Дизајн на веб-сајт на која ќ бидат прикажани сите елементи кои потрошувачите сакаат да ги најдат на сајт за онлајн продажба и имплементирање на опцијата за приказ на ЗД модели на дизајнирани производи во аугментирана реалност. Ова ќе влијае врз намалување на несигурноста при онлајн купувањето.

- Истражување на ефектите од воведувањето на аугментираната реалност и осознавање во која мера може да го збогати искуството на потрошувачите, психолошкиот ефект врз нив, степенот на прифатеност и како влијае врз ставот на клиентите кон брендот.

\section{2 Методологија на истражување}

Подолу се наоѓаат методите на истражување кои ќе ги користам во магистерскиот труд:

I. Истражување и проучување на објавени трудови од областа на онлајн продажбата, мобилната продажба и најновите трендови во истите.

II. Истражување на причините за несигурност при онлајн купување и начини како да се надминат, преку проучување на објавени научни трудови

III. Анализа на достапната технологија за аугментираната реалност, како и начините за примена на аугментираната реалност преку истражување на постоечки примери на аугментираната реалност во онлајн и офлајн продажбата и проучување на објавени научни трудови на оваа тема.

IV. Дизајн на веб-сајт за презентација на производи според барањата на потрошувачите, со опција за гледање на производите во аугментирана реалност.

V. Проучување на прифаќањето на аугментираната реалност во продажбата од страна на потрошувачите, нивното искуство со истата, како и влијането кое таа го има врз донесување на одлука за купување онлајн. Истражувањето на мислењето на корисниците би се спровело со анкетирање на испитаници кои ке го користат сајтот за онлајн продажба на мебел кој ќе се изработи за оваа намена и на кој ќе можат да ги видат производите во 
аугментирана реалност. Ке се испита дали аугментираната реалност ја намалува несигурноста при разбирањето и восприемањето на производите, како и врз одлуката за избор на производот и купување.

\section{3 Очекувани резултати}

Со оваа магистерска работа очекувам да се пронајдат начини за намалување на несигурноста на потрошувачите при онлајн купување на производи, преку изнаоѓње на решение кое ќе им овозможи брз увид како различни производи би изгледале во околината во која треба да се користат по купувањето, преку прикажување на виртуелен 3Д модел на производ во реалната околина со примена на технологијата за аугментирана реалност. Очекувам технологијата за аугментираната реалност да го забрза и олесни визуелното разбирање на производите и пристапот до различни корисни информации за истите и да ги зголеми онлајн продажбите.

Преку нудење на повеќе опции за конфигурирање на производите во аугментирана реалност, целта е да се понудат доволно визуелни податоци за производите, со цел купувачите онлајн да ја донесат одлуката за купување на производот.

Во овој труд ќе се истражат предностите кои технологијата за аугментирана реалност им ги нуди на компаниите.

Оваа технологија очекувам да има позитивно влијание врз довербата на клиентите и намалување на несигурноста, што ќе резултира во зголемено задоволство кај купувачите и значително намален процент на вратени производи.

Очекуван резултат е и да се доближи технологијата на аугментираната реалност до онлајн и офлајн продавниците, како и до индустриските дизајнери во Р.С.Македонија, со цел да се започне со имплементација на аугментираната реалност во продажбата на производи. 


\section{2. Краток осврт на онлајн продажбата}

\section{1 Краток осврт на онлајн продажбата во светот}

Глобалната е-трговија од година во година расте драстично. Онлајн купувањето е се попопуларно, а бројот на глобални онлајн купувачи секојдневно расте. Во 2016 година, дури $53 \%$ од глобалните интернет корисници купиле нешто онлајн, што е скоро 1 милјарда интернет корисници. ${ }^{1} 65 \%$ од потрошувачите повеќе би сакале да купат глобално, отколку локално, доколку цената на производот е поповолна. Сеуште најзастапен уред за онлајн купување е компјутерот, опфаќајки $76,9 \%$ од онлајн продажбите, на второ место е таблетот со $12,4 \%$, додека на последно место и најмала е онлајн продажбата преку мобилен телефон - само $10,7 \%{ }^{2}$ Нискиот процент на онлајн продажби преку мобилен телефон е проблем на кој треба да се работи со цел негово отстранување, бидејќи мобилните уреди веќе се клучните платформи за дигитална содржина и комуникации, како резултат на големиот пораст на продажбата на смартфони која ќе достигне 2,05 милјарди до 2020 година. ${ }^{3}$

Според извештајот на Ovum - Иднината на е-трговијата: Патот до 2026 мобилните уреди веќе се клучна платформа за дигитални содржини и комуникации, а истото станува реалност и во малопродажниот и трговскиот домен. Ова е резултат на огромниот раст на продажбата на смартфони.

${ }^{1}$ Cohen. K. Global eCommerce Sales, Trends and Statistics 2016. 2017.

${ }^{2}$ Saleh K. Global Online Retail Spending - Statistics and Trends.2017

${ }^{3}$ Ovum report, The Future od E-commerce: The road to 2026, Vol 1, pp.9, 2016 


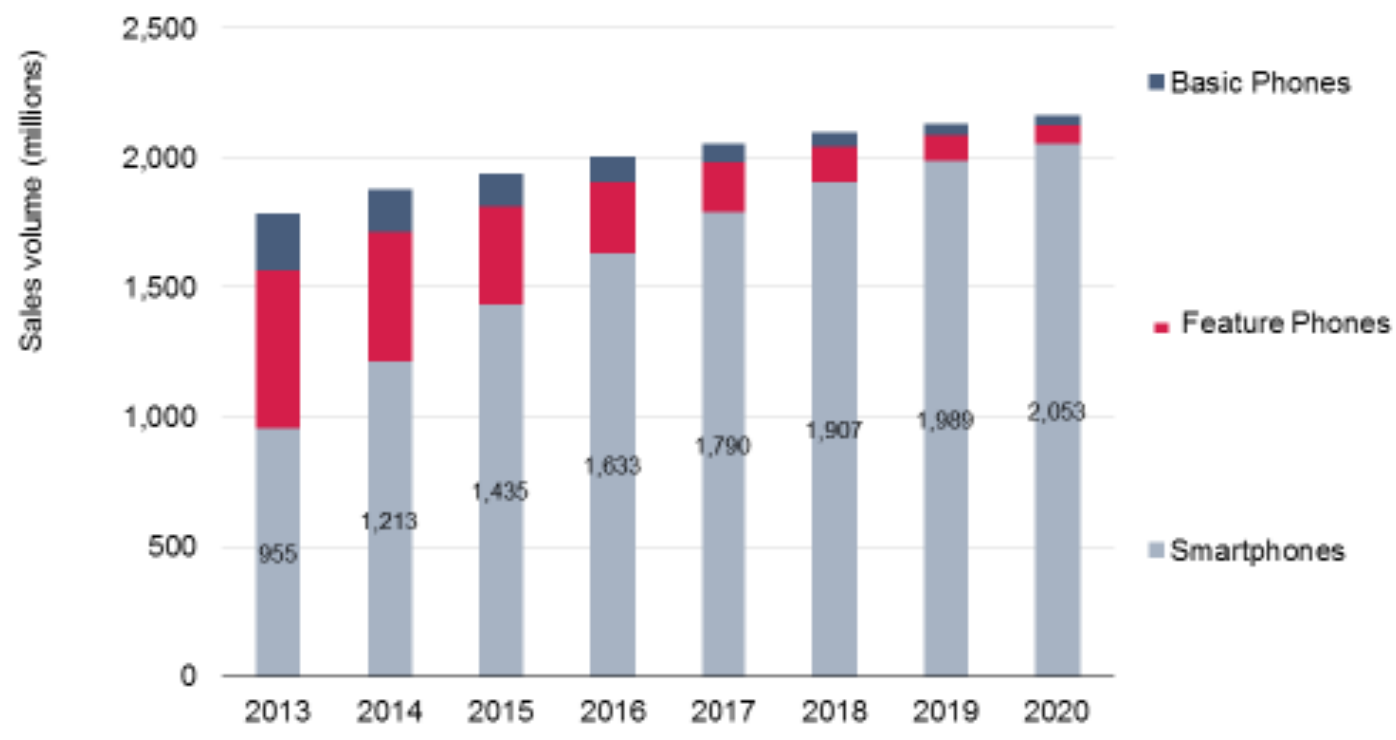

Слика 1 - Глобален обем на продажба на мобилни телефони - по сегмент

\subsection{1 Клучните предности}

Широко распространетото користење на моќни смартфони со поголеми екрани го подобрува искуството со мобилната трговија. Во меѓувреме, трговците на мало се повеќе ги оптимизираат своите сајтови за мобилен шопинг. Смартфонот се претвора во платформа која може целосно да го поддржува онлајн купувањето, од пребарување на производи, до споредби, препораки и онлајн плаќање.

\subsection{2 Очекуван мобилен платежен бум, управуван од м-трговијата}

Според извештајот на Ovum, се очекува многу силен раст во мобилните плаќања за онлајн купување на производи и услуги во текот на следните пет години. Очекуван е пораст на глобалните корисници на мобилно плаќање од околу 452.78 милиони во 2014 година на 2,07 милијарди корисници во 2019, како што е прикажано на сликата подолу. Овде мобилната трговија е дефинирана како С2В - од аспект потрошувач кон бизнис. Потрошувачите веќе се насочуваат кон паметни телефони и таблети за м-трговија, тренд кој забрзано ќе продолжи, како што корисничкото искуство ќе се подобрува. Покрај тоа, бројот и вредноста на трансакциите од м-трговија се повеќе растат во развиените пазари. М-трговијата станува најголем сегмент за м-плаќања од аспект на трансакциска вредност, 
која се очекува да порасне од 50,92 милијарди долари во 2014 година на 693,35 милијарди долари во 2019 година.

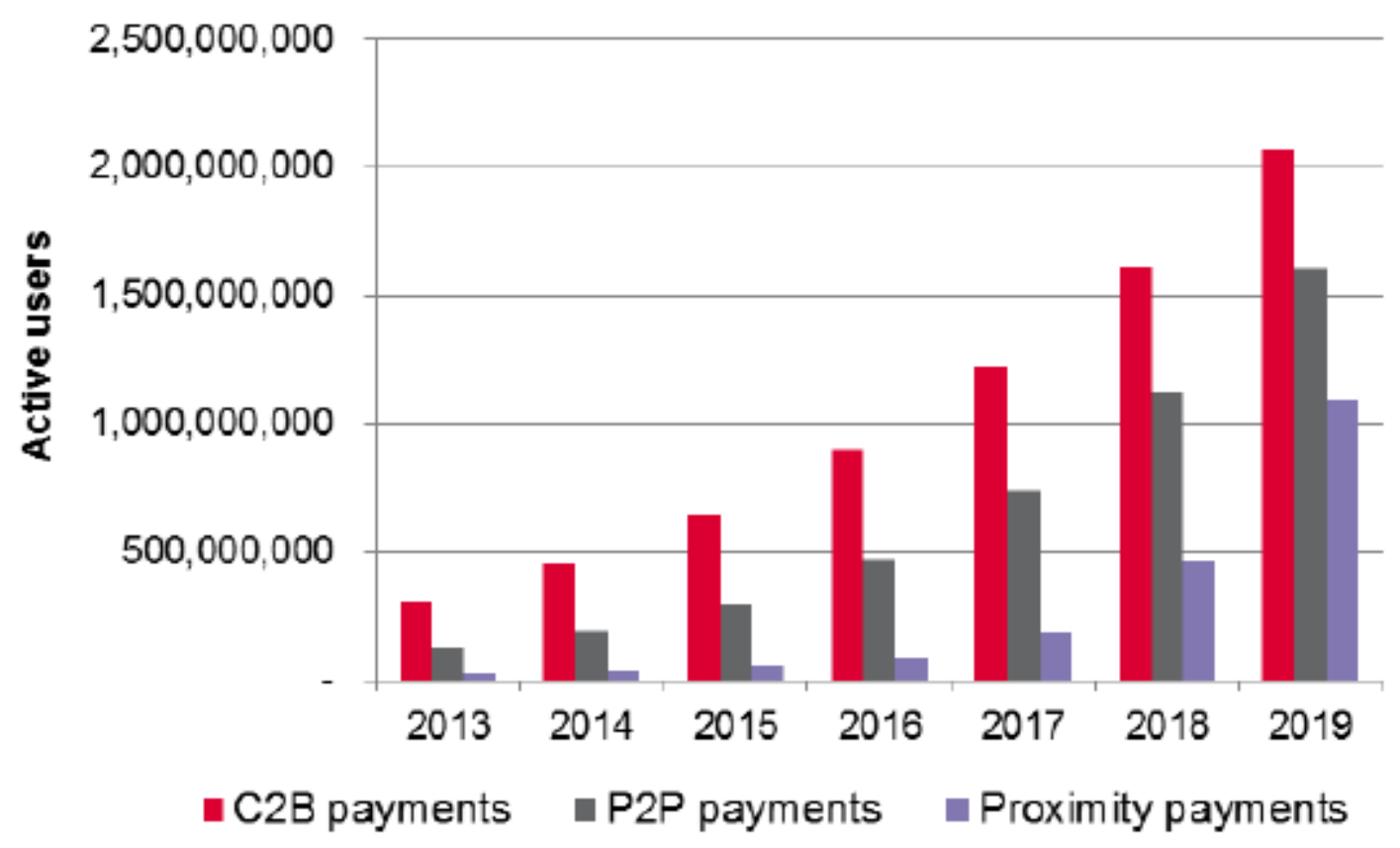

Слика 2 - Глобални корисници на м-плаќање - по сегмент

\section{2 Краток осврт на онлајн продажбата во Р.С. Македонија}

Според податоците на Државниот завод за статистика ${ }^{4}$ на Р.С.Македонија во првиот квартал од 2018 година 79.3 \% од домаќинствата имале пристап на интернет од дома.

Во истиот период, од вкупното население на возраст од 15 до 74 години, интернет користеле 79.2 \%, а 68.7 \% го користеле секој ден или речиси секој ден.

Најчесто користени уреди за пристапување на интернет се мобилен телефон - 68,8\%, следено од лаптоп 40,1\%, десктоп компјутер 36,5\%, таблет 14,0\% и други мобилни уреди co $1,5 \%$. Што значи дека најпопуларен уред за пристапување на интернет е убедливо мобилниот телефон. Ова особено е изразено кај лицата на возраст од 15 до 24 години, каде процентот на пристап на интернет од мобилен телефон изнесува $91.8 \%$.

4 Државен завод за статистика на Р.С.Македонија. Информатичко општество. Соопштение Број/No: 8.1.18.29: Користење информатичко- комуникациски технологии во домаќинствата и кај поединците, 2018 година. Октомври 2018 
Македонските корисници најмногу користат интернет за учество во социјалните мрежи (64,8\%), па за телефонирање преку интернет / видеоповици $(60,4 \%)$ и за наоѓање информации за производи/услуги 49,6\%. Потоа следат активности како слушање музика $(46,2 \%)$, користење на е-меил $(41,3 \%)$ и барање информации поврзани со здравјето $(39,6 \%)$. Останатите активности кои ги прават на интернет имаат значително помало учество.

Според податоците на Државниот завод за статистика, во Р.С. Македонија 31.6\% од населението нарачале/купиле производи или услуги преку интернет во последните 12 месеци. Мнозинството од нив (54.9 \%) купиле облека или спортска опрема, следено од производи за домаќинство (18\%) и електронска опрема $(16,9 \%)$.

Најголем број од интернет купувањата биле направени кон продавачи од земјата (52,3\%). Интернет купувањата од продавачи од земјите на ЕУ учествуваат со 18,8\%, од останатите земји од светот опфаќаат $36,2 \%$, додека само $3,4 \%$ од онлајн купувањата се од продавачи чија земја на потекло не е позната.

Од ова може да се заклучи дека скоро една третина од населението во Македонија нарачале/купиле производи или услуги преку интернет во последните 12 месеци. Повеќе од половина од нив купиле производи од Македонски продавачи, што е голема можност за македонските трговци да работат на зголемување на интернет продажбата.

Според Katawetawaraks и Lu Wang (2011) ${ }^{5}$ онлајн купувањето им нуди поголемо задоволство на модерните купувачи кои бараат удобност и брзина, од друга страна, некои потрошувачи сеуште не се чуствуваат удобно да купуваат онлајн. Недостатокот на доверба е една од главните причини која ги спречува потрошувачите да купуваат преку интернет. Некои од потрошувачите сакаат да ги проверат и почувствуваат производите, да им ги покажат на пријателите и да добијат коментари за истите пред да ги купат. Ваквите фактори имаат негативно влијание врз донесувањето на одлука за купување онлајн.

Токму технологијата на аугментираната реалност ги намалува овие негативни влијанија, преку виртуелен приказ на 3Д моделите на производите во реалните средини на потрошувачите. Со ова се оди на следното ниво - од само разгледување на производите во продавница, до нивен приказ во реалните средини на местото каде што ќе бидат поставени и ќе се користат. На овој начин, потенцијалните клиенти можат да проверат дали производите им одговараат, која боја и големина е најсоодветна, како и да се консултираат со пријателите и да се уверат дека го прават вистинскиот избор. Оваа технологија го олеснува донесувањето на одлука за купување онлајн и соодветно ги зголемува онлајн продажбите на производите.

\footnotetext{
${ }^{5}$ Katawetawaraks Ch., Wang Ch.L. Online Shopper Behavior: Influences of Online Shopping Decision, Asian Journal of Business Research, vol.7 no.2 pp. 67-69. 2011
} 
Интернет купувањето е нашироко прифатен начин за купување на производи и услуги, кое им овозможува на потрошувачите повеќе информации, поголем избор за споредба на производи и цени, поголема удобност и достапност. Онлајн купувањето овозможува поголемо задоволство за модерните купувачи кои бараат удобност и брзина.

\section{3. Процес на донесување одлука за купување}

Според Ch. Katawetawaraks и Ch. L. Wang процесот на донесување на одлука за купување е многу сличен во онлајн и офлајн продажбата. Некои од главните разлики е околината на купување и маркетинг комуникациите. Според традиционалниот модел за донесување на одлука за купување, донесувањето на одлука започнува со осознавање на потребата за купување, пребарување на информации за производите, оценување на алтернативи, донесување на одлука за купување и на крај, однесување пост-купување.

Во онлајн комуникациите, кога потрошувачите ќе видат реклами на банер или онлајн промоција, овие реклами може да го привлечат нивното вниманието и да стимулираат интерес за дадените производи.

Пред да се одлучат да купат, на потрошувачите ќе им бидат потребни дополнителни информации кои ќе им помогнат да се одлучат. Според Laudon и Traver (2009) ${ }^{6}$, доколку потрошувачите немаат доволно информации, ќе пребаруваат преку онлајн канали како веб страни, веб пребарувачи и онлајн каталози. Кога потрошувачите имаат доволно информации, ќе треба да ги споредат избраните производи или услуги. Во фазата на пребарување информации, потенцијалните купувачи можат да бараат повеќе слики, видеа или статии со рецензии на производот или коментари на корисниците.

На овој начин сакаат да откријат кој бренд или компанија им нуди најдобра понуда за нивните потреби. За време на оваа фаза, добро организираната структура на веб сајт и атрактивен дизајн се битни за привлекување на потрошувачите да се заинтересираат за купување на производот или услугата (Koo et al., 2008). Природата на изворот на информацијата може да влијае врз однесувањето на купувачот (Bigné-Alcañiz et al., 2008).

Најкорисна карактеристика на интернетот е тоа што ја поддржува фазата пред купување и им помага на потрошувачите да споредуваат различни опции. За време на купувањето, најбитните фактори кои им помагаат на потрошувачите да одлучат кој производ ќе го

\footnotetext{
${ }^{6}$ Laudon, K.C. and Traver, C.G., (2009), E-Commerce Business. Technology. Society, 5th edition, Prentice Hall, New Jersey
} 
одберат или од кој продавач да купат се: асортиманот на производите, продажните услуги и квалитетот на информациите (Koo et al., 2008) ${ }^{7}$.

Однесувањето по купувањето е многу важно за онлајн купувањето. Потрошувачите понекогаш имаат проблем или прашања за производот, или можеби сакаат да го сменат или вратат. Како резултат на ова, услугите за враќање и замена на производите стануваат се побитни во фазата на пост-купувањето.

Според Comegys (2009) сите фази опишани погоре се под влијание на екстерни фактори на ризик и доверба. Процесот на барање информации е значајна компонента во онлајн однесувањето на потрошувачите. Ризикот од изворот се појавува во фазата на барање информации и евалуација бидејќи информациите на веб страните можат да содржат некои грешки. Некои веб страни бараат потрошувачите да се регистрираат пред да ја пребаруваат нивната страна. На овие страни, освен ризикот од грешни информации за производот, потрошувачите се соочуваат со ризик за безбедноста на информациите (Comegys et al., 2009; Wang et al., 2005) ${ }^{8}$. Поради природата на онлајн купувањето, потрошувачите превземаат ризици со тоа што не се во можност да ги испитаат производите пред да ги купат. Исто така преземаат ризик и во процесот на плаќњето, бидејќ треба да остават приватни информации, како број на кредитна картичка. Проблемите со безбедноста не завршуваат во фазата на купување, туку продолжуваат и во пост-продажната фаза, бидејќи нивните лични податоци може да бидат искористени за друга намена.

Според Laudon и Traver $^{6}$ кога потрошувачите сакаат да купат производ, тие го гледаат брендот и карактеристиките на производот или услугата. Некои производи, како книги и софтвер можат едноставно да се купат и испорачаат онлајн, но од друга страна за некои производи е тешко да се донесе одлука онлајн. Опциите на веб страната, способностите на фирмата, маркетинг комуникациските стимули и вештините на клиентите се исто така битни според Laudon и Traver.

Според Prasad and Aryasri9 ${ }^{9}$ опциите на веб страната се една од битните работи кои можат да влијаат врз одлуката за онлајн купување. На пример, онлајн трговците можат да користат напредна технологија за да го подобрат нивниот веб сајт со цел да влијаат врз перцепциите на потрошувачите за веб околината.

\footnotetext{
${ }^{7}$ Koo, D.M., Kim, J.J. and Lee, S.H. "Personal values as underlying motives of shopping online", Asia Pacific Journal of Marketing and Logistics, vol. 20, no. 2, pp. 156-173. 2008

${ }^{8}$ Comegys, C., Hannula, M. and Váisánen, J. "Effects of consumer trust and risk on online purchase decision-making: A comparison of Finnish and United States students", International Journal of Management, vol. 26, no. 2, pp. 295-308. 2009

9 Prasad, C. and Aryasri, A. "Determinants of shopper behavior in e-tailing: An empirical analysis", Paradigm, vol. 13, no. 1, pp.73-83. 2009
} 
Ако веб страната е пребавна, тешко се навигира или не е доволно безбедна, ќе има негативен ефект врз желбата на потрошувачот да проба да купи или да купи производи од вебсајтот. Според Broekhuizen и Huizingh искуството на потрошувачите со онлајн купување, или вештините на потрошувачите - кои се однесуваат на знаењето кое потрошувачите го имаат за производот, или за начинот на онлајн плаќањ исто така влијаат врз однесувањето при онлајн купување.

Според Laudon и Traver (2009) однесувањето „Clickstream“ (течение на кликови) е уште еден аспект кој станува се побитен во онлајн светот. „Clickstream“ го означува однесувањето на потрошувачите при барање на информации онлајн, преку разгледување на повеќе веб-страници на повеќе сајтови во исто време, потоа концентрирање на повеќе страници на еден сајт, па на една страна на еден сајт и конечно на донесување на одлука за купување. Сите овие фактори доведуваат до специфични ставови и однесувања на купувачите за онлајн купувањето и чувство дека тие можат да ја контролираат нивната средина за купување во онлајн светот.

\section{1 Влијанија врз донесување на одлука за купување онлајн}

\subsection{1 Мотивации за онлајн купување}

Има многу причини зошто луѓето купуваат онлајн, како што се достапност на производите онлајн во било кое време; брза и едноставна споредба на цени и карактеристики на производите на различни онлајн продавачи во исто време; наоѓање на најдобрата понуда, не само локално, туку и на глобалниот пазар; можност за бесплатна испорака; избегнување на притисокот од лична интеракција со продавачите; избегнување на редовите и гужвите во продавница, застој во сообраќај по пат и слично. Според $\mathrm{Ch}$. Katawetawaraks и Ch.L.Wang ${ }^{5}$ овие фактори можат да бидат сумирани во четири категории - удобност, информации, достапни производи и услуги и ефикасност на трошоци и време.

\subsubsection{1 Удобност}

Емпириските истражувања покажуваат дека удобноста и практичноста на интернетот е еден од факторите кои влијаат врз желбата на потрошувачите да купуваат онлајн (Wang et al., 2005) ${ }^{10}$. Онлајн купувањето е достапно за купувачите деноноќно, во споредба со

\footnotetext{
${ }^{10}$ Wang, C.L., Ye, L.R., Zhang, Y. and Nguyen, D.D. "Subscription to fee-based online services: What makes consumer pay for online content?” Journal of Electronic Commerce Research, vol.
} 
традиционалните продавници, бидејќи е отворено 24 часа на ден, 7 дена во неделата (Hofacker, 2001; Wang et al., 2005). Според The Tech Faq (2008) истражувањата покажуваат дека 58 проценти од купувачите избираат да купуваат онлајн бидејќи можат да купуваат покасно, кога традиционалните продавници се затворени, а 61 процент од испитаниците избрале да купуваат онлајн, бидејќ сакаат да избегнат гужва и редици, особено за време на празниците. Потрошувачите не бараат само производи туку и онлајн услуги. Некои компании нудат онлајн услуги на располагање на клиентите 24 часа на ден. Затоа, дури и после работното време, клиентите можат да поставуваат прашања, да добиваат неопходна поддршка или помош, што е удобно за потрошувачите (Хермес, 2000).

Некои потрошувачи користат онлајн канали само за да избегнат интеракција лице во лице со продавачот, бидејќи се чуствуваат дека се под притисок или непријатно кога имаат контакт со продавачите, па не сакаат да бидат изманипулирани или насочувани (Goldsmith и Flynn, 2005) $)^{11}$; Ова е особено точно за оние клиенти кои можеби имале негативно искуство со продавач, или едноставно сакаат да бидат слободни и сами да одлучуваат без присуство на продавачи.

\subsubsection{2 Информации}

Интернетот го олеснува пристапот до информации (Wang et al., 2005). Бидејќи клиентите ретко имаат можност да ги допрат и почувствуваат производите и услугите на интернет пред да донесат одлука за купување, онлајн продавачите вообичаено обезбедуваат повеќе информации за производот што корисниците можат да ги користат при купувањето (Lim и Dubinsky, 2004) $)^{12}$. Клиентите ги користат информациите што ги задоволуваат нивните потреби за информации (Keency's, 1999). Освен што добиваат информации од вебстраната, потрошувачите исто така имаат бенефит од коментарите и рецензиите на производите од страна на другите корисници. Тие можат да ги прочитаат рецензиите и коментарите пред да донесат одлука.

\subsubsection{3 Достапни производи и услуги}

Е-трговијата го направи купувањето полесно од кога било досега. Потрошувачите на интернет можат да најдат најразлични видови на производи од целиот свет, кои инаку не

6, no. 4, pp.301-311. 2005

${ }^{11}$ Goldsmith, R.E. and Flynn, L.R. "Bricks, clicks, and pix: apparel buyers' use of stores, internet, and catalogs compared", International Journal of Retail \& Distribution Management, vol. 33, no. 4, pp.271-283. 2005

${ }^{12}$ Lim, H. and Dubinsky, A.J. "Consumers' perceptions of e-shopping characteristics: An expectancy-value approach", The Journal of Services Marketing, vol. 18, no. 6, pp. 500-513. 2004. 
би им биле достапни. Повеќето компании имаат сопствени веб-страници и нудат производи или услуги преку интернет, без разлика дали веќе имаат традиционална офлајн продавница или не. Многу традиционални продавници продаваат одредени производи само на интернет за да ги намалат трошоците за малопродажба или за да им понудат на потрошувачите поголем избор на големини, бои или карактеристики на производите.

\subsubsection{4 Ефикасност на трошоци и време}

Купувачите кои купуваат онлајн често можат да го најдат истиот производ по пониска цена отколку во традиционална продавница. Исто така онлајн потрошувачите можат да ги споредат цените на истиот производ во различни продавници и да ја одберат најевтината понуда. Онлајн може да се купи од било каде и во секое време, што го олеснува животот на потрошувачите, бидејќи тие не мораат да губат време во сообраќај, да бараат паркинг место или да чекаат во редици за плаќање (Childers et al., 2001) ${ }^{13}$. Па затоа онлајн продавниците им нудат удобност на потрошувачите и можат да ги намали нивните трошоци (Prasad и Aryasri, 2009).

\subsection{2 Фактори кои ги попречуваат потрошувачите да купуваат онлајн}

Според Katawetawaraks и Wang главни причини кои ги попречуваат потрошувачите да купуваат онлајн се: необезбедено плаќање, бавна испорака, можност за испорака на непосакуван производ, спам или вирус, досадни е-меил пораки и технолошки проблеми.

Бизнисот треба да биде свесен за овие проблеми кои доведуваат до незадоволство при онлајн купувањето.

\subsubsection{1 Нематеријалноста на онлајн производите}

Некои производи имаат помала веројатност да се купат преку интернет поради нематеријалната природа на онлајн производите. На пример, помала е веројатноста клиентите да купат облека преку интернет (Goldsmith и Flynn, 2005), бидејќи немаат можност да ја пробаат или да ја испитаат (Comegys et al., 2009). Клиентите кои го гледаат производот на компјутерски екран може да добијат поинаков ефект отколку кога го гледаат во продавница (Federal Trade Commission, 2003). Збирно, клиентите не можат да ги гледаат, слушаат, чувствуваат, допираат, мирисаат или пробаат производите што ги сакаат при користење на онлајн канал. Во многу случаи, клиентите претпочитаат прво да го испитаат производот и потоа да одлучат дали сакаат да го купат или не (Junhong, 2009).

\footnotetext{
${ }^{13}$ T.L., Carr, C.L., Peck, J. and Carson, S. "Hedonic and utilitarian motivations for online retail shopping behavior,"
} Journal of Retailing, vol. 77, no. 4, pp.511-535. 2001. 
Некои луѓе сметаат дека информациите за производите кои се дадени на веб-страната не се доволни за да се донесе одлука. Онлајн купувачите ќе бидат разочарани ако информациите за производот не ги исполнуваат нивните очекувања (Лиу и Гуо, 2008).

\subsubsection{2 Социјален контакт}

Додека некои клиенти сакаат да бидат ослободени од притисокот од продавачот, во голем дел од онлајн купувањата би било тешко да се направи избор, па некои клиенти би се разочарале доколку немаат стручна помош од професионален продавач (Prasad и Aryasri, 2009). Покрај тоа, некои клиенти се високо социјално поврзани и се потпираат на мислењата на другите луѓе при донесување одлука за купување. Според Prasad и Aryasri (2009) постојат и потрошувачи кои понекогаш купуваат во традиционална продавница затоа што сакаат да ги исполнат своите забавни и социјални потреби кои се ограничени во онлајн продавниците.

\subsubsection{3 Незадоволство од онлајн шопинг}

Минатото искуство со онлајн купувањето често влијае врз одлуката за идно купување. Во онлајн шопингот, на пример, купувачите можат да добијат несакани производи, производ со низок квалитет, производ кој не одговара на она што е опишано или очекувано (Comegys et al., 2009). Производот може да биде скршен, погрешен или да не функционира. Некои онлајн продавници можеби нема да се согласат да ги вратат тие производи, иако тоа не е она што клиентот го сакал. Испораката е уште еден фактор кој влијае на одлуката за купување на интернет. Бавна или задоцнета испорака, го одбива клиентот од онлајн купување (Comegys et al., 2009).

\section{4. Потребни карактеристики на веб-сајт соодветен за онлајн купување}

По разгледувањето на главните мотивации кои ги наведуваат корисниците да купуваат онлајн, онлајн продавачите треба да разберат зошто некои потрошувачи се двоумат да купуваат преку интернет, како и да пронајдат начини да ги намалат негативните аспекти од онлајн купувањето, со цел да стекнат повеќе клиенти преку градење доверлив и безбеден веб-сајт, привлечна и корисна веб дестинација која нуди онлајн услуги и дополнителни опции. 


\section{1 Доверлив и безбеден веб-сајт}

Подготвеноста на потрошувачите да купат од одредена онлајн продавница зависи од довербата која ја имаат клиентите кон онлајн продавницата за давање на лични информации и информации за нивните платежни картички. Потрошувачите се грижат за безбедноста на трансакциите и безбедноста на податоците при купување преку интернет. Според Korgaonkar и Karson (2007) ${ }^{14}$ еден од начините да се генерира доверба кон вебстраната е добивање на уверение од организација како што е eTrust. Co тоа, веб-сајтот ќе биде посигурен и ќе ја зголеми довербата на клиентите, што ќе доведе до зголемување на продажбите.

На пример, Scribendi, услугите за уредување и лекторирање на англиски јазик, купиле SSL сертификат од VeriSign - најдоверливиот бренд на интернет - па од тогаш посетителите кои ја виделе зелената лента за адреси ја зголемиле продажбата за 27\% (Verisign, 2009). Кога компаниите го имаат овој сертификат, полето за адреса на нивната веб-страница ќе се смени во зелена боја и веб-адресата ке започне co https://, па така клиентите ќе знаат дека веб-страната е безбедна и доверлива (Verisign, 2009).

Друг начин на кој продавачот може да ја намали загриженоста на клиентите при купувањето на интернет е да продава брендирани производи на веб страната или дури да има свое сопствено бренд име како Амазон (Korgaonkar и Karson, 2007). Според Лим и Дубински нудењето и продажбата на брендирани производи може да ја подобри довербата кон веб-страницата. Името на брендот е едно од најважните работи кои влијаат врз донесување на одлуката за купување

Безбедноста онлајн е една од најбитните работи кои влијаат на успехот или неуспехот на онлајн трговците на мало (Prasad и Aryasri, 2009). Безбедноста ги загрижува клиентите и може да ги спречи да купуваат онлајн (Laudon и Traver, 2009), бидејќи се загрижени дека онлајн продавницата ќе ги измами или ќе ги злоупотреби нивните лични податоци, особено податоците за нивните платежни картичка (Comegys et al., 2009).

Неопходно е онлајн-компаниите да ги убедат клиентите дека никогаш нема да ги користат нивните информации за други цели, преку јасна политиката за приватност. Ова ќе ја намали загриженоста на потрошувачите за безбедноста на нивните податоци.

\section{2 Веб-сајт пријатен за корисниците}

При донесување на одлука од кој сајт или продавач да купат, големо влијание врз потрошувачите може да има и имиџот на веб страната. Не само што сајтовите треба да

\footnotetext{
${ }^{14}$ Korgaonkar, P.A. and Karson, E.J. “The influence of perceived product risk on consumers'

e-tailer shopping preference", Journal of Business and Psychology, vol. 22, no. 1, pp. 55-64. 2007.
} 
бидат безбедни, туку тие треба да бидат и атрактивни и корисни. Онлајн продавниците можат да ги претворат посетителите во купувачи доколку нудат различни и корисни информации за производот, добра услуга за потрошувачите и сајтови кои се лесни за пристап и користење (Laudon и Traver, 2009). Веб страните треба да имаат доволно информации, но да не бидат претрупани со информации. Поставување на неструктурирани или некорисни информации на сајтот ја намалува корисноста на сајтот и едноставноста при работата (Bigné-Alcañiz et al., 2008) ${ }^{15}$. Компаниите и трговците треба два пати да препроверат да не имаат грешки во информациите и да не ги доведат потрошувачите во заблуда. Квалитетот на информациите и визуелниот дизајн имаат значајно влијание врз одлуката за купување. (Koo et al., 2008).

Подготвеноста за купување онлајн ќе биде мала доколку на онлајн продавницата пребарувањето и споредувањето на производите не е лесно и не се ажурирани податоците за производите. Онлајн продавницата треба да ја направи својата веб-страна да биде лесна за пребарување на производи и услуги. Главно нешто кое ги привлекува потрошувачите е веб страните да бидат ажурирани, софистицирани, пријатни и лесни за употреба.

Покрај тоа, доколку онлајн продавниците сакаат да го претворат посетителот во купувач, тие треба да го подобрат својот веб-сајт, нудејќи им на клиентите удобен, логичен, интересен процес и лесен јазик, создавајќи брза веб страна со функционален дизајн (Broekhuizen и Huizingh, 2009) ${ }^{16}$. Процесот на плаќање преку интернет е друго прашање за кое треба да се води грижа, бидејќи тоа влијае на подготвеноста да се плати (Wang et al., 2005). Онлајн продавниците треба да го направат својот процес на плаќање што е можно поедноставен и посигурен. Сумирано, ако онлајн продавниците сакаат да го зголемат бројот на клиенти, тие треба да се грижат нивниот веб-сајт да биде лесен за употреба и корисен за корисниците (Bigné-Alcañiz et al., 2008).

\section{3 Онлајн услуги}

Услугата на потрошувачите е исто толку битна како и квалитетот на веб страната (Лиу и Гуо, 2008). Според Хермес (2000), 72 проценти од онлајн-потрошувачите откриле дека услугата на купувачите е главен фактор во задоволството од онлајн продажбата. Ако услугите за купувачите не се достапни, потрошувачите ќе сфатат дека компаниите се обидуваат да сокријат нешто или не планираат да ги решат нивните проблеми. Онлајн

\footnotetext{
${ }^{15}$ Bigné-Alcañiz, E., Ruiz-Mafé, C., Aldás-Manzano, J. and Sanz-Blas, S "Influence of online shopping information dependency and innovativeness on internet shopping adoption", Online Information Review, vol. 32, no. 5, pp. 648667. 2008.

${ }^{16}$ Broekhuizen, T. and Huizingh, E, "Online purchase determinants: Is their effect moderated by direct experience?" Management Research News, vol. 32, no. 5, pp. 440-457. 2009.
} 
продавниците треба да ја обезбедат додадената вредност која ја нуди услугата на клиентите (Wang et al., 2005) и да имаат канал за повратни информации од клиентите на нивната веб-страна (Ју и Ву, 2007). Треба да постои интерактивна служба за корисници на веб-страната, така што клиентите ќе можат да контактираат со продавачот било каде и во секое време (Лим и Дубински, 2004). Преземање на софтвер, пополнување на е-форма, следењето на статусот на нарачките, коментари на клиентите и повратни информации се еден од примерите што онлајн продавачите можат да ги користат како свои онлајн услуги (Лим и Дубински, 2004).

\section{4 Дополнителна опција}

Бидејќи клиентите не можат да ги допрат или пробаат производите пред да ги купат, онлајн продавницата треба да им понуди некои дополнителни опции. На пример, гаранцијата за враќањ на парите е едно од средствата за намалување на загриженоста на потрошувачите (Comegys., 2009). Продавачите треба да понудат политика за гаранција за враќање на парите, со цел да го намалат ризикот од онлајн купување. Покрај тоа, за да се избегне каснење на испораката и можноста за губење на производот, онлајн продавницата може да соработува со други компании со експертиза во логистика со цел да ги подобри своите дистрибутивни канали (Yu и $\mathrm{Wu}, 2007)$.

Нудејќи им на клиентите пофлексибилни цени и промоции или нудејќи им едношалтерски услуги за купување, се уште неколку примери кои онлајн продавниците можат да ги искористат за да го направат својот бизнис поуспешен (Yu и Wu, 2007).

Доколку одредена онлајн продавница сака да биде успешена и да генерира онлајн продажби, најпрво треба да има безбеден и доверлив сајт кој ќе ја гарантира безбедноста на внесените податоци на посетителите. Најдобро е да има уверение од светско позната организација како што е eTrust или SSL сертификат од VeriSign. Понатаму треба да има политика за приватност на сајтот, каде јасно ќе биде назначено за кои цели ќе се користат податоците на посетителите.

Со цел сајтот да биде пријатна дестинација за онлајн купување, тој мора да има атрактивен визуелен дизајн. Веб-сајтот мора да ги има сите неопходни информации за производите, кои ќе бидат презентирани на концизен начин, да има опција за пребарување, како и да има брз и едноставен процес за онлајн плаќање на производите. Сајтот треба да обезбеди дополнителни услуги на корисниците, како 24/7 интерактивна служба за контакт со корисниците, опција за коментари под секој производ - каде 
корисниците ќе го споделат своето искуство со производот, како и гаранција за враќање на парите доколку производот не изгледа како што бил прикажан или е оштетен.

При дизајнирањето на веб-сајтот за намената на мојата магистерска работа, јас ќе ги применам сите овие совети, со цел да креирам оптимален сајт за онлајн продажба, кој ќе го забрза процесот за донесување одлука за купување онлајн и би ги зголемил онлајн продажбите.

\section{5. Имплементирање на аугментираната реалност во продажбата}

Аугментираната реалност (АР) ќе има најголемо влијание врз искуството на купувачите при купувањето. Аугентираната реалност ги прикажува нормалните погледи на реалноста, кои се збогатени со дигитално генерирани информации или графики.

Аугментираната реалност има способност да ги брише границите помеѓу реалниот и виртуелниот свет, а со тоа и границите помеѓу купување преку интернет и во продавница. AР им дава на онлајн купувачите искуство како во продавница, помагајќи да се разгледуваат производите во реални средини, како и пробување на истите, што е особено важно при купување на облека и мебел. На пример, АР ќе им овозможи на потрошувачите практично да ја пробаат облеката или да го сместат мебелот во домот пред да го купат.

Ова може значително да помогне при намалување на враќњата на производите кои не се погодни за сопственото тело или на личниот простор, како што се облека и мебел. Според анкетата на Американската национална федерација за малопродажба, вратената стока ги чинела трговците во САД 284 милијарди долари во потенцијална продажба ${ }^{3}$

AР технологијата ќе им овозможи на корисниците да ги гледаат производите во реална димензија во своите домови, што ќе охрабри директно купување на производите од нивните мобилни уреди.

Аугментираната реалност ќе биде нашироко користена за подобрување на искуството во продавниците, особено за концептните и изложбените продавници кои стануваат се попопуларни особено за одредени скапи брендови.

\section{1 Потребата од технологијата на аугментирана реалност во онлајн купувањето}

Аугментираната реалност му овозможува на корисникот да го види реалниот свет, со виртуелни објекти надредени врз него или вклопени со него. Оттука, аугментираната 
реалност ја дополнува реалноста, наместо целосно да ја замени (како што е случајот со виртуелната реалност).

АР е дополнување на реалниот свет со виртуелни објекти кои се појавуваат за да коегзистираат во истите полиња или простор како во реалниот свет. ${ }^{17}$ Во опкружување, услови и поставки на АР, виртуелните производи може да бидат прикажани и трансформирани во реално време на екранот, овозможувајќи му на корисникот да има интерактивно искуство со виртуелниот производ во средина од реалниот свет. Конечно, ова нуди нов пристап за примена на АР технологијата за работа во ентериерниот дизајн, каде што корисникот може да гледа виртуелни производи и да комуницира со нив со користење на динамичен и флексибилен кориснички интерфејс.

Еден од главните недостатоци на традиционалниот систем за е-трговија е тоа што производите прикажани на веб-страните не можат да се допрат. Овој недостаток донекаде се надминува со аугментираната реалност.

AP функционира така што: камерата на смартфонот ќе го пренесе физичкото опкружување на потрошувачот на екранот и потоа оваа околина ќе се интегрира со виртуелниот објект или ЗД моделите на производите во реално време. Корисникот тогаш може да има интеракција со производите за да утврди дали се соодветни и да испроба различни бои, материјали, димензии, модели, положби, итн.

\section{2 Историјат на аугментираната реалност}

На областа на аугментираната реалност и било потребно подолго време за да се развие, генерално како резултат на комплексните технолошки спецификации кои биле неопходни за нејзина соодветна примена. Фундаменталните елементи неопходни за да се изгради АР систем (дисплеи, уреди за следење и компјутерски графички софтвер) останале исти за многу системи уште од самиот почеток на развојот на оваа технологија во 1960-тите години. ${ }^{18}$ Иако терминот аугментирана реалност бил креиран во раните 1990-ти, првите целосно функционални АР системи биле направени во доцните 1960-ти, кога Ivan Sutherland и неговите колеги (1968) изградиле механички ЗД провирен дисплеј кој се носел на глава и преку кој носителот можел да види информации генерирани од компјутер, измешани со физички предмети од реалниот свет, како знаци на лабораториски sид. Во следните неколку декади биле направени многу истражувања со цел да се овозможи компјутерите да генерираат графички информации, па растечката област на

${ }^{17}$ S. Dongre, S. Dube \& P. Patil. Home Decor Shopping Using Augmented Reality; International Journal of Computer Science, and Engineering (IJCSE); - Vol. 5, Issue 2, pp. 15-22. 2016.

${ }^{18}$ Brito, Pedro \& Stoyanova, Jasmina \& Gonçalves, Ricardo \& Coelho, António. Real-time Augmented Reality Pemo Platform for Exploring Consumer Emotional Responses with Shopping Applications. International Journal of Online Engineering (iJOE). 9. pp 41-43. 2013 
интерактивната компјутерска графика започнала да цвета. Фотореалистичните компјутерски генерирани слики станале подрачје за истражување во доцните 1970-ти години и прогресот во технологијата за тракинг ја зголемил надежта за креирање на врвна машина за симулација. Па започнала да се појавува областа на виртуелна технологија. Литературата за научна фантастика, а особено движењето cyberpunk во 1980-тите години, креирале визии на симбиоза помеѓу човекот и машините. Забавната индустрија се вклучила во трендот со филмови како Терминатор, кој презентира конкретна визија како би изгледал светот со развојот на компјутерската технологија. ${ }^{19}$ За време на 1970-тите и 1980-тите, АР била тема за истражување во многу институции, како Лабораторијата "Армстронг" на Американските Воздухопловни сили, Истражувачкиот Центар на НАСА "Ames", Технолошкиот институт во Масачусетс и Универзитетот во Северна Каролина во Чапел Хил. Како дел од проектот на Американските воздухопловни сили - Super Cockpit, Tom Furness развил дисплеј за глава со висока резолуција за воени пилоти, кој ја прекривал реалноста со аугментирана реалност и бил поддржан со ЗД звук (Furness, 1986). 20
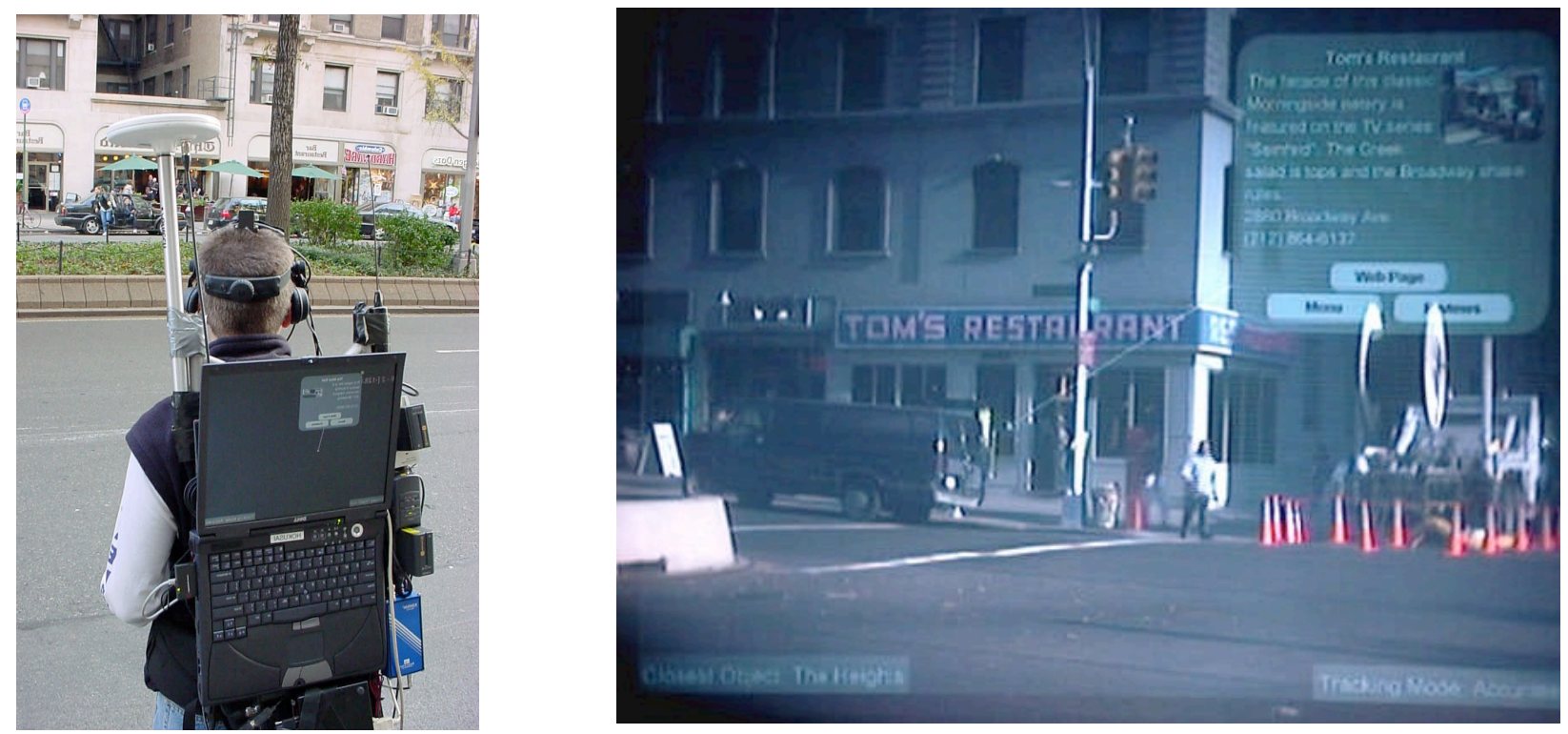

Слика 3 - Мобилен АР водич за ресторан. (а) Корисник со МАРС ранец, гледа во ресторан. (б) Анотиран поглед на ресторанот, прикажан преку екранот што се носи на главата.

Технологијата за аугментираната реалност го добила своето име дури во раните 1990-ти години, со истражувањето на Boeing корпорацијата во која идејата за прекривање на реалниот свет со компјутерска графика се нарекла аугментирана реалност. Во овој период Caudell и Mizell (1992) $)^{21}$ работеле во Boeing за поедноставување на процесот за

${ }^{19}$ Höllerer, Tobias \& K Feiner, Steven. Mobile Augmented Reality, Chapter 9. 2017

${ }^{20}$ Furness, T. The super cockpit and its human factors challenges. In Proc. Human Factors Society 30th Annual Meeting, pages 48-52, Santa Monica, CA. 1986

21 Mizell, D. Boeing's wire bundle assembly project. In Barfield, W. and Caudell, T.,editors, Fundamentals of Wearable Computers and Augumented Reality, pages 447-467. Lawrence Erlbaum Assoc, Mahwah, NJ. 2001. 
пренесување на инструкции за вмрежување на авионите на работниците, и тие први го нарекле нивното предложено решение за покривање на реалниот свет со компјутерски генериран материјал - аугментирана реалност.

Иако ова апликација била замислена земајќи ја во предвид мобилноста, вистинската мобилна аугментирана реалност останала недостапна во следните неколку години. Во раните 1990-тите години, Loomies и неговите колеги (1993) во Универзитетот на Калифорнија, Санта Барбара, развиле ГПС базиран систем за надворешно користење, кој бил навигациска помош за лицата со оштетен вид преку просторни и аудио преклопувања.

Во средината на 1990-тите години компјутерите и трекинг уредите станале доволно моќни, а во исто време доволно мали за да поддржат компјутерски генерирани графички преклопувања во динамична мобилна околина. Колумбиската „Touring Machine“ (Feiner et al., 1997) била ран прототип на надворешниот мобилен АР систем (МАРС) кој претставувал 3Д графичка тура со информации за посетителите на кампусот, дополнета со информации за зградите и артефактите кои посетителите можеле да ги посетат.

Преносните компјутери станале популарни во 1990-тите години, кога персоналните компјутери станале доволно мали за да можат да се пренесуваат или носат цело време. Првиот преносен систем бил аналоген компјутер со специјална намена за предвидување на резултатите од коцкарски настани, направен во 1961 година (Thorp, 1998)22.

Од комерцијална страна, компјутерите кои можеле да се држат во дланка го претставувале трендот кон минијатуризација. Потеклото им било од Psion I Organizer од 1984 година, а подоцна станале достапни со воведувањето на Apple Newton MessagePad во 1993 година и Palm Pilot во 1996 година. Од средината на 1990-тите години, преносните компјутери имале се поголема комерцијална поддршка. Минијатуризацијата и повтиното производство на опремата за мобилни компјутери резултирала во тоа повеќе компании да понудат комерцијални преносни компјутери (на пр. Xybernaut, Charmed Technology, ViA, Antelope Technologies).

\section{3 Компоненти на мобилни АР системи (МАРC)}

Неопходни компоненти потребни за мобилните АР системи се:

\subsection{1 Компјутерска платформа}

Компјутерска платформа која ќе генерира и менаџира виртуелен материјал кој ќе се постави како дополнителен слој врз физичката реална околина, ќе ја процесира информацијата од тракерите и ќе го контролира АР дисплејот.

${ }^{22}$ Thorp, E. O. The invention of the first wearable computer. In Proc. ISWC '98 (Second Int. Symposium on Wearable Computers), pages 4-8. 1998. 


\subsection{2 Дисплеј}

Следно што е потребно е дисплеј, кој ќе го презентира виртуелниот материјал во контекст на физичкиот свет. Во случајот на аугментирање на визуелните сетила, ова може да биде дисплеј кој ќе се носи на глава, дисплеј кој би се држел во рака или дисплеј интегриран со физичкиот свет. Другите сетила (слушање, допир или мирис) исто така потенцијално можат да се аугментираат. Просторниот звук често се користи за да пренесе локализирани информации, или да ги дополни или комплетно да ги замени визуелните елементи (Sawhney и Schmandt, 1998). ${ }^{23}$

\subsection{3 Регистрација на реалната околина}

Регистрацијата на реалната околина исто така треба да биде земена во предвид: усогласување на виртуелните елементи со физичките објекти кои ги интерпретираат. Визуелната и звучната регистрација може да се направи преку следење (tracking) на позицијата и ориентацијата на главата на корисникот и поврзувајќи ја оваа мерка со модел на околина и/или правејќи компјутерот да ја „види“ и потенцијално да ја интерпретира околината преку камера и компјутерска визија.

\subsection{4 Преносни влезни и интеракциски технологии}

Преносните влезни и интеракциски технологии овозможуваат личност во движење да работи со аугментираниот свет (на пр. да прави селекција или да пристапи и да ја визуелизира датабазата која што содржи релевантни информации) и дополнително да го аугментира светот околу себе. Исто така овозможуваат личноста да комуницира и соработува со други МАРС корисници.

\subsection{5 Безжична мрежа}

Безжичната мрежа е потребна за да се комуницира со други луѓе и компјутери додека сте во движење. Динамични и флексибилни АР системи ќе се потпираат на информации точни до секунда кои што не можат да се складираат на компјутерскиот уред пред да се стартува апликацијата.

\subsection{6 Складирање на податоците и технологија за пристап}

Ова води до следното барање за МАРС: складирање на податоците и технологија за пристап. Доколку МАРС дава податоци за моменталната околина на корисникот, тие информации мора да ги добие од некаде. Складиштата на податоци мора да достават информации кои одговараат на моменталниот контекс на корисникот. Откривањето, управувањето и пристапот до податоци и услуги претставуваат неколку истражувачки прашања кои ги испитуваат истражувачите во базата на податоци и заедниците засновани на контекст. Од кориснички аспект, најбитното прашање е како да се добие

\footnotetext{
${ }^{23}$ Sawhney, N. and Schmandt, C. Speaking and listening on the run: Design for wearable audio computing. In Proc. ISWC '98 (Second Int. Symp. On Wearable Computers), Cambridge, MA. Pages 108-115. 1998.
} 
најрелевантната информација со најмал напор и како да се минимализира претрупаноста со информации.

Според Höllerer и Feiner, не постои целокупно најдобро решение за многу од предизвикувачките проблеми во областа на АР, како што се технологиите НКЛ за следење и прикажување. Новите истражувачки резултати постојано отвораат нови можности за истражување. Девелоперот кој планира да користи АР технологија за одредена задача, мора да донесе одлуки за дизајн кои ги оптимизираат перформансите на AP за дадената апликација, врз основа на внимателна анализа на задачите. Во некои случаи, може да биде можно да се најдат специјализирани АР решенија кои ќе работат добро во ограничени области со специјална хардверска поддршка. Ако, од друга страна, анализата на задачи за AP сценариото открива дека крајниот корисник на системот треба да биде поддржан во широк спектар на локации и ситуации, кои најверојатно вклучуваат активности на отворено, тогаш се влегува во царството на вистинскиот мобилен АР.

\section{4 Типови на аугментирана реалност}

Можат да се направат неколку класификации на аугментираната реалност во зависност од различни критериуми. ${ }^{24}$ Во зависност од хардвер уредите кои корисниците ги користат, има: статични системи, просторни системи, десктоп аугментирана реалност, рачни уреди, дисплеи кои се поставуваат на глава и контактни леќи.

\subsection{1 Статични системи за аугментирана реалност}

Ова се системи кои не можат да се движат, најчесто се опремени со помоќни камери и може да овозможат точно препознавање на објектите и сцените од реалноста. Овие типови на АР системи се користат во виртуални пробај-и-купи проекти во традиционалните продавници.

\subsection{2 Просторни системи за аугментирана реалност}

Овие системи ја проектираат виртуелната содржина директно врз објектите во реалниот свет, во реални димензии и пропорции. За овие системи има зголемен интерес во автомобилската индустрија.

\subsection{3 Десктоп аугментирана реалност}

Овие АР апликации ја користат компјутерската камера за да ги препознаат објектите во реалниот свет и да додадат виртуелни објекти на нив. Виртуелните пробај-и-купи проекти во онлајн продавниците се базираат на овој тип на АР.

\footnotetext{
${ }^{24}$ G. Kiryakova, N. Angelova, L. Yordanova, The Potential of Augmented Reality to Change the Business; Trakia Journal of Sciences, Vol. 15, Suppl. 1, pp 394-401. 2017
} 


\subsection{4 Рачни уреди}

Рачните уреди се исто така познати и како мобилна аугментирана реалност, која е екстремно популарна поради фактот што мобилните уреди (како смартфони, таблети и слично) се нашироко распространети. Повеќето од мобилните АР апликации ги користат вградените ГПС трансмитери во уредот, за да ја утврдат позицијата на корисниците. Зависно од позицијата, апликација дава информации во различни форми (текст, слики, аудио и видео) кои се директно поврзани со локацијата на корисниците и интегрирани во нивната реална околина.

\subsection{5 Дисплеи кои се поставуваат на глава}

Овие уреди овозможуваат комбинација на слики од физичкиот свет и виртуелни објекти пред полето на гледање на корисникот. Во зависност од користената технологија, овие уреди може да се поделат на Оптички и Видео дисплеи кои се поставуваат на глава. Најпопуларни претставници од оваа група на хардверски уреди се паметните наочари (smart glasses). Популарни примери се Google Glass, Vuzix Smart Glasses, Sony Smart EyeGlass, CastAR.

\subsection{6 Контактни леќи}

Тие се иднината на аугментираната реалност. Контактните леќи се во процес на развој и ќе им овозможат на корисниците да имаат комбиниран поглед на реалноста со виртуелни објекти.

Во зависност од тоа како се идентификуваат објектите и сцените, аугментираната реалност се дели на: аугментирана реалност базирана на визија и аугментирана реалност базирана на локација.

\subsection{7 Аугментирана реалност базирана на визија}

Аугментираната реалност базирана на визија може да биде базирана на маркери или без маркери.

Апликациите за аугментирана реалност базирани на маркери ја користат камерата на уредот за да ги препознаат и интерпретираат маркерите (обично црно-бели QR код слики). Софтверот го анализира маркерот и создава виртуелни објекти кои се прикажани на екранот на уредот, интегрирани во препознаените објекти од реалниот свет.

Аугментирана реалност без маркери се заснова на препознавање на објекти од реалниот свет (фотографии, корици на списанија, предмети, лица, сцени итн.). Софтверот ги препознава објектите според нивните специфични карактеристики што ги разликуваат од околните објекти. Аугментираната реалност без маркери исто така може да се имплементира со користење на линк кој го отвора производот во аугментирана реалност. 


\subsection{8 Аугментирана реалност базирана на локација}

Аугментираната реалност базирана на локација е без маркери, каде апликациите ги користат ГПС можностите на уредот за да ја одредат позицијата на уредот (односно сопственикот) и да обезбедат информации поврзани со оваа локација - на пример, информации за хотели, ресторани, музеи и останати работи кои се во околината на корисникот. ${ }^{24}$

\section{5 Примена на АР}

Очекувањата за широка примена на аугментираната реалност во скоро сите сфери на животот се базира на фактот дека хардверот кој ја поддржува оваа технологија веќе е достапен. Поголем број од корисниците веќе имаат различни паметни мобилни уреди смартфони, таблети, смарт уреди за носење и слично.

Според International Data Corporation, вкупниот приход од виртуелна и аугментирана реалност се очекува да се зголеми од 5,2 милијарди долари во 2016 година на над 162 милијарди долари во 2020 година. Повеќе од половина од приходите доаѓаат од продажбата на хардвер за виртуелна и аугментирана реалност. Софтверот е помал извор на приходи, кој пораснал за повеќе од 200\% во 2016 година во споредба со претходната година.

За да се користи аугментираната реалност потребно е да се инсталира апликација за аугментирана реалност или стандарден АР пребарувач кој им овозможува на корисниците да станат дел од мешаната реалност.

Од друга страна е тенденцијата на корисниците се повеќе и повеќе да ги користат мобилните уреди не само за забава, туку и за обуки, работа и бизнис. Аугментираната реалност е технологија која е прифатена и станува дел од стратегиите на растечки број на компании кои делуваат во различни бизнис области - производство, трговија, рекламирање, туризам и други.

\subsection{1 Примена на АР во продажбата}

Е-трговија е составен дел на денешниот бизнис. Се повеќе и повеќе луѓе купуваат онлајн, што доведува до потреба за подобрување на процесите на онлајн трговијата. Имплементацијата на новите технологии може да им помогне на компаниите да ги направат клиентите позадоволни од купувањата што ги направиле.

Аугментираната реалност може да ја промени природата и суштината на трговијата традиционалната и електронската. Напорите се насочени кон искористување на 
потенцијалот на технологијата за персонализирање и подобрување на перцепциите на корисниците за време на купувањето, нивното искуство и задоволство и подобрување на интерактивноста на шопингот. Како последица на тоа, ќе се зголеми продажбата (зголемен приход за компаниите), лојалноста на корисниците, како и подготвеноста на корисниците да ги препорачаат своите искуства на пријателите и познаниците.

Во онлајн трговијата клиентите немаат можност за интеракција со производите - не можат да ги допрат и да ги пробаат, што често е пречка за правење нарачки и купување. Според Klamann и Krastev виртуелното искуство пробај-и-купи е првиот чекор кој компаниите го превземаат при користење на технологијата на аугментирана реалност за да го зголемат ангажманот на купувачите и да генерираат нарачки и купувања преку интернет ${ }^{25}$. Апликациите за аугментирана реалност овозможуваат создавање виртуелни гардероби, каде клиентите можат виртуелно да пробаат производи. Овој пристап е популарен кај компаниите кои нудат козметика, накит, часовници, очила и сл. Тие можат да ги интегрираат на нивните веб-страници за е-трговија. Можностите да понудат ново, незаборавно, персонализирано искуство за клиентите, како резултат на комбинирање на практичноста на АР технологијата со искуството на физичките продавници, привлекува повеќе посетители во онлајн продавниците. Повеќе посетители чии очекувања се задоволени, доведуваат до поголема продажба и приходи за онлајн продавниците.

Аугментираната реалност е предмет на интерес не само за претставниците на етрговијата, туку и за традиционалните трговци. Нивната цел е да бидат конкурентни со интернет продавниците во однос на единственото искуство кое го нудат. Виртуелни гардероби може да се креираат со помош на АР технологијата во физичките продавници и корисниците можат да комуницираат со дигитални содржини и да имаат нови уникатни искуства.

\subsection{2 Примена на АР во производство и одржување}

Аугментиранта реалност може да се искористи во речиси секоја фаза од процесот на дизајнирање и производство на производите - од фазата на проектирање, до фазите на производство и последователното одржување и поправка на производите.

Аугментиранта реалност им помага на инженерите и дизајнерите да дизајнираат производи во околината каде што ќе се користат. АР технологијата им овозможува да ги земат во предвид сите фактори, карактеристики или ограничувања наметнати од околината.

Аугментиранта реалност го поддржува создавањето на прецизни проекти и нивна оптимизација. Дизајнираните производи можат да бидат тестирани, анализирани,

\footnotetext{
${ }^{25}$ Klamann, K., S. Krastev. Why Augmented Reality Will Be the Next Revolution in Retail; Strategy+Business; Consumer \& Retail; Issue 87. 2017.
} 
подложени на симулации кои овозможуваат разгледување на различни фактори во нивната употреба со текот на времето.

Производите создадени во денешно време, стануваат се́ покомплексни, што го усложнува нивното производство. Апликациите за аугментирана реалност можат да обезбедат информации во различни форми, вклучувајќи и онлајн ресурси, до вработените во производните операции во вистинско време ${ }^{26}$. Дигиталната содржина додадена на реалноста, ја подобрува ефикасноста во работата и ги оптимизира производствените процеси.

Аугментираната реалност, исто така може да им помогне на работниците во службата за дијагностицирање на дефекти и активности за поправка. Механичарите можат да видат анимирани делови кои треба да се поправат или заменат, кои алатки треба да се користат и редоследот на дејствата. Тие добиваат дополнителни тродимензионални информации или аудио инструкции за секој работен чекор. Аугментираната реалност ги олеснува активностите за поправка, го скратува времето што го преземаат и го подобрува нивниот квалитет.

\subsection{3 Примена на АР во туризмот}

Туристичката индустрија има за цел да понуди и продаде искуства и незаборавни сеќавања на потрошувачите. Аугментираната реалност може да даде значителен придонес во остварувањето на овие цели преку збогатување на искуствата на туристите и обезбедување на нови услуги за посетителите.

Корисниците можат да ја "доживеат" секоја дестинација пред да ја посетат преку аугментираната реалност. Од една страна, технологијата им овозможува на корисниците да одредат која дестинација е најдобриот избор за нив. Од друга страна, технологијата може да ги подобри и збогати вкупните перцепции и искуства на туристите за време на нивните посети.

Корисниците можат да ја користат аугментираната реалност за да имаат брз и лесен пристап до информации што се од витално значење за нивното уживање и безбедност. Туристите добиваат податоци во различни форми (мислења, критики, коментари) за хотели, ресторани, музеи, знаменитости и други локации околу нив во реално време. Податоците ја збогатуваат реалноста околу посетителите и ги прави нивните искуства уште повозбудливи и незаборавни.

\footnotetext{
26 Regenbrecht, H., Baratoff, G., \& Wilke, W. Augmented reality projects in the automotive and aerospace industries, IEEE Computer Graphics and Applications, 25(6), pp. 48-56. 2005
} 
Аугментираната реалност може да се користи во музеите и галериите за да се обезбедат мултимедијални информации еквивалентни на традиционалните аудио и видео тури, но многу побогати во смисла на содржината и формата. Многу апликации за аугментирана реалност обезбедуваат информации во форма на едукативни игри, комбинирајќи учење и забава, за да го направат искуството на посетителот поинтерактивно и интересно.

Друга примена на аугментираната реалност во туризмот е можноста да се преведе од еден јазик на друг во реално време. Постојат голем број на апликации, како што ce Google Translate, кои обезбедуваат текстуален превод на етикети, менија и знаци со користење на камерата на мобилните уреди во реално време. ${ }^{24}$

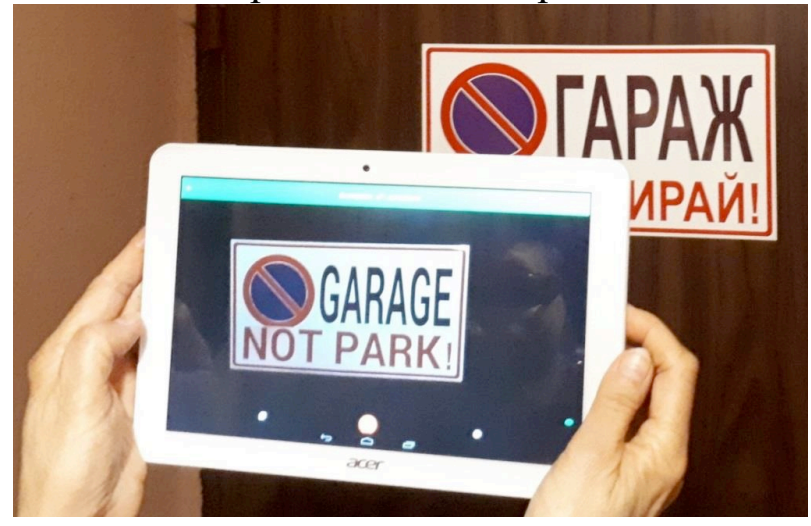

Слика 4 - Преведување на знаци co Google Translate

\subsection{4 Примена на АР во маркетинг и рекламирањето}

Аугментираната реалност придонесува за создавање интерактивни маркетиншки и рекламни кампањи кои го привлекуваат вниманието на потрошувачите и ги вклучуваат како активни учесници. Аугментираната реалност може да се смета за совршена алатка за зголемување на продажбата.

AP апликациите овозможуваат оживување на дигиталните содржини. Печатените материјали можат да се претворат во интерактивни со дополнителни 3Д објекти или да оживеат со анимации или видеа. Оваа технологија им овозможува на корисниците $360^{\circ}$ поглед на производите (тридимензионален поглед), или да ги менуваат компонентите или деталите на производите според нивните лични преференции.
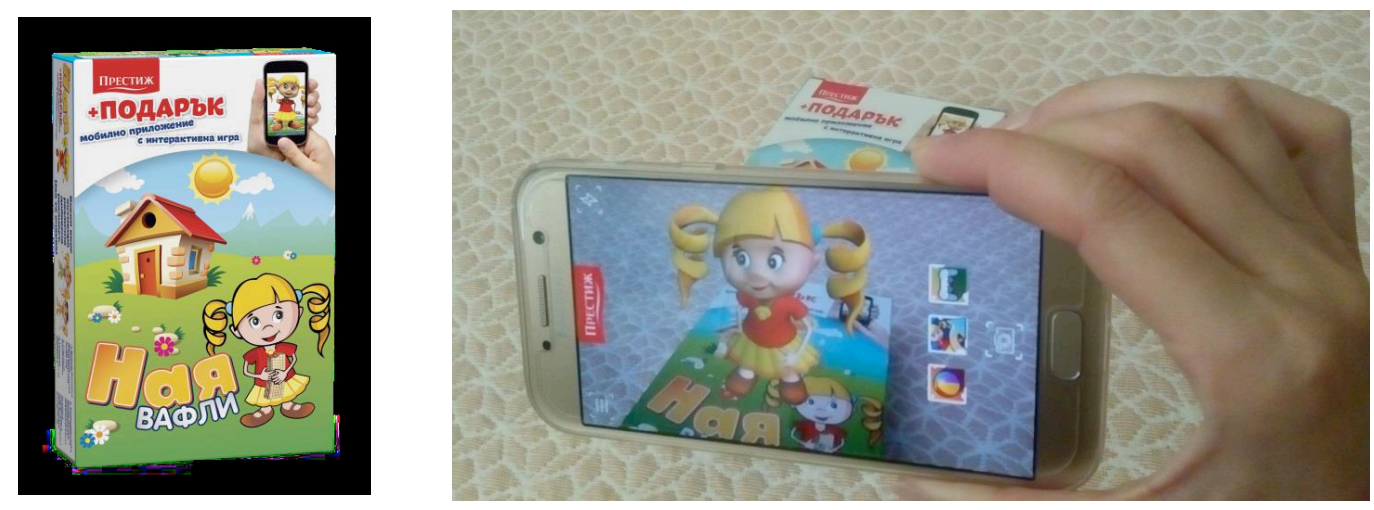

Слика 5 - Пакување на вафли Naya (компанија Prestige 96) оживува со апликацијата ScanAR. 
Аугментираната реалност овозможува поголема интерактивност во процесот на купување. Резултатот е многу повеќе забава и моќни интеракции, создавање на емоционални односи помеѓу клиентите и производите. Производот станува личен кога корисникот може да го стави во својот личен свет наместо во вештачката средина на продавниците. Персонализацијата на производите и способноста за интеракција со нив може да ги поттикне клиентите да направат вистински купувања. Од друга страна, создавањето емотивна врска помеѓу корисниците и производите ги стимулира клиентите да ги споделат своите искуства со пријателите, колегите, семејството и во социјалните медиуми. Оваа тенденција е предуслов за компаниите да изградат заедница околу нивните производи што води до висока општествена видливост и присуство на пазарот и во општеството.

Во однос на трошоците, креирањето на маркетинг или рекламна кампања со аугментирана реалност е поевтино отколку користење на традиционалните канали и медиуми, како што се телевизијата и печатените медиуми.

\section{6 Аугментираната реалност во продажбата}

Премногу долго, аугментираната реалност (АР) се сметаше за нова технологија. Сепак, покрај возбудата за Pokémon Go и Snapchat, интерактивното искуство со AP всушност може да оствари деловни цели, особено во постојано променливата индустрија на малопродажбата. ${ }^{27}$

И покрај можностите за приходи кои доагаат од онлајн продажбата, постојат и некои тешки предизвици кои компаниите мора да ги надминат за успешно да продаваат производи преку интернет.

Трговците на мало на сите пазари, воочувајќи ги можностите на е-трговијата, започнаа да ги приоретизираат своите онлајн продавници, но искуството со мобилната трговија сѐ уште се соочува со многу пречки.

"Мобилните посетители ги надминуваат десктоп посетителите и опфаќаат 61\% од вкупниот сообраќај на е-трговија. Но конверзиите се сеуште 63\% пониски на мобилни уреди, споредено со десктоп " вели студијата за мобилна трговија од 2016 година од Unbxd. Аугментираната реалност е новата иновација која ја пополнува оваа празнина, и обезбедува вистински бенефиции за трговците и купувачите. АР ќе стане алатка за

${ }^{27}$ D. Williams II. Augment, Foundations and Future of Augmented Reality and Ecommerce: How augmented reality will impact online retail, pp. 9. 2016. 
разликување помеѓу малопродажната конкуренција, обезбедувајќи вистинска вредност во областите на ангажман на потрошувачите, конверзија и намалени стапки на враќање.

AP технологијата е една од трите големи технологии кои најверојатно ќе ја променат иднината на купувањето (другите се QR кодови и мобилно плаќање). ${ }^{28}$

Аугментираната реалност е технологија која ги спојува виртуелните објекти или холограми со постоечката околина во реално време. Иако повеќето брендови ја гледаат АР како иновација за иднината, таа веќе дава резултати во онлајн продажбата, особено преку мобилен телефон. Иновациите во е-трговијата брзо напредуваат, а аугментираната реалност е во состојба да донесе физичко присуство во онлајн шопингот.

Тековните проекции покажуваат дека аугментираната реалност ќе генерира приходи од 120 милијарди долари до 2020 година (Manatt Digital Media), така што трговците на мало ја имаат секоја причина и можност да го искористат ова подобрено искуство за купувачите.

За понатамошно истражување на начините на кои аугментираната реалност ги обликува искуствата и преференците за купување на луѓето, Interactions спровеле студија со 1.062 испитаници од САД, со цел да го истражат начинот на кој купувачите ја доживуваат аугментираната реалност и како преферираат да ја користат додека купуваат. Резултатите од истражувањето покажуваат дека купувачите уживаат во користењето на аугментираната реалност и ја гледаат како забавен и нов начин за да ги истражат своите опции додека одлучуваат кој производ да го купат. Користејќи ги податоците од овој извештај, трговците на мало можат да ја искористат популарноста на аугментираната реалност на начин кој ќе ги ангажира клиентите, ќе им обезбеди уникатно и незаборавно искуство и во крајна линија ќе генерира продажби. Според оваа студија:

„71\% од купувачите почесто би купувале кај одреден трговец, доколку нуди аугментирана реалност. 40\% би платиле повеќе за одреден производ, доколку се во можност да го доживеат преку аугментирана реалност. 61\% од купувачите преферираат да купуваат во продавници кои им нудат аугментирана реалност, наспроти оние кои не им нудат “ 29

Употребата на АР-технологијата во трговијата на мало се случува на различни точки во патувањето на потрошувачите - физичко, мобилно и онлајн (Javornik, 2016; Carmigniani et al, 2011). ${ }^{30}$

\footnotetext{
${ }^{28}$ X. Zhao, C. Shi, X. You C. Zong; Analysis of Mental Workload in Online Shopping: Are Augmented and Virtual Reality Consistent; Frontiers in Psychology, pp-8. 2017.

${ }^{29}$ Retail Perceptions Report, The Impact of Augmented Reality on Retail, 2016

${ }^{30}$ Javornik, A. Augmented reality: Research agenda for studying the impact of its media

characteristics on consumer behaviour, Journal of Retailing and Consumer Services. 30:252-261. 2016.
} 
Истражувањата и апликациите на АР во трговијата на мало укажуваат на тоа дека таа се смета за олеснување на искуствениот маркетинг (Bulearca и Tamarjan, 2010) ${ }^{31}$. Раните студии на АР ги истражуваат неговите употреби во проширената трговија преку трговски агенти, за да го премости јазот помеѓу онлајн и традиционалната трговија (Brody and Gottsman, 1999). ${ }^{32}$

Истражувањата во текот на 2000-тите години за АР која се користеше во традиционалната малопродажна средина преку интерактивни екрани, кои предвидуваа дека корисниците ќе комуницираат со управлива технологија и ќе пребаруваат информации за производот, промоциите и локациите - (Sukaviriya et al, 2003)), ги истакнаа неговите функционални и хедонистички аспекти. Раните апликации на AP во трговијата на мало вклучуваат виртуелни обиди за користење на персонализирани или не-персонализирани виртуелни модели за симулирање на изгледот на комбинации на облека според формата на телото, ротирање на моделот преку предни и задни погледи кои можат да се зголемат (Lee et al, 2006). Имало спротивставени ставови за долгорочните придобивки од АР, почнувајќи од тоа дека се сметала исклучиво како промотивна алатка (Вудс, 2009) која ќе поттикне позитивни односи помеѓу потрошувачите и брендовите (Owyang, 2010) и ќе генерира задоволството кај потрошувачите со генерирање на искуствен вредносен ефект (Chou, 2009). Студијата на Bulearca и Tamarjan (2010) исто така посочила дека користењето на AP е корисно за компаниите и брендовите, со тоа што може да доведе до зголемување на лојалноста на клиентите. Преку истражување на офлајн и онлајн усвојувањето на АР добиле позитивните одговори од потрошувачите за технологијата, која им овозможила поголема интеракција со трговците, и имале преференции да купуваат од продавници кои ја нудат оваа технологија (Pantano, 2015; McCormick et al, 2014). ${ }^{31}$

Некои студии покажуваат дека влијанието на АР врз корисничкото искуство, задоволството и подобрувањето на перцепцијата на реалноста, го прави целокупното искуство забавно, пријатно и персонализирано што е релевантно за корисниците (Poushneh и Vasquez-Parraga, 2017). Ова било дополнително поддржано со наодите на Pachoulakis и Kapetanakis (2012), во кои се покажало дека аугментираната реалност (AP) која се користи за виртуелни гардероби во домовите на потрошувачите (каде корисниците преку камерата од телефонот или компјутерот можат виртуелно да пробаат како одредена гардероба им стои), придонесува кон забавниот фактор на купувањето (Pachoulakis и Kapetanakis, 2012) ${ }^{33}$. Според Craig (2013) и Javornik (2016) последователно се случил

\footnotetext{
${ }^{31}$ Bonetti F., Warnaby G., Quinn L. Augmented Reality and Virtual Reality in Physical and Online Retailing: A Review, Synthesis and Research Agenda. In: Jung T., tom Dieck M. (eds) Augmented Reality and Virtual Reality. Progress in IS. Springer, Cham, pp 119-132. 2017.

${ }^{32}$ Brody, A. B. \& Gottsman, E J. Pocket BargainFinder: a handheld device for augmented commerce, International Symposium on Handheld and Ubiquitous Computing. Springer Berlin Heidelberg. 1999.

${ }^{33}$ Pachoulakis, I. \& Kapetanakis, K. Augmented reality platforms for virtual fitting rooms, The International Journal of Multimedia \& Its Applications, 4.4:35. 2012.
} 
вртоглав пораст на мобилната аугментирана реалност, која ги искористила предностите од нашироко распространетата мобилна технологија, како смартфони и таблети. Па се појавија апликации кои ги комбинираат интеракциите водени од страна на корисниците, персонализацијата, прилагодувањето и аугментираната реалност (Magrath и McCormick, 2013), како апликацијата на IKEA која може да ја измери ширината и висината на реалната соба во домовите на потрошувачите преку објективот на камерата и да испорача многу точен примерок на мебел во релација со остатокот од околината која го опкружува (Tăbușcă, 2014, p.5). Студиите за мобилни апликации за шопинг со АР покажуваат дека ова ќе стане нашироко прифатена технологија, како резултат на високото задоволство на потрошувачите поврзано со експерименталните бенефити, заедно со предностите за трговците (Dacko, 2016) $)^{34}$.

Големите АР огледала во продавниците исто така претставуваат форма на примена на аугментираната реалност (Craig, 2013). На пример ModiFace - компанија за виртуелна технологија од САД, креирала огледало со аугментирана реалност кое ги покажува ефектите од шминка, производи за грижа на кожа и за обелување на заби, со цел да им понуди на корисниците пореално искуство пред купување на производите (Podeszwa и Baron, 2016). Слично, Rebecca Minkoff - ланец за облека, имаат имплементирано АР огледала кои прикажуваат како одредена облека ќе стои на телото на потрошувачите, само со поставување на таа облека пред нивното тело (McCormick et al, 2014).

Во следните 10 години малопродажбата ќе се смени повеќе отколку кога било кога досега во историјата на малопродажбата. Продавниците ќе станат како веб-сајтови, а вебсајтовите ќе станат како продавници. Неколку брзорастечки технологии ќе играат главна улога во оформување на начинот на кој луѓето го доживуваат шопингот. Аугментираната реалност е само една од овие технологии која ќе има централно место. Моќната комбинација на аугментираната реалност, виртуелната реалност и вештачката интелегенција ќе ја доближат иднината до нас.

\subsection{1 Примена на аугментираната реалност во традиционалната продажба}

\subsubsection{1 Паметни огледала}

Паметните огледала исто така се викаат и паметни дисплеи или дигитални огледала. Тие користат вештачка интелегенција, аугментирана реалност и технологија за препознавање на движењата. Преку комбинација на овие технологии, паметните огледала можат да прикажат облека на одразот на потрошувачите, со што гардеробите ќе станат минато.

\footnotetext{
${ }^{34}$ Dacko, S. G. Enabling smart retail settings via mobile augmented reality shopping apps, Technological Forecasting and Social Change. 2016.
} 
Огледалата стануваат виртуелни гардероби кои овозможуваат да се проба различна облека за само неколку секунди. Можат да се пробаат голем број различни комбинации на облека, без пресоблекување, во само многу мал дел од времето кое би им било потребно на потрошувачите физички да ја пробаат облеката. Овие огледала дури овозможуваат и да се сподели слика со пријателите на социјалните медиуми или облеката да се зачува за купување во иднина.

\section{Првото Дигитално Мемори огледало на Neiman Marcus First произведено од МеmоМі}

Neiman Marcus поставиле 58 MemoMi Labs дигитални огледала во 37 продавници во 2017 година. MemoMi гардеробата е комбинација од големо огледало со 70 инчен LCD екран, компјутер и HD камера која снима 8 секундни видеа. Некои од придобивките на дигиталното огледало се тоа што клиентот може да проба одредена гардероба, да сними 8 секундно видео од тоа како изгледа на него од сите агли и на лице место да види како друга боја од истата гардероба би му стоела. На крај пред да се одлучи може да разгледа како сите варијанти од облеката му стоеле и да се одлучи што да купи.

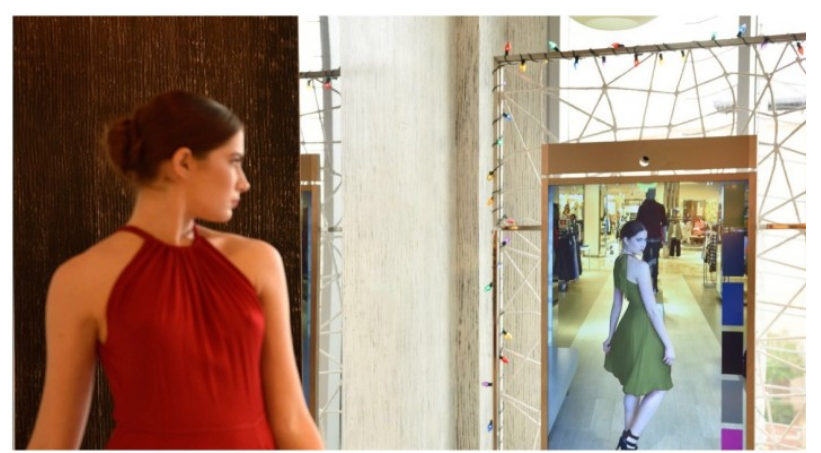

Слика 6 - MemoМi виртуелна гардероба

Некои од предизвиците од имплементирањето на технологијата за аугментирана реалност во малопродажбата е ризикот од инвестирање во овие нови форми на технологија без знаење на точно очекуваниот профит кој би се добил од нив. Кога ќе се имплементира новата АР технологија, трговците треба да ја промовираат за потенцијалните купувачи да бидат свесни за истата, како и да ги направат достапни сите потребни релевантни информации за истата. Низок степен на технолошка експертиза и посветеност на вработените, исто така е предизвик за малопродажбата, особено кога е неопходен тренинг на вработените за соодветно да ја промовираат АР технологијата на потенцијалните купувачи. Исто така цената на оваа технологија е една од пречките за нејзина имплементација, бидејќи сеуште е многу скапа за примена во традиционалните продавници и во моментов е застапена пред се во луксузните ланци за малопродажба.

Некои од предностите на примената на аугментираната реалност се подобрување на купувачкото искуство, заштедување на време на потрошувачите и креирање на нови 
маркетинг искуства. Раните прифаќачи на оваа технологија ќе ја имаат предноста од тоа да бидат перцепирани од потрошувачите и конкуренцијата како многу иновативни компании и лидери на пазарот во користење на технологија (Тео и Pian, 2003; Pantano, 2014). ${ }^{35}$

Синергијата помеѓу малопродажната индустрија и оваа иновативна технологија не е толку футуристичка како што се мисли. Потребите на потрошувачите и одредени слаби точки во продажбата веќе се потпомагаат со аугментираната реалност.Придобивките од онлајн купувањето се зголемуваат. Онлајн купувачот има пристап до голем број луксузни работи, како коментари за производи, услуги за плаќање и конфигурации на производи. Сега, кога искуството на дигиталниот медиум и искуството во продавницата мораат да работат заедно за да создадат кохезивно искуство, технологијата на аугментирана реалност им овозможува на трговците на мало да понудат поинтензивно, интерактивно патување за купувачите што ќе го смени начинот на кој купуваме засекогаш.

Денес, многу трговци ја користат аугментираната реалноста за да го донесат дигиталното искуство на физичките производи во продавниците, како и да стимулираат онлајн интеракција која ќе донесе продажба и задоволството на клиентите.Error! Bookmark not d efined.

\subsubsection{2 Лего}

Лего е една од првите компании која имплементираше аугментирана реалност во малопродажните ланци. Имплементацијата била направена преку поставување на АР киоск во кој купувачите ќе можат да ги приближат кутиите со спакуваниот, несклопен производ, прилагоден за скен од АР киоскот. Киоскот ја скенира кутијата со производот и во 3Д им прикажува како ќе изгледа финалниот производ - склопената играчка. Ова им помага на потрошувачите да одлучат кој производ да го купат, а во исто време го прави купувањето возбудливо и забавно.

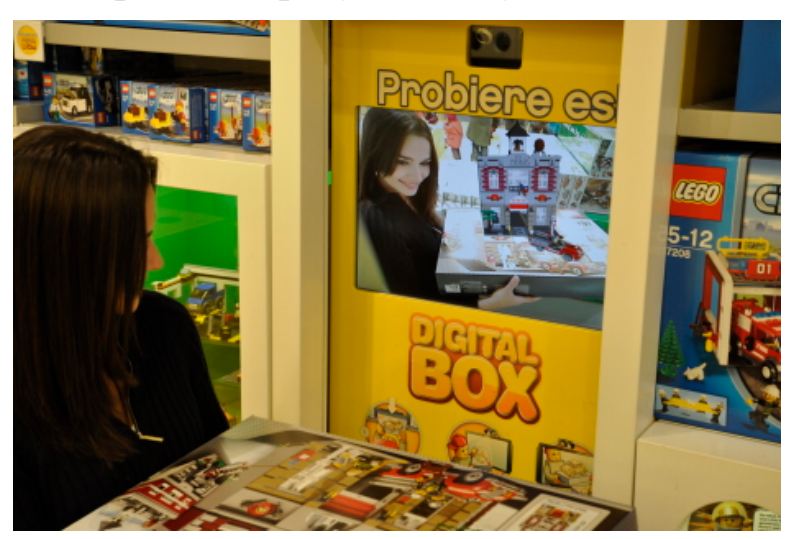

Слика 7 - пример на Лего АР киоск

35 Teo, T. S. H. \& Pian, Y. A contingency perspective on Internet adoption and competitive advantage, European Journal of Information Systems, 12(2):pp. 78-92. 2003. 


\subsection{2 Примена на аугментираната реалност во онлајн продажбата}

\subsubsection{1 Конверс}

Конверс ја креираше „The Sampler“ апликацијата за аугментирана реалност со која потрошувачите можат виртуелно да ги пробаат патиките пред да ги купат. Оваа мобилна апликација им овозможува за време на разгледување на дигиталниот каталог со производи на Конверс, да го селектираат оној производ кој ќе им се допадне, да ја насочат камерата на мобилниот кон нивното стопало и со помош на аугментирана реалност да видат како патиките би изгледале на нивната нога. На овој начин многу лесно можат да се пробаат различни модели на производи и онлајн да одлучат кој производ да го купат, без физички да ги пробаат во продавница. Оваа апликација овозможува да се сподели сликата од АР со пријателите на социјалните медиуми, доколку сакаат да добијат мислење кој производ да го одберат, како и директно да го купат производот од апликацијата преку копчето Купи.
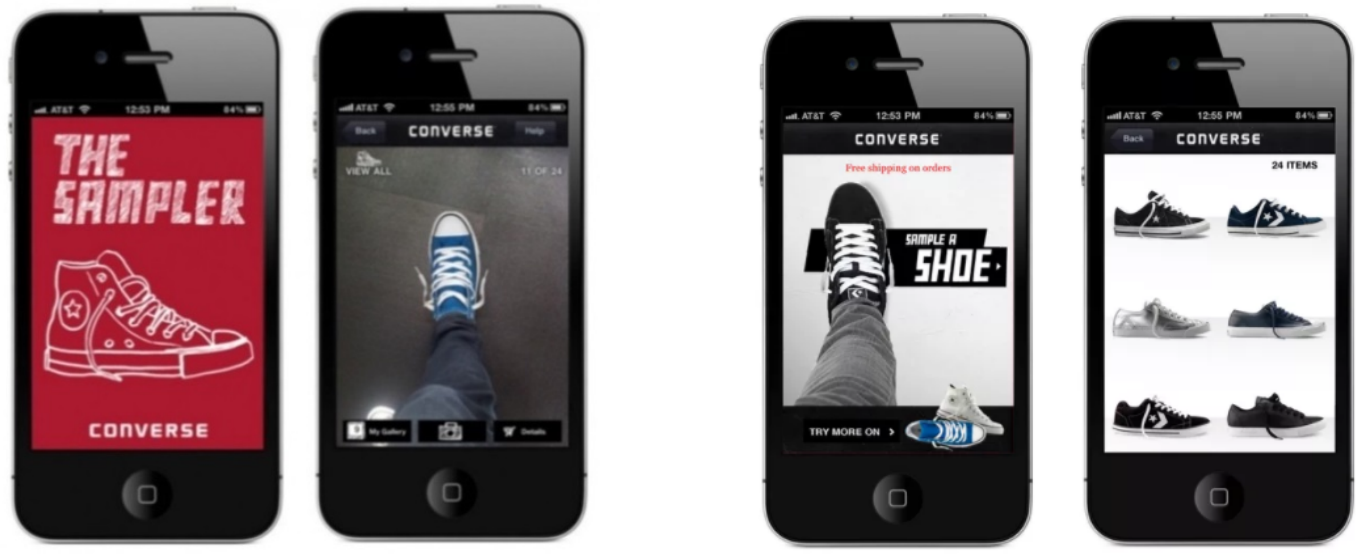

Слика 8 - The Sampler - AP апликацијата на Converse

\subsubsection{2 Икеа}

Поради постојаниот проблем со вратени производи, кои кај Икеа изнесувале дури 14\%, Икеа одлучила да имплементира аугментирана реалност за да го намали процентот на вратени производи. Аугментираната реалност ја имплементирала преку својот печатен каталог, како и преку Ikea Place мобилната апликација.

\subsubsection{IKEA Catalog App}

Првата имплементација - преку печатен каталог, користела маркери и функционирала на тој начин што потенцијалните клиенти ќе го постават каталогот на она место во домот каде што би сакале да го постават производот, па преку бесплатната мобилна апликација 2014 IKEA Catalog Apр и камерата на мобилниот телефон го гледаат 3Д производот во АР, во реална големина, на одбраното место во домот. 


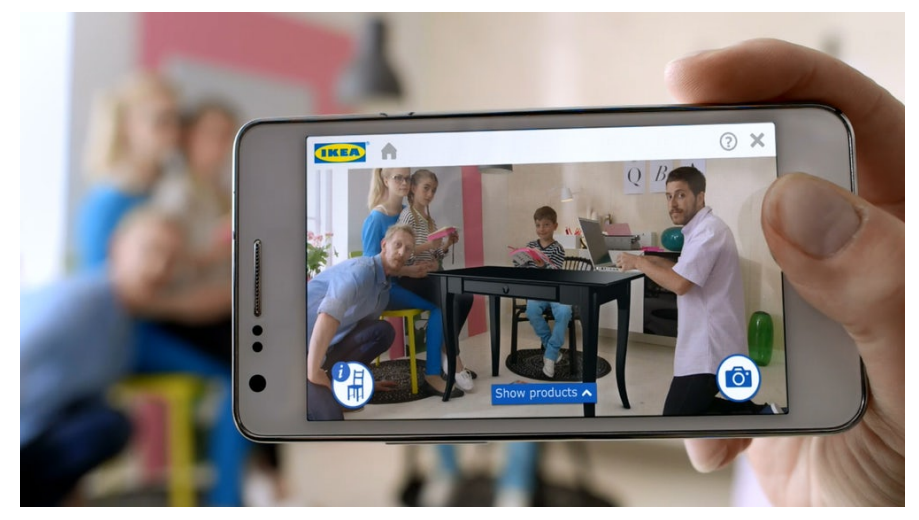

Слика 9 - Имплементација на АР преку печатениот каталог на Икеа

\section{Ikea place}

Втората имплементација на АР во Икеа е преку мобилната апликација Ikea Place, која e подобрена верзија на претходната апликација пореално ги прикажува производите во просторот, па не се случува некои производи да лебдат во воздухот и не користи печатени тракери. Оваа апликација го скенира просторот преку сензорите во камерата и побрзо ги прикажува 3Д моделите во просторот.

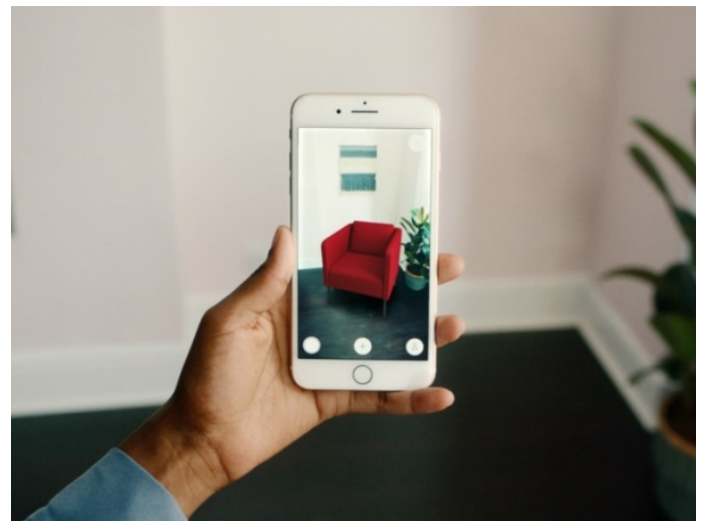

Слика 10 - Имплементација на AP преку Ikea Place апликацијата на Икеа

\section{7 Прифаќањето на АР технологијата од потрошувачите}

Според Huang и Liao $(2015)^{31}$ потрошувачите реагираат позитивно на забавната и експериментална вредност на технологијата на аугментирана реалност, нејзината интерактивност и влијание врз забрзување на процесот за донесување на одлука за купување, вкулучувајќи ги нејзините две улоги - функционална и хедонистичка.

Всушност нивото на когнитивна иновативност на потрошувачите игра битна улога во влијанието врз прифаќање и користење на технологијата на аугментирана реалност. Потрошувачите со висока когнитивна иновативност повеќе се заинтересирани за корисноста, естетиката и одлична услуга која ја нуди АР. Позитивни реакции се јавуваат од користењето на АР од онлајн купувачите. АР помага да се намали перципираниот 
когнитивен ризик кој се јавува од несигурноста при онлајн купувањето кога производите и нивните комбинации не се гледаат физички. Исто така виртуелната интеракција пред онлајн купувањето дава информации за производот што многу добро ги прикажуваат информациите кои би се добиле со директно гледање на производот во физичка продавница, со што се стимулира ментална слика (Poncin и Mimoun, 2014).

Потрошувачите очекуваат да имаат интеракција со AP апликациите кои имаат висок квалитет на аугментација (реалистичен приказ), покачено ниво на информативност, интерактивност и клучно корисни услуги (функции за пребарување, нарација, брз одговор и потреба за допир). Додека некои АР апликации нудат забава, задоволство и социјални функции што ги забавуваат и поврзуваат корисниците, многу апликации не успеваат да овозможат високо ниво на интерактивност и информативност. Ова може лесно да ги фрустрира потрошувачите и да креира незадоволство. ${ }^{36}$

Ова има битни импликации врз компаниите кои дизајнираат AP апликации. Аугментираната реалност треба да биде развиена на начин на кој таа ќе биде практичен, корисен и пријатен медиум кој ефективно ќе ги подобрува можностите на потрошувачите да извршуваат работи, како и нивната свесност за реалноста. Иако некој АР апликации се дизајнирани да ги забавуваат потрошувачите, очекувањата на корисниците ги надминуваат бенефитите од забавата. Тие очекуваат АР апликациите да понудат богат квалитет на аугментација и високи нивоа на информативност и интерактивност, па доколку дизајнерите сакаат да ги задоволат корисниците, мораат да ги имплементираат овие квалитети. Според Poushneh и Vasquez-Parraga, дизајнерите треба да се фокусираат на дизајнирање апликации кои се високо интерактивни и информативни, како дополнување на тоа што се забавни и задоволителни.

Некои АР апликации и веб страни достапни во моментов не ги задоволуваат очекувањата на потрошувачите во однос на овие квалитети. На пример Make-Up Genius e AP апликација која додава виртуелна шминка на лицето на корисниците. Иако оваа апликација нуди супериорен квалитет на аугментација, не им овозможува на корисниците да ја модифицираат или да имаат интеракција со нивната аугментирана слика, ниту пак е доволно интерактивна за да им овозможи на корисниците да зумираат или одзумираат.

Девелоперите треба да обрнат внимание и на квалитетот на аугментација, преку земање во предвид на големината и димензиите. На пример, Cimagine e AP апликација која им овозможува на корисниците да видат како виртуелен мебел би изгледал во нивниот дом. Сепак апликацијата не ги зема во предвид големината и димензиите на просторот кои му се потребни на мебелот, со ова ускратувајќи им ја можноста на корисниците виртуелно да видат колку добро мебелот ќе се вклопи на местото кое што го одбрале за него.

\footnotetext{
36 A. Poushneh, A.Z. Vasquez-Parraga. Customer Dissatisfaction and Satisfaction with Augmented reality in Shopping and Entertainment, vol.30, pp-97-119. 2017.
} 
Интерактивната аугментирана реалност со висок квалитет на аугментираност мора реалистично да ги прикаже виртуелните објекти во реалниот свет. Практичната и интерактивна AP се потпира на високо интерактивни можности кои им овозможуваат на корисниците да се чуствуваат дека имаат контрола во интеракцијата со виртуелните објекти.

Апликациите за аугментирана реалност ја дополнуваат реалноста преку мапирање на виртуелни информации во искуството на реалниот свет. Ова е битно за потрошувачите кога купуваат облека, наочари и мебел, па мора да се сфати сериозно. Недостатокот на мапирање или неговото лошо користење може да води кон незадоволство кај потрошувачите. Бидејќи прикажувањето на виртуелна содржина врз реалниот свет може да биде комплицирано, важно е девелоперите да ги земат во предвид соодветните атрибути со цел да ја направат АР задоволителна за корисниците и да биде ефикасна алатка за продажба. Добро дизајнирана аугментирана реалност треба да биде во можност да генерира богат квалитет на аугментација со висок степен на информираност и интерактивност, плус функционалности кои им овозможуваат на корисниците да имаат персонализирани и реалистични искуства. ${ }^{36}$

\section{8 Анализа на потребните модули на АР систем во онлајн продажбата}

Dongre, Dube и Patil во „Купување на домашен декор со помош на аугментирана реалност“ даваат неколку примери на чекорите во моделите на аугментирана реалност. Најчестите модели на решение за е-трговија со имплементирана аугментирана реалност вклучуваат:

Логин: Модулот за најавување кој му овозможува на секој корисник да влезе во системот. Клиентот мора да го внесе неговото корисничко име и лозинка за да се најави.

Регистрација: Овој модул е за корисници кои немаат свој профил. Тука корисникот може да создаде свој профил за најава. Создавањето на профилот се врши со пополнување на формуларот за регистрација со кориснички детали како што се името, телефон, е-пошта итн. 


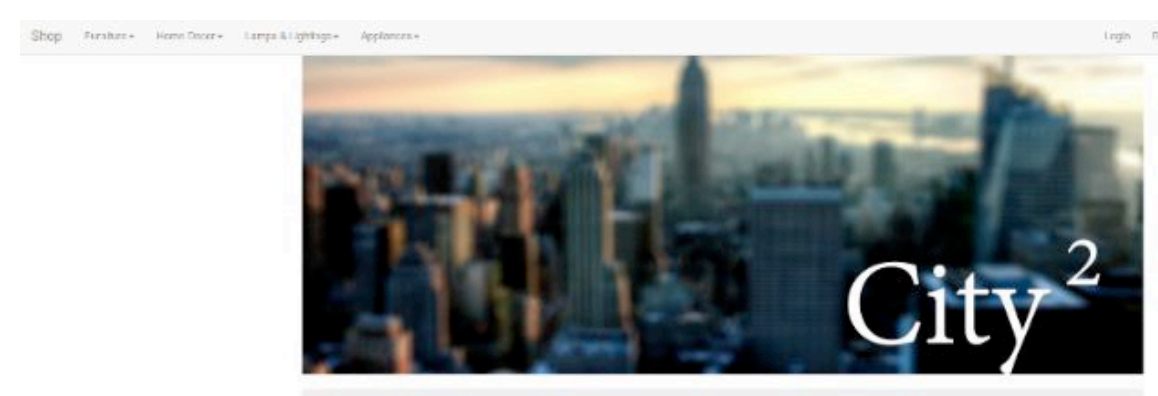

\section{Welcome User!}

we do not share any type of user celsis with any third party. Sit Back, Relax and Enjoy our services.

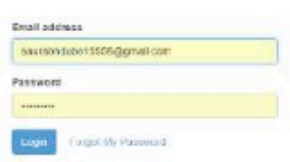

Слика 11 - приказ на страната за логирање

Производ: Овој модул според Dongre, Dube и Patil има информации во врска со производите, како што се името на производот, моделот, бојата, информации за цената, карактеристики итн. Само регистрираните корисници можат да го купат производот.
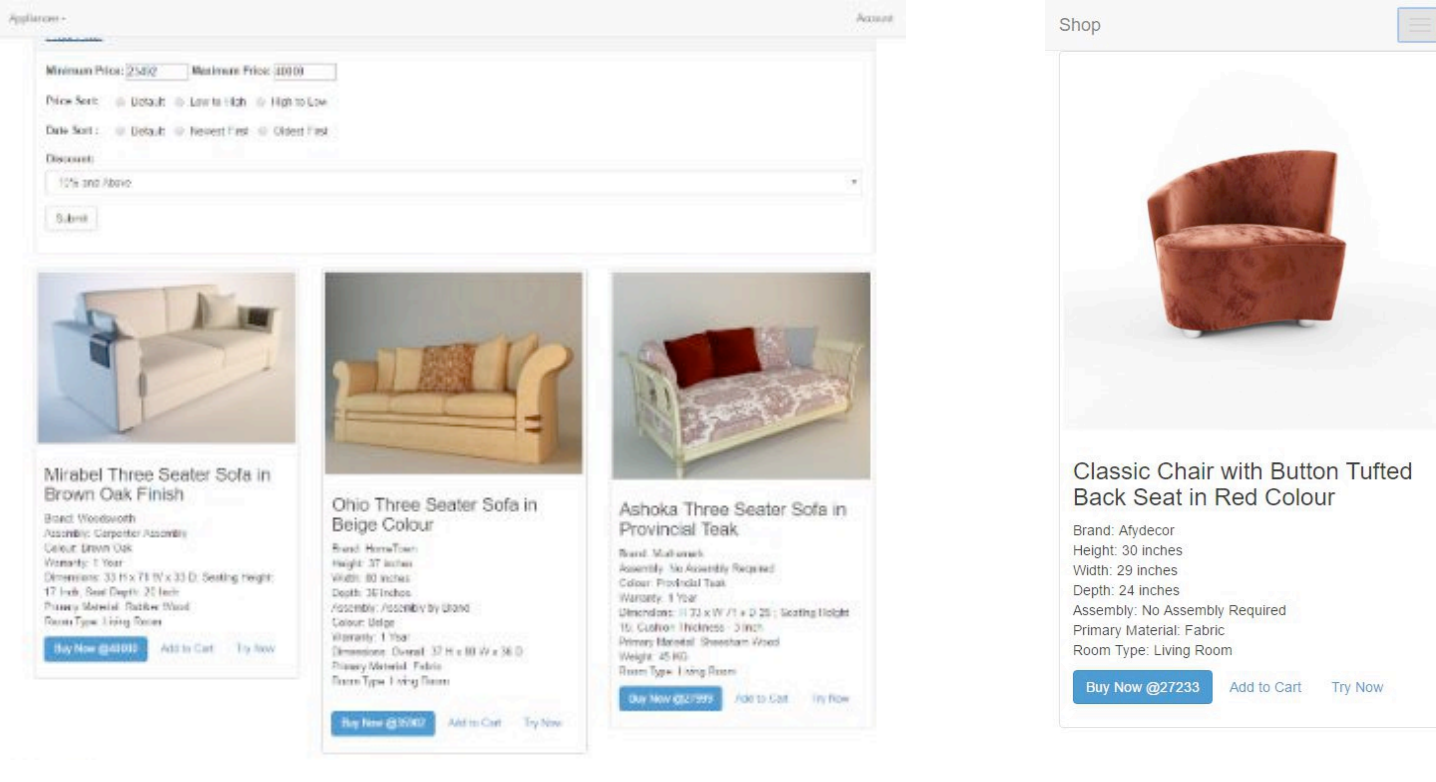

Слика 12 - приказ на производите за продажба

Слика 13 - мобилен приказ на производите за продажба

Филтер: Овој модул му помага на клиентот да го олесни пребарувањето врз основа на неговиот буџет или опции на производот. Филтерот може да се примени на различни категории како име на модел, број на модел, боја, цена итн. 
Аугметирана реалност: Овој модул ги прикажува објектите во вистинска големина преку проекција на визуелна реплика преку камерата на паметниот телефон. Може да се репозиционираат предметите во било кој агол во сопствениот простор. Со цел да се користи оваа функција, корисникот мора да симне бесплатна андроид апликација достапна на сајтот и исто така да го превземе и испечати обезбедениот маркер, кој ќе го користи за да го скенира со камерата и да го види саканиот модел.

Кошничка: Корисникот може да ги избере било кои производи и да ги додаде во кошничката. Производите од кошничката може и да се отстранат, доколку не сака да ги купи.

Плаќање: Овој модул ги опфаќа плаќањата извршени од страна на клиентот. Информациите за плаќње може да вклучуваат информации како одбран производ, количина, начин на плаќање итн.

Залиха: Овде се наоѓаат деталите за производите достапни за продажба.
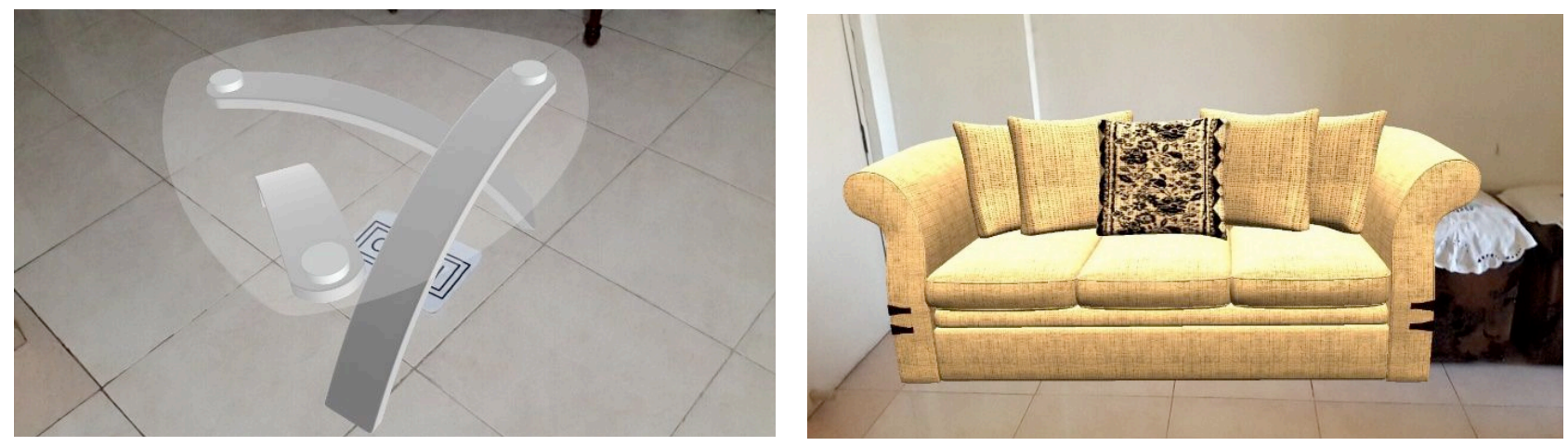

Слика 14 - пример на производи прикажани со аугментирана реалност

\subsection{1 Предности во однос на традиционалниот систем}

Според S. Dongre, S. Dube и P.Patil овој модел во однос на традиционалниот модел на купување ги има следните предности:

- Овозможува клиентите да "пробаат" пред да купат со преглед на ЗД производ

- Задоволство на клиентите

- Комбинирање на искуството од купување во традиционална продавница со етрговија

- Ја зголемува стапката на онлајн конверзии (купувања) и го намалува бројот на вратени производи, што доведува до подобрување на профитабилноста на компанијата.

- Го подобрува имиџот и препознавањето на брендот од страна на клиентите. 
Маркетингот со аугментираната реалност во малопродажбата е сеуште нов, иако може да се види значителен пораст на успешни кампањи во текот на изминатите години. Малопродажбата е многу фасцинантно поле за истражување на аугментираната реалност, бидејќ резултатите може да се видат во реално време и да се измерат, веднаш да се добијат повратни информации од корисниците и да се рашират вирално поради неговата новина. Во блиска иднина се очекуваат голем број импресивни кампањи со аугментирана реалност во малопродажбата.

При изработката на веб-сајтот за намените на оваа магистерска работа, ќ имплементирам приказ на производите во аугментираната реалност, како дополнителна опција која ќе даде додадена вредност за корисниците и значително ќе влијае врз намалување на ризиците од онлајн купување и зголемување на онлајн продажбите.

Моделот кој ќе го користам при АР имплементацијата ќе биде сличен на моделот од Dongre, Dube и Patil наведен погоре, со тоа што ќе биде малку изменет.

Според најновите истражувања, препорачливо е да се понуди опцијата за аугментирана реалност и онлајн купување без претходна регистрација и логирање на корисниците, затоа што давањето на дополнителни лични податоци онлајн ја зголемува несигурноста кај потенцијалните клиенти и ја намалува веројатноста за онлајн купување. Затоа во АР моделот кој јас ќе го предложам, нема да има потреба корисниците да се регистрираат и логираат на вебсајтот, за да ги разгледааат производите, да ги видат во аугментирана реалност и да ги купат.

На сајтот кој ќе го изработам, ќе се прикажуваат само производите кои се на залиха, па затоа нема потреба од модулот „Залиха““.

Во моделот кој ќе го изработам, исто така ќе вклучам филтри кои ќе го олеснуваат пребарувањето на производите. Опцијата „Кошничка“ и „Онлајн плаќање“ исто така ќе бидат достапни.

Како и во моделот на Dongre, Dube и Patil, и на сајтот кој ќе го изработам корисниците ќе треба да симнат бесплатна мобилна апликација, со цел да ги видат производите во аугментирана реалност. За разлика од нив, овде нема да има потреба од АР маркери кои би се печателе. Јас ќе користам АР технологија без маркери, каде корисниците ќе можат да го видат производот во аугментирана реалност преку кликнување на копче „Види го во аугментирана реалност“. Доколку корисникот го кликне копчето од смартфон, веднаш ќе биде пренасочен кон мобилната АР апликацијата која ќе му го прикаже производот во аугментирана реалност, во реални димензии во неговата околина. Доколку копчето го кликне од компјутер, ќе му се појави QR код, кој ќе треба да го скенира од мобилната AP апликација за приказ на производот во аугментирана реалност. 
Во АР апликацијата корисникот ке може на многу едноставен и брз начин да го намести производот во саканата позиција и агол, без никакви маркери, со едноставно поместување на производот со прстот на екранот на смартфонот, кон саканата позиција и агол во неговиот дом.

\section{6. Софтверски решенија за примена на аугментираната реалност во малопродажбата}

За жал сеуште нема голем број на апликации за аугментирана реалност кои се достапни за широка примена во малопродажбата. Поголемиот дел од АР апликациите кои се користат во малопродажбата се специјално изработени за таа намена, додека поголем дел од останатите АР апликации сеуште се пред се сконцентрирани на АР имплементација во игри.

Една апликација која посебно се издвојува од останатите со широк спректар на АР опции, применливи во малопродажбата e Augment.

Augment апликацијата овозможува да се визуелизира скоро секој 3Д модел во аугментирана реалност. Ова е најдобро рангираната апликација за аугментирана реалност за iPhone и Android, со повеќе од 2,5 милиони превземања / инсталации во светот.

Оваа апликација е специјално дизајнирана за да ги зголеми продажбите, да ги оживее принт креативите и визуелно да се видат производите во реалната околина на корисниците.

Откако корисниците ќе се логираат на бесплатниот Augment Manager account, апликацијата им овозможува да прикачат свои 3Д модели и тракери од апликации како Maya, 3ds Max, Cinema 4D, Sketchup и слично и да ги прикажат 3Д моделите во виртуелната околина, користејќ ја камерата на смартфонот на корисниците.

Трговците на мало, лесно можат да го зајакнат својот веб-сајт и мобилна апликација со аугментирана реалност. Брендовите, можат да ги прикажат своите производи во аугментирана реалност преку сајтовите / апликациите на нивните партнери за малопродажба.

Augment има вграден AR Viewer кој може да се додаде на постоечките iOS или Android апликации на компаниите. Овозможува персонализирање на корисничкиот интерфејс, според потребите и идентитетот на брендот. 
Augment има три опции за компаниите кои сакаат да имплементираат аугментирана реалност - основен, професионален и корпорациски план. Основниот план не ги поддржува повеќето важни функционалности, па затоа и не го препорачувам за користење. Корпорацискиот план ги поддржува сите функционалности, но е најскап - 59 евра месечно по активен уред, а треба да има минимум 10 активни уреди за да се користи. Најсоодветно решение е професионалниот план, кој ги поддржува најголем број од функционалностите и е достапен за само 25 евра месечно, што реално е доста прифатлив план за додадената вредност која им ја нуди на трговците.

Освен овие планови, Augment е достапна бесплатно за едукативни цели, но со многу ограничени функционалности. Исто така Augment е достапна и за E-commerce цели за мали бизниси, производители и малопродажба, каде што најниската цена е од 89 евра месечно по домеин, па нагоре. Овие опции се соодветни за големи малопродажни ланци кои сакаат да прикажат поголем број на производи во аугментирана реалност и да добијат многу дополнителни опции.

За мојата магистерска работа, јас ќе ја имплементирам аугментираната реалност со професионалниот план на Augment, кој е достапен за 25 евра месечно.

\section{1 Прифатливи ЗД формати за Аугмент}

За најдобро прикажување на 3Д моделите Augment препорачува да се користат ОВЈ или DAE формати.

Подолу се спецификациите за овие формати. На Augment Manager треба да се прикачи ZIP датотека со вклучен 3 Д модел, текстури и материјали:

- DAE фајл: компресирана ZIP датотека која вклучува .dae (Collada 1.4+) + текстури; или само .zae датотека.

- ОВJ: компресирана ZIP датотека која вклучува .obj (Wavefront) + .mtl (материјали) датотека + текстури

За .obj форматот потребно е да биде поврзан .mtl (библиотека на материјали) за поврзување на текстурите со моделот. Опцијата треба да се штиклира при експортирањето за да се овозможи креирање .mtl. Друга опција при експортот треба да овозможи врски на текстурите во материјалите. Мора да се има во предвид дека .mtl не ги вградува текстурите; туку ги вклучува само поставувањата на материјалите и линковите кои упатуваат на текстурите во соодветните материјали. Текстурите мора да бидат вклучени во папката.

Форматот .obj од некои $3 Д$ софтвери не може правилно да ги извезува поставките за рефлексија, па затоа треба да се проверат материјалите по експортот. 
Димензиите мора внимателно да се проверат при отворање на OBJ фајлот во Augment, бидејќи единиците и димензиите може да се сменат од оние во оригиналниот софтвер за време на експортот. Димензиите на ЗД моделот во секој момент и на многу едноставен начин можат да се променат во Augment Manager.

Дури и ако не се експортираат добро текстурите и материјалите во Augment, тие на многу лесен и брз начин можат да се додадат преку бесплатната Augment Desktop програма, како и да се додадат нови текстури, материјали и бои на моделот.

Покрај овие формати, може да се користи и STL формат.

- STL: овој формат може да се користи, но нема да ги прикажува текстурите и материјалите. ЗД моделот ќе биде прикажан без материјали и текстури, па текстурите и материјалите ќе треба рачно да се додадат во програмата Augment Desktop.

Останати ЗД формати кои можат не целосно да се имплементираат во Augment ce:

- Sketchup \& 3D Warehouse : KMZ

- Photo Scene Editor : PLY (color)

- Catia : Catia plugin to export in Collada 1.4 (.dae)

- VTK : PLY

Конкретно за мојата магистерска работа се одлучив да искористам .ОВЈ ЗД модели, кои без проблем се прикачиуваат на Аугмент. ЗД моделите кои ги искористив беа од студенти од Машински фактултет, УКИМ, Скопје, како и бесплатни ЗД модели за користење од страните free3d.com и turbosquid.com.

\section{2 Повеќе информации за ЗД моделот за прикачување во Augment}

Мобилниот уред не е толку моќен како професионален компјутер, па затоа 3Д моделот за имплементација во Augment треба да почитува одредени насоки во однос на вкупниот број на полигони, број на објекти и големината на датотеката со цел да работи беспрекорно во аугментираната реалност.

\subsection{1 Број на полигони}

Иако Augment нема фиксен лимит на бројот на полигони, поради можностите на паметните телефони препорачливо е ЗД моделот да има колку може помалку полигони. 
Препорачливо е да има помалку од 1 милион полигони, добро е да се имаат 300.000 полигони, но се преферираат помалку од 150.000 полигони.

\section{Како да се намали бројот на полигони}

Додека се создава ЗД моделот, ако се увезат предмети од CAD софтвери (Solidworks, Rhinoceros, итн.), треба да се проверат параметрите за импортирање. Ако софтверот овозможува треба да се намали густината на мрежата (или да се направи полесена мрежа за NURBS). Треба да се отстранат и двојните страни на полигонот (поради увозот на двострани нормали). Можноста да се направи ова зависи од софтверот и форматот на фајлот кој се импортира.

Ако ЗД софтверот кој се користи го дозволува ова, треба да се отстранат параметрите за измазнување кои ја зголемуваат густината на мрежата .

Треба да се провери и дали 3Д моделот има скриени полигони (во непроsирни објекти) кои лесно може да се избришат, или да не има полигони кои се преклопуваат, овие не се неопходни, а можат да создадат проблеми при прикажувањето.

Кога е можно, ситните детали најдобро е да се направат со текстури наместо со мрежата.

\subsection{2 Број на објекти}

Количината на објекти и елементи може да го спречи моделот да се прикачи или прикаже во Augment кога има илјадници објекти.

Треба да се контролира и бројот на мрежи. Како што се зголемува количината на графички елементи на сцената, исто така се зголемува и времето за вчитување. Бројот на објекти не е само бројот на мрежи, туку ги зема во предвид и различните комбинирани елементи на објектот. Спојувањето на објекти без врски помеѓу различните мрежи нема да ги подобри перформансите (и драстично го зголемува времето за експорт на DAE на некои ЗД софтвери, во зависност од сложеноста на моделот). За комплексни модели со многу објекти, се препорачува кога е можно мрежите да се поврзат заедно.

\subsection{3 Материјали}

Дозволени се само стандардни материјали; 
- Рефлексија: Треба да се избегнува користење на рефлексија на максимално ниво, и да се преферира помала рефлексија од 99\%. Во Augment, 100\% рефлексијата е поставена да биде еквивалентна на 10\%, бидејќи во многу 3Д софтвери, стандардно моделот се експортира со максимална рефлексија, па корисниците добиваат $100 \%$ метални модели без да разберат зошто.

- Сјајност: Додавањето на сјај може да создаде лесни артефакти на моделот ако мрежите се ретки, елементите со висока сјајност треба да имаат поголема густина на мрежите.

- Спекулар: Спекуларното ниво (отсјај) и боја се спојуваат во Augment, како во некои ЗД софтвери. Во зависност од ЗД софтверот кој се користи, однесувањето може да се тестира за да се избегне дивергенција во последниот изглед.

- Амбиент: Амбиентот засега не е достапен во Augment.

- Осветлување: Augment користи само една динамична светлина. Положбата на светлината е од горе.

\subsubsection{1 Експортирање на материјали}

Поддржаните формати не експортираат материјали кои се соодветни за специфичен coфтвер, plugin или рендерирање. Поради ограничувањата на експортот на 3Д софтверите и на разновидните ЗД софтвери што можат да се користат за изработка на модели, во Augment се работи само со стандардни материјали.

За да се спречи губење на материјалите и поврзаните текстури, мора да се провери дали моделите користат само стандардни материјали.

Исто така, се препорачува внимателно да се провери како различните материјали се однесуваат по експортот, бидејќи толкувањето на поставките за материјали варира многу во зависност од користениот 3Д софтвер. Можно е да бидат потребни некои дополнителни прилагодувања.

\subsection{4 Текстури}

Поддржани формати: PNG, JPG (или JPEG), BMP и TGA.

Ограничување на големината: Вкупната големина на сите текстури на моделот не треба да надминува 25 МВ. Максималната големина на текстурата е 2048x2048px; Ако големината на текстурата надминува $1024 \times 1024$ px, ќе се појави предупредување за време на поставувањето. 


\subsection{5 Големина на фајлот}

ZIP фајлот кој се поставува на Augment не смее да надминува 100MB.

\section{3 Имплементирање на Solidworks ЗД модели во Augment}

Одлучив да користам неколку ЗД модели изработени во програмата Solidworks од студенти на Машински факлутет, УКИМ, Скопје, за да илустрирам како би се имплементирале во Augment.

Бидејќи Augment не ги поддржува ЗД форматите на Solidworks, има две опции за имплементирање на ЗД моделите во Augment Desktop програмата, за нивна подготовка за имплементирање во Augment Manager и конфигурирање на различни материјали и бои.

\subsection{1 Прв метод}

Првиот метод е зачувување на Solidworks моделот во STL формат, со тоа што треба да се зачуваат сите делови од ЗД моделот во еден фајл. Тоа се прави така што при зачувување се одбира STL формат, потоа се кликнува на Options и се штиклира полето „Save all components of an assembly in a single file“, како што е прикажано на сликата подолу.

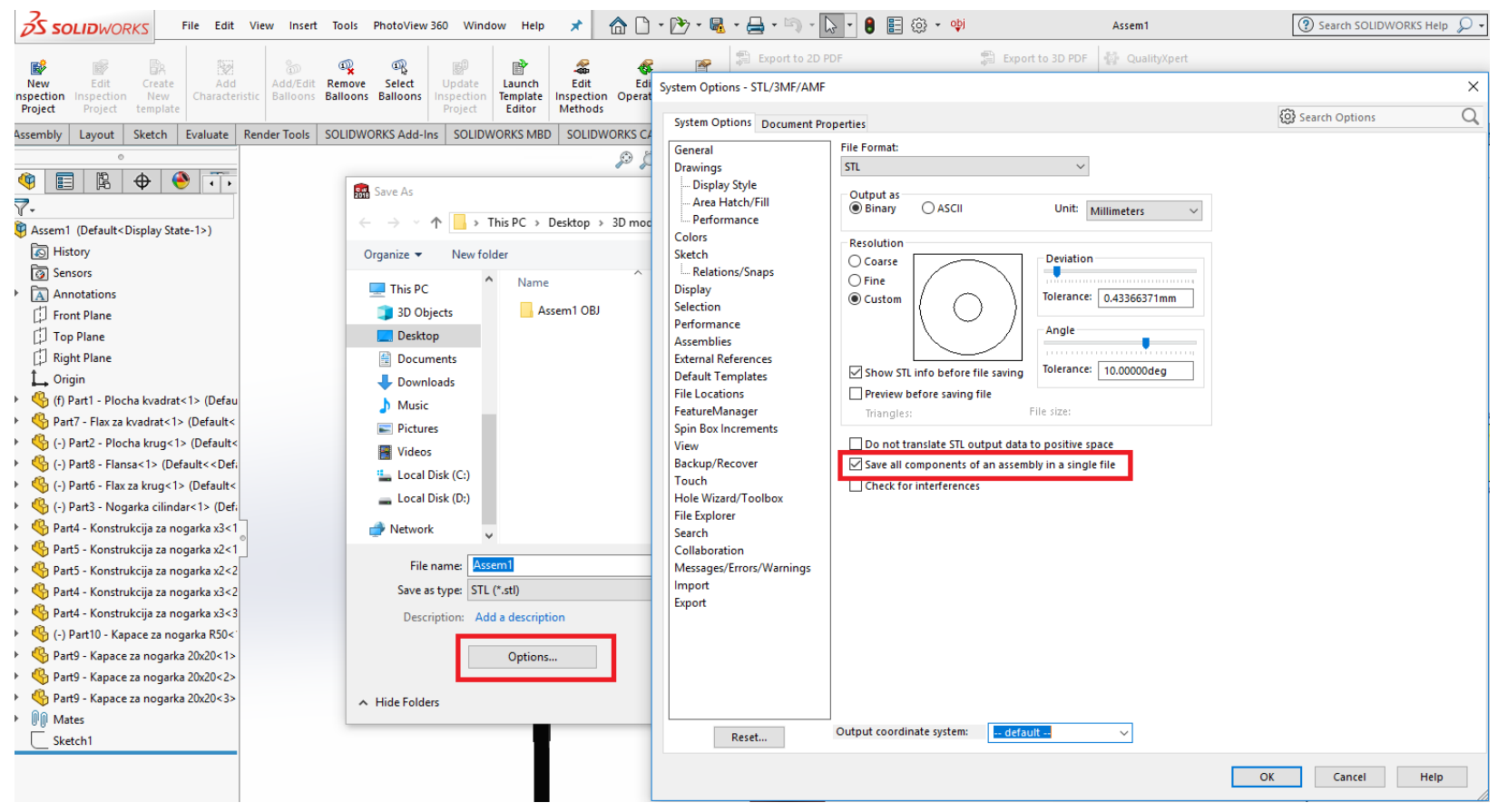

Слика 15 - Зачувување на Solidworks 3Д модел во STL формат 
Потоа овој формат може да се имплементира во Augment Desktop апликацијата.

Ha STL фајлот на многу лесен и едноставен начин можат да се додадат материјалите и текстурите, по што со кликање на само едно копче моделот се прикачува во Augment.

Недостаток на овој метод е тоа што не можат да се стават различни материјали или бои на различни делови од еден модел, бидејќи сите делови на моделот се зачувуваат како еден фајл. Текстурата или бојата која ќе се додаде во Augment Desktop се поставува на целиот ЗД модел, а не на поединечни делови, што го прави овој метод несоодветен за користење, освен за одредени ЗД модели кои се целосно изработени од ист материјал и боја.

Затоа се одличив да го користам вториот метод, објаснет подолу.

\subsection{2 Втор метод}

Како посоодветен метод за прилагодување на Solidworks моделите за нивна имплементација во Augment, кој ќе ги зачува сите опции од моделот, како и опциите за прилагодување на различни бои и материјали за различни делови од моделот е преку додавање на Obj converter Macro на Solidworks. На овој начин се овозможува експортирање на Solidworks ЗД моделите во ОВЈ формат, кој е соодветен за импортирање во Augment Desktop програмата.

Macro-то може да се симне од официјалниот форум на Solidworks, на следниот линк https://forum.solidworks.com/thread/54270.

Многу е едноставен за поставување, а подолу ќе ја објаснам постапката:

Од горенаведениот линк се симнува фајлот Free SolidWorks OBJ Exporter v2.zip

Потоа се отвора ЗД моделот во Solidworks, па се оди во Options - Customize, како што е прикажано на сликата подолу:

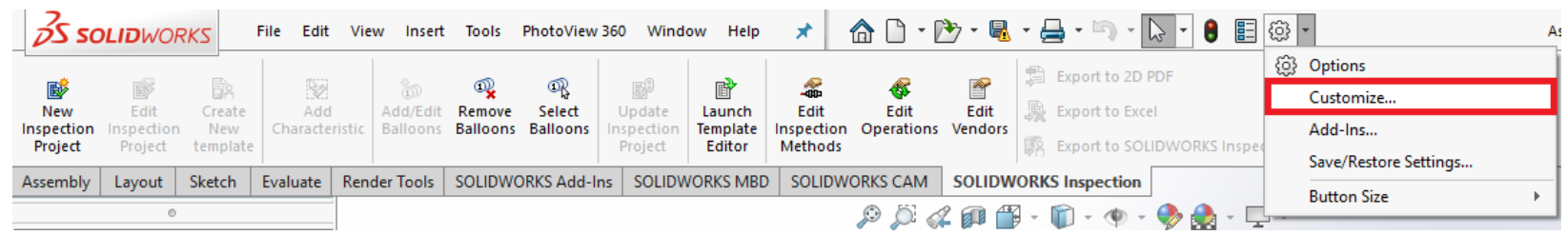

Слика 16 - Додавање на ОВJ converter Macro на Solidworks - чекор 1

Се одбира полето Commands, па Macro, како што е означено со црвено на слика 17. 


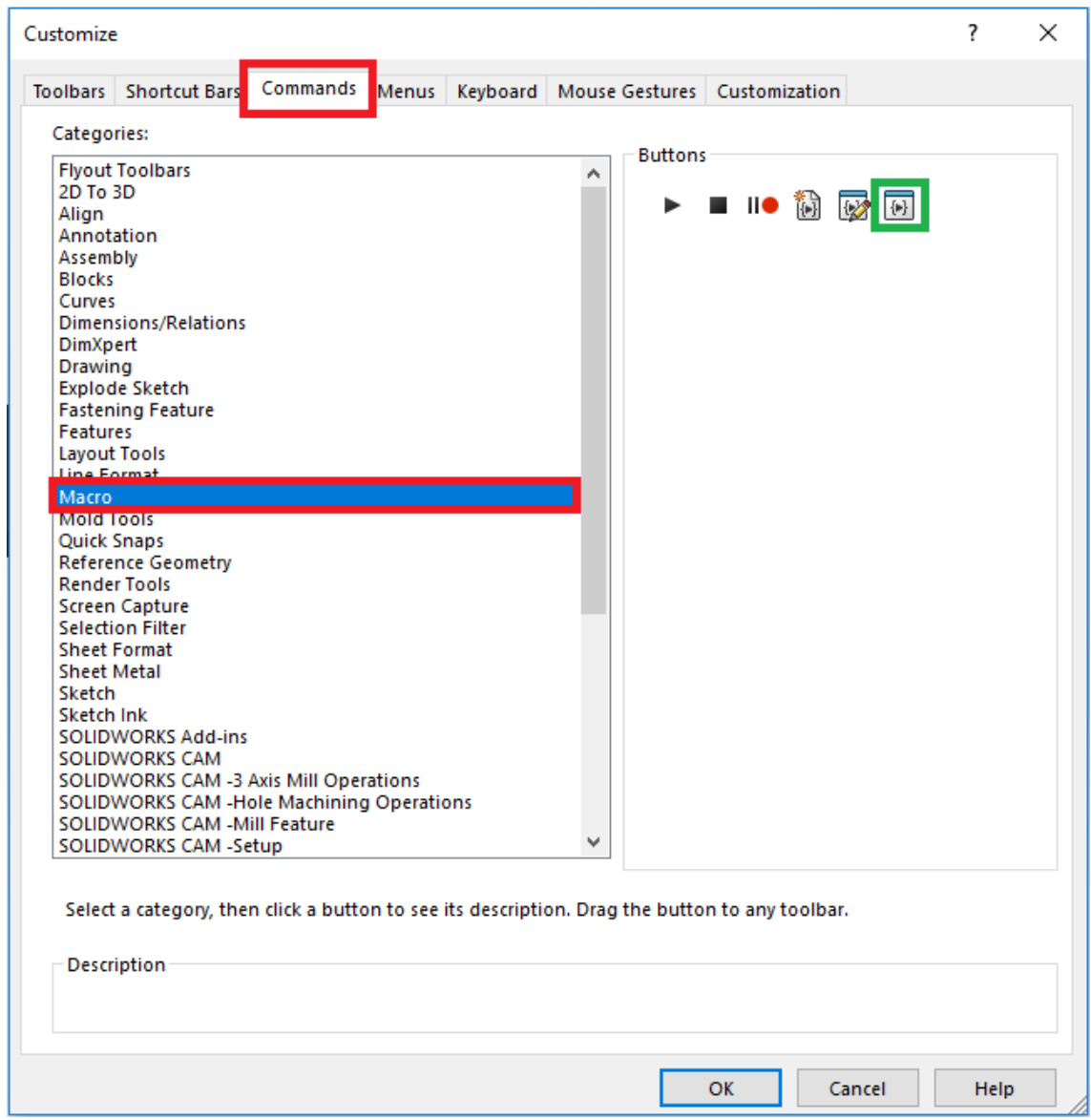

Слика 17 - Додавање на OBJ converter Macro на Solidworks - чекор 2

Потоа на истиот прозор, се кликнува на копчето New Macro Button, означено со зелено на слика 17. Потоа ова копче се влече и се поставува на менито на Solidworks, на местото каде што сакаме да стои и ќе ни биде лесно достапно.

На прозорецот што ќе се појави, се кликнува на копчето со трите точки, означено со црвено на слика 18. Потоа се отвора прозор во кој треба да го одбереме ОВЈ макрото кое го симнавме од форумот на Solidworks. Името на фајлот е Free_SolidWorks_OBJ_Exporter_v2.0.swp, означено со зелено на слика 18. 


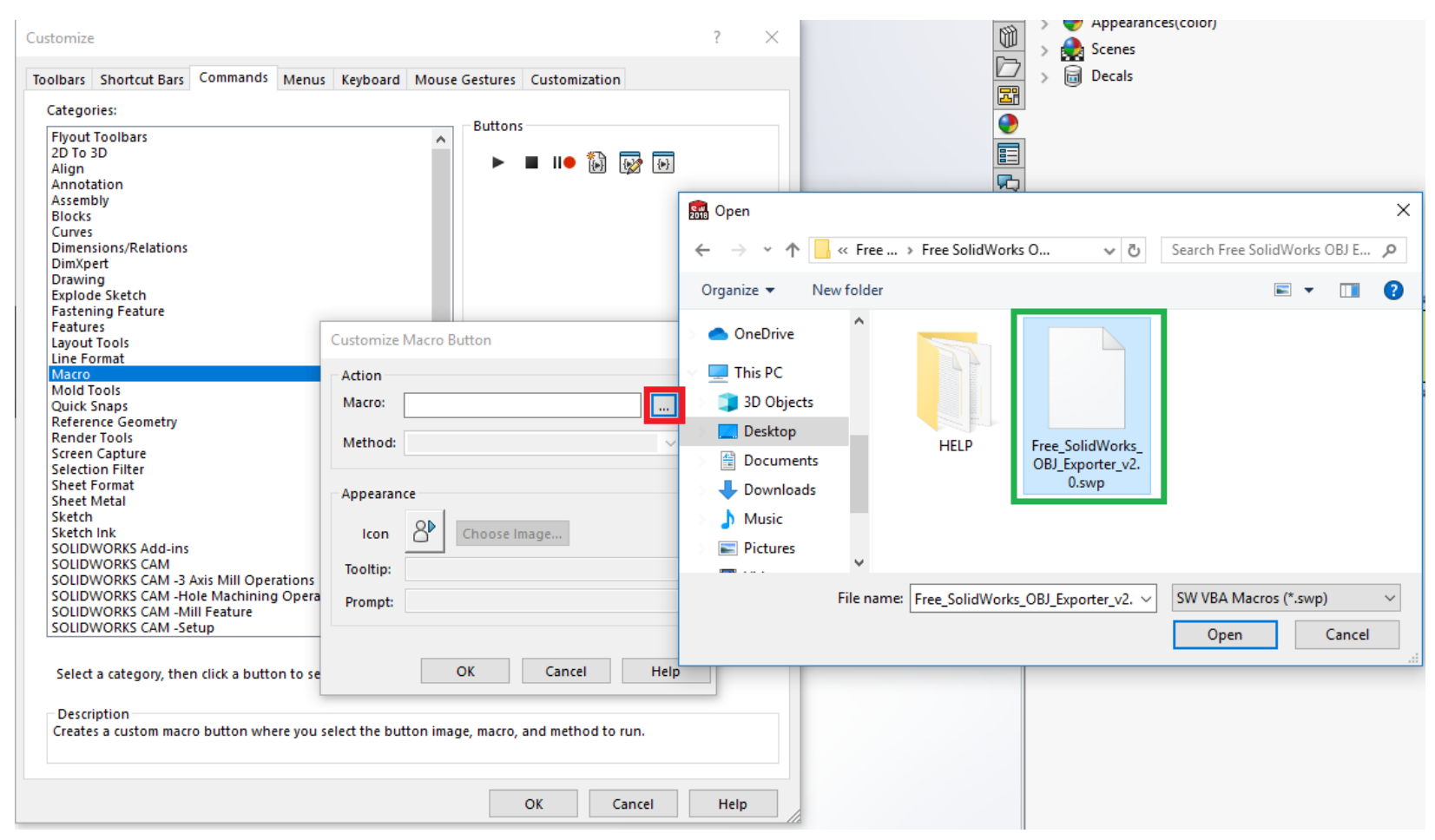

Слика 18 - Додавање на OBJ converter Macro на Solidworks - чекор 3

Потоа во делот Appearance - Icon, кликнуваме на копчето Choose Image, означено со црвено на слика 19. По што се отвора прозор, каде ја селектираме сликата од папката која ja симнавме од форумот - objicon.bmp, означена со зелено на слика 19.

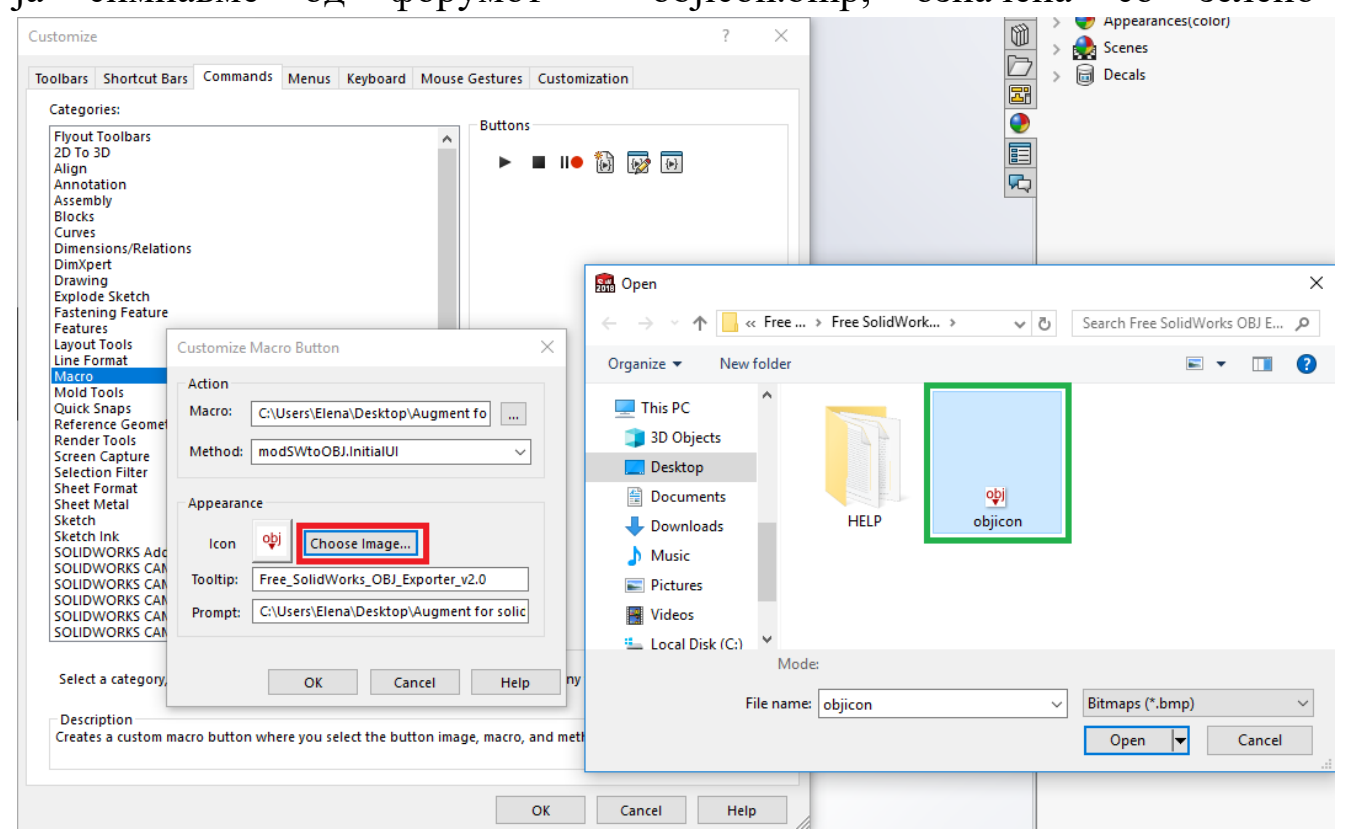

Слика 19 - Додавање на ОВJ converter Macro на Solidworks - чекор 4 
По што кликнуваме OK на двата прозора (Customize Macro Button и Customize) и макрото за експортирање на Solidworks модели во OBJ формат е поставено на местото на менито во Solidworks кое сме го одбрале и ја има ОВЈ сликата која ја селектиравме.

Откако го поставивме макрото, начинот за експортирање на 3Д моделите во ОВЈ формат е многу лесен. Само го кликнуваме ОВЈ копчето означено со црвено на слика 20, потоа се отвора прозор Free SolidWorks .OBJ Exporter v.2.0, по што се кликнува на копчето RUN EXPORTER, означено со зелено на слика 20, по што 3Д моделот се експортира во .OBJ формат во нова папка, на истата локација каде што бил зачуван и SolidWorks 3Д моделот.

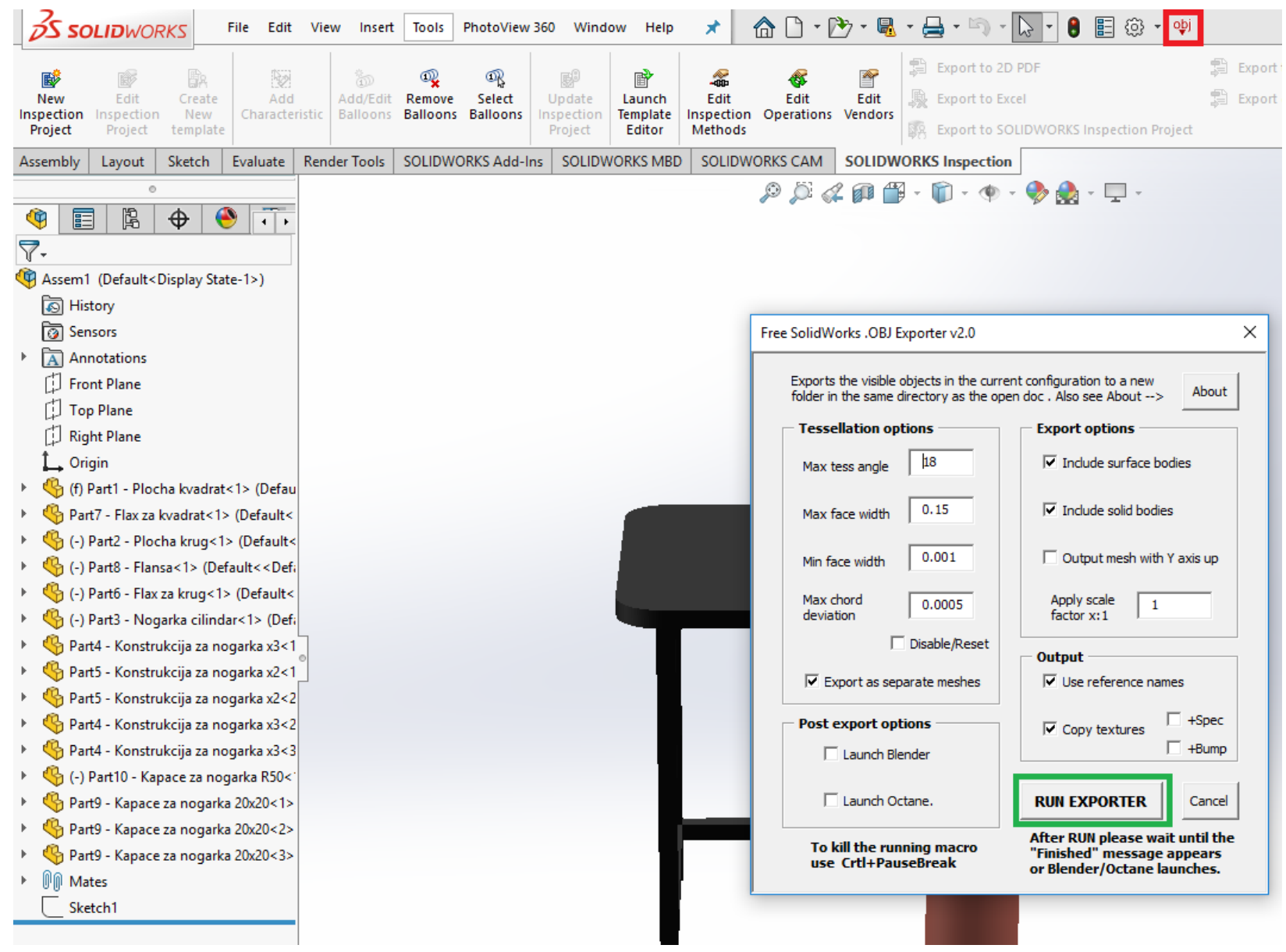

Слика 20 - Зачувување на Solidworks 3Д модел во ОВЈ формат

Во оваа папка се наоѓa и MTL фајлот и текстурите на ЗД моделот. За добра имплементација во Augment Desktop програмата, овие фајлови треба да се Zip-уваат, па Zip фајлот да се прикачи во Augment Desktop програмата. 


\section{4 Прилагодување на ЗД моделите за аугментирана реалност преку Augment Desktop програмата}

ЗД моделите во .ОВЈ формат можат директно да се постават на Augment Manager преку нивно прикачување на следниот линк https://manager.augment.com/en. во делот All Models - Add Model.

Секако претходно е неопходно да се креира Augment профил и да се одбере вид на план за плаќање помеѓу - Education, Business и E-commerce опциите.

Доколку .ОВЈ моделот се постави директно на сајтот на Augment, нема да може да се додадат дополнителни бои и текстури на производот, а може и да јави грешка и да не ги препознае материјалите и боите на ЗД моделот.

За да нема никакви проблеми при имплементацијата и да се додадат дополнителни опции за бирање на бои и текстури, ОВЈ моделот треба да се доработи во програмата Augment Desktop. Ова е бесплатна програма за обработка на ЗД моделите за приказ во аугментирана реалност, која може да се симне од следниот линк https://www.augment.com/assets/augment-desktop/Augment-Desktop-Windows.zip

По симнување на Augment Desktop програмата, процесот за прилагодување на ЗД моделите за Augment е доста едноставен и ќе го прикажам подолу.

Интерфејсот на апликацијата е прикажан на слика 21.

Главниот панел се вика Render Panel, каде што се прикажува ЗД моделот, означен е со розова боја на сликата подолу. Сите измени што се прават на моделот се прикажуваат овде. На слика 21 овој панел, како и останатите панели е празен, затоа што нема отворено ЗД модел во апликацијата. 


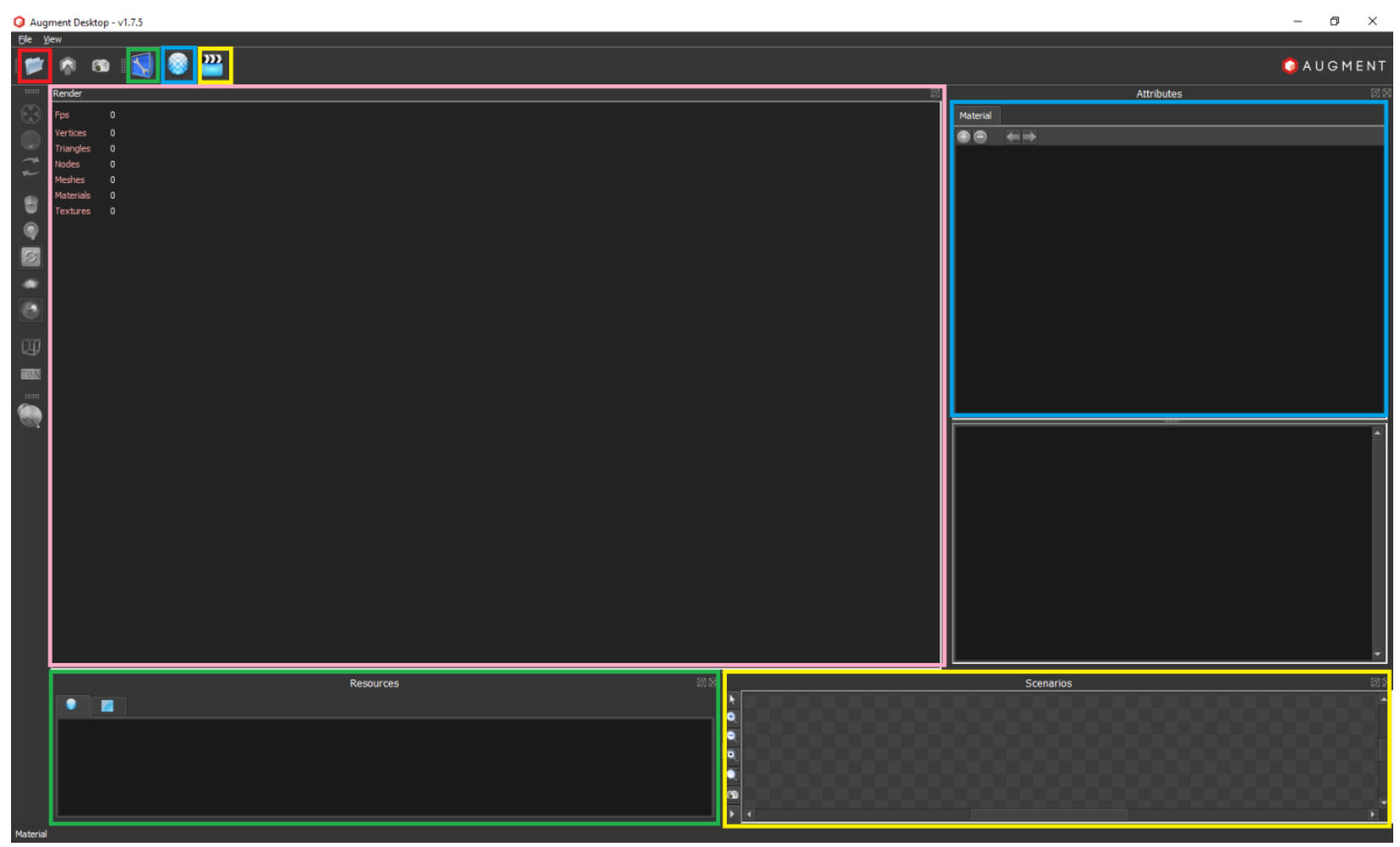

Слика 21 - Интерфејс на Augment Desktop програмата кога не е отворен ЗД модел

Има три начини за да се отвори ЗД модел во Augment Desktop програмата:

1. Со влечење на ЗД моделот од местото каде што е зачуван, во Рендер панелот на Augment Desktop

2. File - Open - избирање на ЗД моделот

3. Со кликање на иконата во форма на папка во горниот лев агол на екранот, означена со црвена боја на слика 21 и отворање на саканиот 3 Д модел.

Доколку се прикачува ZIP фајл (што е препорачливо), битно е во него да бидат вклучени obj фајлот, mtl фајлот и текстурите. Текстурите во ZIP фајлот треба да бидат именувани исто како во mtl 3Д моделот за да ги препознае. Може да се импортира и само еден фајл во формат .OBJ, .STL или .DAE, каде автоматски се повлекуваат текстурите на моделот, битно е текстурите да бидат зачувани во истата папка со моделот.

Иконата со алат, означена со зелено на слика 21 e Resources Panel. Bо овој панел има два под-панели - Материјалите на $3 Д$ моделот - кои се означени со иконата во форма на круг и Текстурите на моделот, кои се прикажани со иконата во форма на квадрат. 
Иконата во форма на круг означена со сина боја на слика 21 го отвора Attributes Panel. Кога ќе се отвори овој панел се појавуваат опциите за подесување на атрибутите на $3 Д$ моделот, каде се сетираат различните материјали, бои и останати параметри за $3 Д$ моделот.

Иконата означена со жолто на слика 21 го отвора панелот Scenarios и преку овој панел се сетираат 3Д анимации. За потребите на мојата магистерска работа, оваа опција не ми е потребна, па затоа ќе се сконцентрирам на подетално објаснување на останатите опции.

За да се подесат различни материјали и бои на одреден 3Д модел, тој треба да се отвори во програмата.

Доколку моделот или папката во која е зачуван има име напишано на кирилица, се јавува проблем, при што моделот не може да се прикачи. Затоа фајлот и папката мора да се именуваат на латиница.

По отворање на 3Д моделот и вклучување на панелите Resources и Attributes, интерфејсот на Augment Desktop изгледа вака.

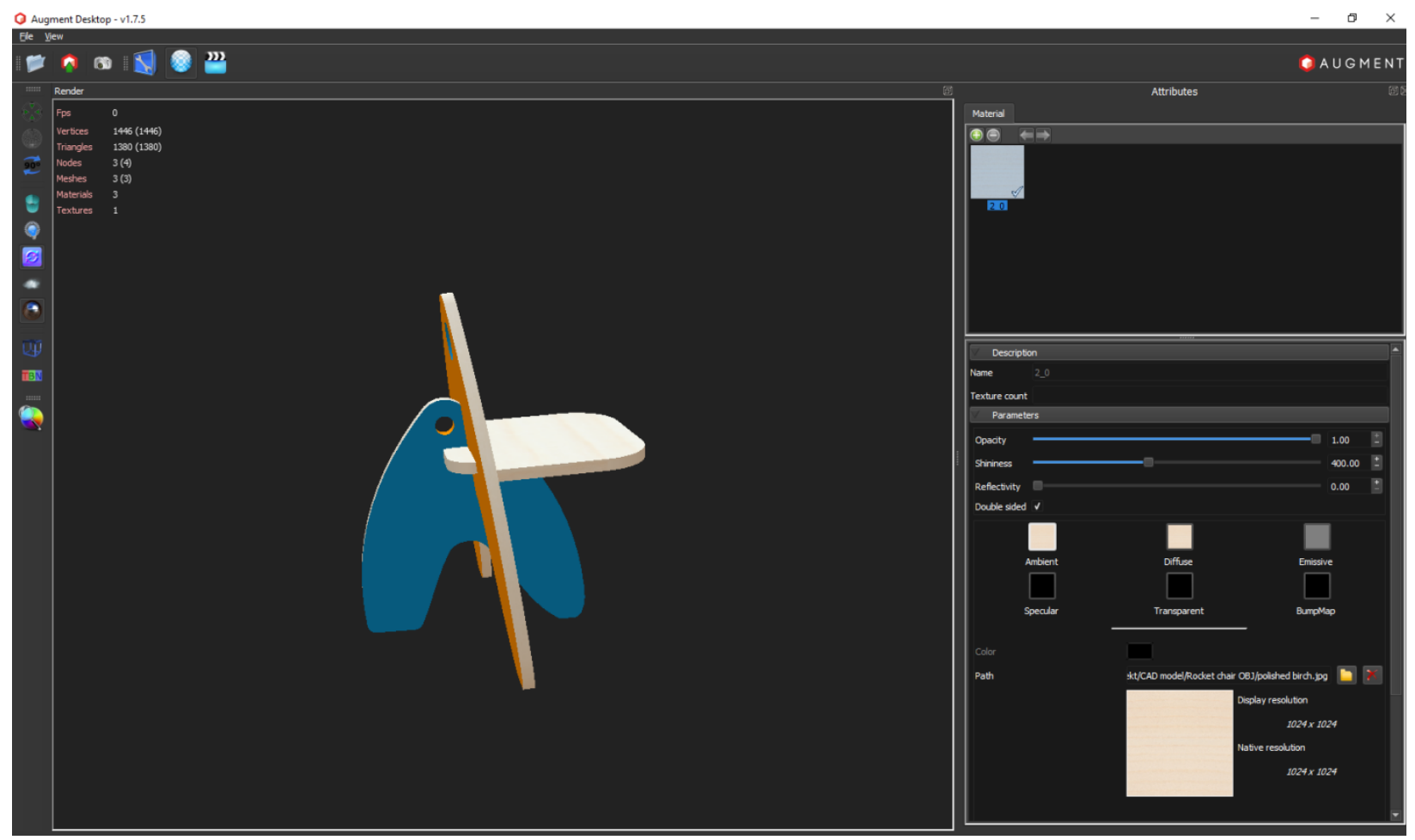

Слика 22 - Интерфејс на Augment Desktop програмата кога е отворен 3Д модел

Моделот често знае да се отвори наместен во несоодветен агол, па треба да се ротира. Ротирањето се прави многу едноставно со кликање и влечење на моделот, за да се постави 
во саканата позиција. За зумирање или одзумирање на моделот, се скрола со маусот напред или на назад.

Во горниот лев агол на Render панелот има статистики за моделот.

Во десниот агол се наоѓa Atributes Panel кој содржи два под-панели - панел за материјали и панел за параметри. Кога ќе се кликне на дел од 3Д моделот отворен во Рендер панелот, релевантните податоци за тој дел ќе се прикажат во панелот со атрибути. Во панелот за материјали ќе се прикаже селектираниот материјал на $3 Д$ моделот, додека во панелот со параметри под него можат да се прилагодат различни параметри за производот како непрозирност, сјај и рефлексија.

За да се промени текстурата на производот или на дел од производот, треба да се селектира делот од производот на кој сакаме да му ја смениме тестурата. Ова се прави со кликање на тој дел од производот (пр. делот кој го покажува зелената стрелка на слика 23 подолу). Потоа се појавуваат сите атрибути за тој дел од производот во Attribute панелот.

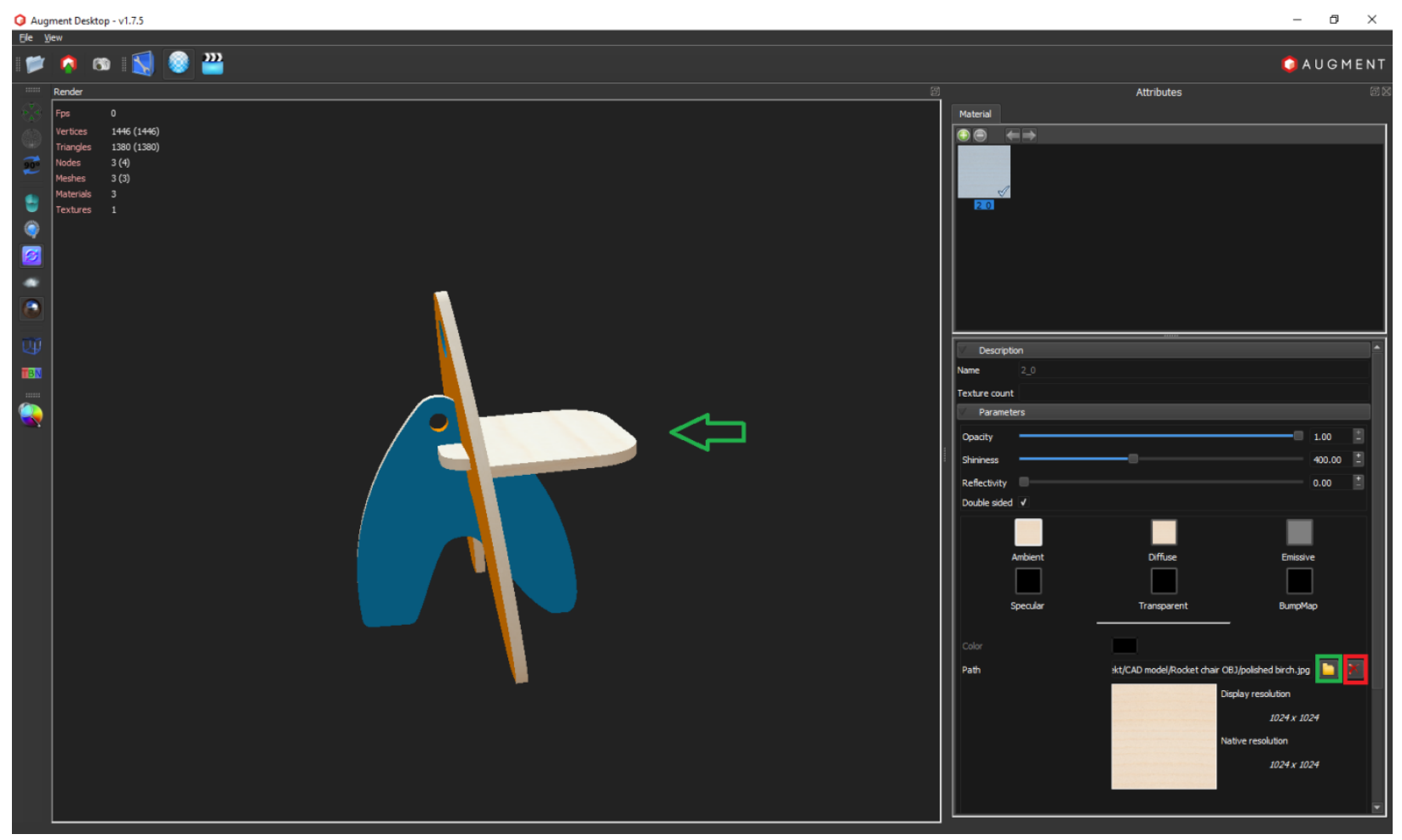

Слика 23 - Промена на текстура на дел од производ во Augment Desktop

Доколку сакаме да ја смениме текстурата на производот, во Parametars панелот, кликнуваме на X копчето, означено со црвено на слика 23, по што се отстранува постоечката текстура, а со кликнување на копчето во форма на папка, означено со зелено на слика 23, се отвара прозор преку кој ја бараме и одбираме новата текстура за моделот од фајловите на нашиот компјутер. 


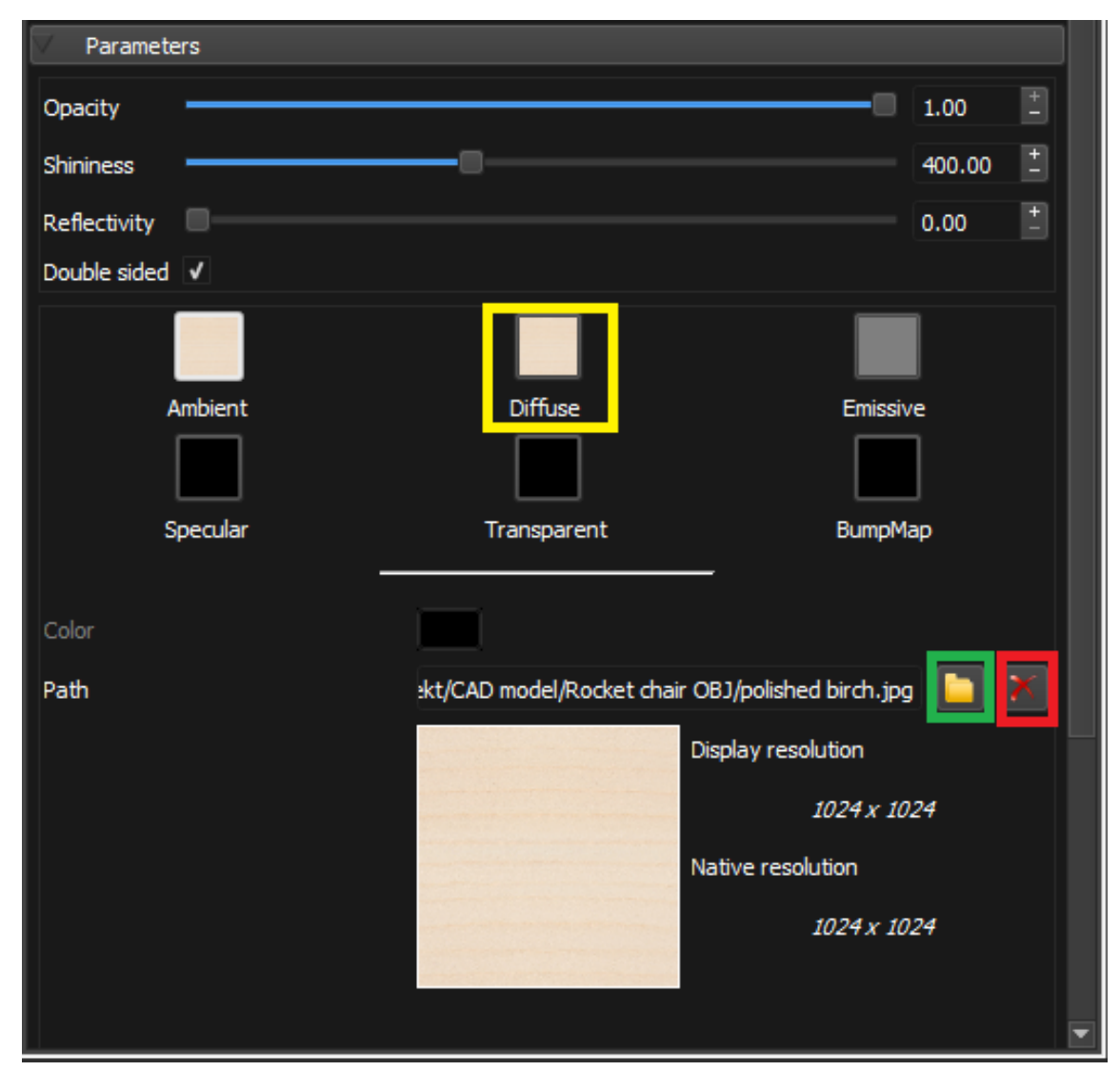

Слика 24 - Детален приказ на опцијата за промена на текстура или боја на дел од производ во Augment Desktop

Доколку не сакаме да поставиме текстура, туку само да одбереме боја за тој дел од моделот, со X копчето ја отстрануваме текстурата (означено со црвено на слика 24), па кликнуваме два пати на бојата во Diffuse полето означено со жолто на слика 24, по што се отвора спектар на бои, од кој ја одбираме бојата која ја сакаме.

Истата постапка се повторува за секој дел од ЗД моделот.

Доколку сакаме да конфигурираме повеќе материјали на ЗД моделот, кои овозможуваат да се види како производот би изгледал во различни бои или материјали, селектираме дел од производот на кој сакаме да му додадеме дополнителна текстура или боја, па одиме десно во панелот за материјали и кликнуваме на иконата со зелен + знак (означена со жолто на слика 25), по што се додадава уште еден материјал, кој е ист како веќе поставениот. 


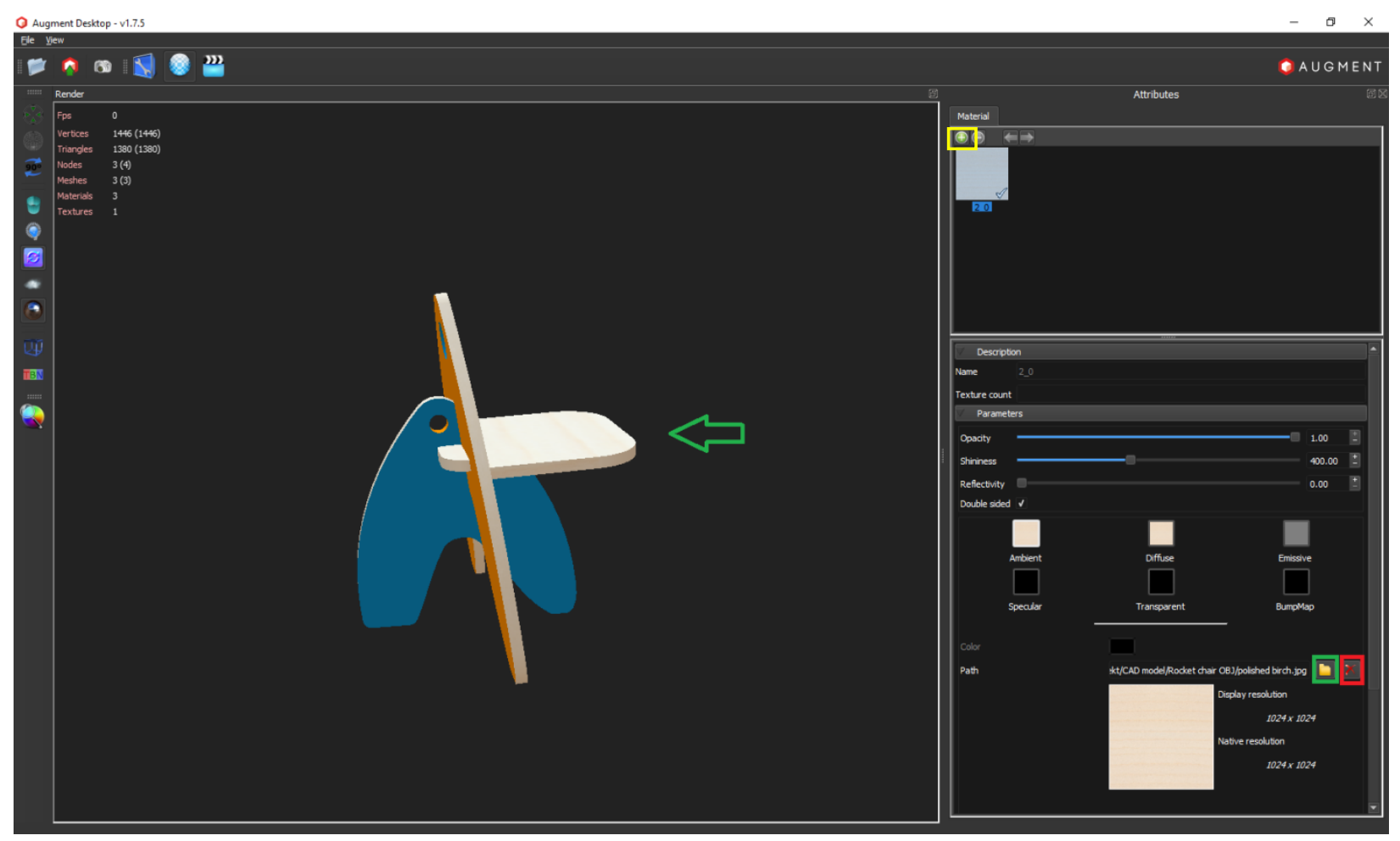

Слика 25 - Додавање на дополнителна текстура или боја на дел од производ / производ во Augment Desktop

Доколку сакаме да додадеме нова текстура, постапката е иста како покажаната погоре, ја бришеме претходната текстура со копчето X, па кликнуваме на иконата во форма на папка и одбираме нова текстура. Доколку сакаме да додадеме само нова боја на моделот, без текстура, ја бришеме претходната текстура и во полето Diffuse одбираме нова боја. Процесот го повторуваме онолку пати колку што сакаме да додадеме достапни варијанти на боја и текстури за производот. За промена на текстурата или бојата на друг дел од моделот, само го селектираме тој дел од моделот и ја применуваме истата постапка.

По завршување со прилагодување на моделот со дополнителни бои и текстури, можеме да направиме слики од различниот изглед на моделот со различни комбинации на бои и материјали, со кликање на третата иконата во горниот лев дел на менито, во форма на фотоапарат (означена со црвено на слика 26) и одбираме место на нашиот компјутер на кое ќе ја зачуваме сликата, како и формат во кој ќе ја зачуваме помеѓу .PNG .JPG или .ВМР форматите. 


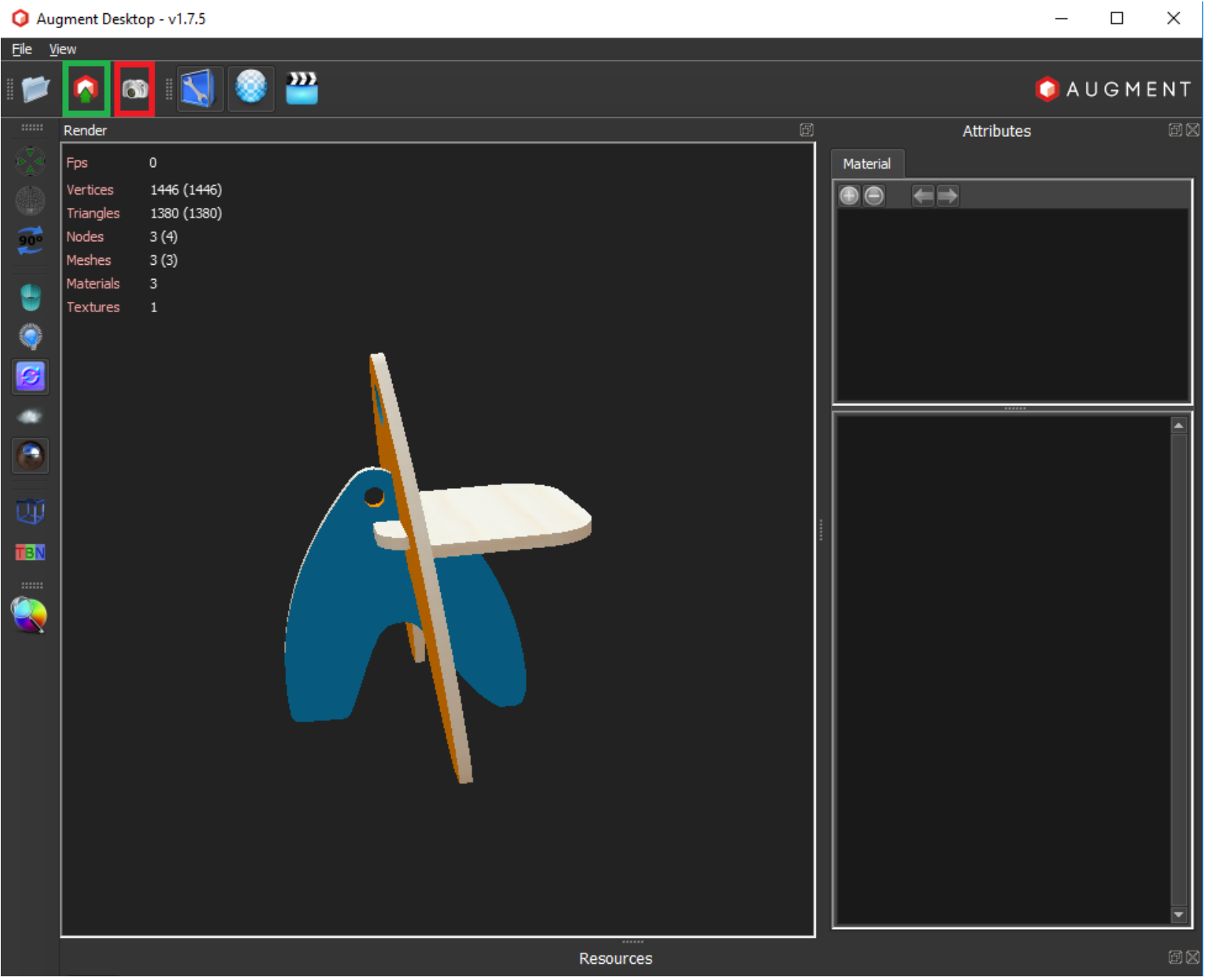

Слика 26 - Правење слики од моделот во Augment Desktop и негово прикачување на Augment Manager

Кога ќе завршиме со работа на моделот и ќе ги направиме сите неопходни слики, за прикачување на моделот во Augment Manager преку кој ќе може да се види во аугментирана реалност, кликаме на втората икона, во горниот лев дел од менито, означена со зелено на слика 26.

Доколку не сме логирани во апликацијата со нашиот username или email и лозинка, го правиме ова, за да се поврземе со нашиот Augment manager, co што ЗД моделите кои ги конфигурираме по прикачување, директно би се појавиле на нашиот профил во Augment Manager.

По кликнување на копчето Upload, го пишуваме името на моделот (на латиница или кирилица). Се одбира категорија на производот од листата со категории, па се одбира дали моделот ќе биде приватен - видлив само за нас и за оние кои ќе добијат линк од моделот или ќе биде јавно достапен на Augment апликацијата. 


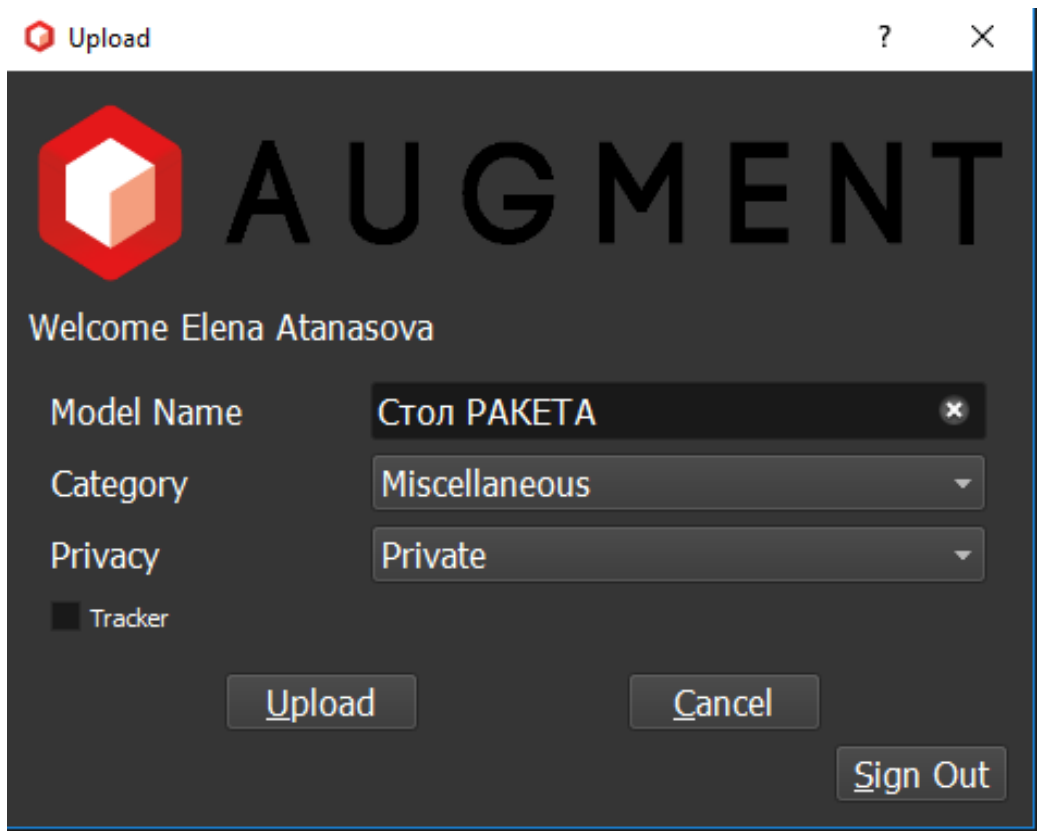

Слика 27 - Именување и прикачување на ЗД моделот од Augment Desktop во Augment Manager

Доколку сакаме да поставиме слика од производот која би служела како тракер - со скенирање на сликата во Augment апликацијата автоматски би се отворил ЗД моделот за кој се однесува - го штиклираме полето Tracker, по што го кликнуваме полето што се појавува под него и ја одбираме сликата која би служела како тракер. Доколку има потреба, ги менуваме димензиите и името на тракерот. Процесот е прикажан на слика 28.

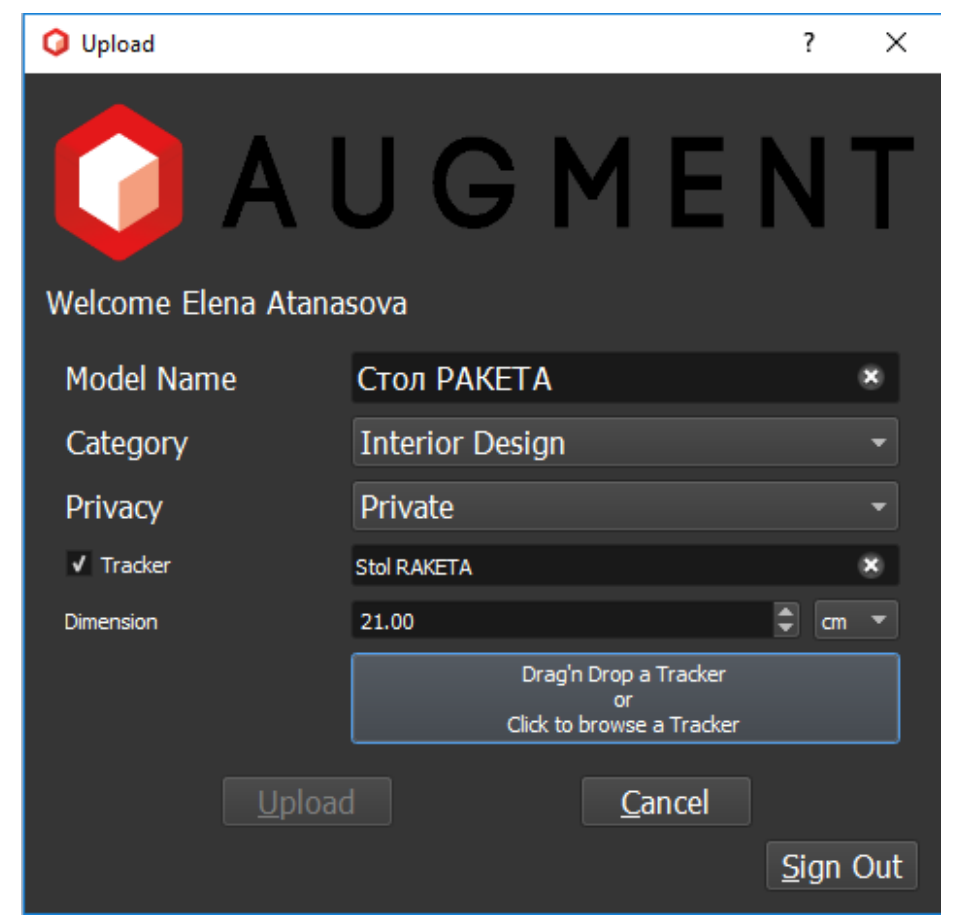

Слика 28 - Додавање на слика од производот која би служела како тракер 
За да го прифати тракерот, битно е оваа слика веќе да не е искористена како тракер за друг 3Д модел. При бирање на слика за тракер, најдобро е да се одбере слика од ЗД моделот која е негова добра репрезентација и во иднина би можела да се искористи на пример во каталог, од кој со скенирање на сликата преку Augment апликацијата, би се видел производот во аугментирана реалност.

По кликнување на копчето Upload 3Д моделот се прикачува во делот All models на Augment Manager (означен со жолто на сликата 29), по што продолжуваме да работиме таму.

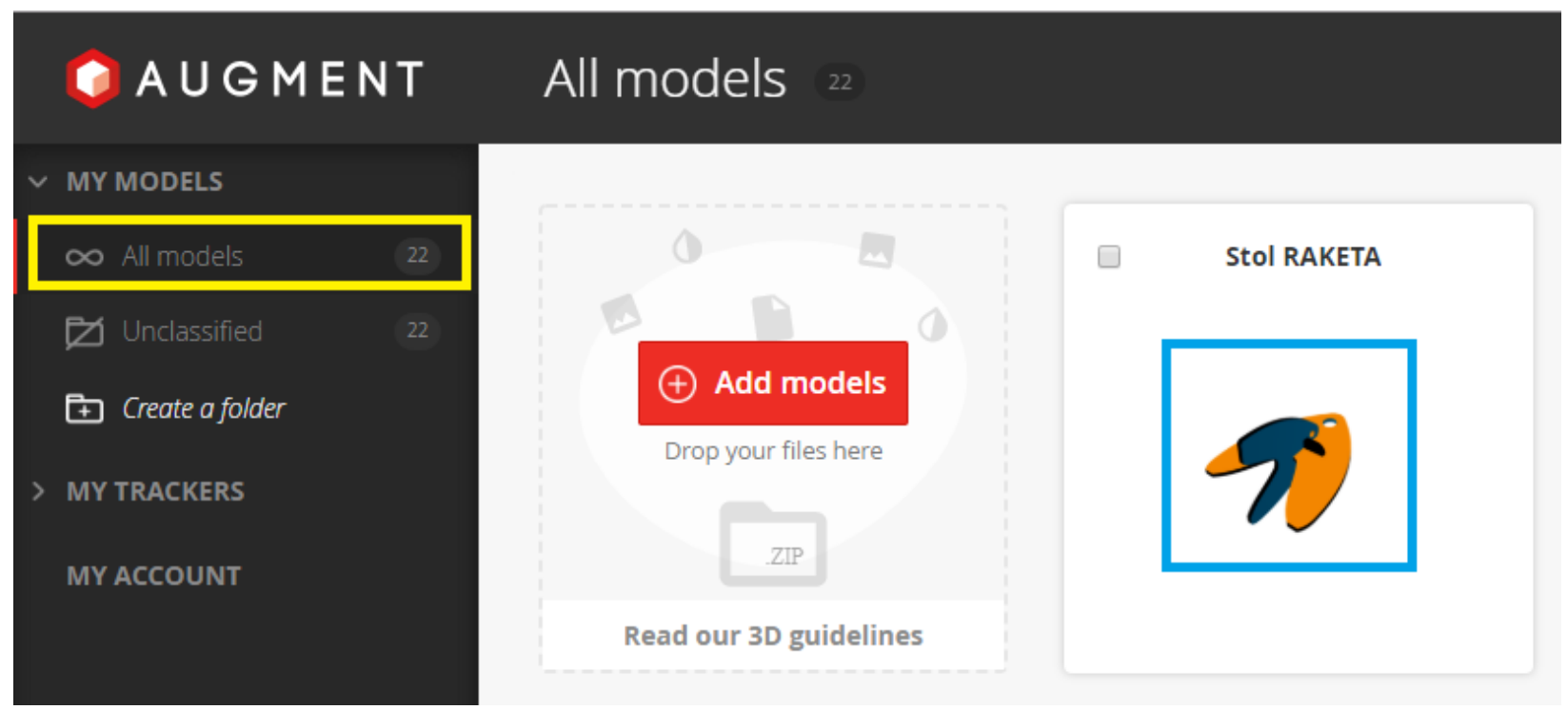

Слика 29 - Приказ на конфигурираниот ЗД модел прикачен во Augment Manager

Доколку моделот ни е наместен во добар агол во Augment Desktop апликацијата, но во Augment Manager не се појавува во соодветниот агол кој сме го одбрале, како што е во конкретниот случај со нашиот 3Д модел означен со сина боја на слика 29, кликнуваме на моделот за да го отвориме, по што кликнуваме на црвеното копче Edit означено со зелено, на слика 30. 


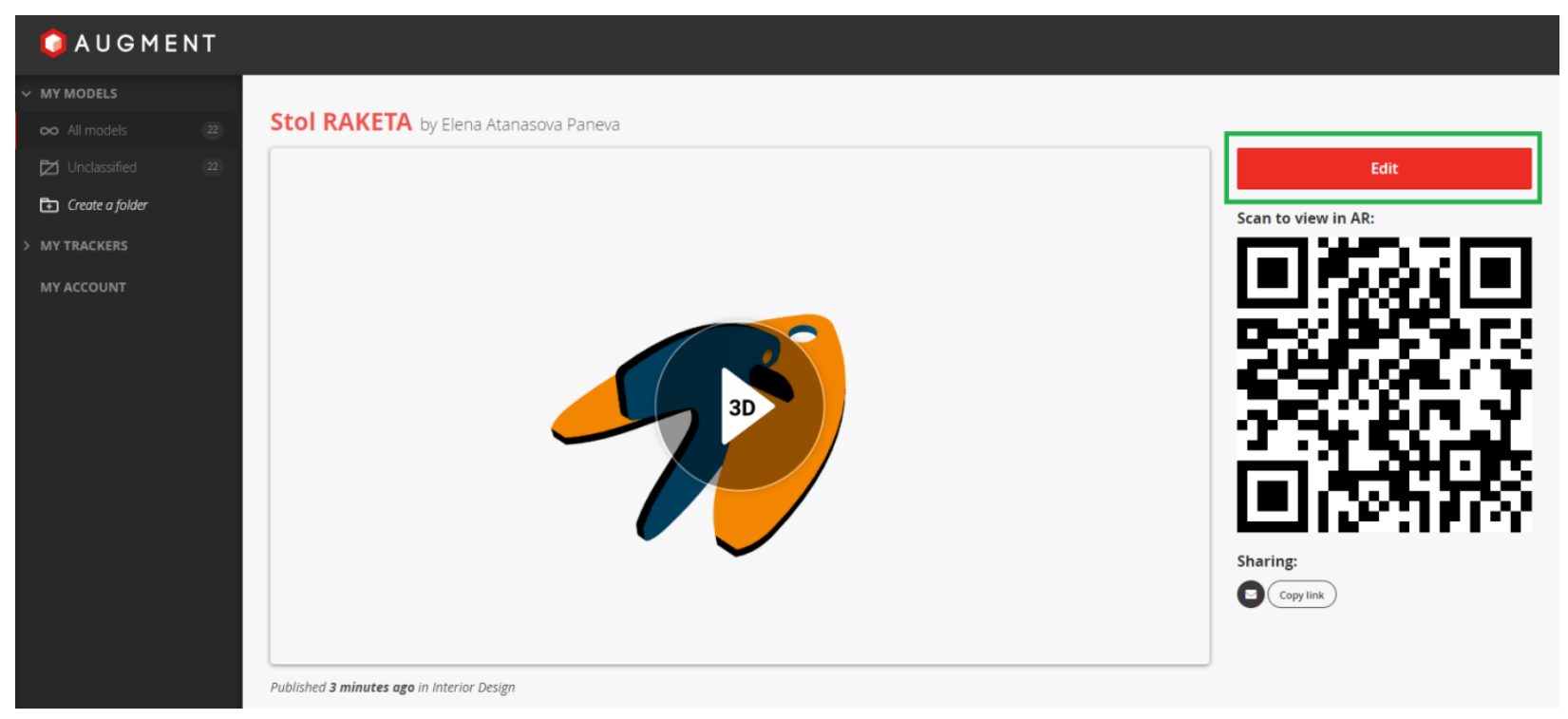

Слика 30 - Дополнително едитирање на ЗД моделот во Augment Manager

По што ни се отвора прозор во кој можеме да едитираме повеќе параметри на производот, прикажан на слика 31 подолу.

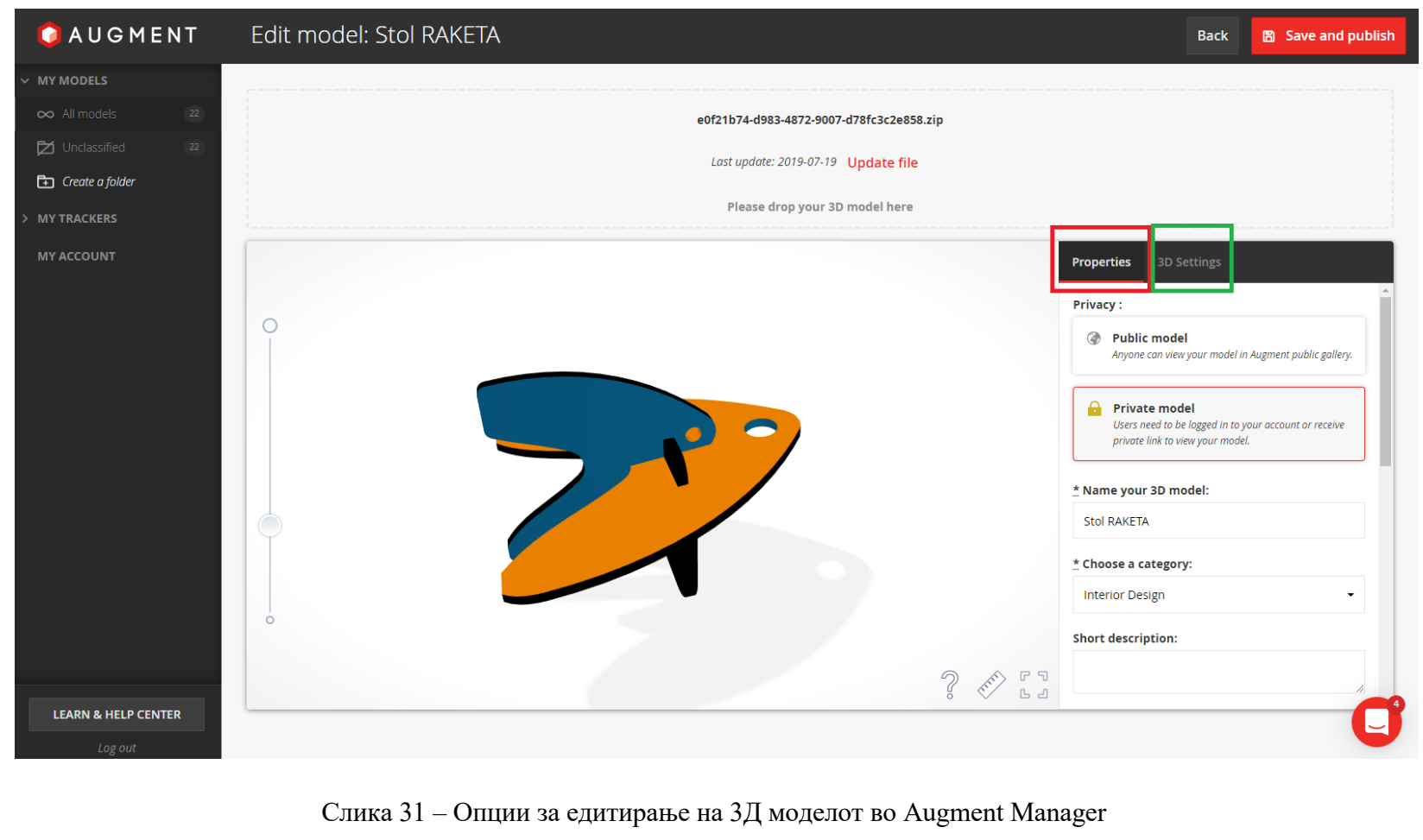

Bo Properties делот, означен со црвено на слика 31, можеме да ги промениме името и категоријата на производот, да додадеме краток опис за производот, да ја смениме сликата од 3Д моделот, да се додадат тагови за производот и да го линкуваме производот кон одредена веб страна. 
Во делот 3D Settings означен со зелено на слика 31, можат да се променат димензиите на производот и да се одбере различна мерна единица за димензии, како што е прикажано на сликата 32.

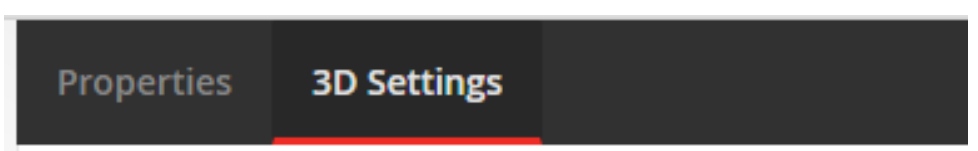

\section{Dimensions:}

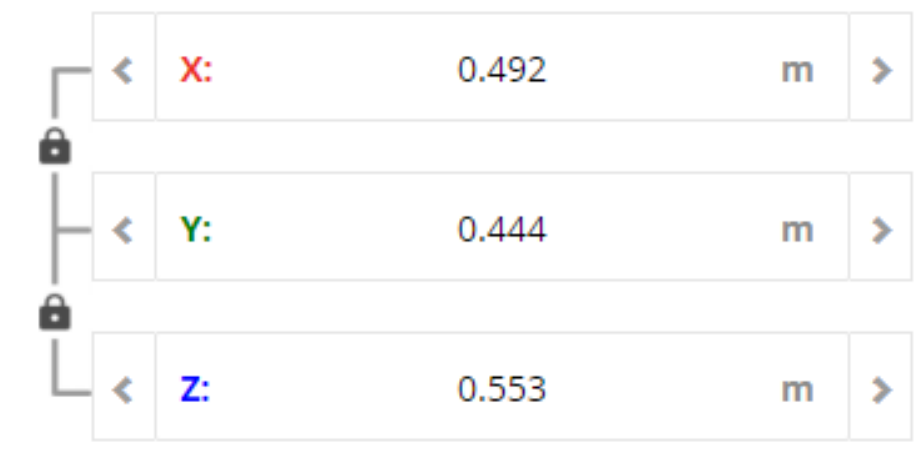

Unit:

\begin{tabular}{|c|}
\hline Meter \\
\hline Millimeter \\
Centimeter \\
\hline Meter \\
Inch \\
Foot \\
Yard \\
\hline
\end{tabular}

Слика 32 - Опции за едитирање на димензиите на ЗД моделот во Augment Manager

Многу често се случува моделот да се прикачи во погрешна мерна единица, на пример во милиметри, наместо во метри, па ова мора да се корегира овде.

Bo 3D Settings може да се прилагоди и аголот во кој се прикажува производот преку корекции на неговата ориентација на X, Y и Z оската, како што е прикажано на слика 33. 


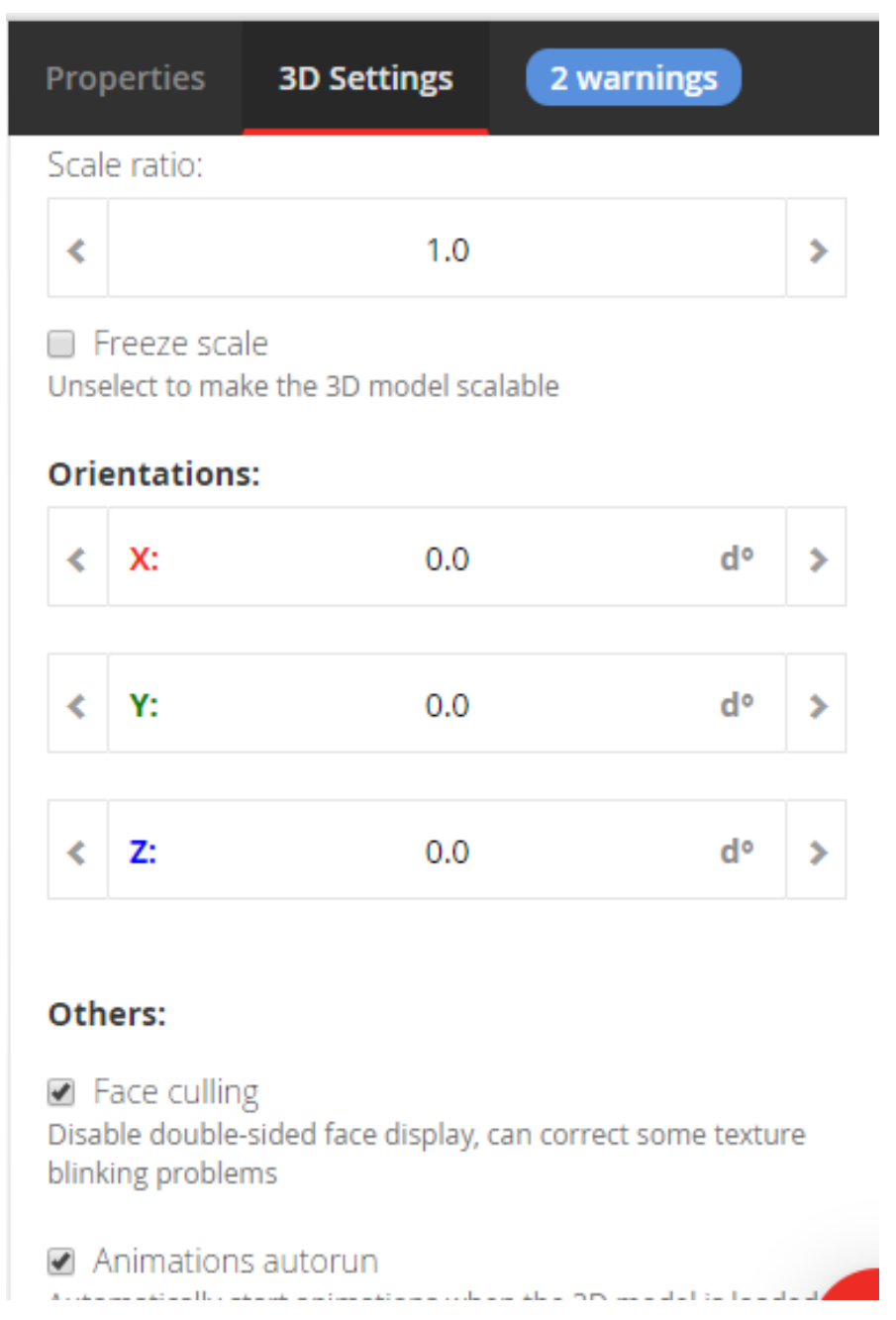

Слика 33 - Прилагодување на аголот на приказ на 3Д моделот во Augment Manager

Во конкретниот случај, ние ќе направиме корекција од 90 степени на X оската, по што кликнуваме на црвеното копче Save and publish, во најгорниот десен агол на слика 31, па ЗД моделот ќе се прикаже во саканиот агол.

По завршување со едитирањето и зачувување на ЗД моделот, кликнуваме на копчето Back, кое се наоѓ во горниот десен агол, веднаш до копчето Save and publish на слика 31, по што се враќаме на прозорот со приказ на 3Д моделот (слика 34). На овој прозор од десната страна се наоѓa QR код за скенирање на 3Д моделот за негов приказ во аугментирана реалност (означен со сина боја на слика 34). Под QR кодот, се наоѓa дел за споделување на ЗД моделот во аугментирана реалност преку копирање на линк (означен со зелена боја на слика 34) кој редиректира кон 3Д моделот во аугментирана реалност во Augment апликацијата. 


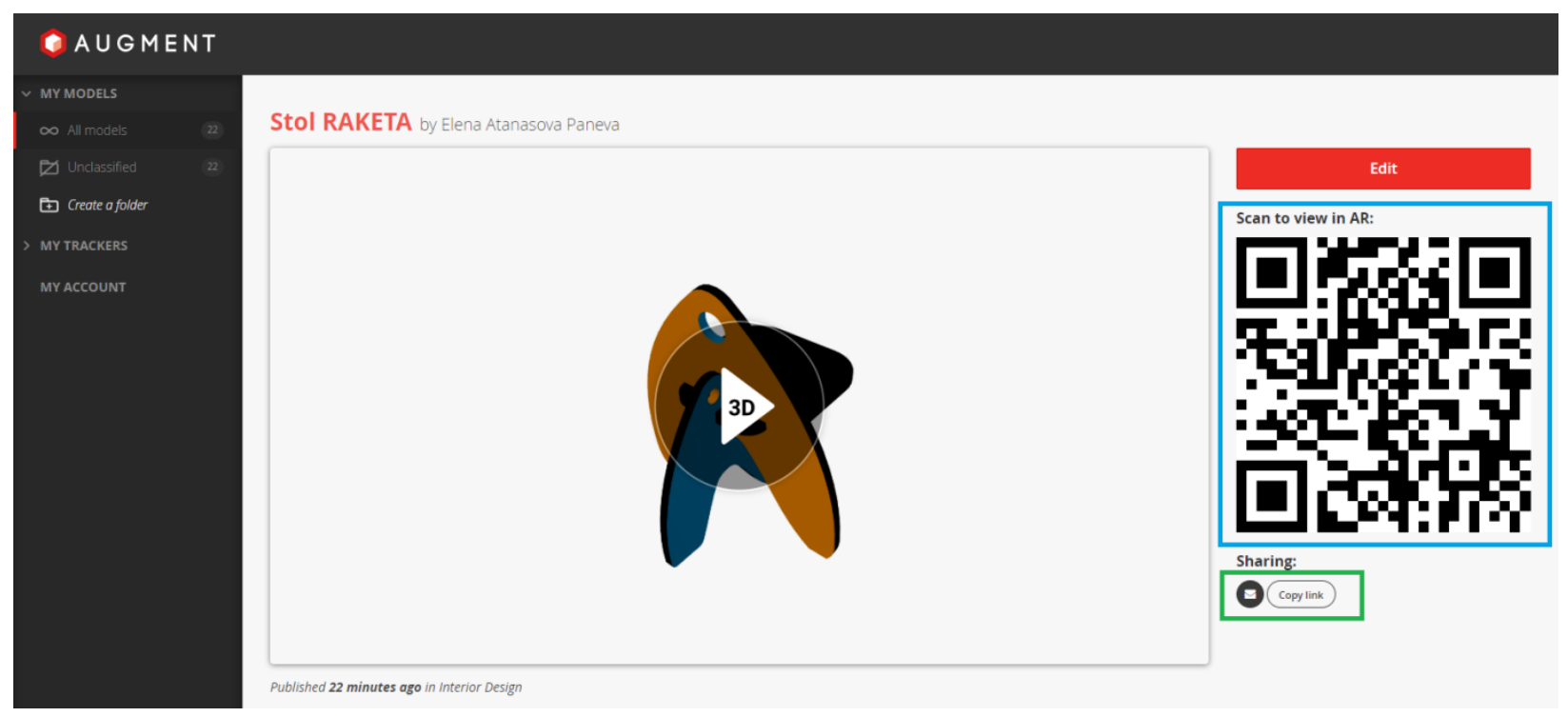

Слика 34 - Приказ на ЗД моделот во Augment Manager и опциите за негово отворање во аугментирана реалност

Преку копирање на овој линк и негово поставување на сајтот за продажба на производите, посетителите на сајтот ќе можат да го видат производот во аугментирана реалност во нивниот дом.

Со кликање на овој линк ќе бидат пренасочени кон Playstore / App store од каде ќе треба да jа симнат бесплатната Augment апликација, по што со повторно кликање на линкот производот ќе се отвори во Augment апликацијата и ќе можат да го видат во аугментирана реалност во својот дом.

\section{7. Развој на веб-сајт за малопродажба со модул за аугментирана реалност}

Во оваа магистерска работа се одлучив практично да ја применам технологијата на аугментирана реалност во онлајн продажбата. За таа цел направив вебсајт за продавница за продажба на мебел - AUGmebel, на кој производите се прикажани во аугментирана реалност. Сајтот е достапен на следниот линк augmebel.wixsite.com/home

Во аугментирана реалност имплементирав три 3Д модели на производи од студенти на Машински факултет, УКИМ, Скопје, останатите шест ЗД модели на производи ги превземав онлајн од сајтот free3d.com и turbosquid.com - кои нудат ЗД модели за бесплатно користење. 
Истражив неколку опции за бесплатна изградба на вебсајт, со цел да најдам најсоодветна опција за моите потреби. Како најсоодветен го одбрав Wix.com - кој е онлајн алатка за изработка на веб-страни, па започнав со изработка на сајтот.

Се одлучив сајтот да биде соодветен за онлајн продажба и да ги има сите опции и информации кои им се потребни на потрошувачите за да донесат одлука за купување онлајн, а воедно ќе може на лесен и едноставен начин да се имплементира аугментираната реалност.

Една од неопходните работи беше дизајнот на сајтот да биде респонзивен и да се прилагодува на различни димензии и резолуции на екран. Многу битен аспект за мојата намена е добра мобилна верзија на веб-сајтот, бидејќи аугментираната реалност пред сѐ се користи со смартфон, па затоа добар дизајн на мобилен сајт беше од круцијално значење.

Се одлучив на сајтот да понудам производи од три категории:

1. Клуб маси

2. Столици

3. Останати производи

За подобра илустрација, во секоја категорија има достапно по три производи, со информации и слики на производите, како и опција за нивно гледање во аугментирана реалност и онлајн купување.

На сајтот имам поставена хоризонтална навигација, со следните полиња:

\section{- Почетна}

- Производи - во која со паѓачко мени се отвораат трите категории на производи

- Аугментирана реалност

- Информации

- Често поставувани прашања

- За нас

- Контакт

Сајтот има привлечен, впечатлив и интуитивен дизајн, со цел да биде атрактивен за корисниците и лесен за користење.

На сликите подолу можат да се видат различни делови од дизајнот на вебсајтот AUGmebel.

Во Прилог 3 е прикажана адаптација на овој веб-сајт за потребите на Машински факултет, УКИМ, Скопје. 


\section{1 Почетна страна}

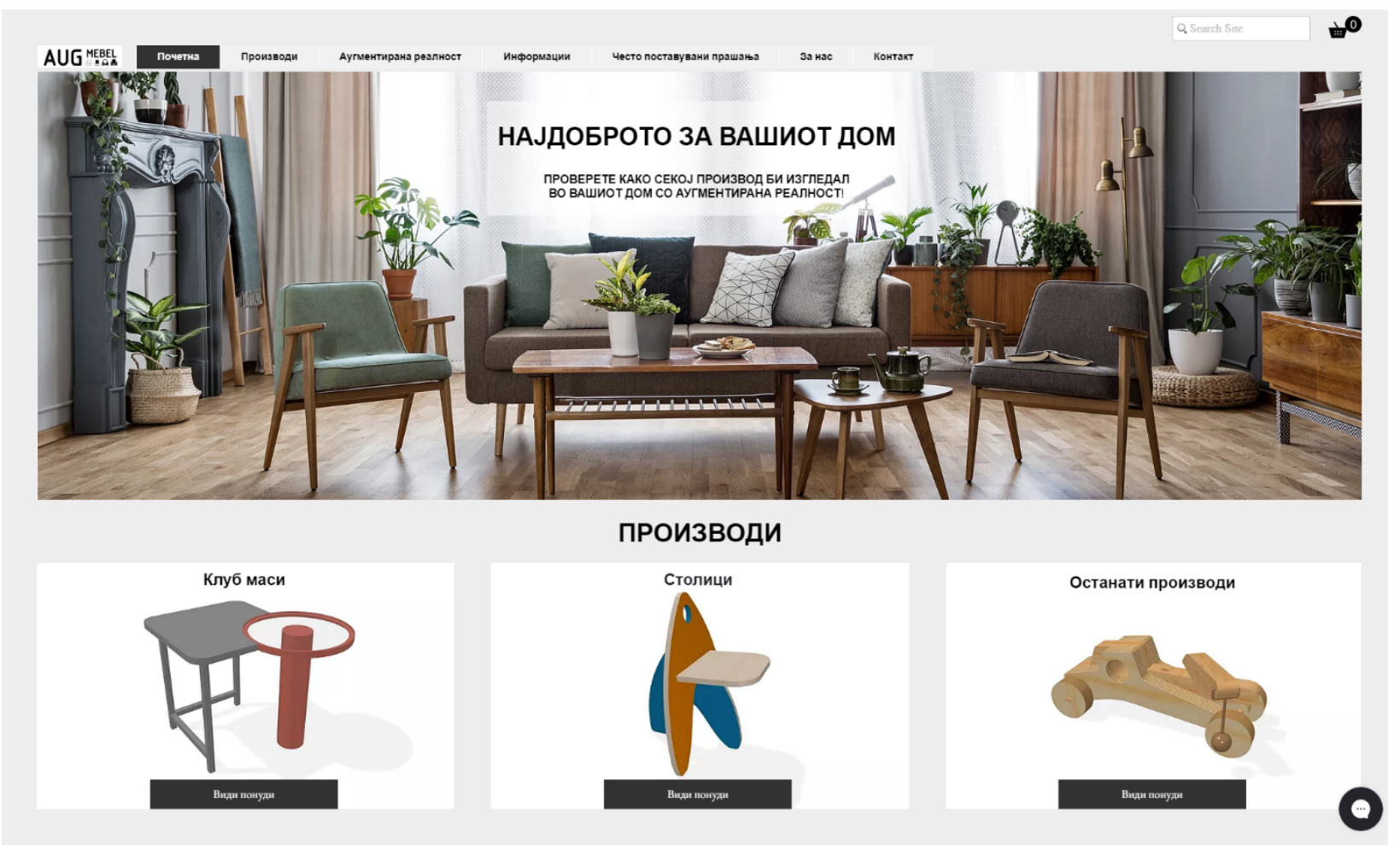

Слика 35 - Десктоп верзија на почетна страна на сајтот AUGmebel

Во левиот горен агол на сајтот се наоѓа логото на продавницата за мебел AUGmebel, кое го дизајнирав за оваа намена:

\section{AUG MEBEL}

Слика 36 - Дизајн на AUGmebel лого

Логото се појавува на секоја страна на сајтот и линкува кон почетната страна.

На почетната страна под хоризонталната навигација, се наоѓa заглавието на страната (header banner) со привлечен дизајн на модерна дневна соба. На заглавјето е испишан слоганот на компанијата - „НАЈДОБРОТО ЗА ВАШИОТ ДОМ“. Под него е нагласена главната конкурентска предност на оваа компанија, а тоа е опцијата за проба на производите во аугментирана реалност - „Проверете како секој производ би изгледал во вашиот дом со аугментирана реалност!“. 
Под заглавјето се прикажани трите категории на производи кои се нудат на сајтот: „Клуб маси“, Столици“ и „Останати производи“, со дизајн на банер за секоја категорија, на кој е прикажан еден производ од таа категорија. Во долниот централен дел на секој банер, се наоѓа копче „Види понуди“ кое линкува кон страната со сите производи од соодветната категорија.

Сајтот има респонзивен дизајн, па неговата мобилна верзија ги има истите елементи, соодветно распределени за приказ на мобилен.
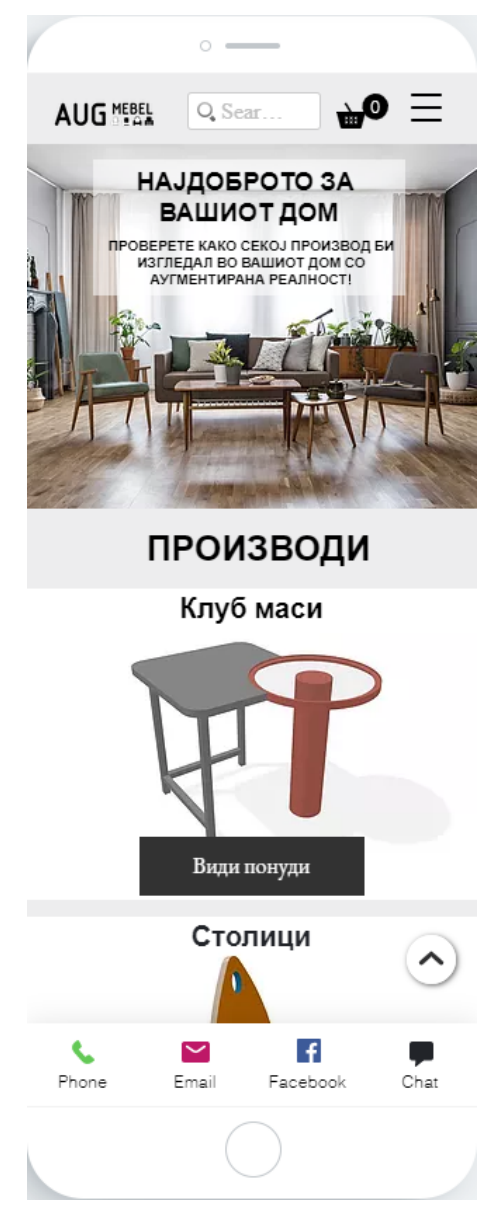

Слика 37 - Мобилна верзија на почетна страна на сајтот AUGmebel

\subsection{1 Пробајте ги производите во вашиот дом со аугментирана реалност}

На следниот екран од почетната страна се наоѓa дел (сивиот дел на слика 38) со кратки информации за Аугментираната реалност - информации како да се отвори производот во аугментирана реалност и што се е потребно за да се користи, а на крајот на текстот има 
копче „Повеќе информации“, кое редиректира кон страната „Аугментирана реалност“, на која има детални информации за користење на аугментираната реалност.

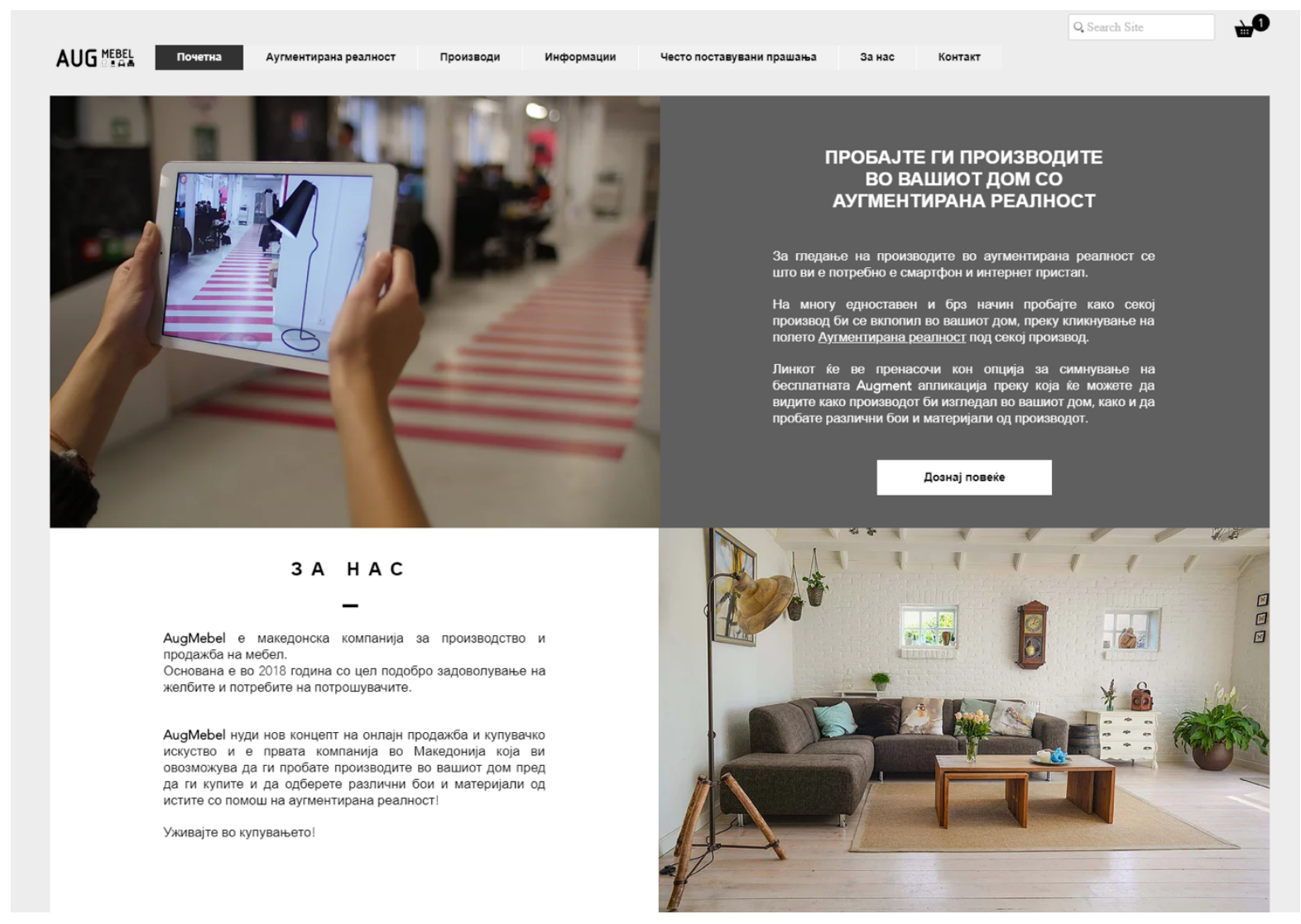

Слика 38 - Десктоп верзија на делот Аугментирана реалност од почетна страна на сајтот AUGmebel

\subsection{2 За нас}

Под полето со информации за Аугментирана реалност на почетната страна (белото поле на слика 38), се наоѓ делот „За нас“. Во овој дел се прикажани податоци за компанија AUGmebel, со цел посетителите да дознаат повеќе информации за компанијата, кога е основана, земја на потекло и нејзината мисија. Овој дел има за цел да ја зголеми веродостојноста и довербата на посетителите на сајтот, преку нудење на повеќе информации за фирмата која ги продава производите понудени на сајтот.

Категоријата „За нас“, од хоризонталната навигација ги има истите податоци, дополнети со дополнителни релевантни податоци. 

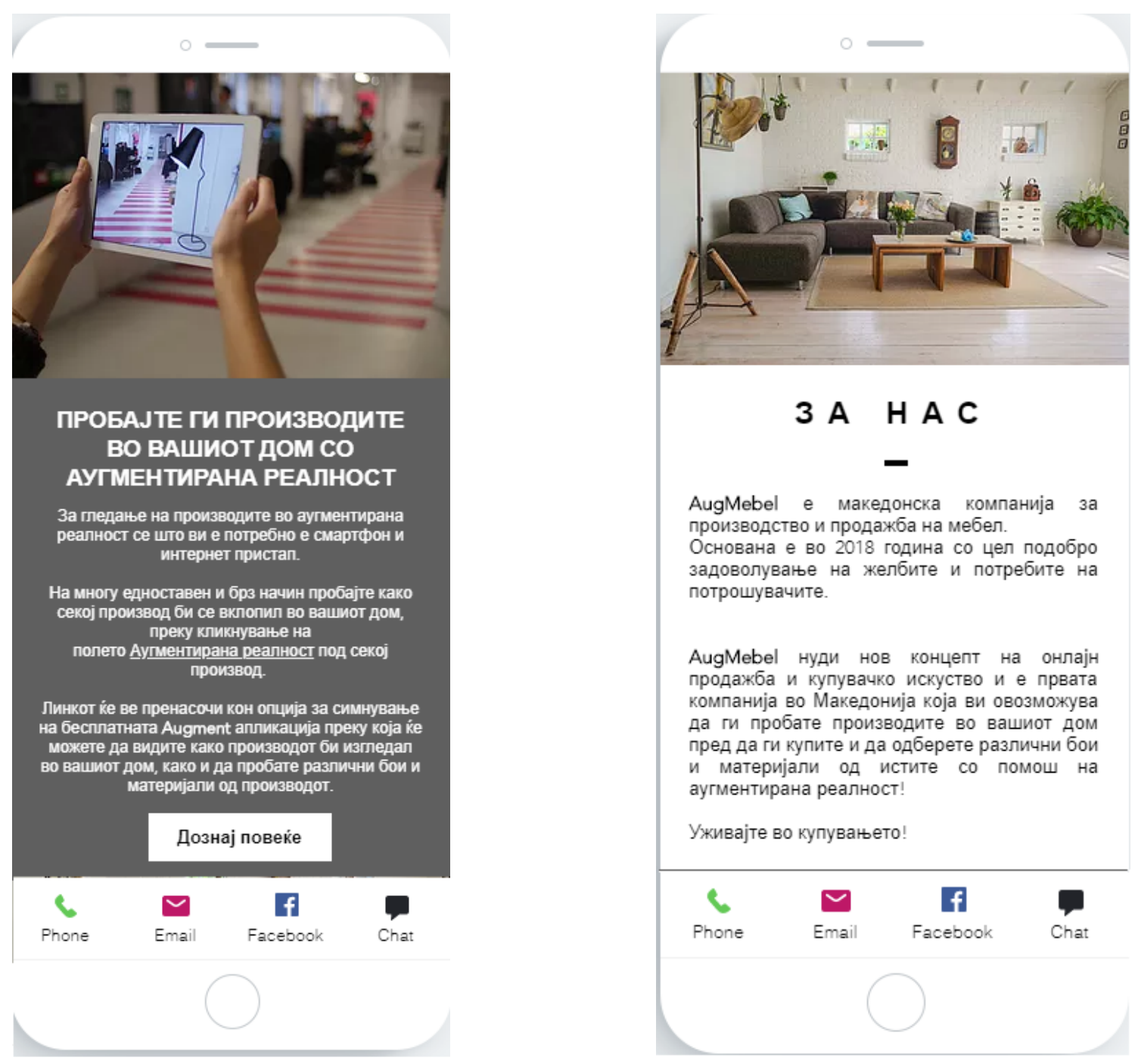

\section{A H A C}

AugMebel e македонска компанија за производство и продажба на мебел.

Основана е во 2018 година со цел подобро задоволување на желбите и потребите на потрошувачите.

AugMebel нуди нов концепт на онлајн продажба и купувачко искуство и е првата компанија во Македонија која ви овозможува да ги пробате производите во вашиот дом пред да ги купите и да одберете различни бои и материјали од истите со помош на аугментирана реалност!

Уживајте во купувањето!

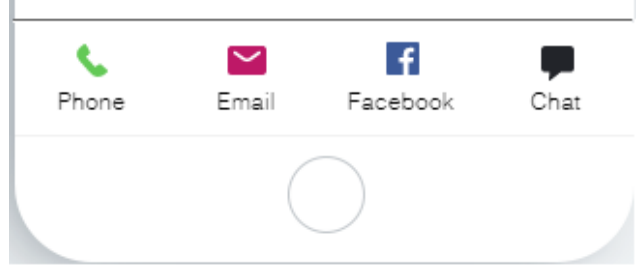

Слика 39 - Мобилна верзија на деловите „Аугментирана реалност “ и „За нас“ на почетната страна на cajтот AUGmebel

\subsection{3 Подножје на веб-сајтот (Footer)}

На слика 40 е прикажано подножјето на веб страната (на англиски - footer), кое се појавува најдолу на сите страни на сајтот. 


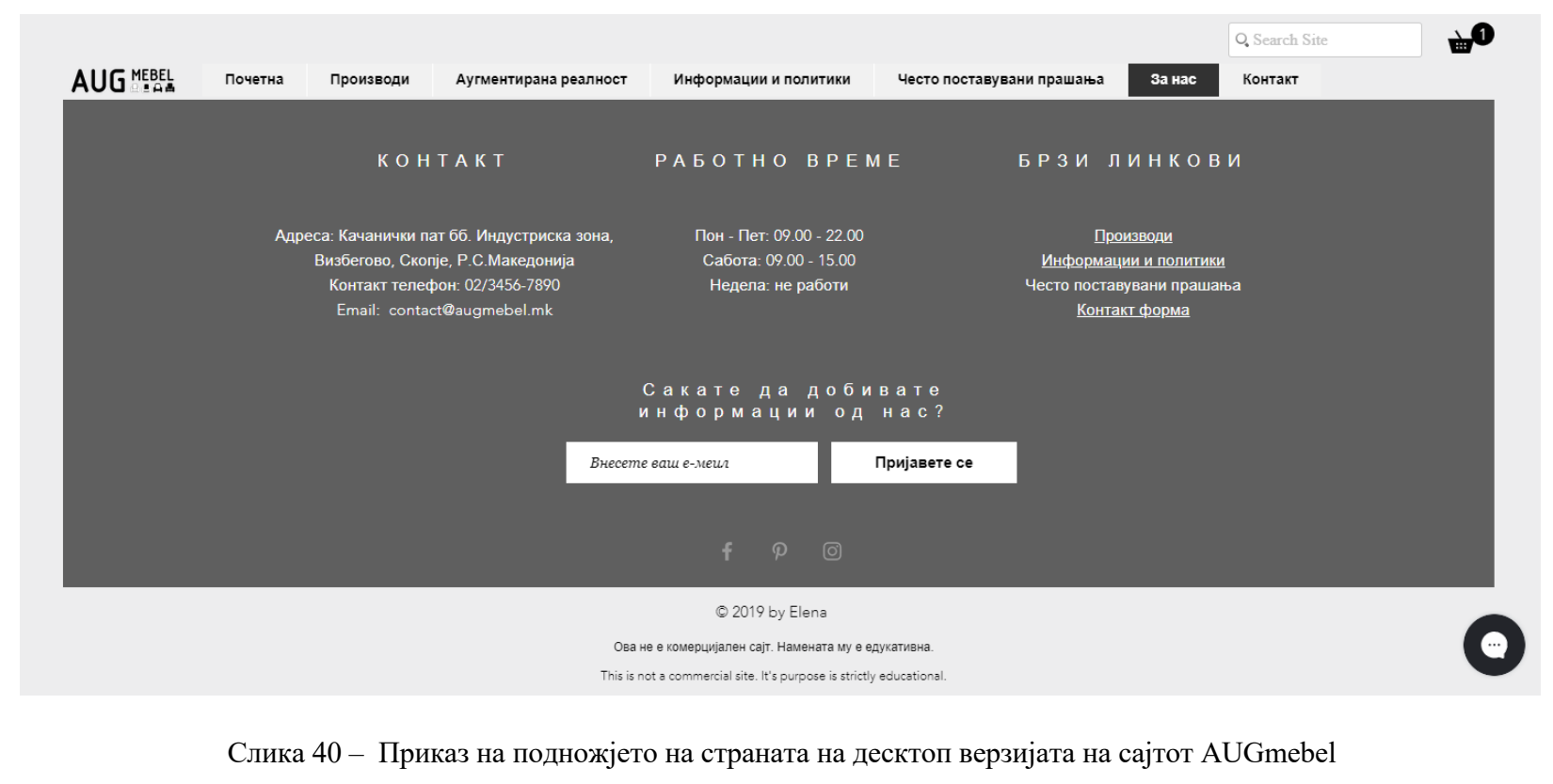

Подножјето на страната се состои од 6 дела:

\section{- Контакт}

Во овој дел се внесени контакт податоците на фирмата, како адреса, контакт телефон и контакт е-меил.

\section{- Работно време}

Овде е наведено работното време на фирмата.

\section{- Брзи линкови}

Овде се наоѓаат четири линкови кон најбитните делови од сајтот: Производи, Информации и политики, Често поставувани прашања и Контакт формата.

\section{- Билтен}

Во овој дел сите посетители кои сакаат редовно да добиваат информации од AUGmebel, можат да се пријават за добивање на билтен, преку оставање на нивна е-меил адреса.

\section{- Социјални медиуми}

Под билтенот се наоѓаат икони од социјални медиуми (Facebook, Instagram и Pinterest), кои се брзи линкови кон страните на социјалните медиуми на фирмата.

\section{- Кратки информации за сајтот}


На крајот на сајтот, во светло сивото поле се наоѓаат информации за тоа кој го изработил сајтот, во која година, како и информацијата „Ова не е комерцијален сајт. Намената му е едукативна“, преведена и на англиски јазик, во случај некој да го пронајде сајтот и да сака да купи производи онлајн, не сфаќајќки дека е изработен исклучиво за едукативна намена.

На сите страни на сајтот во долниот десен агол е присутна опција за директен контакт преку чет, со кој корисниците ќе можат да го контактираат трговецот и веднаш ќе добијат одговор. Оваа опција е прикажана на слика 41.

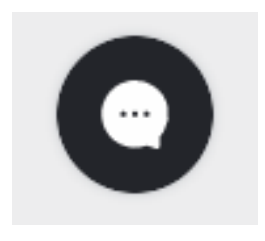

Слика 41 - Чет икона за директна комуникација со фирмата

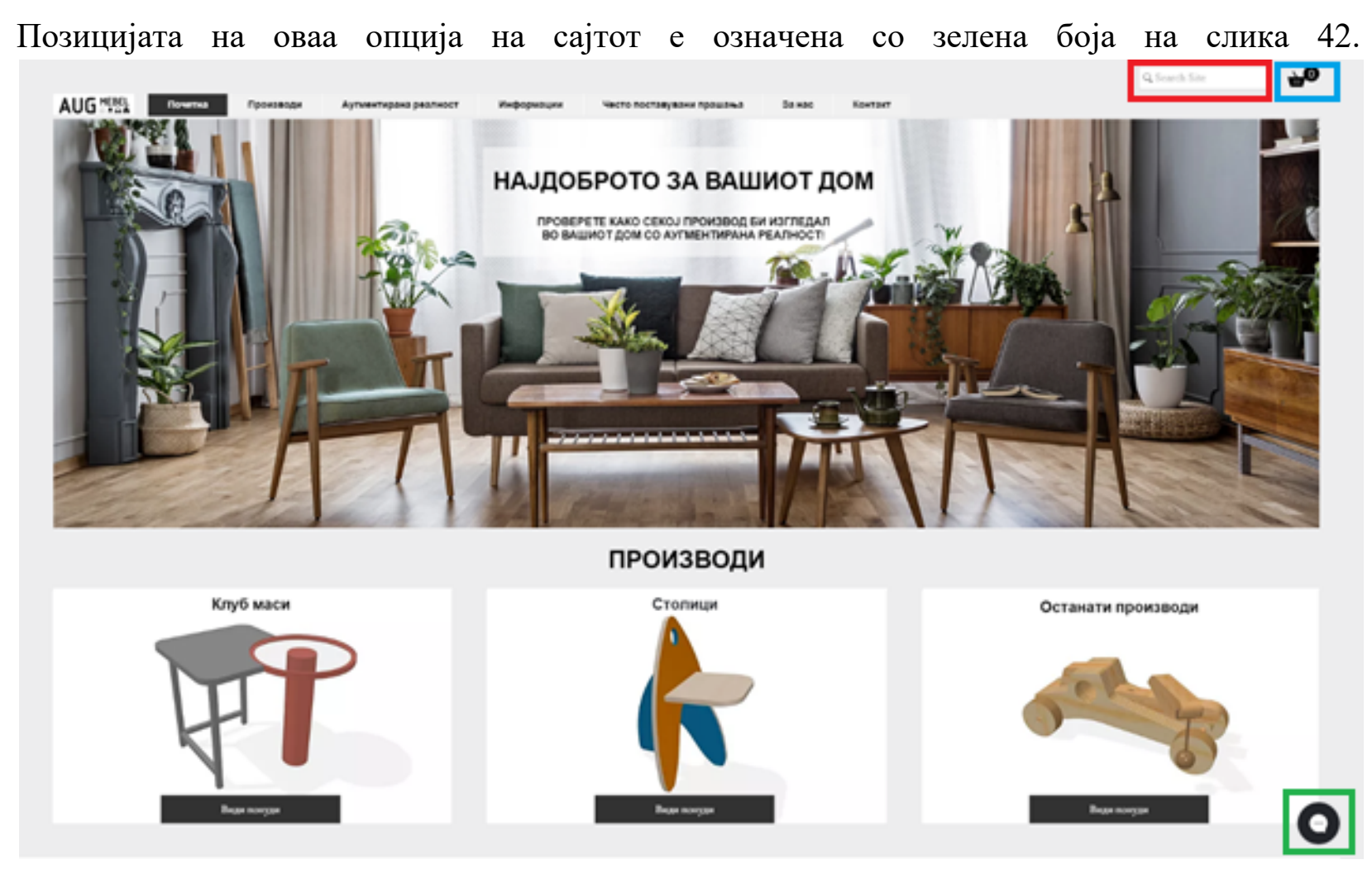

Слика 42 - Приказ на чет опцијата, search опцијата и кошничката за онлајн купување

Во горниот десен агол на сајтот се наоѓa полето „Search“ - кое е опција за брзо пребарување на сајтот. Оваа опција е означена со црвено на слика 42. 
Десно од Search полето, во горниот најдесен агол на сајтот се наоѓa „Кошничка за купување“ (означена со сино на слика 42). Кошничката е прикажана на сите страни на сајтот, а нејзината намена е посетителите да додаваат производи за онлајн купување во текот на посетата на сајтот, со кликање на копчето „Купи“ на саканиот производот. По додавање на производ во кошничката посетителот може директно да продолжи со плаќање на производот и оставање на информации за испорака или да ја затвори кошничката, па производот да остане во неа, со што на посетителот му се дава опцијата процесот на купување да го заврши подоцна.

Бидејќи се работи за едукативен сајт за намените на мојата магистерска работа, опциите за купување и плаќање на сајтот се оневозможени.

\section{2 Страна „Аугментирана реалност“}

На оваа страна може да се пристапи преку делот Аугментирана реалност во хоризонталната навигација на сајтот, како и преку делот Аугментирана реалност на почетната страна од сајтот. На оваа страна има детално упатство за користење на аугментирана реалност. Има детални инструкции прикажани со слики и текст, кои објаснуваат каде да се кликне за да се отвори производот во аугментирана реалност, како да се инсталира Augment апликацијата, како да се отворат производите во неа, како да се наместат на саканото место и агол во домот, и како да се промени боја / материјал на истите.

Десктоп верзијата и мобилната верзија на оваа страна се прикажани на слика 43 и 44 подолу. 


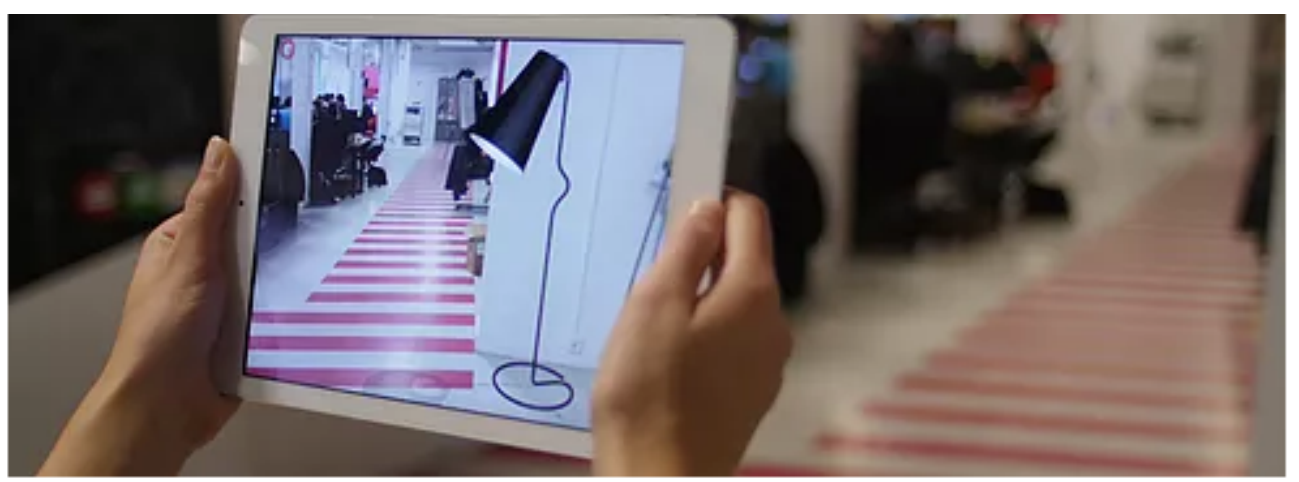

КОРИСТЕЊЕ НА АУГМЕНТИРАНАТА РЕАЛНОСТ

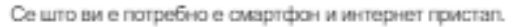

\section{Отворање на производот во аугментирана рөалност}

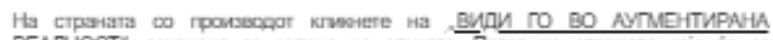

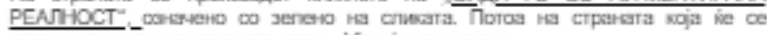

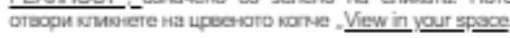

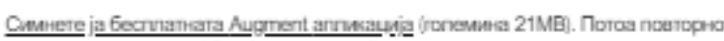

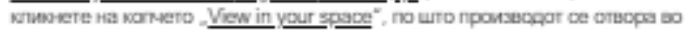
aугмestupana peanocr.

\section{Доколку произеодот го гледате од компјутер:}

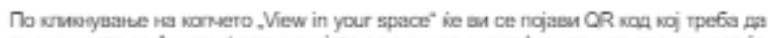

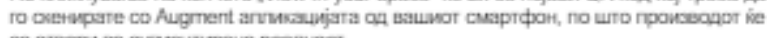
ce orвops so ayrmortupara pesanncet.

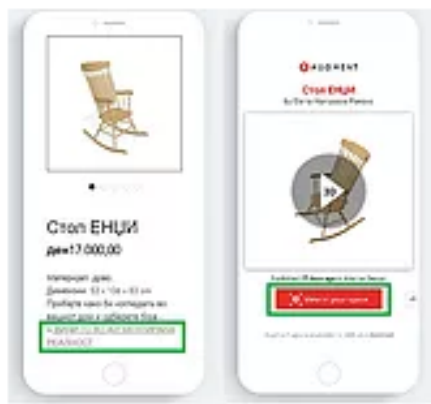

Поставувањө на производот на саканото мөсто: со виечеье на производрт со еден прст на екранот.

Ротирање на производот на саканото мөсто: со влеvене на происводот со диа прста кон саканиот aran.

Мөнувањө на боја или материјал ка производот:

Konvere ha wodara so dankor res aron qu eipasar foosuera co xeneno ra crisarai.

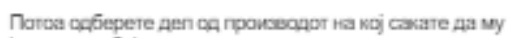
ja смените 6ojara

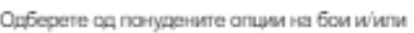

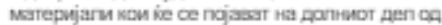
expanot.

Иcrara noctarka nceropere ja и за дpyruor дas нe прамавсерт.
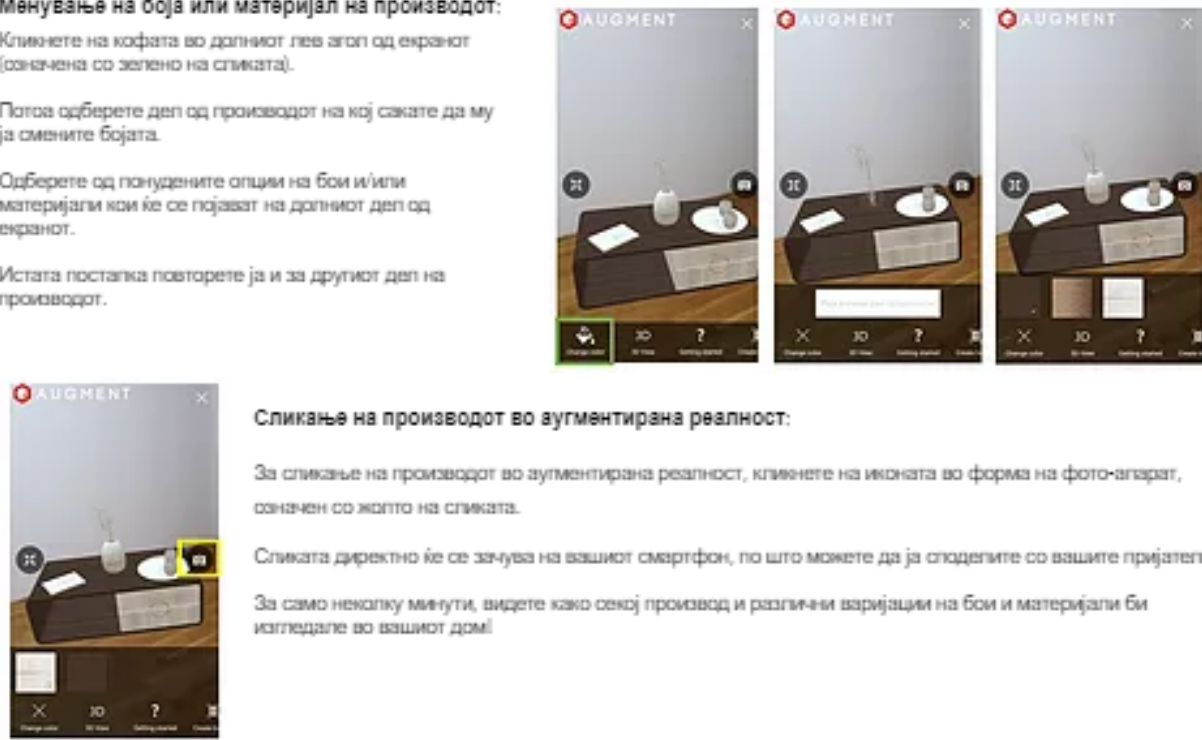

Сликане на производот во аугментирана реалност:

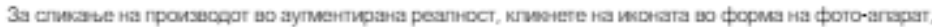
сонауен co жorro нa crukara.

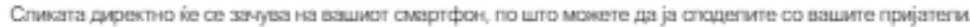

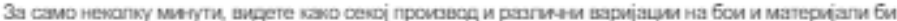

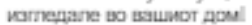

\section{Одбери производ}

Слика 43 - Десктоп верзија на страната „Аугментирана реалност“на сајтот AUGmebel 


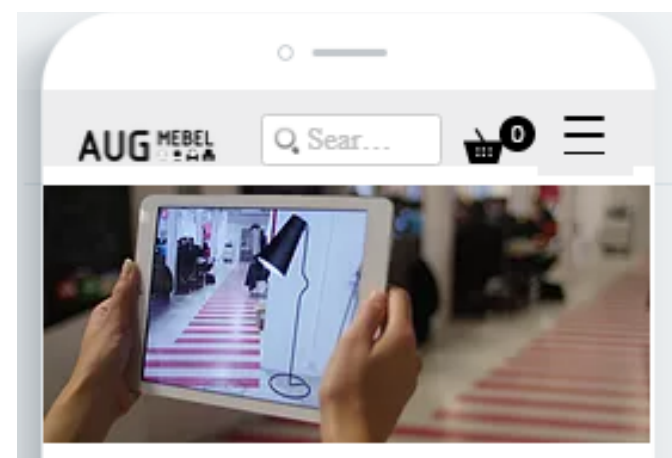

КОР ИСТЕ ЮЕ H А

A УГ МЕ Т И РА А А A PЕAЛ Н O С T

Се што ви е потребно е смартфон и интернет пристап.

Отворање на производот во аугментирана реалност:

На страната со производот кликнете на ВИДИ ГО ВО АУГМЕНТИРАНА РЕАЛНОСТ "означено со зелено на сликата. Потоа на страната која ќе се отвори кликнете на црвеното копче .View in your space.
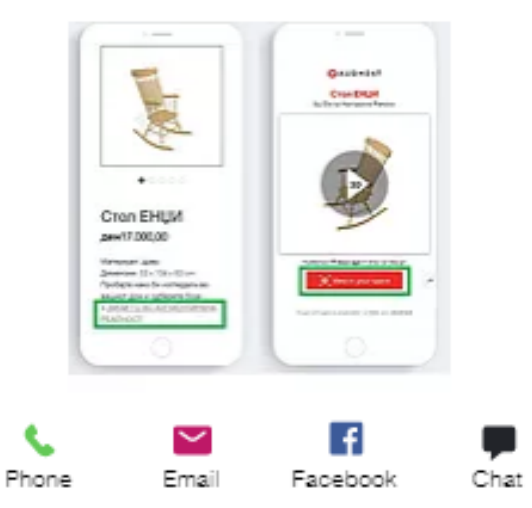

Слика 44 - Мобилна верзија на страната „Аугментирана реалност“ на сајтот AUGmebel 


\section{3 Страна „Информации“}

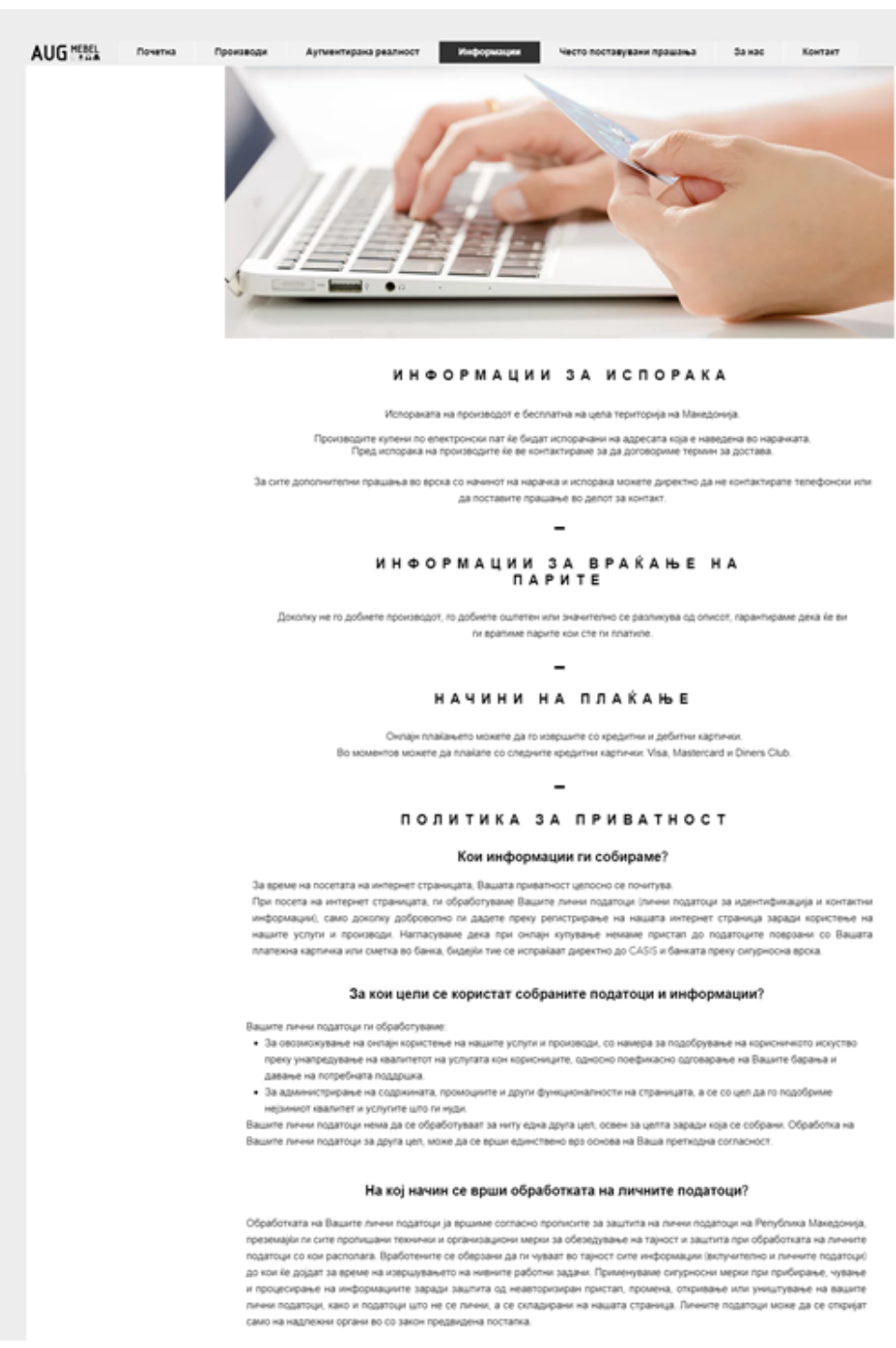

Слика 45 - Десктоп верзија на страната „Информации“ на сајтот AUGmebel

На слика 45 е прикажана страната „Информации“ која вклучува битни информации за потрошувачите како - „Информации за испорака“; „Информаци за враќње на парите“, „Начини на плаќање“ и „Политика за приватност“.

За сите останати информации, посетителите можат да ја контактираат фирмата преку чет опцијата која е постојано достапна во долниот десен агол на сајтот, како и преку достапните контакт форма и контакт информации на сајтот. 
Во делот „Информации за испорака“ посетителите ќе ги најдат сите потребни информации за испораката на производите. Во делот „Информаци за враќање на парите“, ќе добијат гаранција дека доколку не го добијат производот, го добијат оштетен или значително се разликува од описот, ќе им бидат вратени парите кои ги платиле.

Во делот „Начини на плаќање“ има информација за достапните начини за онлајн плаќање.

Во делот „Политиката за приватност“ посетителите можат да прочитаат на кој начин се чуваат нивните податоци на сајтот, дека тие се целосно безбедни и не се користат за друга намена, освен за онаа за која се собрани. Оваа политика служи за да ја намали несигурноста на потрошувачите при онлајн купување, поради стравот од злоупотреба на нивните податоци, како и за поголема транспарентност на сајтот.

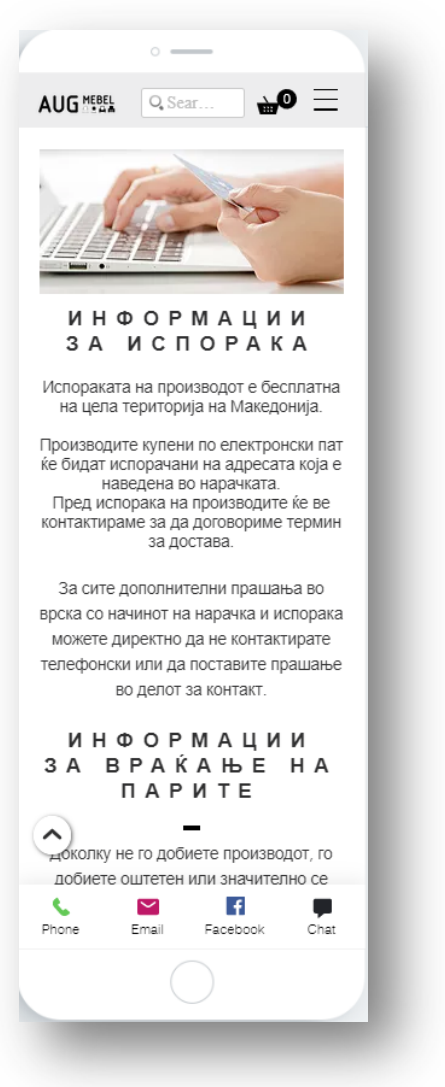

Слика 46 - Мобилна верзија на страната „Информации“ на сајтот AUGmebel 


\section{4 Страна „Често поставувани прашања“}

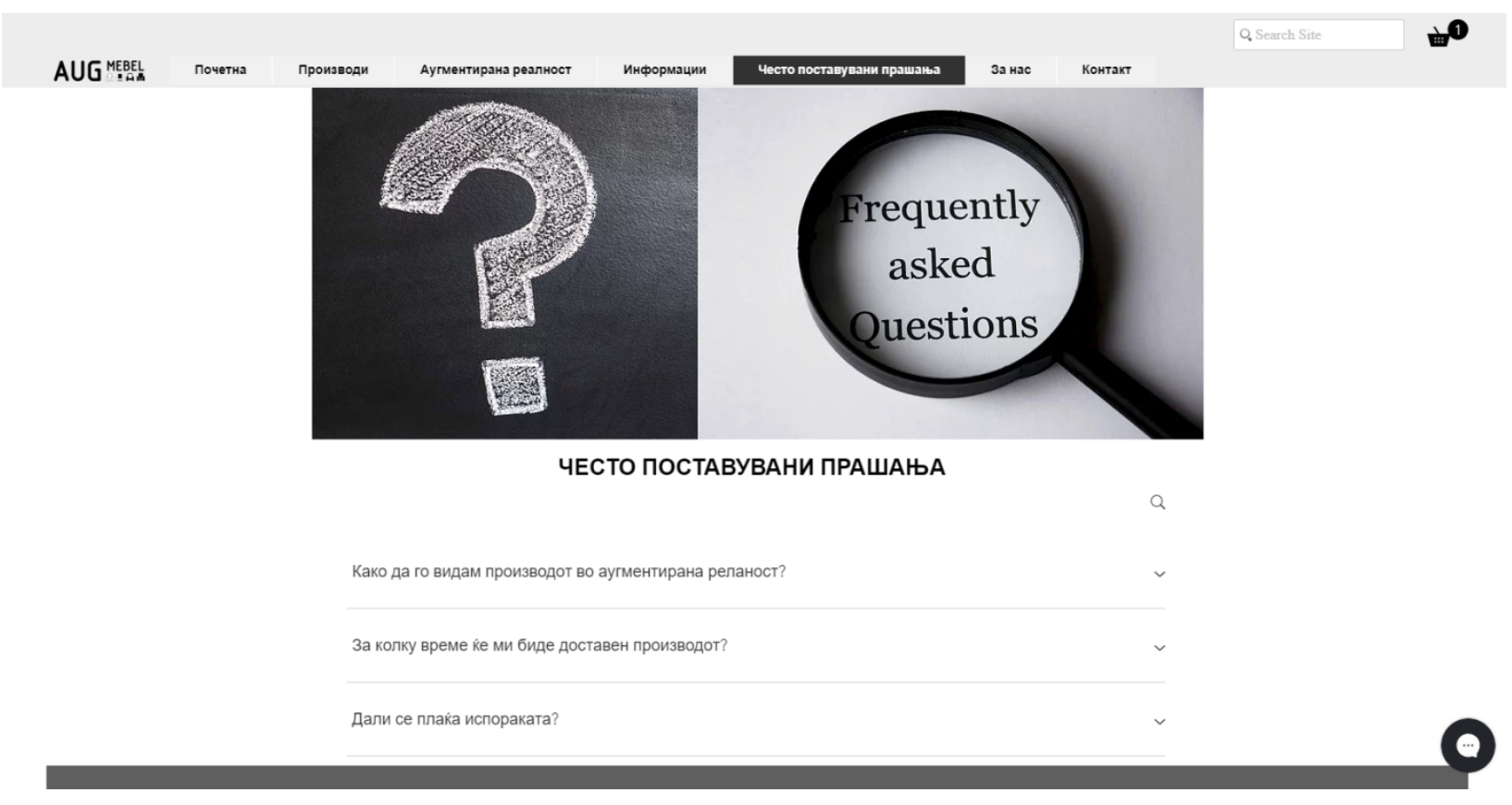

Слика 47 - Десктоп верзија на страната „Често поставувани прашања“ на сајтот AUGmebel

На слика 47 е прикажана страната со „Често поставувани прашања“, на која посетителите лесно можат да најдат одговор на најчесто поставуваните прашања кои вклучуваат прашања во врска со користењето на аугментираната реалност и прашањата во врска со испораката. Овој дел постојано би се дополнувал со одговори на најчесто поставуваните прашања која компанијата ги добива од нејзините клиенти.

\section{5 Страна „Контакт“}

На Контакт страната (слика 48) е прикажана контакт форма за директно испраќае на емеил кон компанијата, на кој посетителите ќе добијат одговор преку е-меил.

Овде се достапни и контакт телефон и е-меил адреса на фирмата, за оние кои преферираат поинакви начини на комуникација.

Формата за директни пораки (чет) е цело време достапна во долниот десен агол на сајтот, а контакт информациите се достапни и во подножјето на страната. 


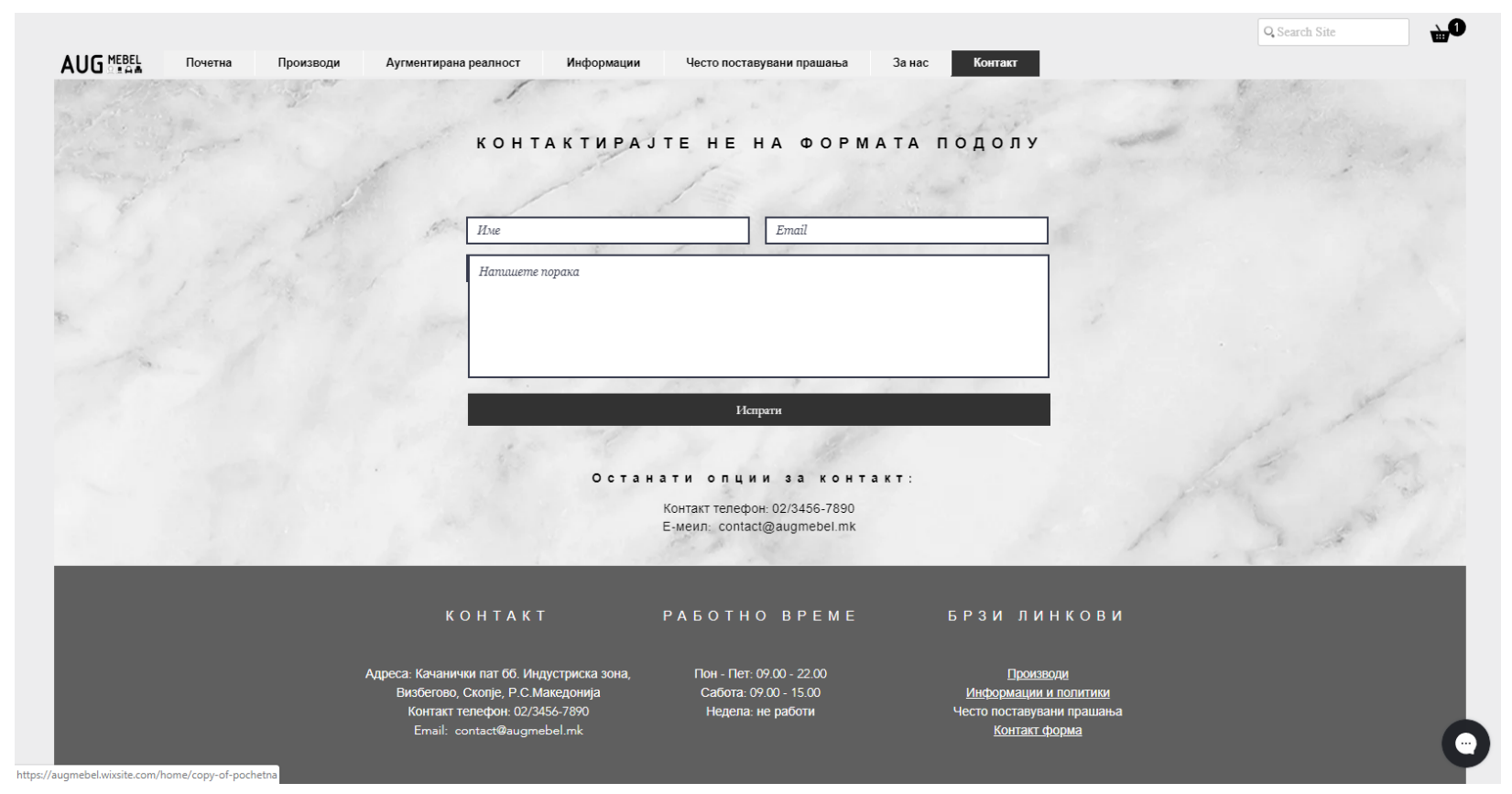

Слика 48 - Десктоп верзија на „Контакт“ страната на сајтот AUGmebel

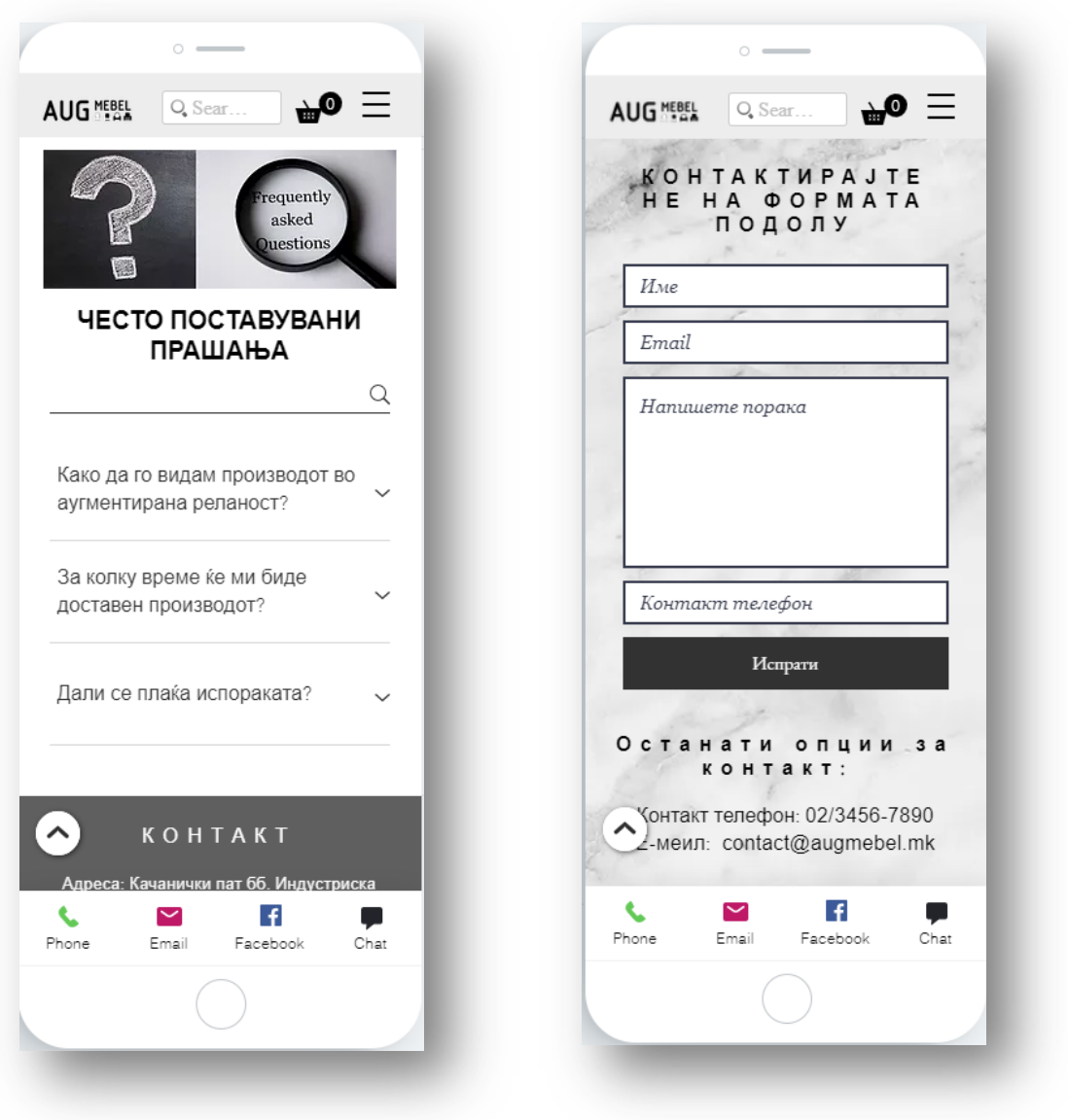

Слика 49 - Мобилна верзија на страните „Често поставувани прашања“ и „Контакт“ на сајтот AUGmebel 


\section{6 Страна „За нас“}

Страната „За нас“ е прикажана на слика 50. На оваа страна се наоѓаат подетални информации за компанијата, контакт информации и работно време.

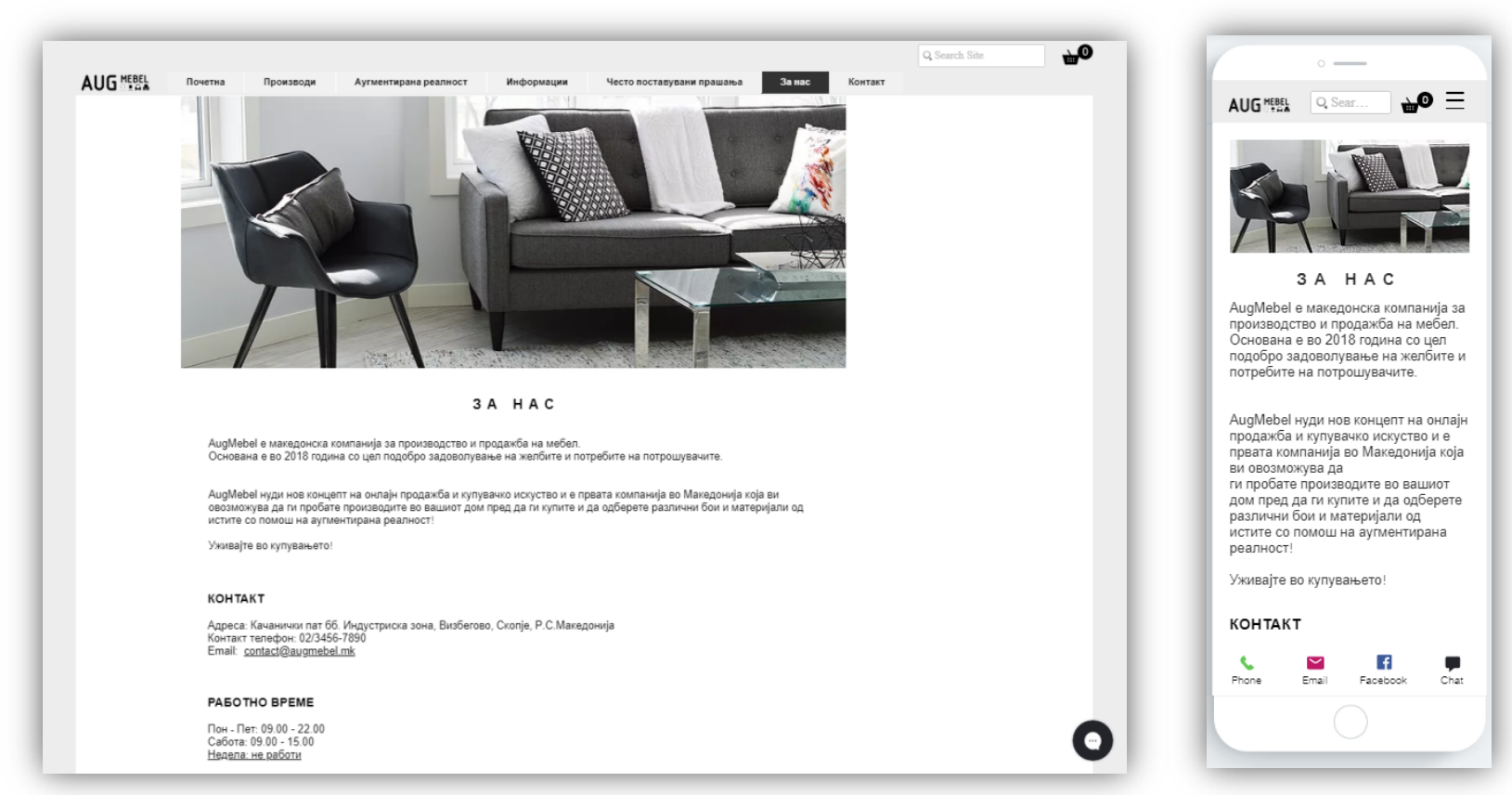

Слика 50 - Десктоп и мобилна верзија на страната,За нас“ на сајтот AUGmebel

\section{7 Страна „Производи“}

На слика 51 е прикажана страната со сите производи од сите категории во асортиманот на AUGmebel. Под секој производ стои името на производот и цената.

На одредени производи има дополнителна ознака во горниот десен агол на банерот од секој производ - правоаголна икона во црна боја, со бел текст, во која е нагласена некаква акција или информација за производот, како „НОВО“ - за нов производ, „15\% ПОПУСТ“ - за попуст на одреден производ и слично.

Од левата страна има опција за филтрирање на производите по цена и категорија. 


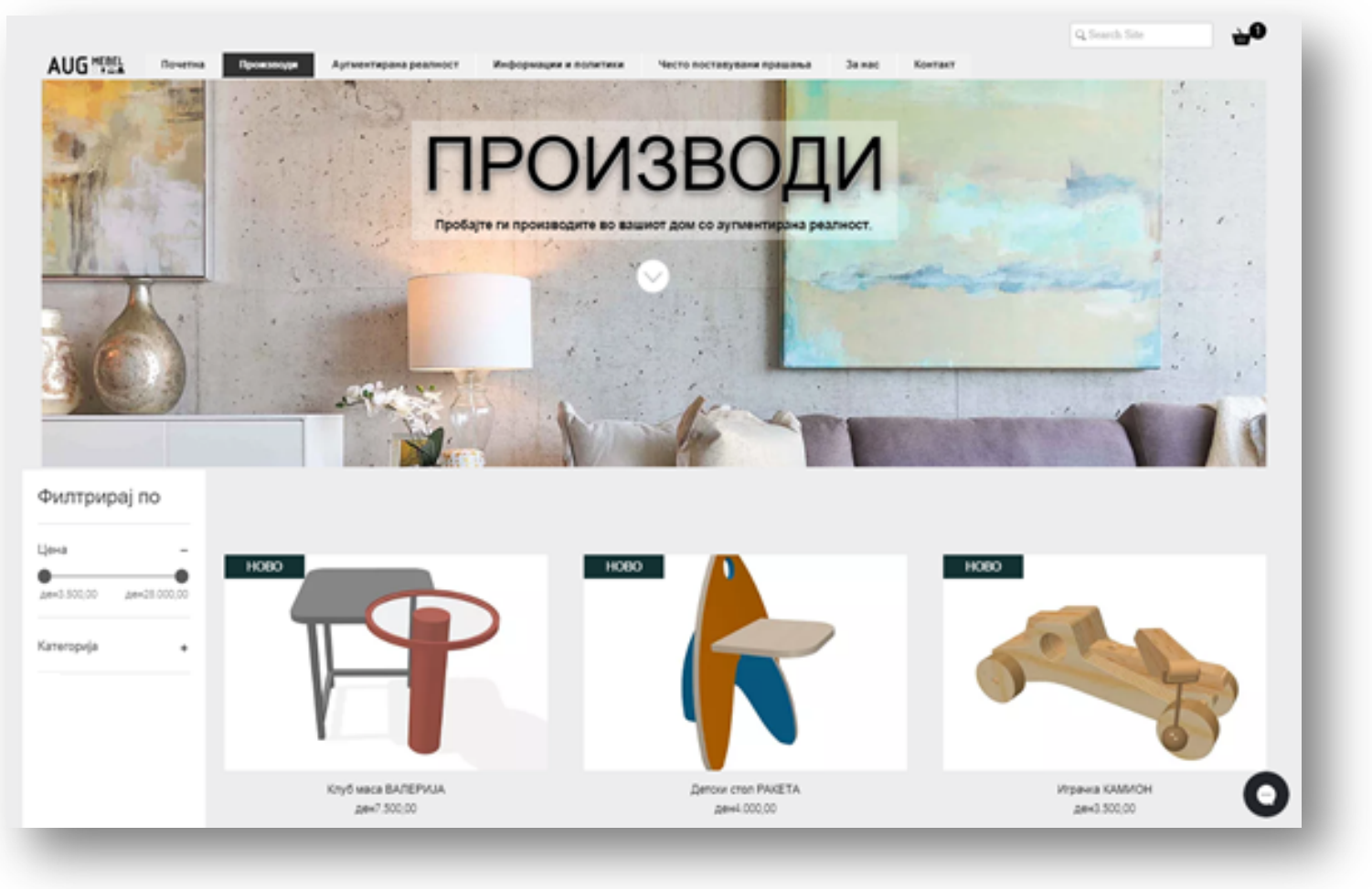

Слика 51 - Десктоп верзија на страната „Производи“ на сајтот AUGmebel
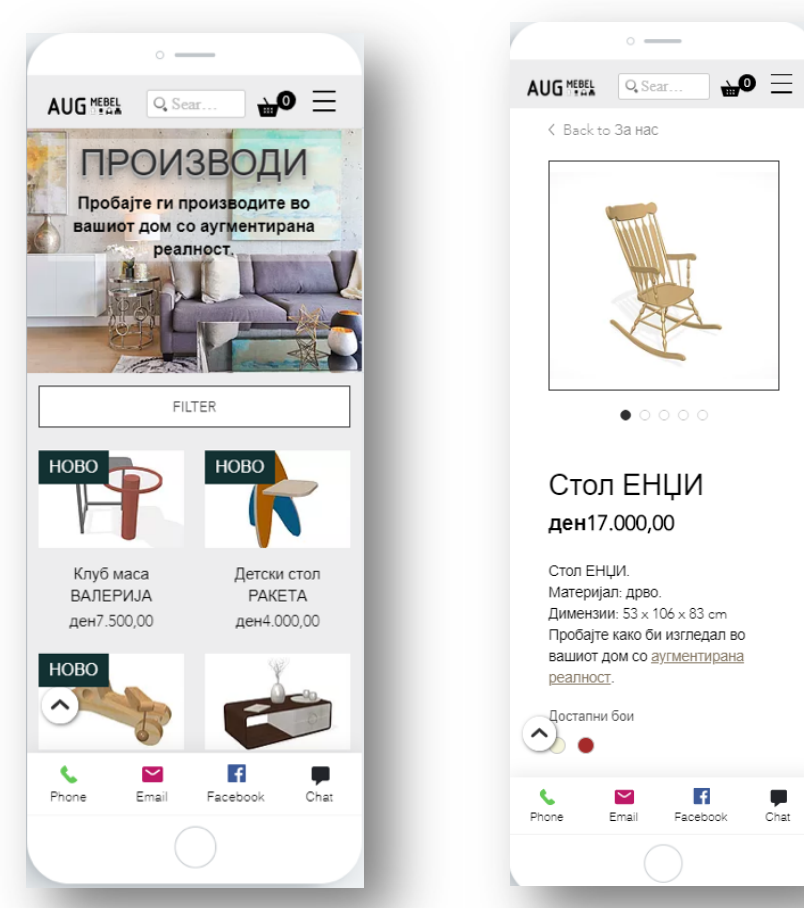

Стол ЕНџИ

ден17.000,00

Стол Енџи.

Материјал: дрво

Димензии: $53 \times 106 \times 83 \mathrm{~cm}$

Пробајте како би изгледал во

вашиот дом со аугментирана

реалност.

(

$\underset{\text { Phore }}{\operatorname{en}} \underset{\text { Facebook }}{\text { If }}$

Слика 52 - Мобилна верзија на страните „Производи“ и страната со конкретен производ на сајтот AUGmebel 


\section{8 Страна со конкретен производ}

На слика 53 е прикажан изгледот на страната за приказ и продажба на конкретен производ. На оваа страна ударно е поставена слика од производот, а десно од неа се наоѓаат останатите слики од производот, каде производот може да се види од други агли и во други бои / материјали. Десно од сликите се наоѓа името на производот, а под него е цената, краток опис на производот (материјал, димензии), линк за гледање на производот во аугментирана реалност, информација за достапни бои и опција за купување на производот. Со бирање на саканата количина од производот и кликнување на копчето „Купи“, производот се додава во кошничката за купување.

Под количината се наоѓаат опции за споделување на производот на социјалните медиуми.

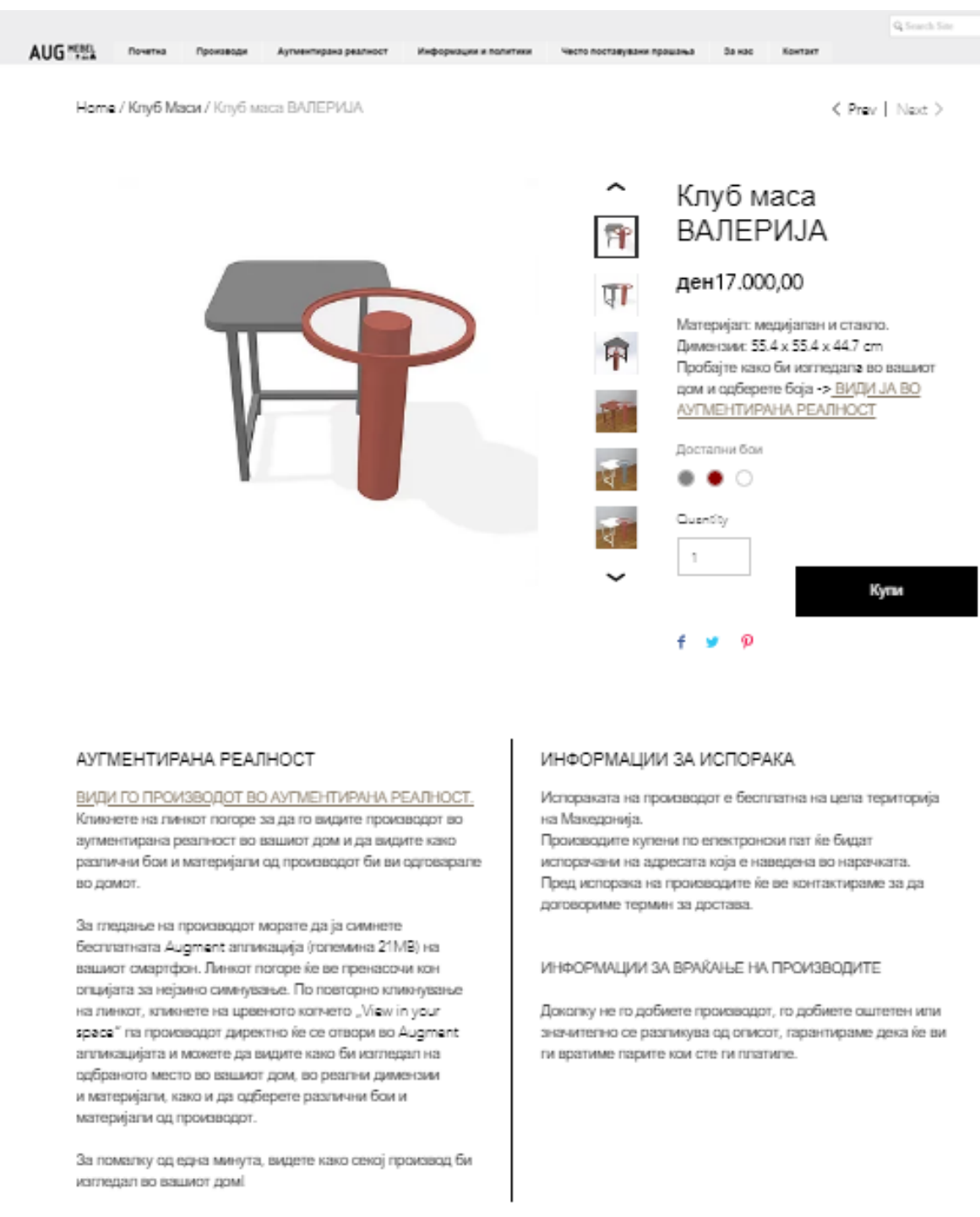

Слика 53 - Десктоп верзија на страна со конкретен производ на сајтот AUGmebel 
На страната со конкретен производ, на две места е достапна опцијата за гледање на производот во аугментирана реалност. За поголема видливост на оваа опција, таа е достапна во краткиот опис на производот, како и во полето Аугментирана реалност.

Под сликата од производот се наоѓаат две полиња, со следните информации:

1. Поле „Аугментирана реалност“

2. Поле „Информации за испорака“ и „Информации за враќање на производите“.

\subsection{1 Поле „Информации за испорака и враќање на производите“ на страната со конкретен производ}

Ова поле се наоѓa во долниот десен агол на сајтот. Во ова поле се наоѓаат накратко сумирани информациите околу испораката и враќњето на производите, кои се подетално објаснети во делот „Информации“ на сајтот. Во овој дел има битни информации околу испораката на производите, како тоа дека испораката е бесплатна на цела територија на Р.С. Македонија и дека се договара термин за испорака со купувачите.

Во овој дел се наоѓаат и информации за враќае на производите - доколку купувачите не го добијат производот, го добијат оштетен или значително се разликува од описот, имаат гаранција дека ќе им се вратат парите кои ги платиле.

Овие информации служат да ја намалат несигурноста од онлајн купување и да помогнат во процесот при донесување одлука за онлајн купување.

\subsection{2 Поле „Аугментирана реалност“ на страната со конкретен производ}

Ова поле се наоѓа во долниот лев агол на страната, веднаш под сликата на производот. Првата реченица во ова поле е „ВИДИ ГО ПРОИЗВОДОТ ВО АУГМЕНТИРАНА PЕАЛНОСТ“ и е hyperlink кој води кон опцијата за гледање на производот во аугментирана реалност. Под оваа реченица има кратко објаснување на начинот на кој посетителите можат да го видат производот во аугментирана реалност. Овој процес подетално е објаснет во делот „Аугментирана реалност“ на почетната страна на сајтот, а детално упатство има на дедицираната страна „Аугментирана реалност“.

Подолу ќе го прикажам процесот на отворање на производот во аугментирана реалност, негово поставување на саканото место во домот, конфигурирање на различни материјали и бои и правење на слики од производот на саканото место во домот. 


\section{8. Пренос и прикажување на CAD модели на производи во аугментирана реалност со конфигурирање на различни бои и материјали}

За гледање на производите во аугментирана реалност се што е потребно е смартфон и интернет пристап.

\section{1 Отворање на производот во аугментирана реалност}

За да се види производот во аугментирана реалност, на страната со конкретен производ на сајтот AUGmebel треба да се кликне на линкот „Види го во аугментирана реалност“ во краткиот опис на производот или на линкот „Види го производот во аугментирана реалност“, кој се наоѓа во полето „Аугментирана реалност“, под сликата од производот.

Линкот ќе отвори прозор со ЗД приказ на производот, под кој се наоѓа црвено копче „View in your space“. По кликнување на ова копче посетителите ќе бидат пренасочени кон бесплатната Augment апликација на Playstore/App store, од каде треба да ја симнат (големина 21MB).

По симнување на Augment апликацијата, треба повторно да се кликне на црвеното копче „View in your space“, по што производот се отвора во Augment апликацијата. Откако еднаш апликацијата ќе биде инсталирана, по кликнување на копчето „View in your space“ посетителите ќе бидат директно пренасочени кон приказот на саканиот производ во аугментирана реалност во Augment апликацијата, во нивната реална околина.

Доколку производот се гледа од компјутер, по кликнување на копчето „View in your space“ се појавува QR код кој треба да се скенира co Augment апликацијата од смартфон, по што производот ќе се отвори во аугментирана реалност (доколку апликацијата не е инсталирана, прво ќе треба да се инсталира на смартфонот на корисникот). 


\section{2 Поставување на производот на саканото место во домот}

На првото отворање на производ во Augment апликацијата следува кратка обука во неколку секунди која објаснува како да се намести производот на саканото место во домот (се поместува на саканото место преку влечење на производот со еден прст на екранот кон саканото место) и како да се ротира производот за да се подеси во саканиот агол (производот се поместува со два прста во саканиот агол).

Смартфонот автоматски го препознава просторот на корисникот и производот се прикажува на подот.

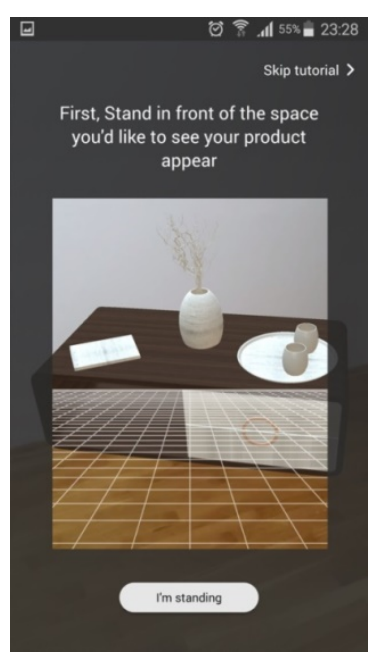

Слика 54 - Кратка обука за поставување и конфигурирање на производите во аугментирана реалност во Augment апликацијата.

\section{3 Промена на боја или материјал на производот}

За промена на боја или материјал на производот, треба да се кликне на кофата во долниот лев агол од екранот (означена со зелено на слика 55), по што треба да се одбере дел од производот на кој треба да му се смени бојата / материјалот (ако производот има опција за комбинирање на неколку различни бои и материјали, доколку нема веднаш ги дава достапните материјали и бои), потоа се одбира од понудените опции на бои и материјали кои ќe се појават на долниот дел од екранот. Со кликање на одредена боја / материјал, директно се менува бојата / материјалот на производот кој се гледа во аугментирана реалност.

Истиот процес се повторува и за другите делови на производот на кои треба да им се промени материјалот или бојата. Овој процес е прикажан на слика 55.
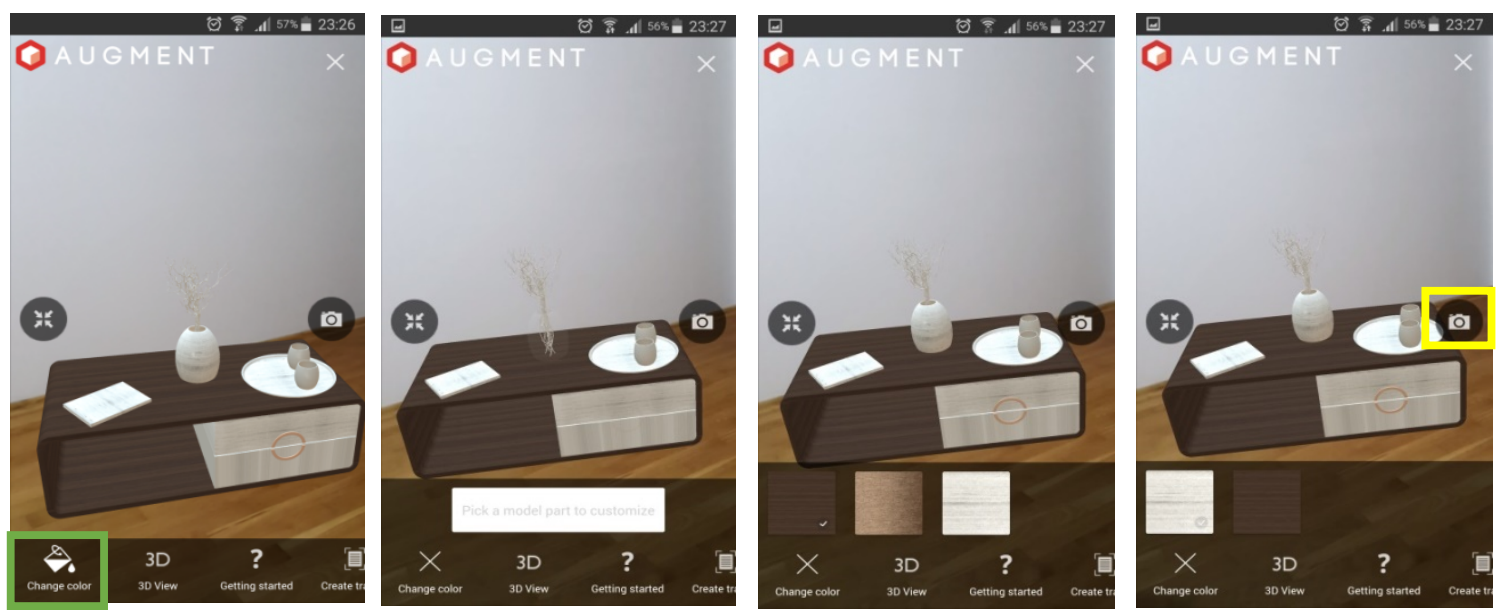

Слика 55 - Приказ на опцијата за промена на материјал / боја на различни делови на производ во Augment aпликацијата. 


\section{4 Сликање на производот во аугментирана реалност}

За сликање на производот во аугментирана реалност, треба да се кликне на иконата во форма на фото-апарат, која се наоѓa на десната страна на екранот, означена со жолто на слика 55.

По кликнување на оваа икона, сликата директно ќе се зачува на смартфонот на корисникот, по што може да се сподели со пријателите.

Процесот за гледање на производите во аугментирана реалност е многу едноставен и брз. За само неколку минути, корисниците можат да видат како секој производ и различни конфигурации на бои и материјали на производот би изгледале во нивниот дом, да ги споделат со нивните пријатели и да добијат мислење пред купувањето. Аугментираната реалност ќе го забрза процесот на донесување на одлука за купување и ќе ги зголеми онлајн продажбите, а од друга страна ќе влијае на намалување на бројот на вратени производи, што ќе донесе дополнителни заштеди за фирмата.

Подолу се наоѓаат слики од производите од AUGmebel сајтот, сликани во аугментирана реалност, со различни опции на бои и материјали. 

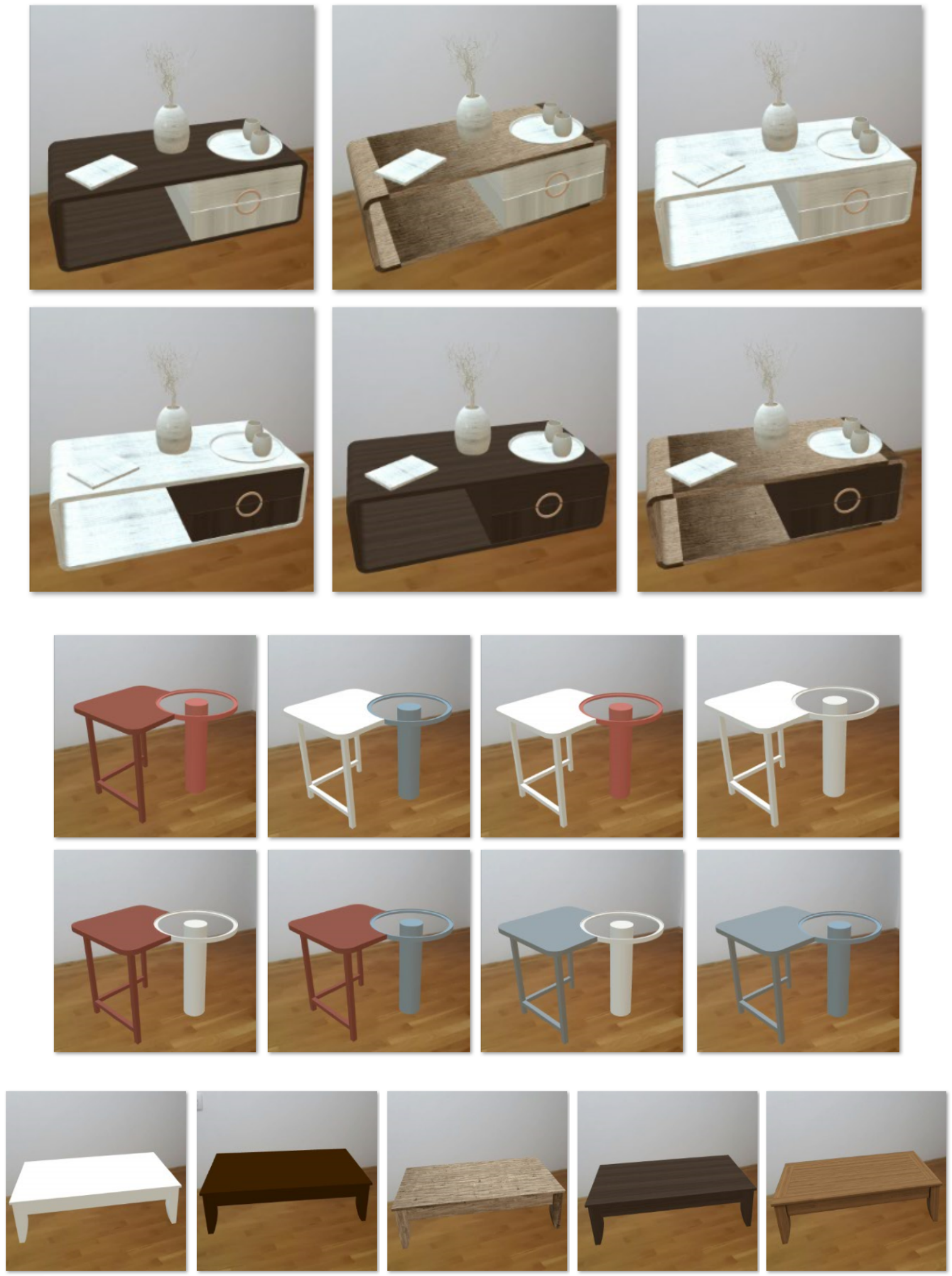

Слика 56 - Приказ на на различните достапни бои и материјали на производите во категоријата „Клуб маси“ на сајтот AUGmebel во аугментирана реалност 

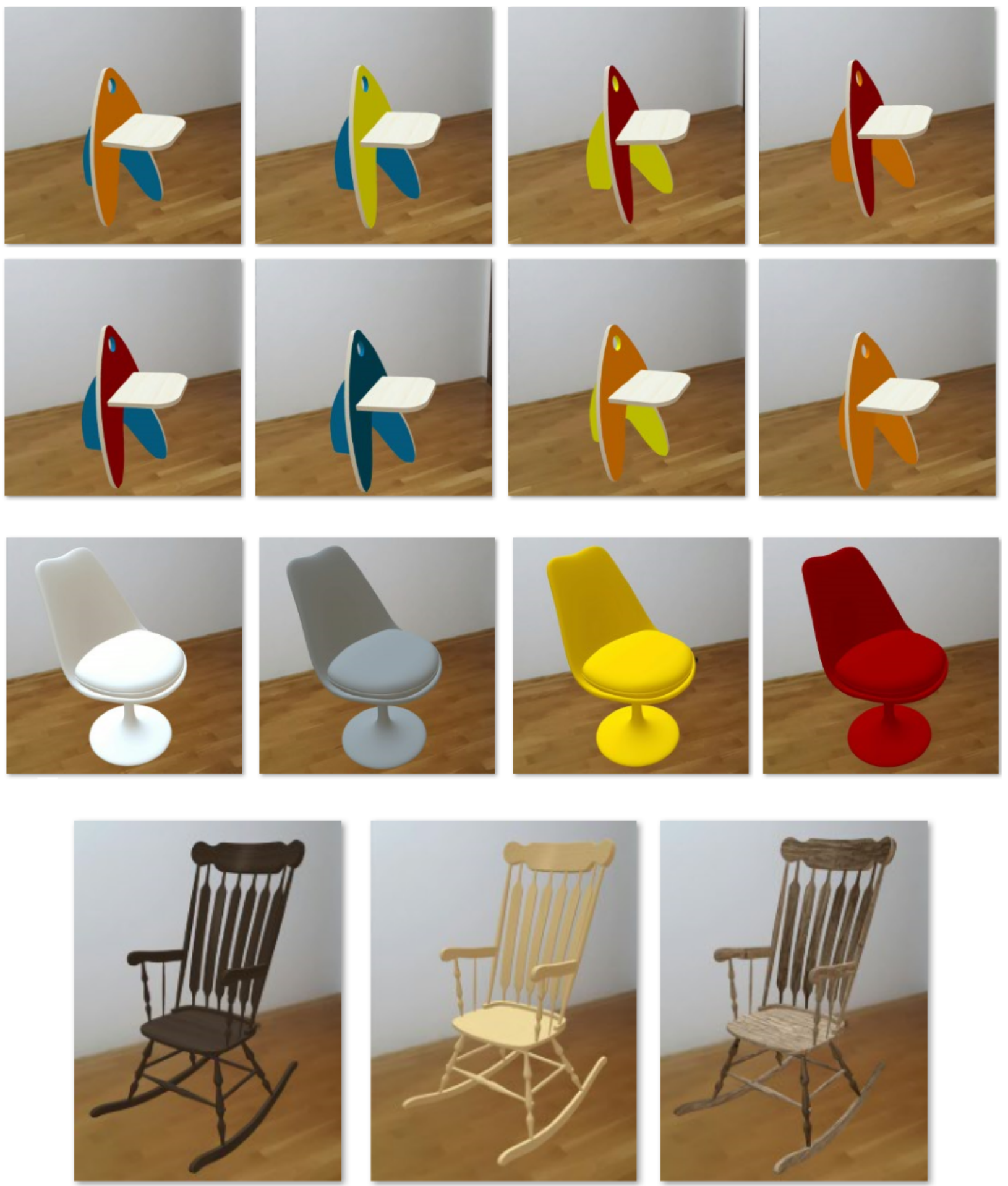

Слика 57 - Приказ на различните достапни бои и материјали на производите во категоријата „Столици“ на сајтот AUGmebel во аугментирана реалност 

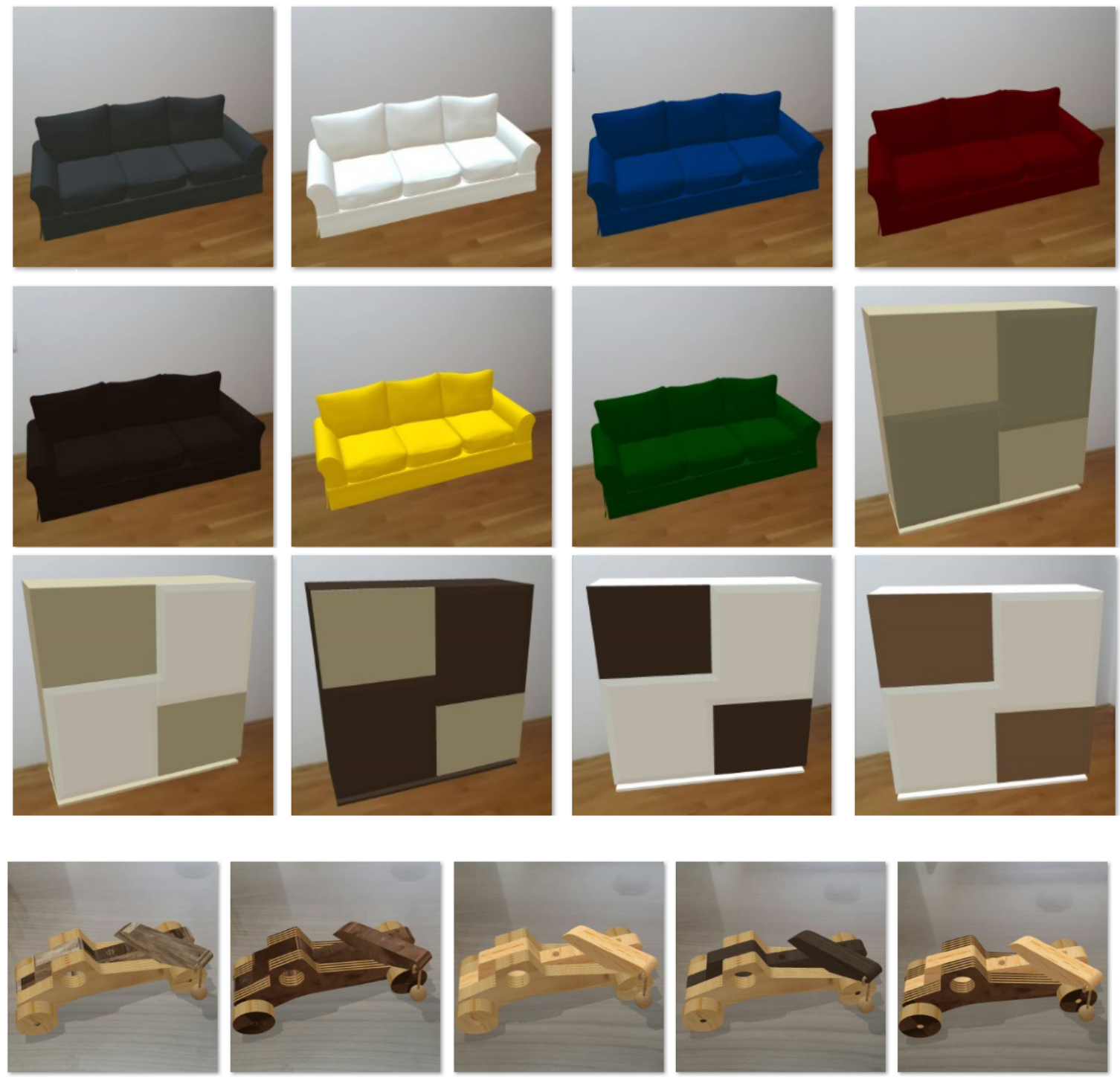

Слика 58 - Приказ на на различните достапни бои и материјали на производите во категоријата „Останати производи“ на сајтот AUGmebel во аугментирана реалност 

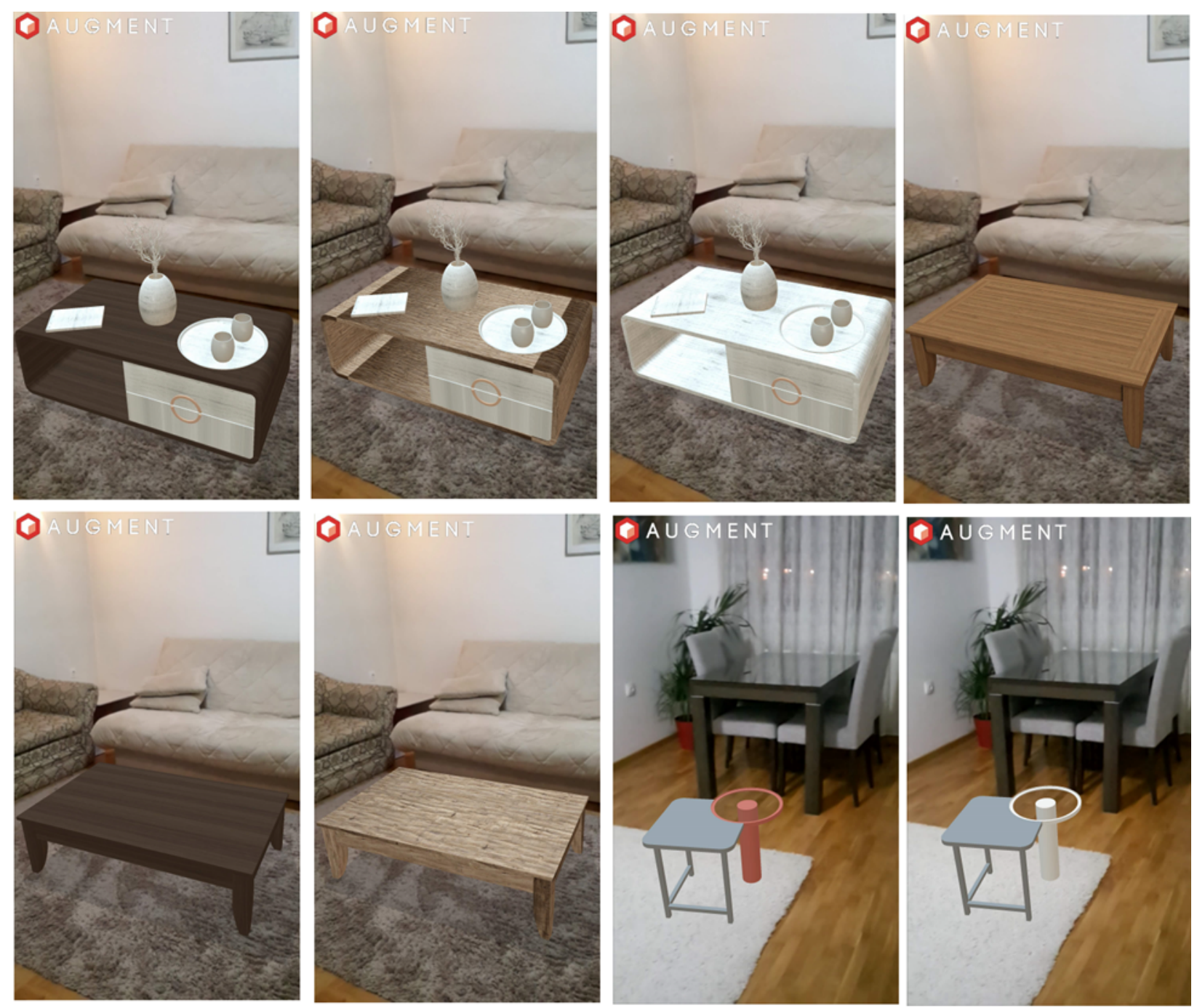

Слика 59 - Приказ на производите во категоријата „Клуб маси“ на сајтот AUGmebel во аугментирана реалност 


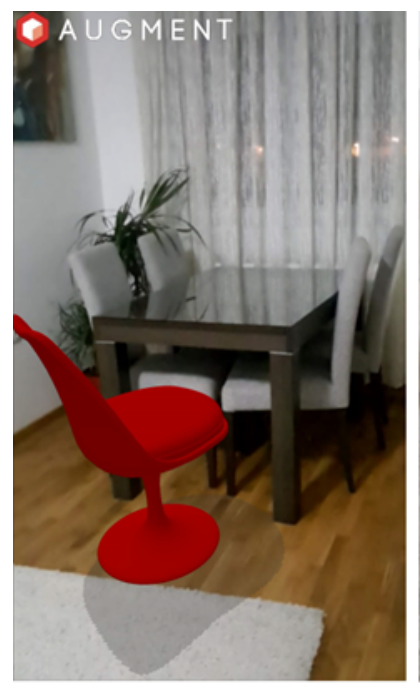

○

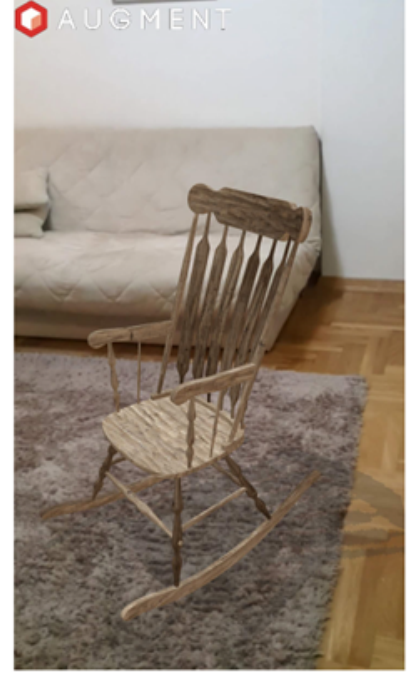

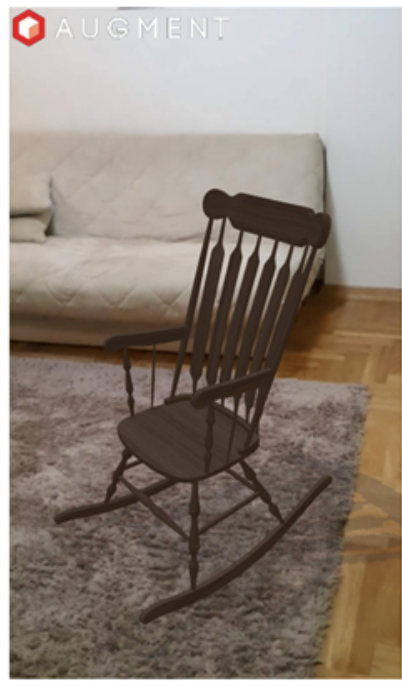
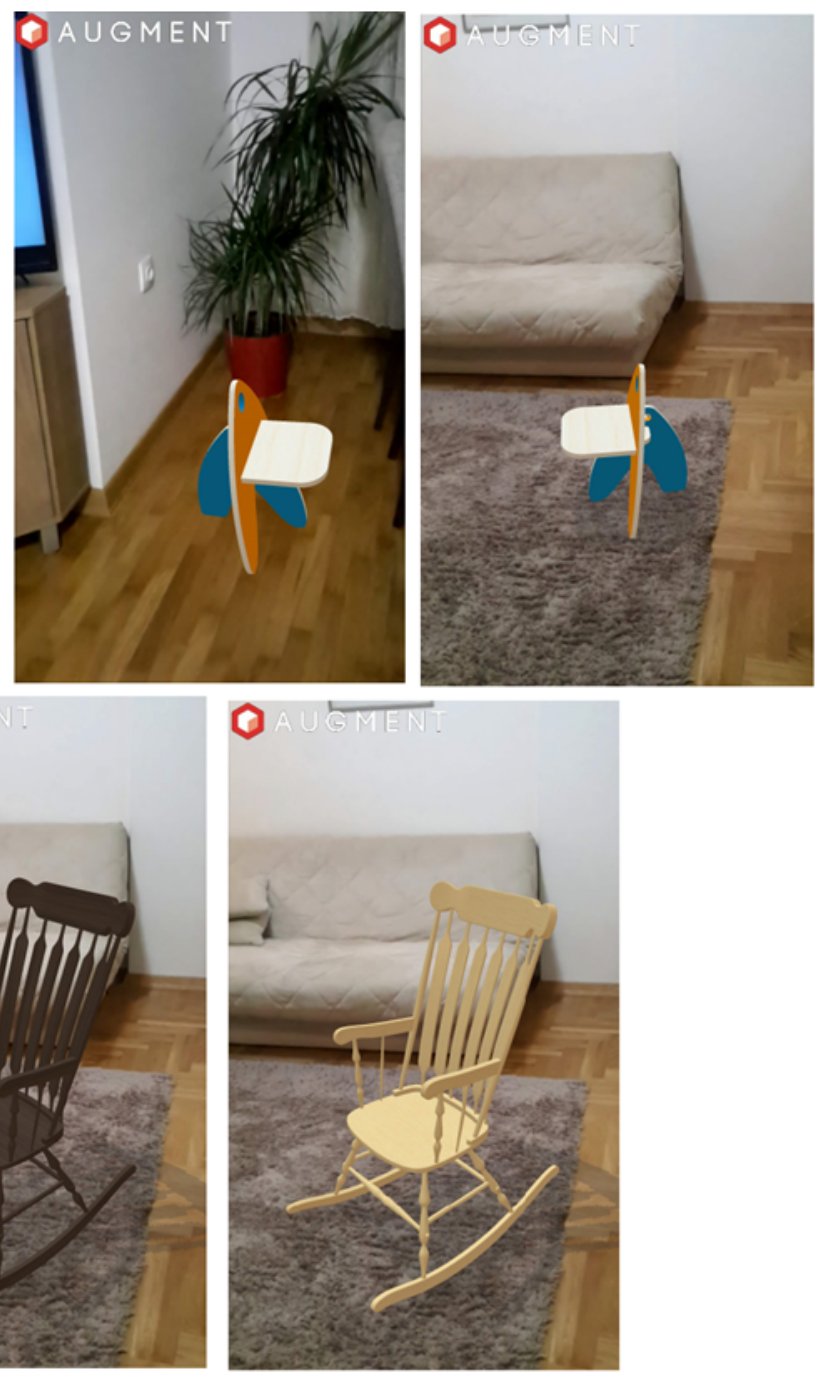

Слика 60 - Приказ на производите во категоријата „Столици“ на сајтот AUGmebel во аугментирана реалност 

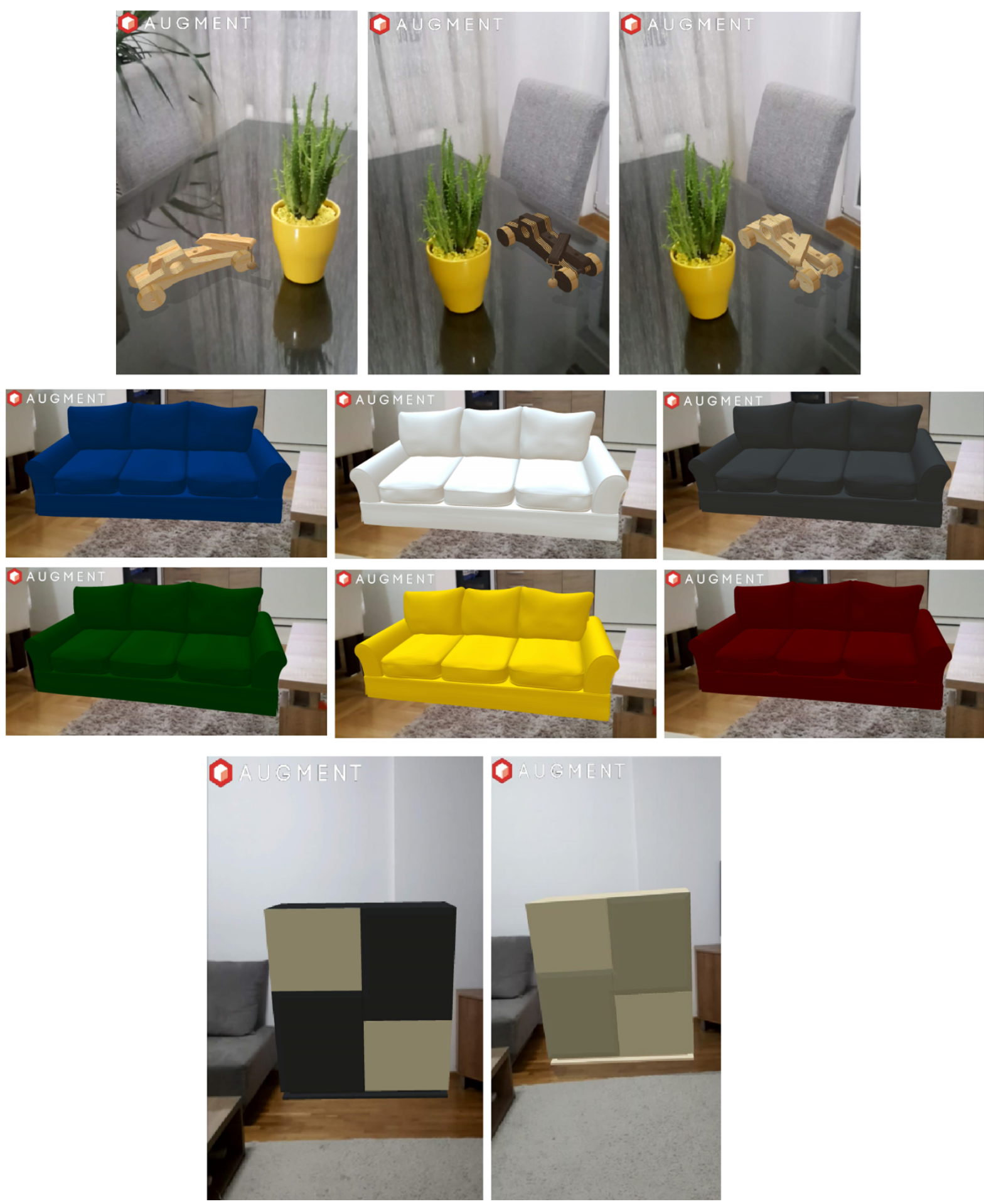

Слика 61 - Приказ на производите во категоријата „Останати производи“ на сајтот AUGmebel во аугментирана реалност 


\section{9. Анализа на искуствата при купување со вградена аугментираната реалност и резултати од истражувањето}

По изработката на сајтот за онлајн продажба на мебел AUGmebel и имплементацијата на аугментираната реалност на истиот, беше спроведено истражување на потенцијалните корисници. Целта на ова истражување беше да се испита познавањето и користењето на аугментираната реалност од страна на македонските купувачи, искуствата кои би ги имале при купување со аугментирана реалност (на сајтот AUGmebel), перципираните предности и недостатоци на аугментираната реалност, како и задоволството на корисниците.

Анкетата беше составена од 16 прашања, затворени и отворени, со еднократен и повеќекратен избор, како и прашања со оценување на понудени опции со оценка од 1 до 5. Сите прашања од анкетата се прикажани во Прилог 1, додека графичкиот приказ на резултатите од анкетата е прикажан во Прилог 2.

Анкетата беше спроведена на 37 интернет корисници кои купиле производ онлајн.

Според TGI (Target Group Index $)^{37}$ - најголемо независно лиценцирано меѓународно истражување на потрошувачите, кое покрива повеќе од 50 земји во светот, а во кое е вклучена и Р.С.Македонија, од испитаниците на возраст од 15-74 години, кои купиле нешто онлајн во последните 12 месеци (2018 година) - 54,9 \% се жени, додека 45,1\% се мажи.

Па соодветно на овие податоци беше одбрана и половата застапеност на испитаниците во истражувањето, па 56,8 \% од испитаниците беа од женски пол, додека $43,2 \%$ од машки пол.

Најголем број од испитаниците $86,5 \%$ беа од Скопје, додека по 2,7\% од испитаниците беа од Велес, Штип, Струга, Куманово и Тетово.

Во однос на возраста, најзастапена возрасна група во истражувањето $(62,2 \%)$ е 25-34 години, која е и примарна целна група за купување на мебел. Следна најзастапена возрасна група е 35-44 години со 21,6\%. Возрасната група со 18-24 години е застапена со само 5,4\%, бидејќи според одговорите во истражувањето, овие корисници не учествуваат во процесот на донесување на одлука за купување на мебел.

Според TGI истражувањето застапеноста на возрасната група 45-54 во онлајн продажбите во изминатите 12 месеци е 14,4\%, додека застапеноста на возрасната група над 55 години е само $3,59 \%$, па соодветно на ова, застапеноста на испитаниците од овие возрасни групи

\footnotetext{
${ }^{37}$ Macedonia TGI (Target Group Index) consumer measurment 2018 - Mediana Adria, 2018
} 
во истражувањето е помало -беа вклучени 8,1\% испитаници од возрасната група 45-54 и $2,7 \%$ испитаници од возрасната група над 55 години. ${ }^{38}$

На прашањето колку често купуваат онлајн, најголем процент од испитаниците - 45,9\% одговорија дека често купуваат онлајн, блиску следени од 43,2\% од испитаниците кои одговорија дека ретко купуваат онлајн. Секогаш кога има можност онлајн купуваат само $10,8 \%$ од испитаниците, додека во анкетата не беа вклучени испитаници кои никогаш не купуваат онлајн, бидејќи целта беше истражувањето да биде спроведено само врз онлајн купувачи.

На прашањето „Дали учествувате во процесот на донесување одлука за купување на мебел во домот? “ 89,2\% од испитаниците одговорија дека учествуваат, а 10,8\% од испитаниците одговорија дека не учествуваат. Испитаниците кои одговорија дека не учествуваат се сите испитаници од возрасната група 18-24 и два корисника од возрасната група 25-34, што е и разбирливо земајќи во предвид дека корисниците од 18-24 години не се главен таргет за купување на мебел. Поголемиот број од нив живеат со своите родители и најчесто не учествуваат во донесувањето на одлука за купување на мебел. Затоа оваа целна група е значително помалку застапена во истражувањето.

На прашањето „Дали знаете што е аугментирана реалност?“, голем дел од испитаниците $64,9 \%$ одговорија дека знаат, додека $35,1 \%$ од испитаниците не знаат што е аугментирана реалност. Ова ни покажува дека свесноста за аугментираната е реалност е голема, па нејзиното прифаќање од страна на потенцијалните корисници би било многу полесно и побрзо.

На прашањето „Дали сте користеле агументирана реалност за купување на производ?“, само 5,4\% од испитаниците одговорија дека користеле (за купување во странство), додека останатите 94,6\% одговорија дека немаат користено.

Од ова можеме да заклучиме дека иако свесноста за аугментираната реалност е многу висока, 94,6\% од испитаниците ја немаат користено во онлајн купување на производи, па компанијата која прва ќе ја имплементира аугментираната реалност при продажба на производи во Р.С.Македонија, ќе ги искористи предностите од тоа прва да ја примени и да им го збогати искуството на потрошувачите при купувањето. Секако за добро искуство на корисниците и придобивки од аугментираната реалност, многу е битно таа да е добро имплементирана - да нуди реален приказ на производите, како и да биде соодветно промовирана, за потенцијалните клиенти да се информирани за достапноста на истата.

Целта на следните прашања беше да се спореди веројатноста за купување на мебел онлајн без аугментирана реалност, со аугментирана реалност и со агументирана реалност и плус

\footnotetext{
${ }^{38}$ Macedonia TGI 2018 (Total Population) - Mediana Adria, 2018. Прашање: „Дали сте купиле нешто онлајн во последните 12 месеци“.
} 
гаранција за враќање на парите доколку производот не изгледа онака како што бил прикажан во аугментирана реалност. Испитаниците требаше да ја оценат веројатноста за купување на мебел онлајн на овие опции, со оценка од 1 до 5, каде 1 е најмалку веројатно, а 5 најмногу веројатно дека би купиле.

Подолу е табела со просечната оценка која овие прашања ја добија во истажувањето:

\begin{tabular}{|l|c|}
\hline \multicolumn{1}{|c|}{ Прашање } & $\begin{array}{c}\text { Просечна } \\
\text { оценка }\end{array}$ \\
\hline Која е веројатноста од 1 до 5 дека ќе купите мебел онлајн? & 2.30 / 5 \\
\hline $\begin{array}{l}\text { Која е веројатноста од } 1 \text { до 5 дека ќе купите мебел оnline, доколку } \\
\text { претходно пробате како би изгледал во вашиот дом со опцијата } \\
\text { аугментирана реалност ? }\end{array}$ & 3.73 / 5 \\
\hline $\begin{array}{l}\text { Која е веројатноста од } 1 \text { до 5 дека ќ купите мебел онлајн со опцијата } \\
\text { Аугментирана реалност, доколку имате гаранција за целосно враќање на } \\
\text { парите, доколку испорачаниот производ не изгледа онака како што бил } \\
\text { прикажан во аугментирана реалност? }\end{array}$ & $4.54 / 5$ \\
\hline
\end{tabular}

Табела 1 - Приказ на просечните оцени за веројатноста за купување мебел онлајн без и со АР

Веројатноста за купување мебел онлајн без аугментирана реалност е многу ниска - 2,3/5.

На прашањето „Која е веројатноста од 1 до 5 дека ќе купите мебел онлајн“ најголем број од испитаниците - 54\% одговорија дека не е веројатно или е малку веројатно дека ке купат мебел онлајн, следено од 37,8\% од испитаниците кои не беа сигурни дали би купиле мебел онлајн. Само 8,1\% од испитаниците одговорија дека е најмногу веројатно или многу веројатно дека би купиле мебел онлајн.

Според TGI истражувањето, мебел онлајн купиле 5,2\% од испитаниците, што е блиску до резултатите кои ги добивме од истажувањето - 8,1\%.

Веројатноста за купување мебел онлајн се зголемува за $62 \%$ доколку се користи аугментирана реалност, па просечната оценка на веројатност за купување мебел онлајн со користење на аугментирана реалност е 3,73/5.

На прашањето „Која е веројатноста од 1 до 5 дека ќе купите мебел онлајн, доколку претходно го пробате како би изгледал во вашиот дом со опцијата аугментирана реалност“, 56,8 \% од испитаниците одговорија дека е многу веројатно. 13,5\% одговорија дека е најмногу веројатно дека би купиле. 21,6\% не се сигурни, додека само 8,1\% најверојатно не би купиле. 
Сумарно, 70,3\% од испитаниците одговориле дека е најмногу веројатно или многу веројатно да купат мебел онлајн, доколку користат аугментирана реалност.

Веројатноста за купување мебел онлајн се зголемува за дополнителни $22 \%$, доколку освен што ќе користат аугментирана реалност при купувањето, купувачите ќе добијат и гаранција за целосно враќање на парите доколку производот не изгледа како што бил прикажан во аугментирана реалност, па просечната оценка на веројатност на купување мебел онлајн на ова прашање е 4,54/5.

На прашањето „, Која е веројатноста од 1 до 5 дека ќе купите мебел онлајн со опцијата Аугментирана реалност, доколку имате гаранција за целосно враќње на парите, доколку испорачаниот производ не изгледа онака како што бил прикажан во аугментирана реалност?“ - 64,9\% од испитаниците одговорија дека е најмногу веројатно дека ке купат мебел онлајн. 24,3\% од испитаниците одговорија дека е многу веројатно дека би купиле, а $10,8 \%$ од испитаниците не се сигурни. Никој од испитаниците не одговори дека не би купил онлајн.

Според ова, дури 89,2\% од испитаниците одговориле дека е најмногу веројатно или многу веројатно да купат мебел онлајн, доколку користат аугментирана реалност и имаат гаранција за враќање на парите доколку производот не изгледа како што бил прикажан во аугментираната реалност.

Од ова можеме да заклучиме дека користењето на аугментираната реалност значително ја зголемува веројатноста за купување мебел онлајн од 8,1\% на 70,3\%. Додека користењето на аугментирана реалност и гаранција за враќњье на парите доколку производот не изгледа како што е прикажан во аугментираната реалност ја зголемува веројатноста за купување на мебел онлајн од 70,3\% на 89,2\%.

Според ова доколку одредена компанија сака да ги зголеми онлајн продажбите на мебел, треба да ја имплементира аугментираната реалност на својот вебсајт, а доколку е во можност, да гарантира и целосно враќање на парите доколку производот не изгледа како што бил прикажан во аугментираната реалност, што не би било проблем доколку ЗД моделите на производите се добро изработени и имплементирани во аугментираната реалност.

Следното прашање бараше од испитаниците да оценат колку се согласуваат со наведените изјави со оценка од 1 до 5 (1 - Воопшто не се согласувам, 2 - Делумно не се согласувам, 3 Ниту се согласувам ниту не се согласувам, 4 - Делумно се согласувам, 5 - Целосно се согласувам). 


\begin{tabular}{|l|c|}
\hline \multicolumn{1}{|c|}{ Прашање } & $\begin{array}{c}\text { Просечна } \\
\text { оценка }\end{array}$ \\
\hline $\begin{array}{l}\text { Аугментираната реалност ми помага подобро да одберам која боја и материјал од } \\
\text { производот да го купам }\end{array}$ & 4.32 / 5 \\
\hline $\begin{array}{l}\text { Аугментираната реалност ми помага полесно да се одлучам кој производ да го } \\
\text { купам }\end{array}$ & $4.11 / 5$ \\
\hline $\begin{array}{l}\text { Аугментираната реалност ми помага да проверам дали производот ми одговара на } \\
\text { просторот }\end{array}$ & $4.65 / 5$ \\
\hline Аугментираната реалност е лесна за користење & $4.30 / 5$ \\
\hline $\begin{array}{l}\text { Би платил повисока цена за купување на мебел, доколку пред купување можам да } \\
\text { пробам како би изгледал во мојот дом со аугментирана реалност }\end{array}$ & $3.05 / 5$ \\
\hline
\end{tabular}

Табела 2 - Приказ на просечните оцени за тоа колку испитаниците се согласуваат со наведените тврдења

Тврдењето „Аугментираната реалност ми помага подобро да одберам која боја и материјал од производот да го купам“ доби просечна оценка 4,32/5, и е второ по ред тврдење со кое испитаниците најмногу се согласуваат.

Најголем број од испитаниците - 59\% целосно се согласуваат со тоа дека аугментираната реалност им помага подобро да одберат која боја и материјал од производот да го купат, $22 \%$ од испитаниците делумно се согласуваат, $13 \%$ не се сигурни, додека само $3 \%$ од испитаниците делумно не се согласуваат и $3 \%$ целосно не се согласуваат со ова тврдење.

Сумарно $81 \%$ од испитаниците се согласуваат (целосно или делумно) дека аугментираната реалност им помага подобро да одберат која боја и материјал од производот да го купат, додека само 6\% не се согласуваат (целосно и делумно).

Тврдењето „Аугментираната реалност ми помага подобро да одберам која боја и материјал од производот да го купам“ доби просечна оценка 4,11/5.

Најголем број од испитаниците 51\% делумно се согласуваат со тоа дека аугментираната реалност им помага полесно да се одлучат кој производ да го купат, $32 \%$ целосно се согласуваат. $14 \%$ не се сигурни, додека само $3 \%$ од испитаниците целосно не се согласуваат со оваа изјава. Нема испитаници кои делумно не се согласуваат со оваа изјава.

Сумарно $83 \%$ од испитаниците целосно или делумно се согласуваат дека аугментираната реалност им помага подобро да одберат која боја и материјал од производот да го купат, а само 3\% не се согласуваат.

Тврдењето „Аугментираната реалност ми помага да проверам дали производот ми одговара на просторот “ доби највисока просечна оценка од 4,65/5, што би ја издвоило оваа опција како најголема предност на аугментираната реалност. 
Најголем број од испитаниците - 73\% целосно се согласуваат со оваа изјава, 24\% делумно се согласуваат, додека само $3 \%$ од испитаниците воопшто не се согласуваат со оваа изјава. Нема испитаници кои делумно не се согласуваат или не се сигурни.

Сумарно 97\% од испитаниците целосно или делумно се согласуваат дека аугментираната реалност им помага да проверат дали производот им одговара на просторот.

Со ова се потврдува изборот на слоганот за сајтот AUGmebel - „Проверете како секој производ би изгледал во вашиот дом со аугментирана реалност“, бидејќи ја комуницира главната перцепирана предност на оваа технологија за потрошувачите.

Тврдењето „Би платил повисока цена за мебел доколку пред купување можам да пробам како би изгледал во мојот дом со аугментирана реалност“ доби просечна оценка од 3.05/5.

Целта на ова прашање беше да се испита колку користење на аугментираната реалност дава додадената вредност за корисниците која може да се одрази на цената на производите, односно дали испитаниците би платиле повисока цена за мебел, доколку пред купување можат да пробаат како би изгледал во нивниот дом со аугментирана реалност.

Најголем број од испитаниците $30 \%$ делумно се согласуваат со ова тврдење, $13 \%$ целосно се согласуваат, 22\% не се сигурни, 16\% воопшто не се согласуваат и $19 \%$ делумно не се согласуват.

Сумарно $43 \%$ од испитаниците се согласуваат (делумно или целосно) дека би платиле повисока цена за мебел доколку пред купување можат да пробаат како би изгледал во нивниот дом со аугментирана реалност. 35\% не се согласуваат (делумно и целосно), а $22 \%$ од испитаниците не се сигурни.

Ова значи дека 43\% од потенцијалните клиенти се спремни да платат повисока цена за производите кои би ги пробале во аугментирана реалност пред купувањето. Па продавачите на мебел кои ќе ја имплементираат опцијата за аугментирана реалност имаат можност да ги зголемат цените на производите, што би им донело зголемени профити.

Тврдењето „Аугментираната реалност е лесна за користење “ доби просечна оценка 4,30/5.

Најголем број од испитаниците - 53\% целосно се согласуваат дека аугментираната реалност е лесна за користење, 30\% делумно се согласуваат. 11\% не се сигурни, додека 3\% од испитаниците делумно не се согласуваат и $3 \%$ целосно не се согласуваат со оваа изјава.

Сумарно 83\% од испитаниците сметаат дека аугментираната реалност е лесна за користење, а само 6\% сметаат дека не е. 
Ова не води до заклучокот дека македонските компании не би имале проблеми и потешкотии при користењето на аугментираната реалност од страна на потенцијалните клиенти, бидејќи 83\% од испитаниците кои ја користеа аугментираната реалност имплементирана на сајтот AUGmebel, сметаат дека таа е лесна за користење.

100\% од испитаниците се согласија со прашањето „Дали сметате дека опцијата за аугментираната реалност е корисна и би било добро да се имплементира на сајтови за онлајн продажба на мебел?“.

Сите испитаници се согласија дека би било добро аугментираната реалност да се имплементира и на сајтови за продажба на други производи, освен мебел.

Сите испитаниците се согласија дека имплементирањето на опцијата за аугментирана реалност им го збогатува искуството при купување на мебел.

Од ова можеме да заклучиме дека сите испитаници сметаат дека опцијата за аугментирана реалност е корисна и им го збогатува искуството при купување на мебел, сакаат да ја видат имплементираната на сајтови за онлајн продажба на мебел, како и на сајтови за продажба на други производи.

Целта на следното прашање , Дали би преферирале да купите мебел од продавници кои ја нудат опцијата за аугментирана реалност, наспроти од продавници кои не ја нудат оваа опција?“ беше да се истражи дали аугментираната реалност генерира преференции за купување од компанијата која ја нуди, наспроти компаниите кои не ја нудат оваа опција.

Дури 83,8\% од испитаниците би преферирале да купат мебел од продавници кои ја нудат опцијата за аугментирана реалност, наместо од продавници кои не ја нудат оваа опција.

Доколку компаниите за продажба на мебел ја имплементираат аугментираната реалност, таа би ги диференцирала од конкуренцијата и би генерирала преференци кај целните потрошувачи, што би резултирало во зголемени продажби за компанијата.

Во анкетата беше вклучено и отворено прашање, кое не беше задолжително да се одговори, а кое бараше од испитаниците да споделат доколку имаат некоја сугестија или коментар во врска со примената на аугментираната реалност на сајтот AUGmebel.

95\% од испитаниците немаа сугестија или коментар, додека 5\% од испитаниците одговорија дека многу им се допаѓа идејата за аугментираната реалност, дека е добитна и се надеваат дека ќe се користи од страна на најголем дел од понудувачите на производи на пазарот. 
Како што можеме да заклучиме од истражувањето, свесноста за аугментираната реалност во Р.С. Македонија е висока (64,9\%), но и покрај тоа 94,6\% од испитаниците ја немаат користено оваа технологија при онлајн купувањето.

Во моментов веројатноста за купување на мебел онлајн е многу ниска $(8,1 \%)$, но доколку се имплементира опцијата за аугментирана реалност дури 70,3\% од испитаниците би купиле мебел онлајн. Доколку дополнително се воведе и гаранција за враќање на парите доколку производот не изгледа како што бил прикажан во АР дури 89,2\% од испитаниците би купиле мебел онлајн. Што значи дека АР технологијата значително ја намалува несигурноста и ја зголемува веројатноста за купување мебел онлајн.

97\% од испитаниците целосно или делумно се согласуваат дека аугментираната реалност им помага да проверат дали производот им одговара на просторот. 81\% се согласуваат дека АР им помага подобро да одберат која боја и материјал од производот да го купат, додека $83 \%$ од испитаниците се согласуваат дека АР им помага полесно да се одлучат кој производ да го купат. Со што се потврдува корисноста на оваа технологија за крајните корисници.

83\% од испитаниците се согласуваат дека аугментираната реалност е лесна за користење.

Сите испитаници сметаат дека опцијата за аугментирана реалност е корисна и им го збогатува искуството при купување на мебел. 100\% од испитаниците се согласуваат дека би било добро аугментираната реалност да се имплементира на сајтови за онлајн продажба на мебел, како и на сајтови за продажба на други производи.

$43 \%$ од испитаниците се согласуваат (целосно или делумно) дека би платиле повисока цена за мебел доколку пред купување можат да пробаат како би изгледал во нивниот дом со аугментирана реалност . Ова значи дека $43 \%$ од потенцијалните клиенти се спремни да платат повисока цена за производите кои би ги пробале во аугментирана реалност пред купувањето.

Доколку одредена компанија сака да ги зголеми онлајн продажбите на мебел, како и да ги зголеми профитите, треба да ја имплементира опцијата за приказ на производите во аугментираната реалност на својот веб-сајт. 


\section{0. Заклучок}

Технологијата на аугментирана реалност која овозможува виртуелен приказ на $3 Д$ модели на производи во реални средини, значително влијае врз подобрување на визуелното разбирање на купувачите при онлајн претставувањето на производите. Според резултатите од истражувањето, сите испитаници се согласуваат дека опцијата за аугментирана реалност е корисна и им го збогатува искуството при купување, и сите би сакале оваа технологија да им биде достапна на сајтови за онлајн продажба на мебел, како и на сајтови за продажба на други производи.

Аугментираната реалност придонесува кон збогатување и подобрување на искуството на потрошувачите. 97\% од испитаниците во истражувањето се согласуваат дека аугментираната реалност им помага да проверат дали производот им одговара на просторот. $81 \%$ се согласуваат дека АР им помага подобро да одберат која боја и материјал од производот да го купат, додека $83 \%$ се согласуваат дека аугментираната реалност им помага полесно да се одлучат кој производ да го купат.

Придобивките од имплементирањето на аугментирана реалност во продажбата се многубројни и големи, додека трошоците за нејзината имплементација не се високи, особено доколку се користи Augment за имплементирање на оваа технологија. Она што е потребно при имплементацијата е ЗД моделите на производите да се добро изработени, по што на едноставен начин дизајнерите можат да ги доработат за имплементирање во аугментирана реалност. Многу лесно можат да се додадат дополнителни опции за конфигурирање на различни бои и материјали во кои производите се достапни, а кои ќе овозможат корисниците лесно да пробаат различни варијанти на производите во аугментирана реалност.

Многу битен елемент при имплементација на аугментираната реалност за зголемување на онлајн продажбите, кој не смее да се заборави е и добар, интуитивен и репонзивен дизајн на веб-сајт кој ќе овозможи лесна имплементација на АР технологијата, а воедно и ке го поддржи процесот за онлајн купување. Начинот за користењето на аугментираната реалност треба да биде добро објаснет на веб-сајтот, со слики од секој чекор во процесот, за да може секој корисник лесно да најде насоки за користење.

Аугментираната реалност ги зголемува преференциите за купување производи од компанијата која би ја понудила оваа опција и значително влијае врз зголемување на онлајн продажбите. Зголемувањето на онлајн продажбите за сметка на офлајн продажбите би водело да заштеда на трошоци за компанијата и зголемени профити. Додека преференциите за купување од компанијата која ја нуди АР опцијата води до можност за превземање на купувачи од конкуренцијата и дополнителни продажби и профити за компанијата. 
Како што видовме од истражувањето, аугментираната реалност нуди можност за продажба на истите производи по повисоки цени, што би резултирало во повисоки профити за компанија.

Неминовно, аугментираната реалност ќе стане алатка за разликување помеѓу малопродажната конкуренција, обезбедувајќи вистинска вредност во областите на интеракции на потрошувачите, и ќе резултира во зголемени продажби и намалени стапки на враќање.

Предностите од имплементацијата на аугментираната реалност во продажбата се многубројни, од подобрување на искуството на купувачите и зголемено задоволство, до зголемен имиџ на компанијата, зголемени продажби и профити, па затоа им препорачувам на сите компании кои имаат можност да ја имплементираат, да го сторат тоа, особено компаниите за продажба на мебел.

Раните прифаќачи на оваа технологија ќе ја имаат и предноста да бидат перцепирани од потрошувачите и конкуренцијата како многу иновативни компании и лидери на пазарот во користење на технологија.

Иако придобивките од оваа технологија се многубројни, сепак треба многу да се внимава при нејзината имплементацијата, бидејќи лошата имплементација на ЗД моделите во аугментираната реалност може да има многу негативни импликации врз компанијата.

Доколку компаниите не се во можност добро да ја имплементираат аугментираната реалност и таа не нуди реален приказ на производите (несоодветни димензии, материјали и бои), моја препорака е воопшто да не ја имплементираат. Бидејќи главната цел на оваа технологија е да даде реалистичен приказ на производите и да ги намали недостатоците од немање на физички контакт при онлајн купувањето. Доколку ова не е случај, лошата имплементација би водела до голем број незадоволни корисници, што лошо ќе се одрази врз имиџот на компанијата, а воедно би резултирало во голем број вратени производи и дополнителни трошоци за компанијата.

Затоа при имплементирање на аугментираната реалност треба добро да се провери дали ЗД моделите на производите се добро изработени, доколку не се тие ќе треба да се корегираат. При имплементирање на ЗД моделите во аугментираната реалност треба да се внимава да не има промена во димензиите на моделите, доколку има, тие треба да се корегираат, за да бидат одговараат на реалните димензии на производот кој се продава. При додавање на дополнителни опции на материјали и бои во кои производот е достапен и кои можат да се користат за гледање на различните варијанти на производот во аугментирана реалност, мора да се внимава тие да соодветствуваат на реално достапните материјали и бои на производот. 
Аугментираната реалност е одлична алатка, која неминовно ќе има централно место во онлајн и офлајн продажбите во иднина. Моја препорака е сите компании кои имаат можност да ја имплементираат, да го сторат тоа, но ова да го направат професионално и внимателно да го тестираат приказот на сите производи и варијанти на производите во аугментирана реалност, пред да ја имплементираат, со цел да се осигура реалистичен приказ на физичките производи. Само добрата АР имплементација ќе им овозможи на компаниите да ги искористат многубројните предности кои технологијата на аугментирана реалност ги нуди. 


\section{1. Користена литература}

1. Cohen, K. Global eCommerce Sales, Trends and Statistics 2016, 2017

2. Saleh, K. Global Online Retail Spending - Statistics and Trends, 2017

3. Ovum report, The Future od E-commerce: The road to 2026, Vol 1, pp.9, 2016

4. Државен завод за статистика на Р.С.Македонија. Информатичко општество. Соопштение Број/No: 8.1.18.29: Користење информатичко- комуникациски технологии во домаќинствата и кај поединците, 2018 година. Октомври 2018

5. Katawetawaraks, Ch. Wang, Ch.L. Online Shopper Behavior: Influences of Online Shopping Decision, Asian Journal of Business Research, vol.7 no.2 pp. 67-69, 2011

6. Laudon, K.C. and Traver, C.G., E-Commerce Business. Technology. Society, 5th edition, Prentice Hall, New Jersey. 2009

7. Koo, D.M., Kim, J.J. and Lee, S.H., Personal values as underlying motives of shopping online. 2008

8. Comegys, C., Hannula, M. and Váisánen, J., Effects of consumer trust and risk on online purchase decisionmaking: A comparison of Finnish and United States students, International Journal of Management, vol. 26, no. 2, pp. 295-308. 2009

9. Prasad, C. and Aryasri, A., Determinants of shopper behavior in e-tailing: An empirical analysis", Paradigm, vol. 13, no. 1, pp.73-83. 2009

10. Wang, C.L., Ye, L.R., Zhang, Y. and Nguyen, D.D., Subscription to fee-based online services:What makes consumer pay for online content? Journal of Electronic Commerce Research, vol. 6, no. 4, pp.301-311. 2005.

11. Goldsmith, R.E. and Flynn, L.R., Bricks, clicks, and pix: apparel buyers use of stores, internet, and catalogs compared, International Journal of Retail \& Distribution Management, vol. 33,no. 4, pp.271-283. 2005

12. Lim, H. and Dubinsky, A.J., Consumers' perceptions of e-shopping characteristics: An expectancy-value approach, The Journal of Services Marketing, vol. 18, no. 6, pp. 500-513. 2004

13. T.L., Carr, C.L., Peck, J. and Carson, S. "Hedonic and utilitarian motivations for online retail shopping behavior," Journal of Retailing, vol. 77, no. 4, pp.511-535. 2001

14. Korgaonkar, P.A. Karson, E.J. The influence of perceived product risk on consumers'e-tailer shopping preference, Journal of Business and Psychology, vol. 22, no. 1, pp. 55-64. 2007

15. Bigné-Alcañiz, E., Ruiz-Mafé, C., Aldás-Manzano, J. and Sanz-Blas, S, Influence of online shopping information dependency and innovativeness on internet shopping adoption, Online Information Review, vol. 32, no. 5, pp. 648-667. 2008

16. Broekhuizen, T. and Huizingh, E, Online purchase determinants: Is their effect moderated by direct experience? Management Research News, vol. 32, no. 5, pp. 440-457. 2009

17. Dongre S., Dube S. \& Patil, P. - Home Decor Shopping Using Augmented Reality; International Journal of Computer Science, and Engineering (IJCSE); - Vol. 5, Issue 2, Feb, pp. 15-22, 2016

18. Brito, Pedro \& Stoyanova, Jasmina \& Gonçalves, Ricardo \& Coelho, António. Real-time Augmented Reality Pemo Platform for Exploring Consumer Emotional Responses with Shopping Applications. International Journal of Online Engineering (iJOE). 9. pp 41-43, 2013

19. Höllerer, T. \& K Feiner, S. Mobile Augmented Reality, Chapter 9, 2017 
20. Furness, T. The super cockpit and its human factors challenges. In Proc. Human Factors Society 30th Annual Meeting, pages 48-52, Santa Monica, CA. 1986

21. Mizell, D. Boeing's wire bundle assembly project. In Barfield, W. and Caudell, T.,editors, Fundamentals of Wearable Computers and Augumented Reality, pages 447-467. Lawrence Erlbaum Assoc, Mahwah, NJ. 2001

22. Thorp, E. O. The invention of the first wearable computer. In Proc. ISWC '98 (Second Int. Symposium on Wearable Computers), pages 4-8, 1998

23. Sawhney, N. and Schmandt, C. Speaking and listening on the run: Design for wearable audio computing. In Proc. ISWC '98 (Second Int. Symp. On Wearable Computers), pages 108-115, Cambridge, MA. 1998

24. Kiryakova, G., Angelova, N., Yordanova, L., The Potential of Augmented Reality to Change the Business; Trakia Journal of Sciences, Vol. 15, Suppl. 1, pp 394-401, 2017

25. Klamann, K., Krastev,S. Why Augmented Reality Will Be the Next Revolution in Retail; Strategy+Business; Consumer \& Retail; Issue 87, 2017

26. Regenbrecht, H., Baratoff, G., \& Wilke, W., Augmented reality projects in the automotive and aerospace industries, IEEE Computer Graphics and Applications, 25(6), 48-56, 2005.

27. Williams II, D. Augment, Foundations and Future of Augmented Reality and Ecommerce: How augmented reality will impact online retail, pp. 9, 2016

28. Zhao,X. Shi, You, C. X. Zong, C. Analysis of Mental Workload in Online Shopping: Are Augmented and Virtual Reality Consistent; Frontiers in Psychology ,pp-8, 2017

29. Retail Perceptions Report, The Impact of Augmented Reality on Retail, 2016

30. Javornik,A. Augmented reality: Research agenda for studying the impact of its mediacharacteristics on consumer behaviour, Journal of Retailing and Consumer Services. 30:252-261." 2016

31. Bonetti F., Warnaby G., Quinn L. Augmented Reality and Virtual Reality in Physical and Online Retailing: A Review, Synthesis and Research Agenda. In: Jung T., tom Dieck M. (eds) Augmented Reality and Virtual Reality. Progress in IS. Springer, Cham, pp 119-132. 2017.

32. Brody, A. B. \& Gottsman, E J. Pocket BargainFinder: A handheld device for augmented commerce, International Symposium on Handheld and Ubiquitous Computing. Springer Berlin Heidelberg. 1999

33. Pachoulakis, I. \& Kapetanakis, K. Augmented reality platforms for virtual fitting rooms, The International Journal of Multimedia \& Its Applications, 4.4:35. 2012

34. Dacko, S. G. Enabling smart retail settings via mobile augmented reality shopping apps, Technological Forecasting and Social Change. 2016

35. Teo, T. S. H. \& Pian, Y. A contingency perspective on Internet adoption and competitive advantage, European Journal of Information Systems, 12(2):78-92. 2003

36. Poushneh, A.Z. Vasquez-Parraga, Customer Dissatisfaction and Satisfaction with Augmented reality in Shopping and Entertainment, vol.30, pp-97-119, 2017

37. Macedonia TGI (Target Group Index) consumer measurment reaserch. Mediana Adria, 2018

38. Macedonia TGI 2018 (Total Population) - Mediana Adria, 2018. Прашање: „Дали сте купиле нешто онлајн во последните 12 месеци“. 


\section{2. Прилози}

\section{1 Прилог 1: Анкета на корисници}

1. Колку често купувате онлајн?
a. Секогаш кога има можност
b. Често
c. Ретко
d. Никогаш

2. Дали учествувате во процесот на донесување одлука за купување на мебел во домот?
a. Да
b. $\mathrm{He}$

3. Која е веројатноста од 1 (најмалку веројатно) до 5 (најмногу веројатно) дека ќе купите мебел онлајн?

$\begin{array}{lllll}1 & 2 & 3 & 4 & 5\end{array}$

4. Дали знаете што е аугментирана реалност?
a. Да
b. $\mathrm{He}$

5. Дали сте користеле аугментирана реалност при купување на производ?
a. Да
b. $\mathrm{He}$

\section{Информација пред одговарање на следните прашања}

Ве молам пред одговарање на следните прашања, да го посетите сајтот https://augmebel.wixsite.com/home кој го изработив за оваа намена. На сајтот пробајте барем еден производ во аугментирана реалност, преку кликнување на линкот „ВИДИ ВО АУГМЕНТИРАНА РЕАЛНОСТ“ на страната со производот, потоа одговорете на следните прашања.

Предлог линк за директно гледање на производ во аугментирана реалност https://agmt.it/m/bu1sy74p - на овој линк треба да кликнете на црвеното копче View 
in your space - за да ви се отвори производот во аугментирана реалност преку Augment програмата и да го видите во реални димензии во вашата околина.

Доколку анкетата ја пополнувате од компјутер, ќе треба на мобилен да ја симнете апликацијата Augment и преку неа да го скенирате QR кодот за отворање на производот во аугментирана реалност.

6. Која е веројатноста од 1 (најмалку веројатно) до 5 (најмногу веројатно) дека ќе купите мебел online, доколку претходно пробате како би изгледал во вашиот дом со опцијата аугментирана реалност ?

$\begin{array}{lllll}1 & 2 & 3 & 4 & 5\end{array}$

7. Која е веројатноста од 1 (најмалку веројатно) до 5 (најмногу веројатно) дека ке купите мебел онлајн со опцијата Аугментирана реалност, доколку имате гаранција за целосно враќање на парите, доколку испорачаниот производ не изгледа онака како што бил прикажан во аугментирана реалност?

$\begin{array}{lllll}1 & 2 & 3 & 4 & 5\end{array}$

8. Дали би преферирале да купите мебел од продавници кои ја нудат опцијата за аугментирана реалност, наспроти од продавници кои не ја нудат оваа опција?

a. Да

b. $\mathrm{He}$

9. Ве молам одберете колку се сложувате со изјавите подолу, со оценка од 1 до 5 (1. Воопшто не се согласувам; 2. Делумно не се согласувам; 3. Ниту се согласувам, ниту не се согласувам; 4. Делумно се согласувам; 5. Целосно се согласувам)

a. Аугментираната реалност ми помага подобро да одберам која боја и материјал од производот да го купам

b. Аугментираната реалност ми помага полесно да се одлучам кој производ да го купам

c. Аугментираната реалност ми помага да проверам дали производот ми одговара на просторот

d. Би платил повисока цена за купување на мебел, доколку пред купување можам да пробам како би изгледал во мојот дом со аугментирана реалност

е. Аугментираната реалност е лесна за користење 
10. Дали сметате дека опцијата за аугментираната реалност е корисна и би било добро да се имплементира на сајтови за онлајн продажба на мебел?
a. Да
b. $\mathrm{He}$

11. Дали сметате дека би била добро аугментираната реалност да се имплементира и на сајтови за продажба на други производи, освен мебел?
a. Да
b. $\mathrm{He}$

12. Дали имплементирањето на опцијата аугментирана реалност би ви го збогатила искуството при купување на мебел?
a. Да
b. $\mathrm{He}$

13. Ве молам пишете ни доколку имате некоја сугестија или коментар во врска со применета на аугментираната реалност на сајтот Augmebel.

14. Колку години имате?
а. $18-24$
b. $25-34$
c. $35-44$
d. $45-54$
е. Над 55

15. Вашиот пол е?
a. Машки
b. Женски

16. Во кој град живеете? 


\section{2 Прилог 2 : Графички приказ на резултатите од анкетата}

\section{Колку често купувате онлајн?}

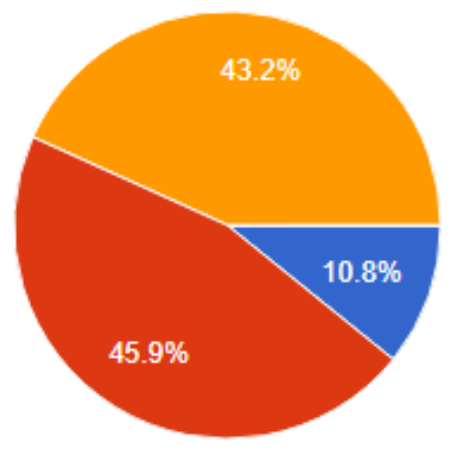

Секогаш кога има можност

Често

Ретко

Никогаш

Графикон 1 - Приказ на сумарните одговори на прашањето „Колку често купувате онлајн“

\section{Дали учествувате во процесот на донесување одлука за купување} на мебел во домот?

37 responses

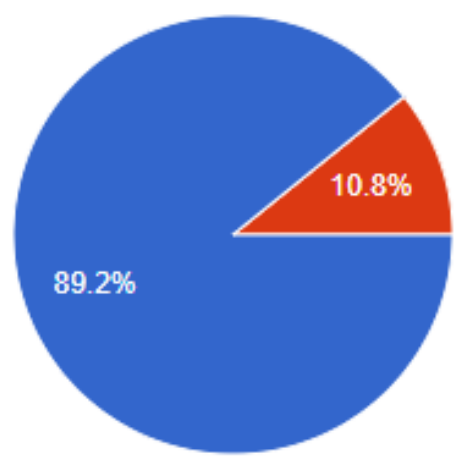

Да

$\mathrm{He}$

Графикон 2 - Приказ на сумарните одговори на прашањето „Дали учествувате во проиесот на донесување одлука за купување на мебел во домот?"“ 
Која е веројатноста од 1 до 5 дека ќе купите мебел онлајн?

37 responses

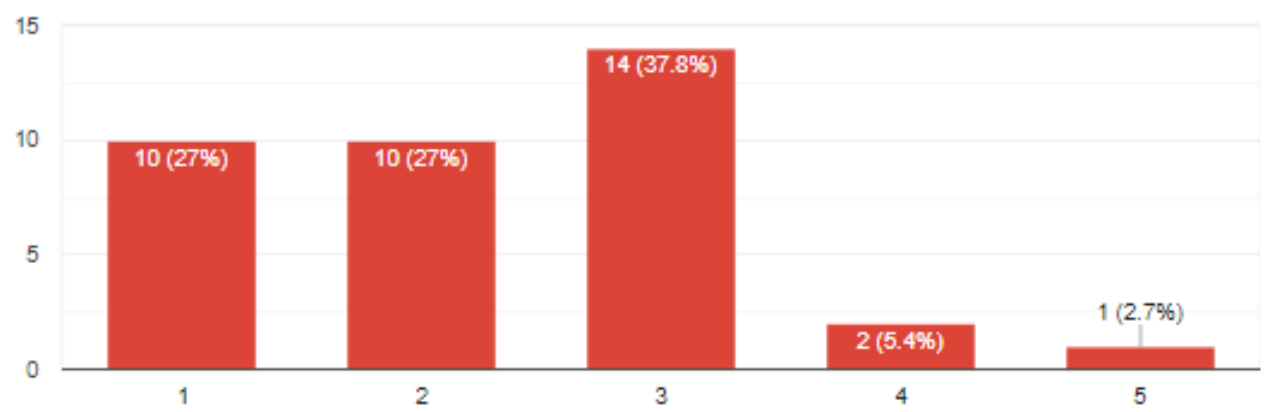

Графикон 3- Приказ на одговорите на прашањето „Која е веројатноста од 1 до 5 дека ке купите мебел онлајн “(1 најмалку веројатно, 5 најмногу веројатно)

\section{Дали знаете што е аугментирана реалност?}

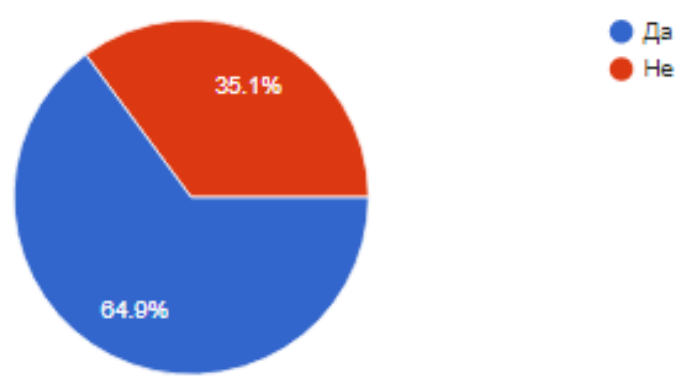

Дали сте користеле аугментирана реалност при купување на производ?

37 responses

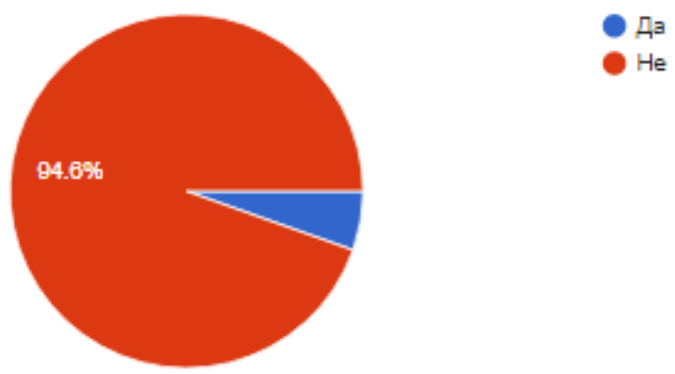

Графикон 4 - Приказ на сумарните одговори на прамањето ,, Дали знаете што е аугментирана реалност? “ 
Графикон 5 - Приказ на сумарните одговори на прашањето „Дали сте користеле агументирана реалност при купување на производ?“"

\section{Која е веројатноста од 1 до 5 дека ќе купите мебел online, доколку претходно пробате како би изгледал во вашиот дом со опцијата аугментирана реалност ?}

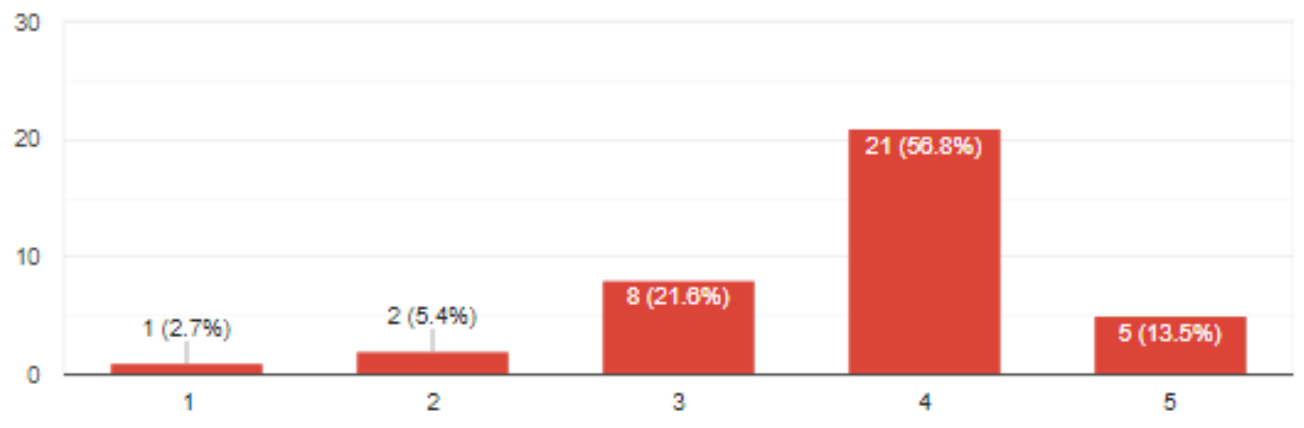

Графикон 6 - Приказ на одговорите на прашањето „Која е веројатноста од 1 до 5 дека ке купите мебел онлајн, доколку претходно го пробате како би изгледал во вашиот дом со опиијата аугментирана реалност "

Која е веројатноста од 1 до 5 дека ќе купите мебел онлајн со опцијата Аугментирана реалност, доколку имате гаранција за целосно враќање на парите, доколку испорачаниот производ не изгледа онака како што бил прикажан во аугментирана реалност?

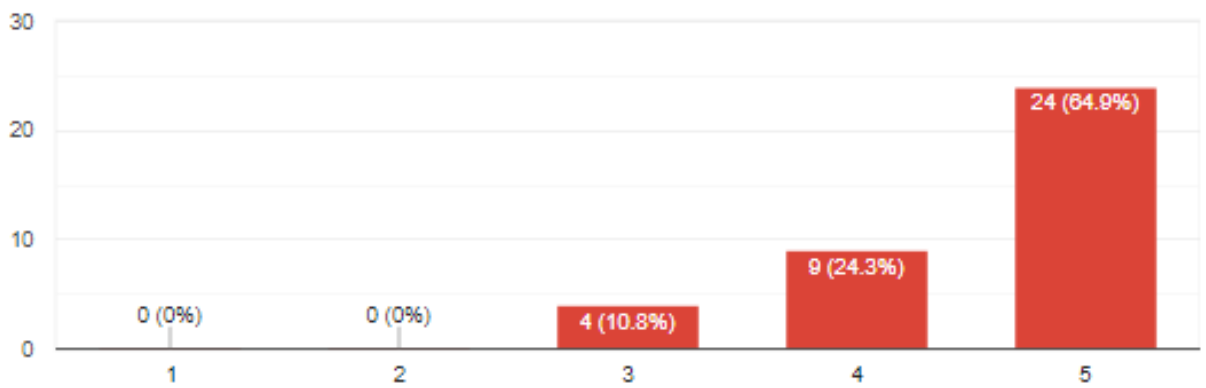

Графикон 7- Приказ на одговорите на прашањето „, Која е веројатноста од 1 до 5 дека ке купите мебел онлајн со опичјата Аугментирана реалност, доколку имате гараницја за цеелосно враќање на парите, доколку испорачаниот производ не изгледа онака како што бил прикажан во аугментирана реалност? “ 
Дали би преферирале да купите мебел од продавници кои ја нудат опцијата за аугментирана реалност, наспроти од продавници кои не ја нудат оваа опција?

37 responses
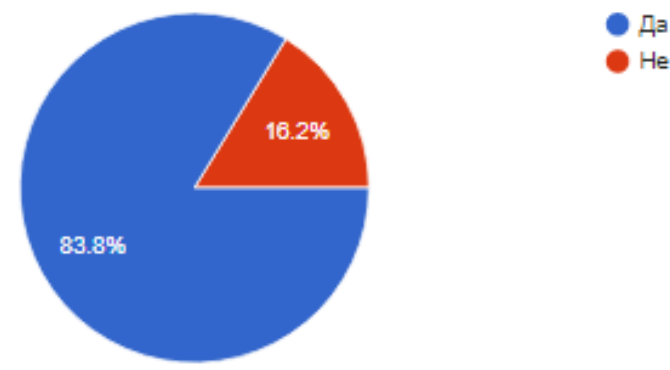

$\mathrm{He}$

Графикон 8 - Приказ на одговорите на прашањето „, Дали би преферирале да купите мебел од продавници кои ја нудат опицјата за аугментирана реалност, наспроти од продавници кои не ја нудат оваа опција?“”

\section{АУГМЕНТИРАНАТА РЕАЛНОСТ МИ ПОМАГА ПОДОБРО ДА ОДБЕРАМ КОЈА БОЈА И МАТЕРИЈАЛ ОД ПРОИЗВОДОТ ДА ГО КУПАМ}

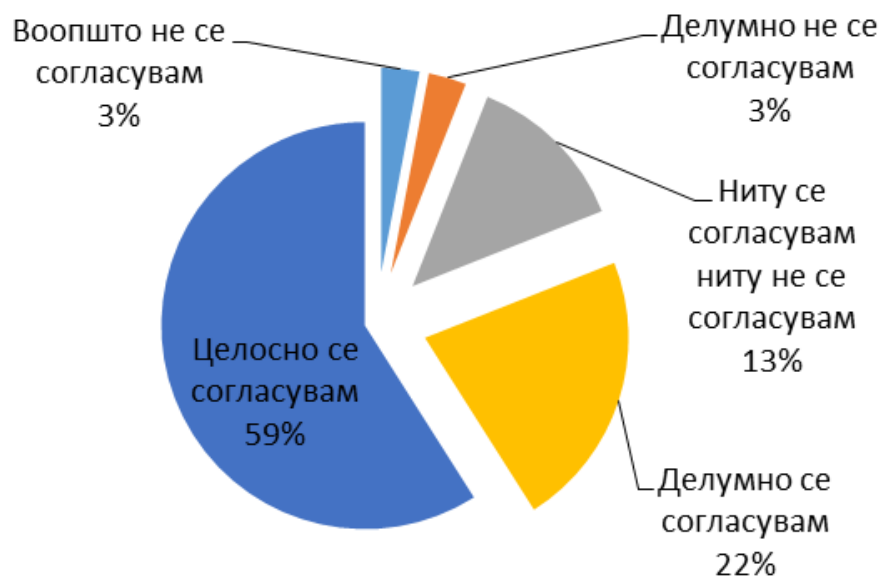

Графикон 9 - Приказ на резултатите на тврдењето „, Аугментираната реалност ми помага подобро да одберам која боја и материјал од производот да го купам?" 


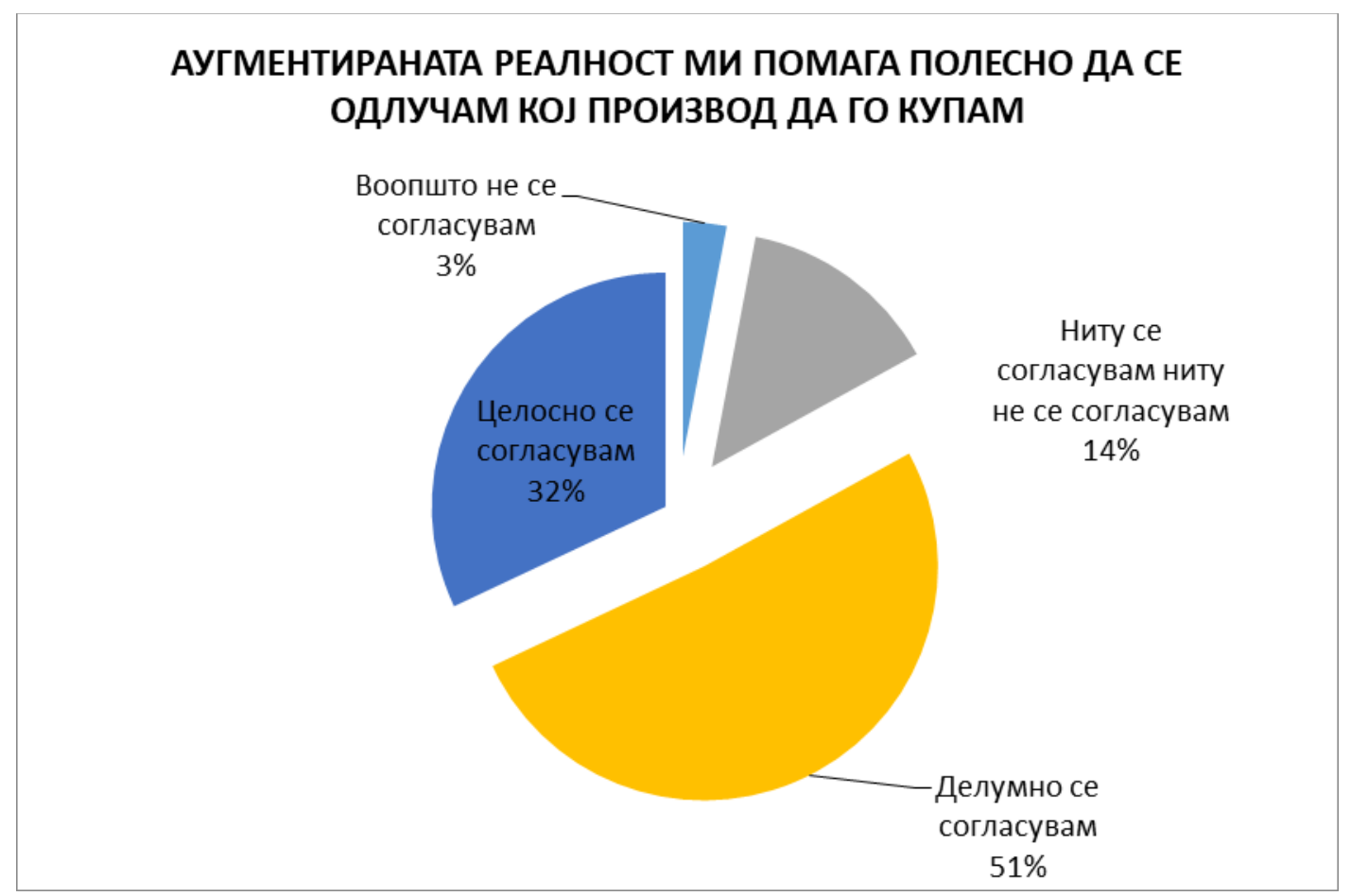

Графикон 10 - Приказ на резултатите на тврдењето „Аугментираната реалност ми помага полесно да се одлучам кој производ да го купам?"

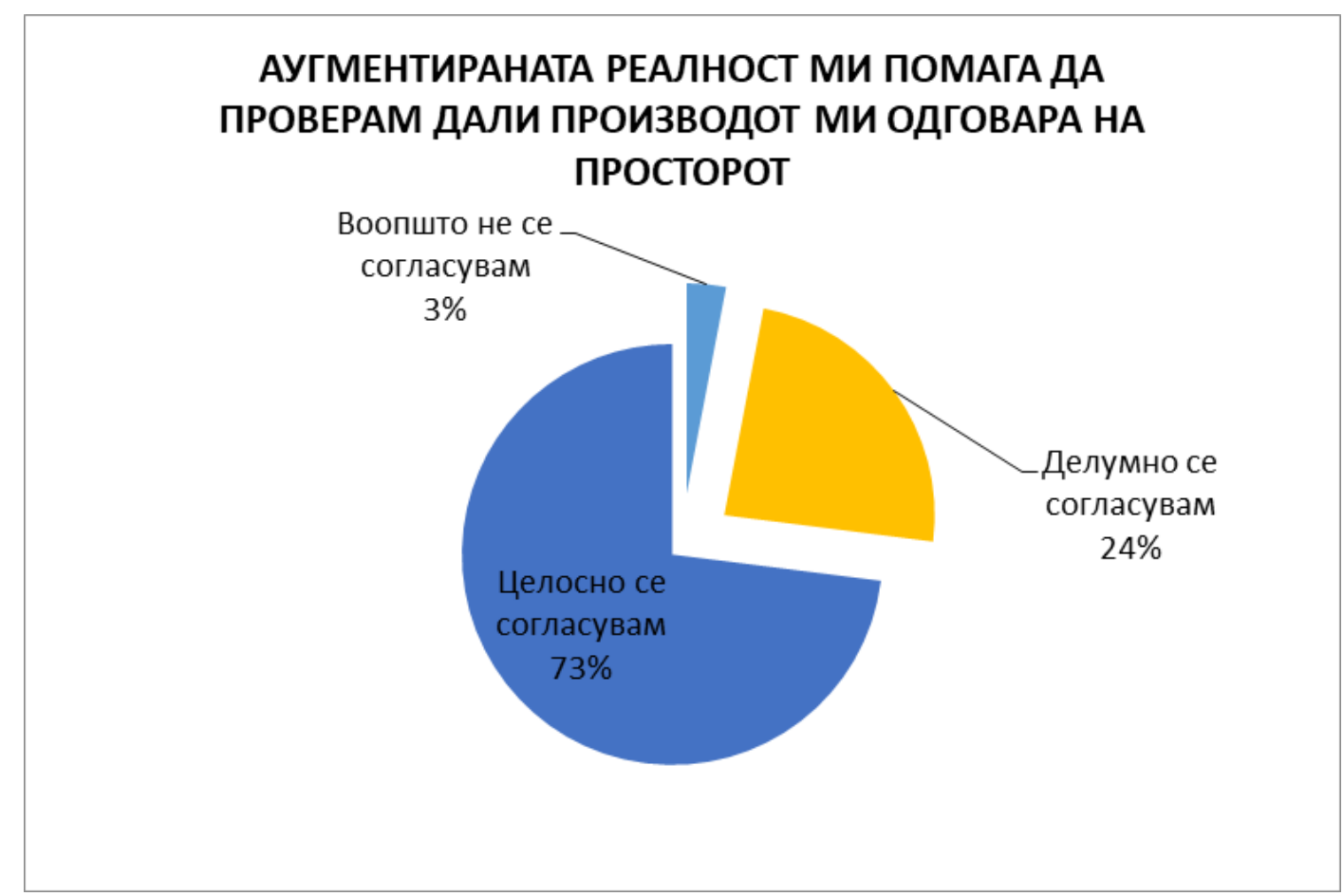

Графикон 11 - Приказ на резултатите на тврдењето „Аугментираната реалност ми помага да проверам дали производот ми одговара на просторот? “ 


\section{АУГМЕНТИРАНАТА РЕАЛНОСТ Е ЛЕСНА ЗА КОРИСТЕЊЕ}

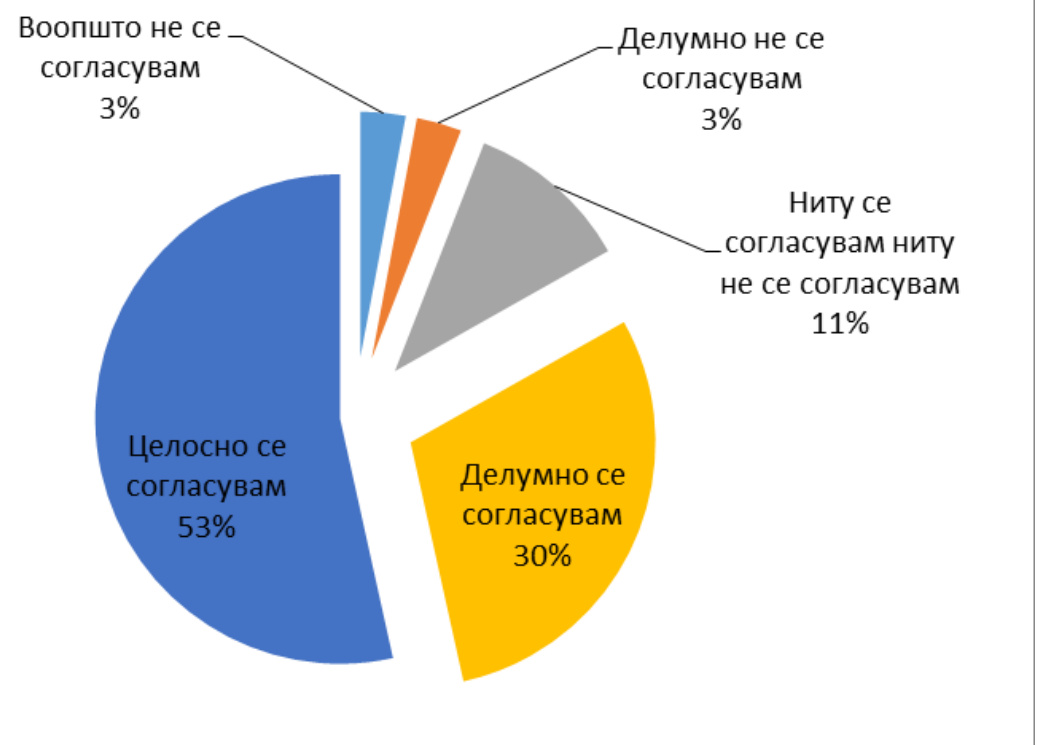

Графикон 12 - Приказ на резултатите на тврдењето „Аугментираната реалност е лесна за користење?“

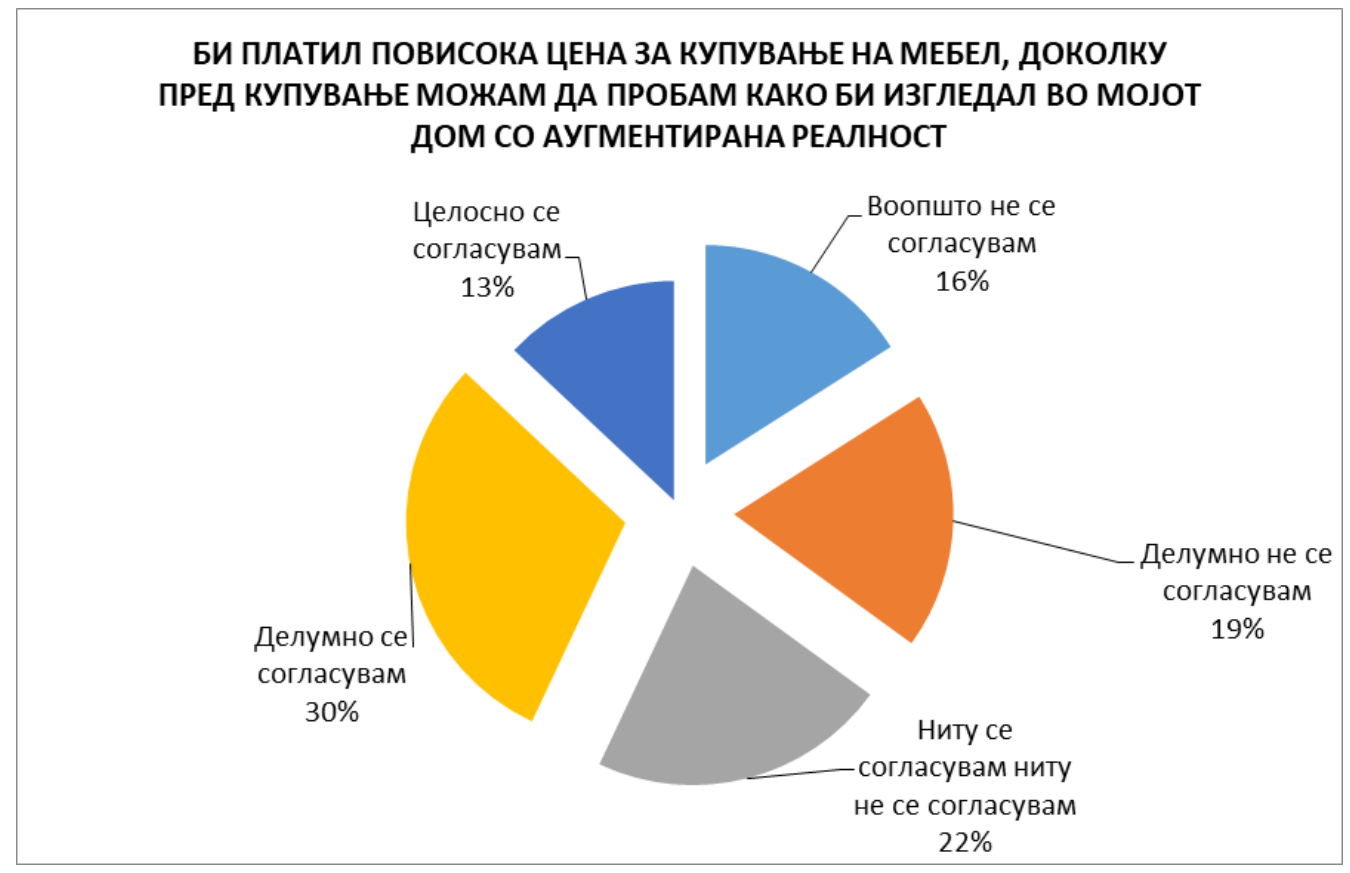

Графикон 13 - Приказ на резултатите на тврдењето,, Би платил повисока цена за купување на мебел, доколку пред купување можам да пробам како би изгледал во мојот дом со аугментирана реалност " 


\section{Дали сметате дека опцијата за аугментираната реалност е корисна и би било добро да се имплементира на сајтови за онлајн продажба на мебел? \\ 37 responses}

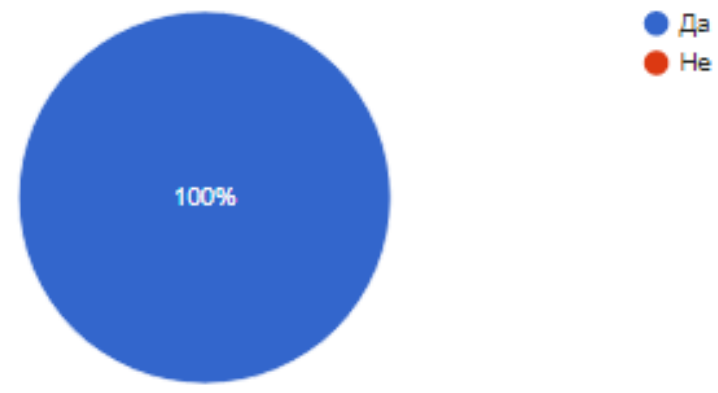

Графикон 14 - Приказ на одговорите на прашањето „Дали сметате дека опиијата за аугментираната реалност е корисна и би било добро да се имплементира на сајтови за онлајн продажба на мебел?“”

\section{Дали сметате дека би била добро аугментираната реалност да се имплементира и на сајтови за продажба на други производи, освен мебел? \\ 37 responses}

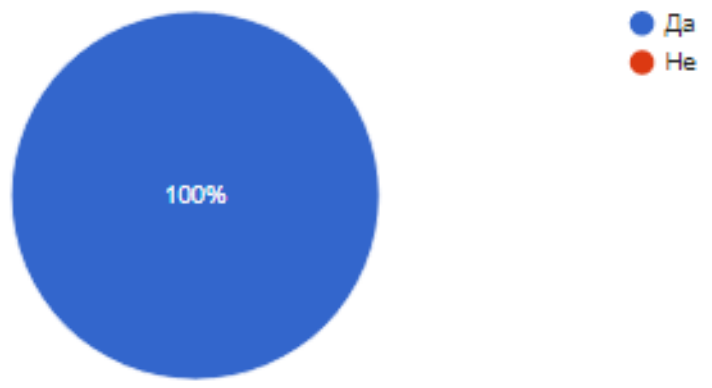

Графикон 15 - Приказ на одговорите на прашањето „Дали сметате дека би била добро аугментираната реалност да се имплементира и на сајтови за продажба на други производи, освен мебел?“” 


\section{Дали имплементирањето на опцијата аугментирана реалност би ви го збогатила искуството при купување на мебел? \\ 37 responses}

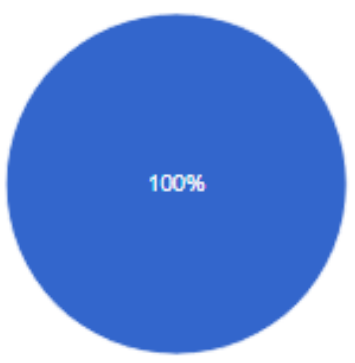

\section{- $\mathrm{Aa}$}

$\mathrm{He}$

Графикон 16 - Приказ на одговорите на прашањето „Дали имплементирањето на опицјата аугментирана реалност би ви го збогатила искуството при купување на мебел?"

\section{Ве молам пишете ни доколку имате некоја сугестија или коментар во врска со применета на аугментираната реалност на сајтот Augmebel. \\ 5 responses}

N/A

nemam

/

Одлично изгледа. Многу е практично и заштедува време. Да се надеваме дека ке се користи од страна на најголемиот дел на понудувачи на било какви производи на пазарот.

Mnogu jaka ideja, samo napred dobitno e!

Графикон 17 - Приказ на одговорите на прашањето „Ве молам пишете ни доколку имате некоја сугестија или коментар во врска со применета на аугментираната реалност на сајтот Augmebel “" 


\section{Колку години имате?}

37 responses

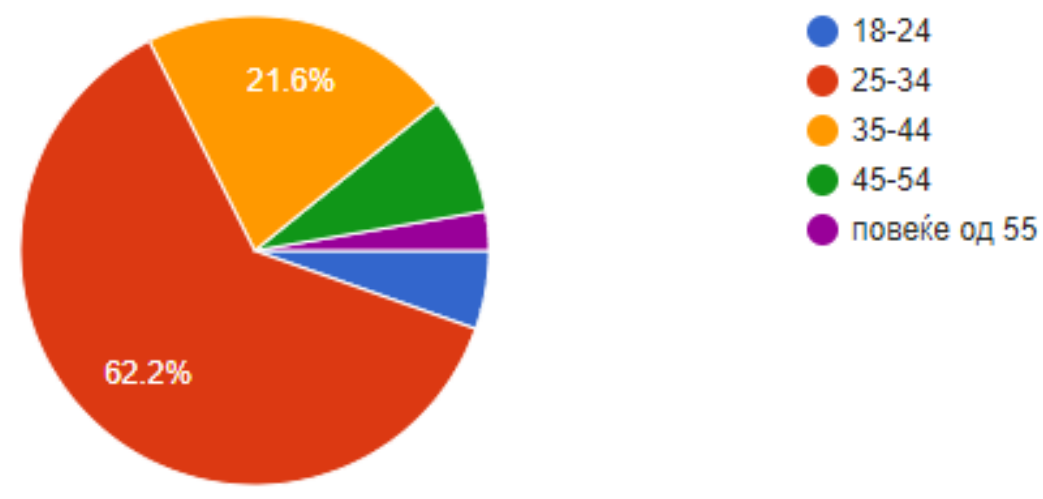

Графикон 18 - Застапеност на испитаниците по возраст

\section{Вашиот пол е}

37 responses

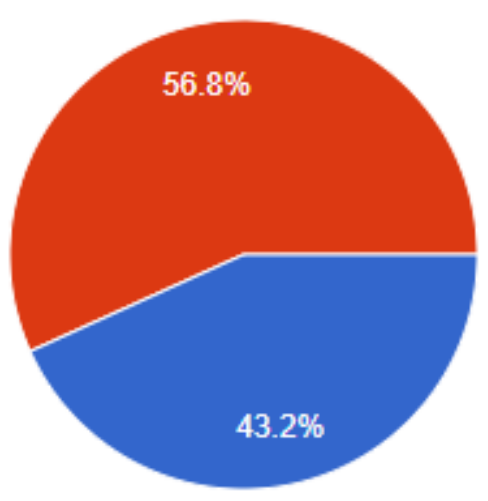

Машки

Женски

Графикон 19 - Полова застапеност на испитаниците 


\section{3 Прилог 3: Приказ на прилагодениот веб-сајт за потребите на Машински факултет}

Веб-сајтот го прилагодив и за потребите на Машински факултет, УКИМ, Скопје. Сајтот е достапен на овој линк https://augmebel.wixsite.com/mfs-proizvodi.

Подолу се наоѓаат слики од различни страни на веб-сајтот.

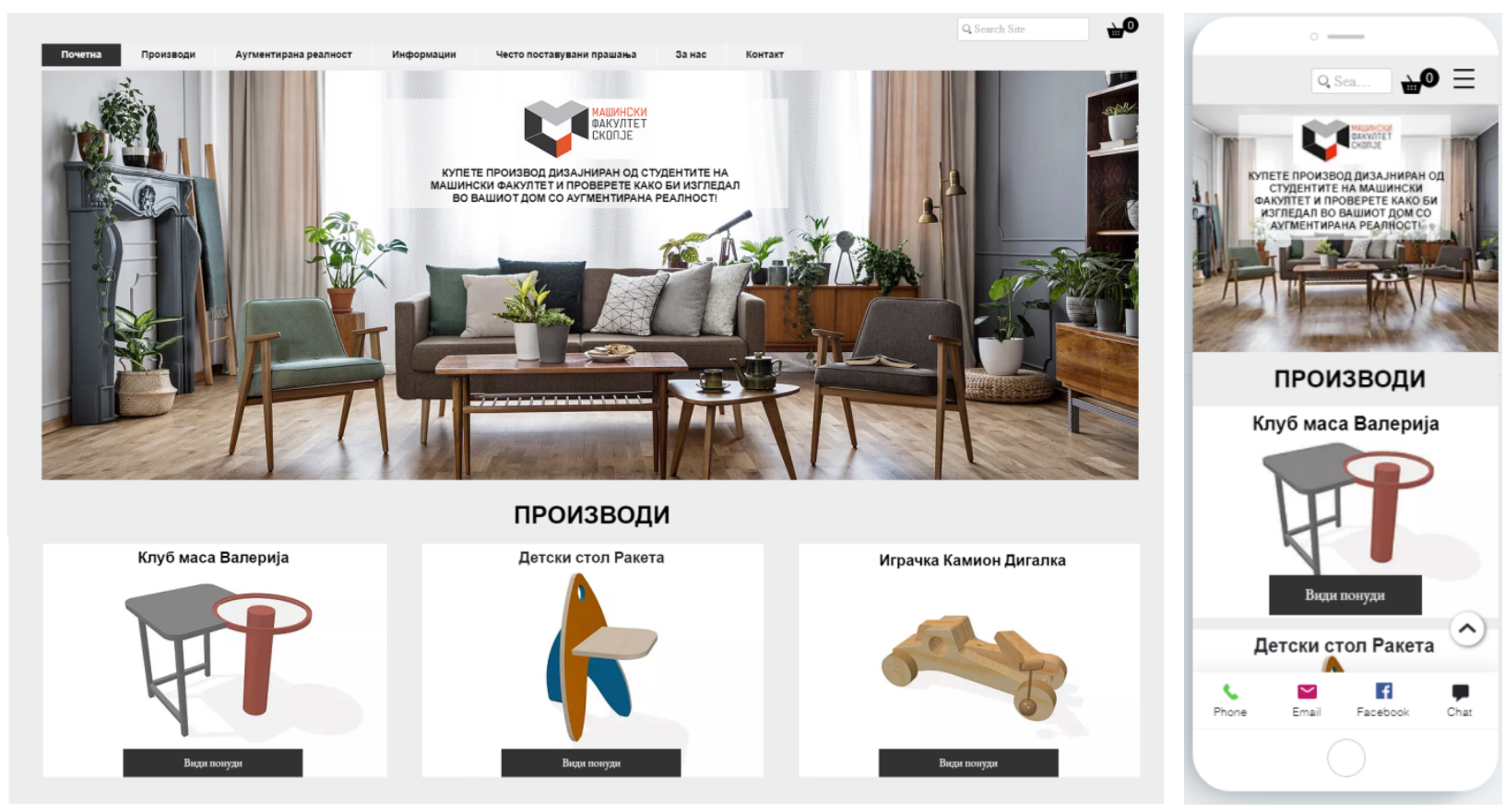

Слика 1- Приказ на почетната страна на десктоп и мобилната верзија на веб -сајтот 


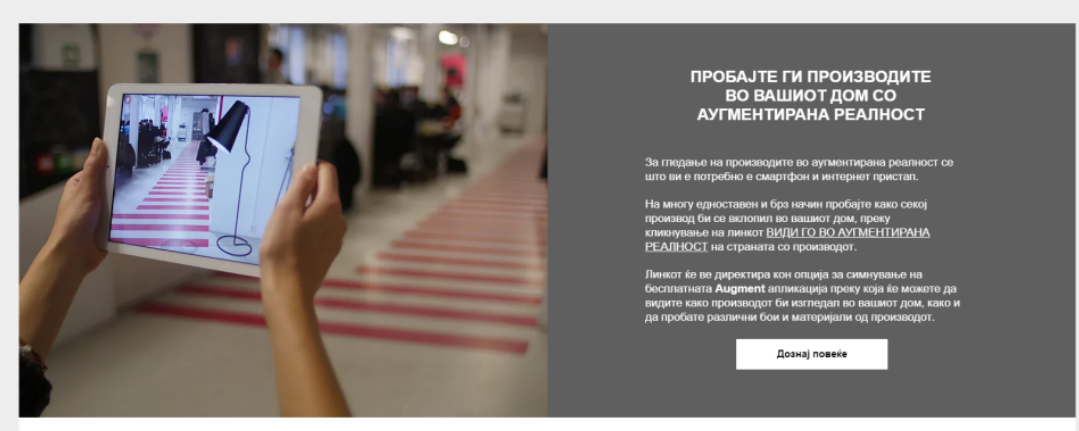

3 A H A C

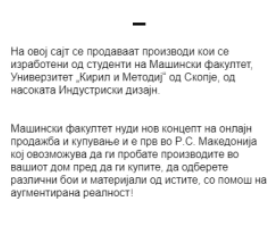

Ywreare во xynyeartero!
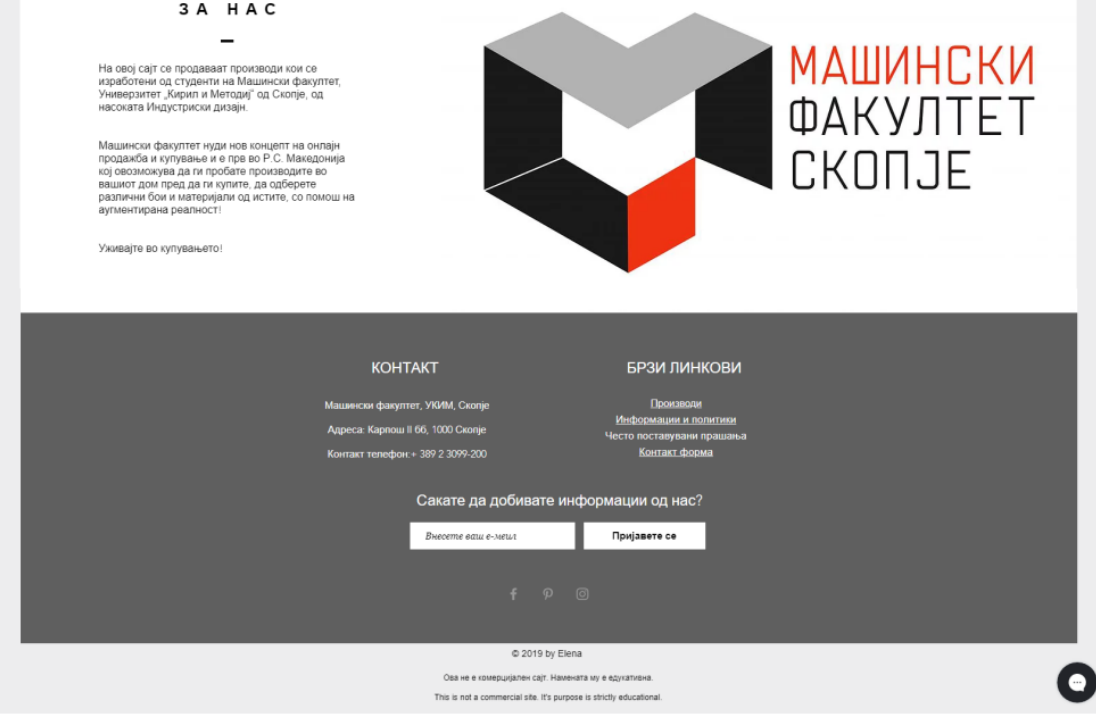

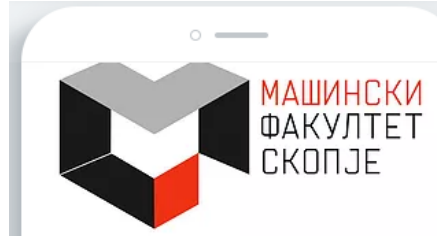

3 A H A C

$-$

На овој сајт се продаваат производи кои се изработени од студенти на Машински факултет, насоката Индустриски дизајн.

Машински факултет нуди нов концепт на онлајн продажба и купување и е прв во Р.С. Македониј кој овозможува да ги пробате производите во вашиот дом пред да гикапите, да одберете на аугментирана реапност!

Уживајте во купувањето!

\section{КОНТАКТ}

Машински факултет, УКИМ, Скопје Aдpeca: Карпош II 66, 1000 Cкопје Контакт телефон:+ 3892 3099-200 $\odot$ БРЗИ ЛИНКОВИ

$\underset{\text { Phone }}{\sim} \underset{\text { Email }}{\boldsymbol{f f}} \underset{\text { Chat }}{\boldsymbol{q}}$

Слика 2 - Приказ на делот „Аугментирана реалност“, „За нас“ и „Подножје на веб-сајтот (Footer)“ на почетната страна на десктоп и мобилната верзија на веб-сајтот

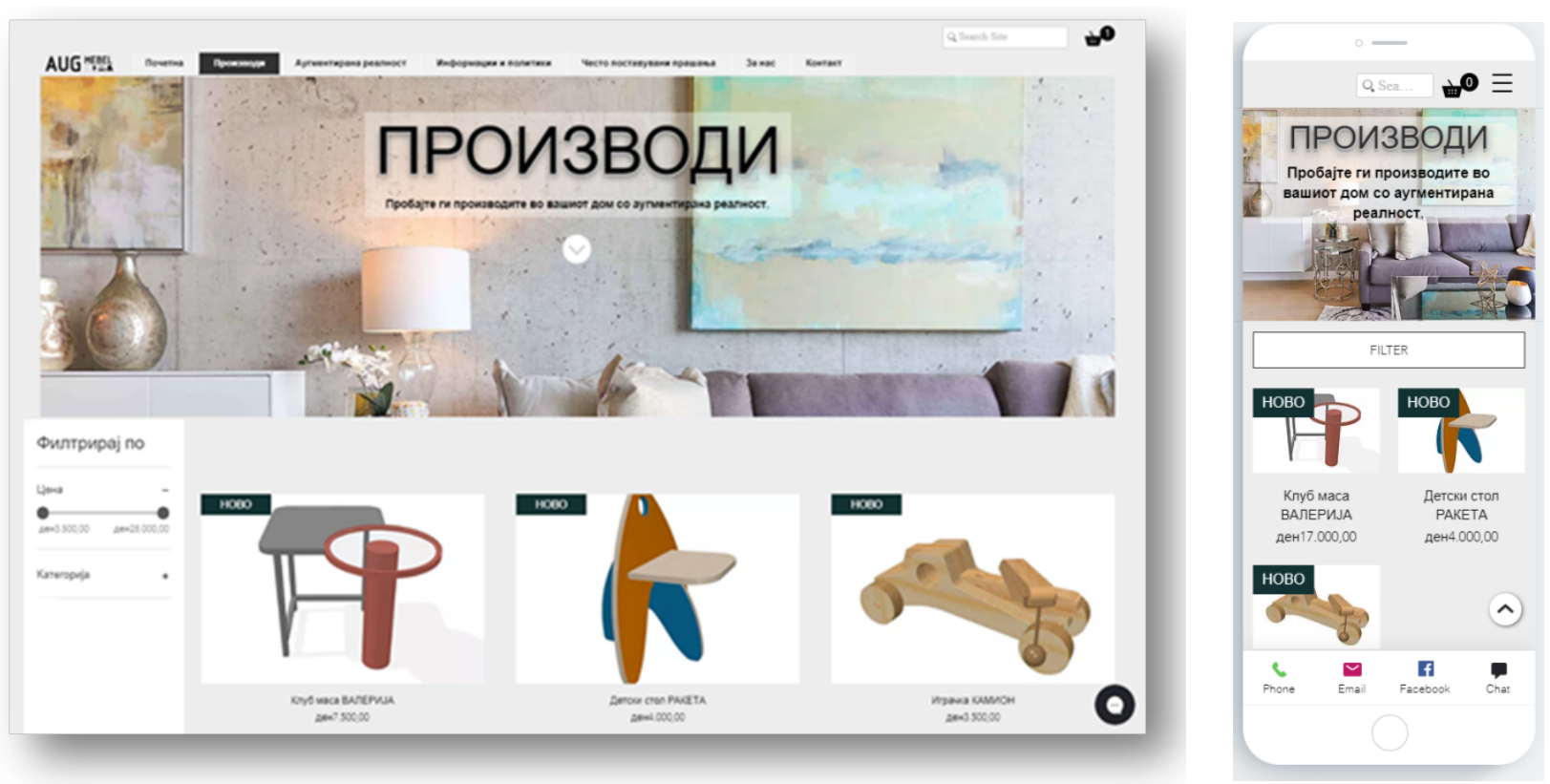

Слика 3- Приказ на десктоп и мобилната верзија на страната „Производи“ на веб-сајтот 


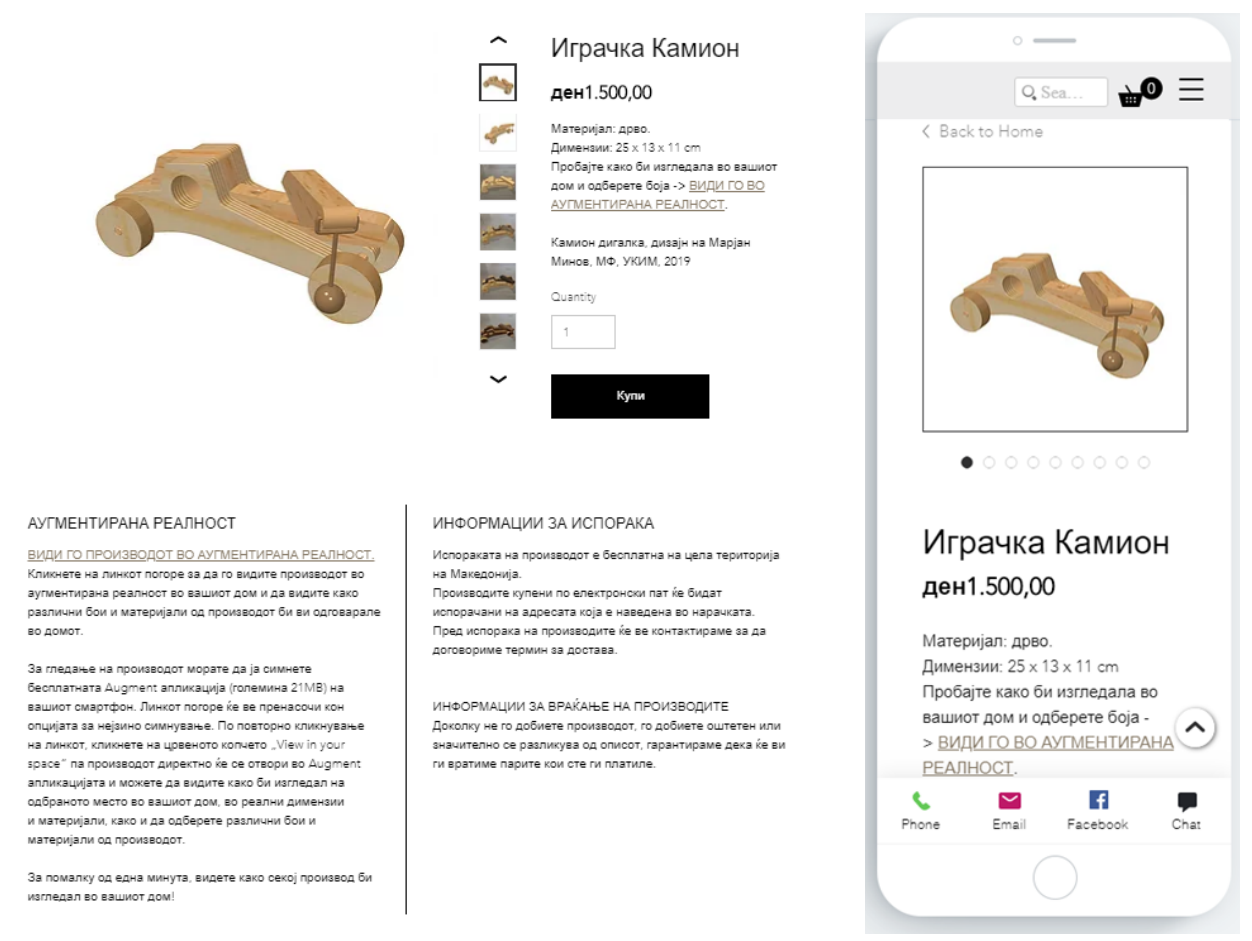

Слика 4 - Приказ на десктоп и мобилната верзија на конкретна страна со производ на веб-сајтот
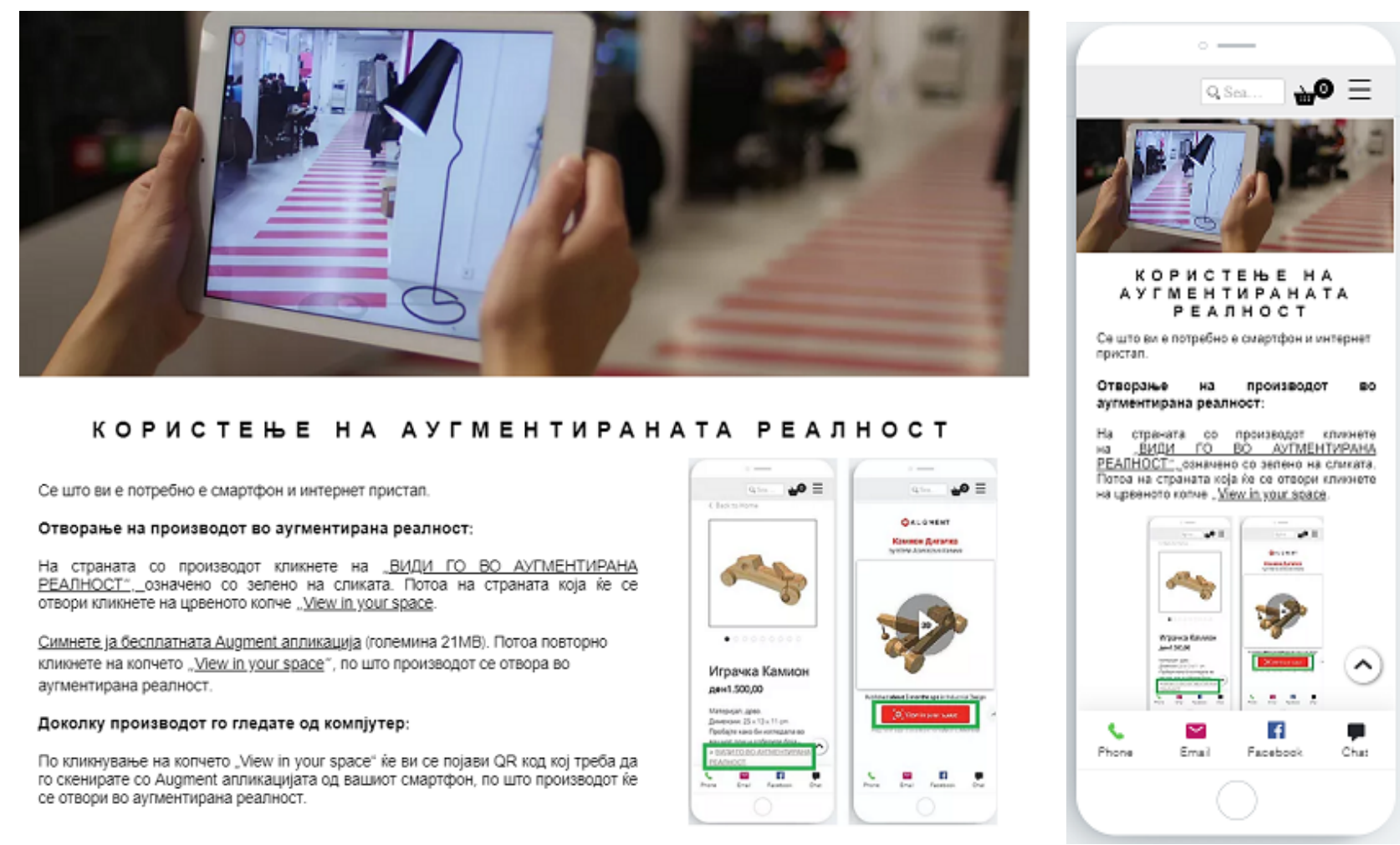

Слика 5 - Приказ на десктоп и мобилната верзија на страната „Аугментирана реалност“ н ва веб-сајтот 


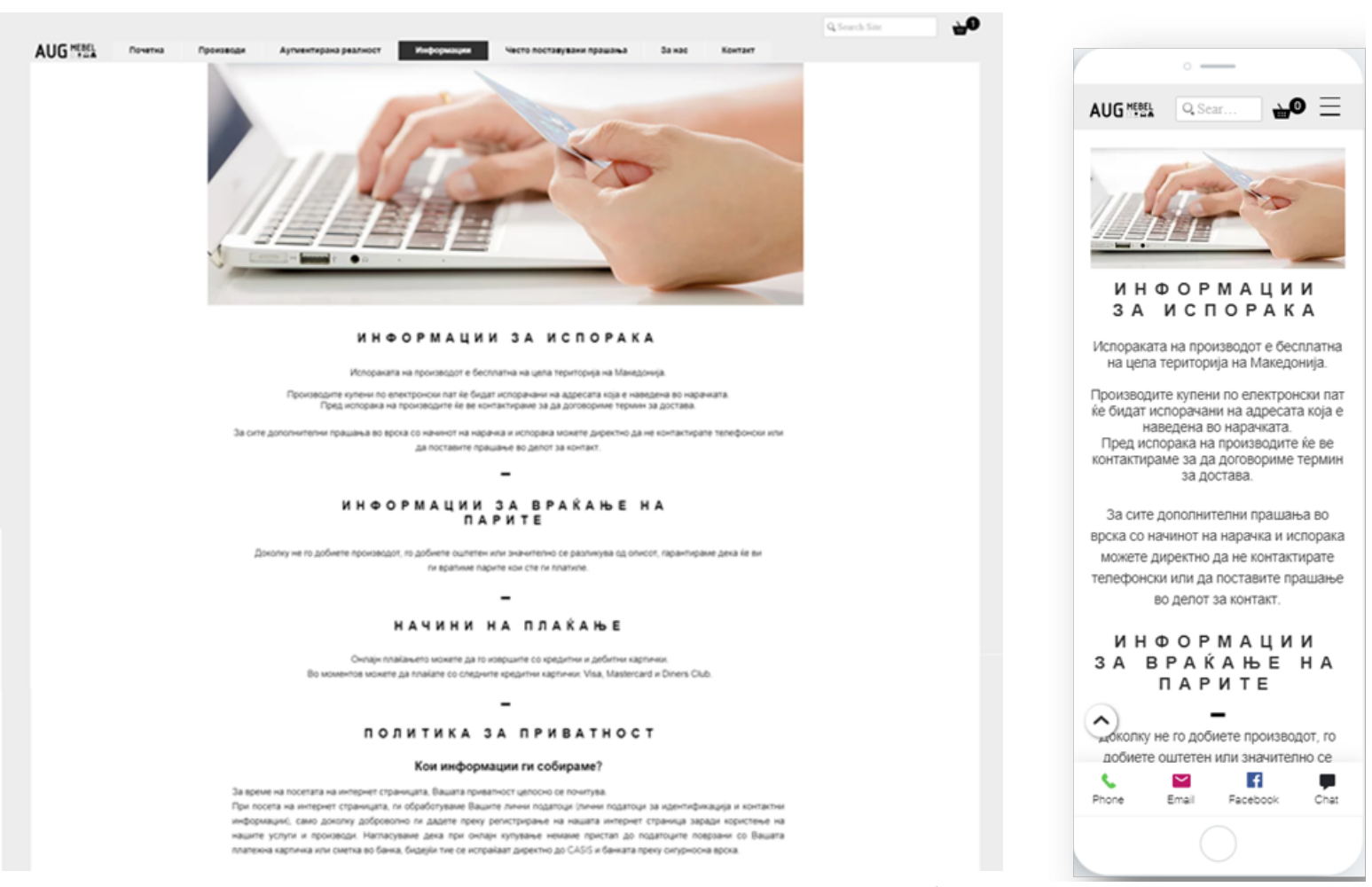

Слика 6- Приказ на десктоп и мобилната верзија на страната „Информации“ на веб-сајтот

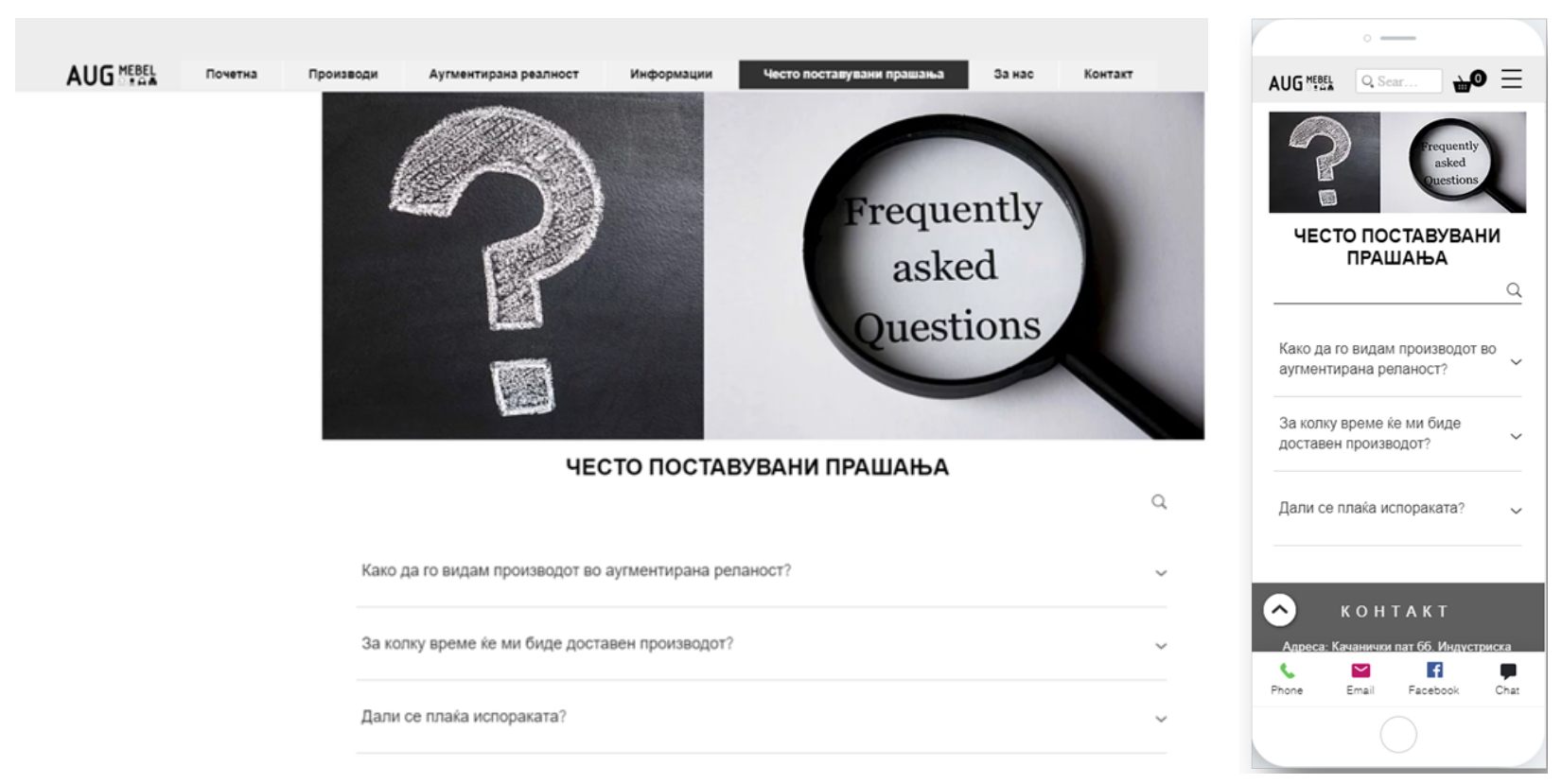

Слика 7 - Приказ на десктоп и мобилната верзија на страната „, Често поставувани прашања“ на веб-сајтот 


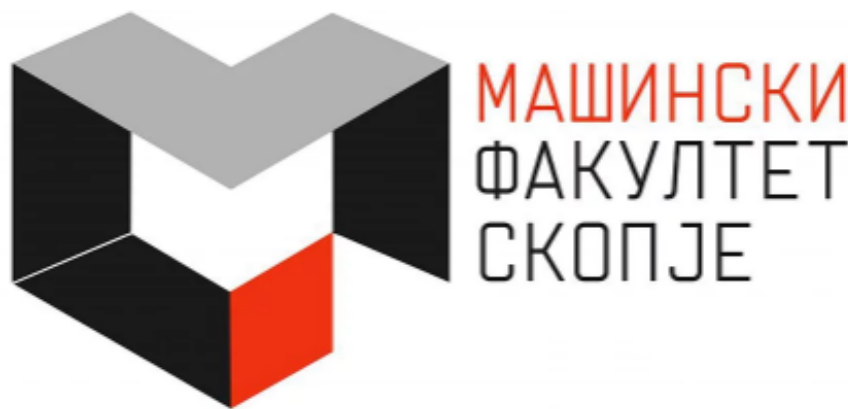

3 A H A C

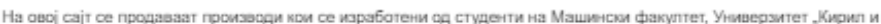

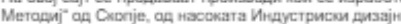

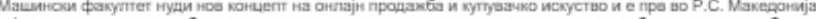

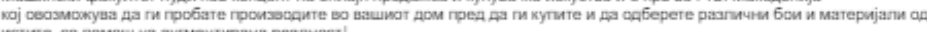
истите, со помош на аупентирана реanнoci

Уживаіте во мутувамето

KOHTAKT

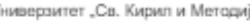

Машиніси фамултет - Crorie

Aupecas Kapnow II 66, 1000 Cxonie.

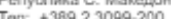

PAEOTHO BPEME

Пон- Пет: $09.00-22.00$

ПOBEKE ЗА МАШИНСКИ ФАКУЛTET, УКИM СKOחJE

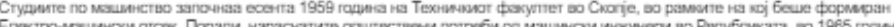

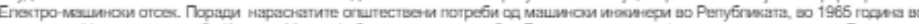

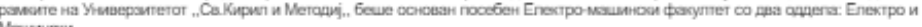

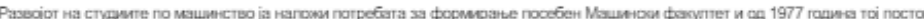

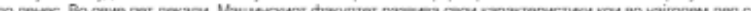

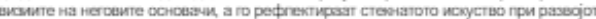

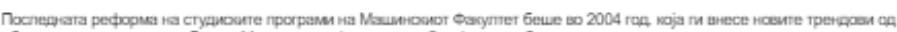

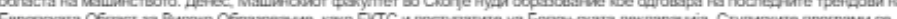

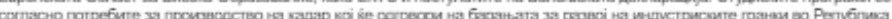

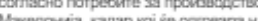

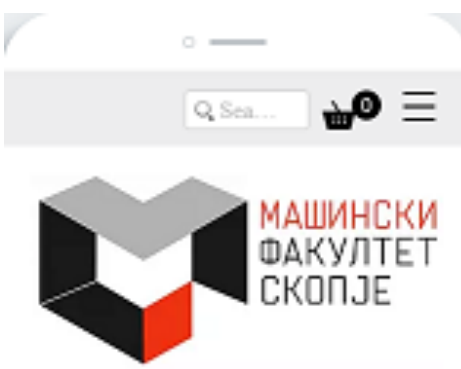

3 A H A C

Ha oвoj cajr ce nponasaar npoизводи кои се изрвботени од студенти на Машиюски факуттет, Уииеераитет Кирил и Методиј" or Сnonje, on насоката Июдустриски дизајн

Машмески фағултет муди ное концепт на онлајн продажбв и қутувачко искустео и е пре во P C Македонаја кој овозмохува да ғи пробате производите во ваแм⿰т дом пред да пи купите и да одберете ралпични бои и материіапи од истите, со помош на аугментирана реaпност!

Yжиеајте во кутуването!

\section{КОНTAKT}

\begin{tabular}{|c|c|c|}
\hline Phone & $\underset{E-\infty}{\square}$ & If \\
\hline
\end{tabular}

Слика 8- Приказ на десктоп и мобилната верзија на страната „За нас“ на веб-сајтот
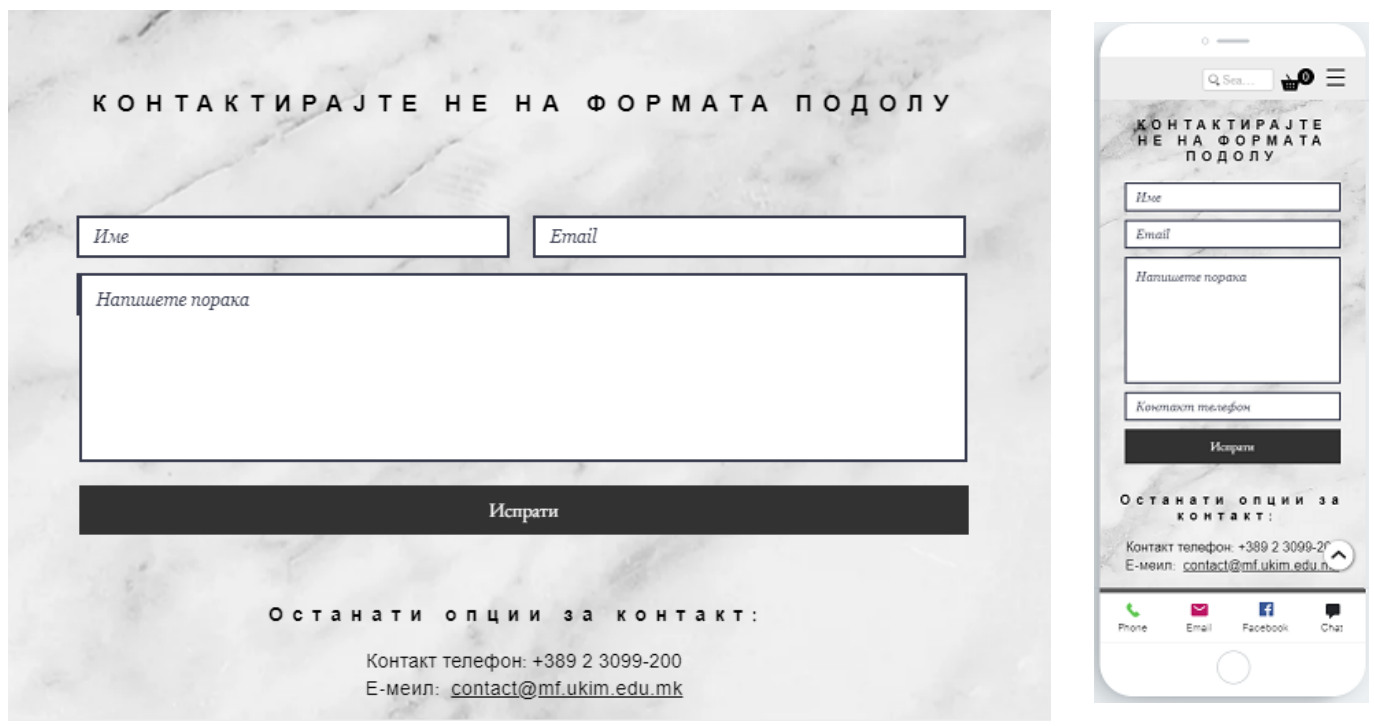

Слика 9 - Приказ на десктоп и мобилната верзија на страната „Контакт“ на веб-сајтот 